\title{
O DESENVOLVIMENTO DA LINGUAGEM ORAL DE CRIANÇAS NO CONTEXTO DE UMA CRECHE
}

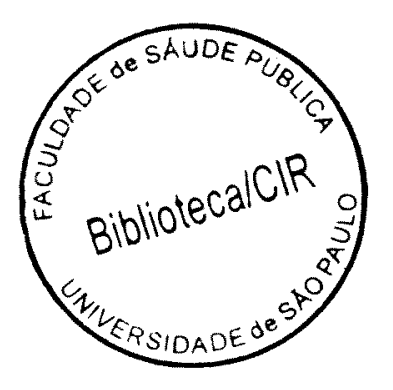

\section{ANDREA WANDER BONAMIGO}

Tese apresentada ao Departamento de Saúde Materno-Infantil, da Faculdade de Saúde Pública da Universidade de São Paulo, para a obtenção do título de Doutor em Saúde Pública.

Área de concentração: Saúde Materno-Infantil

Orientador: Dr. Cornélio Pedroso Rosenburg 
Autorizo, exclusivamente para fins acadêmicos e científicos, a reprodução total ou parcial desta tese, por processos fotocopiadores.

Dassinatura:

$40246 / 2000$ (doc) 
Arlindo e Dolores, pais amados, com seus exemplos de amor a tudo que fazem, pude crescer, me desenvolver $e$ me restaurar sempre que precisei. Suas expressões de afeto, de cuidado e de compreensão constituíram fontes de inspiração!

Alessandro, irmão querido, suas palavras de entusiasmo, incentivo e confiança foram determinantes e seu bem querer, conforto ao coração. 


\section{AGRADECIMENTOS}

Ao Prof. Dr. Cornélio Pedroso Rosenburg, exemplo inspirador de intelectual sensivel, sinceramente agradeço pela valiosa orientação, pelos momentos compartilhados, pelas profundas reflexões e subsídios que deixou nos nossos diálogos realizadores.

À Profa Dra Fumika Peres, do Departamento de Saúde MaternoInfantil da FSP-USP, pela atenção dispensada na leitura e pelas sugestões enriquecedoras na fase de finalização deste trabalho.

À Profa Dra Luiza de Arruda Nepomuceno, do Centro de Ciências Biológicas e da Saúde da UNG, meus agradecimentos pela carinhosa atenção, pela leitura e recomendações sugeridas. Deixo minha admiração, amizade e respeito pelo exemplo de pessoa e profissional competente.

À Profa Doris Ruthi Lewis, do Departamento dos Distúrbios da Comunicação da PUCSP, pelas prestimosas contribuições na complementação deste trabalho.

Ao Prof. Dr. Jorge Oishi pela cordialidade e incentivo.

À Profa Dra Keiko Ogura Buralli, pela colaboração e sugestões durante a fase de construção do projeto de pesquisa. 
Ao CNPq pela bolsa de estudo recebida para a realização dessa pesquisa.

À Margarida Maria Hoeppner Zaroni, por seu acolhimento sempre carinhoso nos momentos de reflexão sobre a metodologia estatística empregada.

Às crianças, familiares e auxiliares de desenvolvimento infantil do CADI Jd Elisa Maria, por compartilharem suas vidas e seu cotidiano, por tudo o que possibilitaram e por serem a razão deste estudo.

Aos funcionários do Departamento de Saúde Materno-Infantil, Elba Barreto Carvalho, lara A. de Macedo, Leandro Fermino Cleto, Nilson Silva Soares e Sónia M. Heto pela dedicação e atenção dispensada.

À Débora Elyodora Cantadeiro, pelo apoio na digitaçăo e edição final do trabalho. Indispensável colaboração.

Aos amigos, pela paciência, pela alegria, pelo estímulo, pela preocupação, mas, sobretudo pela emoção de sua convivência. 


\section{RESUMO}

Bonamigo, A. W. O Desenvolvimento da Linguagem Oral de crianças no contexto de uma creche, São Paulo; 2000. [Tese de Doutoramento Faculdade de Saúde Pública da USP].

A creche se apresenta como um espaço educativo onde as ações de promoção à saúde na área da Fonoaudiologia geram efeitos significativos sobre o desenvolvimento da linguagem oral de crianças.

Neste sentido realizou-se $\circ$ presente estudo com o objetivo de analisar as relações existentes entre o desenvolvimento da linguagem oral de crianças assistidas por auxiliares de desenvolvimento infantil previamente treinadas por uma fonoaudióloga e o tempo de acompanhamento no contexto de uma creche.

A descrição da linguagem nos aspectos da formulação de conceitos, do desenvolvimento fonêmico e da produção oral foi realizada em dois grupos de seis crianças com tempos distintos de acompanhamento, ou seja, seis meses ou menos e quatro anos.

Os resultados mostraram que as crianças com maior tempo de acompanhamento apresentaram melhores desempenhos nos temas de linguagem descritos. A metodologia de análise estatística, Análise de Correspondências Múltiplas, revelou que o desenvolvimento da linguagem está associado ao tempo de acompanhamento na creche. O gradiente do 
desenvolvimento da linguagem oral foi demonstrado e evidenciou a singularidade de desenvolvimento de cada criança.

As conclusões sugerem que o acompanhamento realizado pelas auxiliares de desenvolvimento infantil previamente treinadas e a circunstância dessa creche que oferece inúmeras oportunidades de interação contribuíram para a construção do desenvolvimento da linguagem oral das crianças atendidas.

Descritores: Creche. Desenvolvimento de Linguagem. Crianças. Metodologia Estatística Aplicada. Fonoaudiologia. Atenção Primária à Saúde. Formação de Educadores. 


\section{SUMMARY}

\section{Bonamigo, A. W. O Desenvolvimento da Linguagem Oral de Crianças no}

Contexto de uma Creche [The Development of Oral Language of Children in the Context of a Day-care center]. São Paulo (BR); 2000. [Tese de Doutorado Faculdade de Saúde Pública da Universidade de São Paulo].

The day-care center shows itself as an educational area where the actions to the promotion of health in the Speech and Language Therapy field generate significant effects on the development of oral language of children.

In this sense the present research was carried out with the objective of analyzing the existent relations between the development of oral language of children attended by child development assistants previously trained by a phonoaudiologyst and the period of accompaniment in the context of a day-care center.

The description of language in the aspects of concept formulation, of the phonemic development and of the oral production was carried out in two groups of six children with distinct accompaniment periods, in other words, six months or less and four years.

The results showed that the children with higher accompaniment time presented better performance on the language themes described. The 
methodology of statistics analysis, Analysis of Multiple Correspondencies, showed that the development of language is associated to the period of accompaniment in the day-care center. The gradient of the development of oral language was demonstrated and evidenced the singularity of development of each child.

The conclusions suggest that the accompaniment carried out by the child development assistants previously trained and the circumstance of this day-care center that offers various opportunities of interaction contributed to the construction of the development of oral language of the attended children.

Describers: Day-care center. Development of Language. Children. Methodology Applied Statistics. Speech and Language Therapy. Primary Care to Health. Formation of Educators. 


\section{ÍNDICE}

\section{Apresentação}

1. Introdução

1.1. A Linguagem Oral enquanto expressão do Desenvolvimento da Criança

1.2. O Contexto Creche e o Desenvolvimento da Criança

1.3. A Atuação Fonoaudiológica na Atenção Primária à Saúde

2. Objetivos

2.1. Objetivo Geral

2.2. Objetivos Especificos

\section{A Descrição da Linguagem Oral}

3.1. Delineamento da Pesquisa

3.2. População

3.3. Instrumento de Pesquisa e Coleta de Dados

3.4. Variáveis de Estudo

3.5. Desempenho de Crianças quanto à Descrição da Linguagem

3.6.1.2. Estudo da Associação entre os Temas de Linguagem de Crianças com Ingresso Recente na Creche (igual ou menor há 6 meses) e de Crianças com Quatro anos ou mais de acompanhamento 


\section{Resultados}

4.1.1. Desempenho Específico de Crianças dos Grupos $6 \mathrm{~m}$ e 4a segundo o Tema de Linguagem Formação de Conceitos

4.1.2. Desempenho Específico de Crianças dos Grupos $6 \mathrm{~m}$ e 4a segundo o Tema de Linguagem Desenvolvimento Fonêmico

4.1.3. Desempenho Especifico de Crianças dos Grupos $6 \mathrm{~m}$ e 4a segundo o Tema de Linguagem Produção de Narrativas Orais

4.1.4. Desempenho Geral de Crianças dos Grupos $6 \mathrm{~m}$ e $4 a$ segundo o Desenvolvimento da Linguagem

4.2. Estudo da Associação da Linguagem de Crianças com Ingresso Recente na Creche (igual ou menor há 6 meses) $e$ as Crianças com Quatro anos ou mais de Acompanhamento

4.2.1. Tipologia dos Temas de Linguagem

4.2.1.1. Descrição dos Eixos Principais

4.2.1.2. Definição dos Eixos Principais

4.2.1.2.1. Definição do Primeiro Eixo Principal (F1) 65

4.2.1.2.2. Definição do Segundo Eixo Principal (F2) 69

4.2.2. Tipologia das Crianças e de seus Desempenhos 70

4.2.2.1. Crianças com Ingresso Recente (igual ou menor há 6 meses)

4.2.2.2. Crianças com Quatro anos ou mais de Acompanhamento 73

4.2.2.3. Diferenciação do Tempo de Acompanhamento de 
5. Discussão 78

5.1. Caracteristicas Gerais $\quad 80$

5.1.1. Formação de Conceitos $\quad 80$

5.1.2. Desenvolvimento Fonêmico 83

5.1.3. Produção de Narrativas Orais 86

5.2. Estudo da Associação dos Temas de Linguagem
e o Tempo de Acompanhamento na Creche

6. Consideraçరెes Finais 92

7. Conclusőes 99

8. Referências Bibliográficas 101

Anexos

Anexo 1: A Creche - Contexto desse Estudo 1A

Anexo 2: A Proposta Psicopedagógica do Cadi 34 Jd. Elisa Maria

Anexo 3: Termo de Consentimento Esclarecido (ADI) 26A

Anexo 4: Roteiro para as Entrevistas com as ADI 28A

Anexo 5: Caracterização das Entrevistas 31A

Anexo 6: A Análise do Discurso de Auxiliares do Desenvolvimento Infantil

Anexo 7: Carta de Apresentação da Pesquisadora à Coordenadora das Creches

Anexo 8: Consentimento Esclarecido - Responsáveis pelas crianças selecionadas a participarem da Pesquisa $\quad 93 \mathrm{~A}$

Anexo 9: Instrumento para a Descrição da Linguagem Oral $\quad$ 95A 
Anexo 10: Figuras Integrantes das Estratégias Utilizadas para a Descrição da Linguagem Oral

Anexo 11: Protocolo de Registro dos achados da Descrição da Linguagem Oral

Anexo 12: Achados da Triagem Audiométrica e Imitanciométrica 115A

Anexo 13: Desempenho das Crianças submetidas à Descrição 117A dos Temas de Linguagem

Desempenho das Crianças submetidas à Descrição 118A dos Temas de Linguagem

Pontuação específica de cada variável no Grupo de Crianças de $6 \mathrm{~m}$

Pontuação específica de cada variável no Grupo de Crianças de $4 a$

Anexo 14: Fotos

CADI 34 Jd Elisa Maria - Visão do equipamento 122A

Atividades Educativas externas e internas 


\section{LISTA DE TABELAS}

Tabela 1. Descrição das Variáveis Transformadas em Modalidades Descritoras dos Temas de Linguagem formação de conceitos (cor, forma, esquema corporal, posição no espaço, tamanho, distância, quantidade, espessura, comprimento, igual-diferente e seqüência lógico temporal), desenvolvimento fonémico (descrição fonêmica e características da fala) e produção de narrativas orais $e$, dos grupos de crianças com ingresso recente na creche (igual ou menor há 6 meses) e crianças com 4 anos de acompanhamento, CADI 34, São Paulo, 1999.

Tabela 2. Distribuição das crianças segundo o tempo de acompanhamento na creche, o sexo e a idade, CADI 34, São Paulo, 1999.

Tabela 3. Inércias associadas, $\%$ inércia parcial, $\%$ inércia acumulada e primeiras diferenças.

Tabela 4. Códigos, coordenadas, inércias parciais e relativas nos dois primeiros eixos principais, segundo os Temas de Linguagem formação de conceitos (cor, forma, esquema corporal, posição no espaço, tamanho, distância, quantidade, espessura, altura, comprimento, igual-diferente e seqüência lógico temporal), desenvolvimento fonémico (descrição fonêmica e características de produção da fala) e produção de narrativas orais.

Tabela 5. Códigos, coordenadas, inércias parciais e relativas nos dois primeiros eixos principais das crianças, segundo os grupos com ingresso recente na creche (igual ou menor há 6 meses) e com 4 anos ou mais de acompanhamento.

Tabela 6. Desempenho das crianças submetidas à descrição da linguagem, São Paulo, 1999.

Tabela 7. Pontuação específica de cada variável no grupo de crianças de 6m, São Paulo, 1999.

Tabela 8. Pontuação específica de cada variável no grupo de crianças de 4a, São Paulo, 1999. 


\section{LISTA DE FIGURAS}

Figura 1. Desempenho específico segundo 0 tema de linguagem Formulação de Conceitos de crianças com 6 meses ou menos de acompanhamento na creche, CADI 34, São Paulo, 1999.

Figura 2. Desempenho específico segundo o tema de linguagem Formulação de Conceitos de crianças com 4 anos ou mais de acompanhamento na creche, CADI 34, São Paulo, 1999.

Figura 3. Desempenho específico de crianças com 6 meses ou menos de acompanhamento na creche segundo o tema de linguagem Desenvolvimento Fonêmico, CADI 34, São Paulo, 1999.

Figura 4. Desempenho especifico de crianças com 4 anos ou mais de acompanhamento na creche segundo 0 tema de linguagem Desenvolvimento Fonêmico, CADI 34, São Paulo, 1999.

Figura 5. Desempenho especifico de crianças com 6 meses ou menos de acompanhamento na creche segundo o tema de linguagem Produção de Narrativas Orais, CADI 34, São Paulo, 1999.

Figura 6. Desempenho especifico de crianças com 4 anos ou mais de acompanhamento na creche segundo o tema de linguagem Produção de Narrativas Orais, CADI 34, São Paulo, 1999.

Figura 7. Desenvolvimento geral de crianças com 6 meses ou menos de acompanhamento na creche segundo o Desenvolvimento da Linguagem, CADI 34, São Paulo, 1999.

Figura 8. Desempenho de crianças com 4 anos ou mais de acompanhamento na creche segundo o Desenvolvimento da Linguagem, CADI 34, São Paulo, 1999.

Figura 9. Média das porcentagens de percepção dos temas de linguagem dos grupos 6M e 4A, CADI 34, São Paulo, 1999 (1).

Figura 10. Definição parcial do eixo principal $F_{1}$ - Gradiente do Desenvolvimento da Linguagem.

Figura 11. Definição geral do eixo principal $F_{1}$ - Gradiente do Desenvolvimento da Linguagem $x$ Diferenciação do tempo de acompanhamento de crianças na creche. 


\section{LISTA DE GRÁFICOS}

Gráfico 1. (a) Plano fatorial $F_{1} \times F_{2}$; e, (b) Definição parcial do eixo principal $F_{1}$, segundo o desempenho na Formação de Conceitos.

Gráfico 2. Plano fatorial $F_{1} \times F_{2}$; e, (b) Definição parcial do eixo principal $F_{1}$, segundo o desempenho no Desenvolvimento Fonémico e na Produção de Narrativas Orais.

Gráfico 3. (a) Plano fatorial $F_{1} \times F_{2}$, segundo as coordenadas das crianças com 6 meses ou menos e, das crianças com 4 anos ou mais de acompanhamento na creche; e, (b) Definição parcial do eixo principal $F_{1}$ - Gradiente do Desenvolvimento da Linguagem $\times$ Diferenciação do tempo de acompanhamento de crianças na creche.

Gráfico 4. Plano Fatorial $F_{1} \times F_{2}$ - Formação de Conceitos, Desenvo/vimento Fonémico e Produção de Narrativas Orais associados à diferenciação do desenvolvimento da linguagem, segundo o tempo de acompanhamento de crianças na creche. 


\section{LISTA DE QUADROS}

Quadro 1. Representação da Escala de Percepção em Temas de Linguagem de crianças em diferentes tempos de acompanhamento na creche. 


\section{APRESENTAÇÃO}

Observamos em na nossa atuação que acompanhar o desenvolvimento de crianças é um desafio e uma prazerosa atividade.

Reconhecemos a linguagem oral como um dos aspectos importantes do desenvolvimento da criança na medida em que possibilita a comunicação intra e interpessoal.

A linguagem oral é uma das modalidades de comunicação que pode ser entendida como mediadora da interação da criança com a sua circunstância.

Escolhemos a circunstância da creche como local para realizar este estudo porque foi nosso local de trabalho e vem revelar e esclarecer indagações construidas ao longo de seis anos.

A creche CADI 34 Jd Elisa Maria foi escolhida por apresentar uma proposta diferenciada de atendimento às crianças. Constituída como um Centro de Acompanhamento do Desenvolvimento Infantil (CADI) não somente está preocupada em garantir a custódia, mas também promover uma atenção integral às crianças assistidas.

O CADI é uma creche destinada a proporcionar assistência, proteger e dar cuidados diurnos integrados por higiene, alimentação, educação, recreação e ações de promoção à saúde às crianças de 3 meses a 6 anos e 
11 meses, assistidas por auxiliares de desenvolvimento infantil (ADI), as quais são responsáveis pelo acompanhamento do desenvolvimento das crianças.

Apresentamos no ANEXO 1 uma minuciosa descrição da creche decorrente do diagnóstico institucional realizado com a finalidade de conhecer profundamente a realidade do contexto da pesquisa onde as crianças passam o maior tempo de sua infância.

$\mathrm{Na}$ trajetória de nossa vida, enfrentamos a tarefa intrigante de administrar uma creche que respondesse a uma proposta de atendimento que visasse o desenvolvimento integral da criança e evidenciasse a linguagem oral como um importante aspecto a ser observado.

Acreditamos que o convivio cotidiano das crianças com as ADI se manifesta como um dos elementos fundamentais para o desenvolvimento da linguagem oral, instrumento por meio do qual pode-se vivenciar e experimentar as possibilidades do nosso entorno.

Além do compromisso administrativo, nossa atuação nessa creche, enquanto fonoaudióloga, compreendia os primeiros contatos com os familiares na ocasião do ingresso dos filhos; o acompanhamento das crianças em seu período de adaptação; assessoramento na elaboraçāo do planejamento psicopedagógico na área da linguagem; organização de treinamentos e palestras; planejamento de programas de estimulação e desenvolvimento e, acompanhamento e orientação de ADI no desenvolvimento do seu trabalho cotidiano junto às crianças. 
O planejamento psicopedagógico desenvolvido nesta creche revela que as situaçōes dialógicas são privilegiadas como pressuposto para a realização das atividades sugeridas. Dá-se importância para a estimulação do desenvolvimento integral das crianças, considerando a linguagem oral como expressão desse desenvolvimento. No ANEXO 2 esse planejamento está apresentado.

As auxiliares de desenvolvimento infantil dessa creche passaram por um treinamento na ocasião do seu ingresso.

$\mathrm{Na}$ área da Fonoaudiologia foram enfocados temas como a importância das funções neurovegetativas (a sucção e a mastigação) para o desenvolvimento da fala; o desenvolvimento da função auditiva; o desenvolvimento da linguagem (aspectos cognitivos e lingüísticos); o desenvolvimento da função simbólica (o jogo infantil); os hábitos orais; a abordagem educativa da alimentação; as caracteristicas do desenvolvimento neuropsicomotor nas diversas faixas etárias e a construção de brinquedos e jogos para a estimulação da linguagem.

A partir desse treinamento encontros mensais vêm sendo realizados, os quais estão previstos na programação anual da creche. A equipe técnica e as ADI participam desses encontros. Essas reuniōes têm o propósito de fornecer às ADI subsídios teórico-práticos, assim como reconhecer e avaliar as conquistas e dificuldades na atenção cotidiana às crianças.

Pensamos que auxiliares de desenvolvimento infantil, previamente treinadas atuariam como facilitadoras do desenvolvimento das crianças. Entretanto, ao se pensar no desenvolvimento da linguagem oral, em 
particular, ficava a indagação: em que condições estariam favorecendo esse desenvolvimento?

No intento de responder a esta questão, realizamos como atividade preliminar ao desenvolvimento desta pesquisa, o reconhecimento do desempenho das ADI treinadas no seu cotidiano de atendimento às crianças. Para tanto, utilizamos como estratégia, o registro do dia-a-dia na creche, por meio do uso da videogravação e entrevista.

A utilização do recurso da videogravação objetivou assinalar o cotidiano das crianças atendidas na interação com as ADI nos momentos de higiene, alimentação e recreação.

Treze auxiliares de desenvolvimento infantil foram entrevistadas, as quais tinham como caracteristicas o tempo de trabalho de no mínimo quatro anos com envolvimento nas atividades promovidas nessa creche e a manifestação de seu consentimento voluntário e livre à participação da pesquisa (ANEXO 3). A entrevista seguiu um roteiro norteador (ANEXO 4). No ANEXO 5 descrevemos quem são essas ADI previamente treinadas.

No trabalho de compreensão do material discursivo obtido, empregamos o dispositivo teórico e analítico desenvolvido pela análise de conteúdo, por meio da qual identificamos o que pensam as ADI sobre as crianças com as quais trabalham, a sua formação e o seu trabalho nesta creche, bem como os significados que atribuem à interação adulto-criança no contexto do desenvolvimento da criança e à linguagem oral enquanto expressão desse desenvolvimento. A leitura integral da análise do discurso das ADI é apresentada no ANEXO 6 
Essa investigação introdutória se fez necessária, uma vez que se desvelou como condição à descrição da linguagem oral de crianças com tempos diversos de acompanhamento nesta creche.

O presente estudo constitui uma tentativa para contribuir e esclarecer as indagações contidas nessa apresentação e revelar possiveis caminhos que facilitem e aperfeiçoem a atuação das ADI no acompanhamento do desenvolvimento da criança. Da mesma forma propōe-se fornecer subsidio para repensar a atuação da Fonoaudiologia em instituições infantis, apresentando-as como espaço para a realização de ações de promoção e prevenção, com vistas a apoiar crianças em seu processo de desenvolvimento integral.

Estabelecemos como objetivos dessa pesquisa, analisar as relaçōes existentes entre o desenvolvimento da linguagem oral de crianças de 4 anos e 1 mês a 5 anos e 4 meses assistidas por auxiliares de desenvolvimento infantil e o tempo de acompanhamento no contexto de uma creche.

Pensando nesses propósitos empenhamo-nos na busca de uma metodologia estatística que melhor pudesse ser aplicada à intenção de verificar a diversidade das variáveis abrangidas em cada tema de linguagem oral observado.

Consideramos esta creche como um espaço potencialmente educativo, onde a criança vive a maior parte do seu tempo, influenciando, sendo influenciada e modificando o seu desenvolvimento.

Este trabalho apresenta em sua introdução (primeiro capítulo) a revisão da literatura, ou seja, subsidios teóricos, agrupados em três grandes 
temas: a linguagem oral enquanto expressão do desenvolvimento da criança, o contexto creche e o desenvolvimento e a atuação da Fonoaudiologia na atenção primária à saúde.

No segundo capitulo apresentamos os objetivos da pesquisa.

No terceiro capítulo apresentamos os sujeitos participantes, as estratégias utilizadas para a descrição do uso funcional da linguagem, a coleta de dados e a análise dos dados.

Os resultados obtidos na descrição da linguagem oral de crianças com tempos diversos de acompanhamento nesta creche estão contidos no quarto capitulo.

Nossas discussões acerca dos resultados da descrição da linguagem oral das crianças assistidas por auxiliares de desenvolvimento infantil, previamente treinadas, no contexto dessa creche estão apresentadas no quinto capítulo.

Tecemos no sexto capítulo, nossas consideraçōes gerais, entendendo que com o surgimento das ações preventivas o contexto creche se revela um lugar privilegiado para a promoção do desenvolvimento da linguagem oral e para a atuação da Fonoaudiologia.

Finalizando nosso estudo, apresentamos as conclusões gerais da pesquisa no sétimo capitulo. 
1. INTRODUÇÃO 


\subsection{A LINGUAGEM ORAL ENQUANTO EXPRESSÃO DO DESENVOLVIMENTO DA CRIANÇA}

Apresentamos, neste momento, breves considerações sobre o desenvolvimento da linguagem.

O referencial teórico dessa pesquisa encontra sustentação cientifica na teoria sócio-interacionista que postula o desenvolvimento da criança como decorrente da qualidade de relações que esta tem com o mundo que em que vive.

O ato humano de crescer e desenvolver em cada individuo, criança ou adulto, existe, em determinado espaço e tempo, num preciso momento geográfico, histórico, social, afetivo e cultural.

Com base na concepção sócio-interacionista, identificamos que 0 desenvolvimento humano ocorre nas e por meio das inúmeras interações que as crianças estabelecem, desde muito cedo, com a sua circunstância e sua abrangência. Elas atuam nas interações não como sujeitos passivos, simplesmente moldadas pelo meio, mas como seres ativos em processo de autoconstrução (ORTEGA Y GASSET, 1989; VIGOTSKY, 1989; OLIVEIRA et al, 1992; SEBER, LUíS, 1995).

A criança experimenta avanços e retrocessos vivendo seu desenvolvimento de modo intransferivel e particular (VIGOTSKY, 1989). 
As atuações da criança na interação com sua circunstância revelam a possibilidade de ser influenciada por ela e também agir sobre ela, transformando-a, re-significando-a, numa construção mútua carregada de afetividade (WALLON, 1966; ORTEGA Y GASSET, 1989). Tais atuações são realizadas por meio de vivências individuais e coletivas, nas quais o desafio de converter situações desprazerosas em prazerosas se alterna constantemente.

Nessa perspectiva assinalamos a importância que tem para a criança a parceria com o adulto e com outras crianças nos mais diversos ambientes - família, creches, escolas, parques etc - no percurso das descobertas do que está à sua volta. As relações interpessoais ocupam um lugar privilegiado nas trocas da criança com a sua circunstância por se constituirem em fonte, continente e alvo de toda gama de afetos e sentimentos, como o amor, a alegria, o ciúme, a dúvida, a tristeza, a insegurança, entre outros.

A criança envolvida por linguagens, desde o seu nascimento, amplia qualitativamente as suas relações com a realidade física e social com o aparecimento da oralidade (VIGOTSKY, 1989; SOUZA, 1995). Salientamos ainda o valor essencial do instrumento da linguagem oral como a expressão mais pura de interação social.

Concebemos a linguagem, a partir dos registros de HALLIDAY (1975) e SMOLKA (1995), como interação humana e atividade constitutiva do sujeito, assumindo assim a sua natureza funcional, interativa, social e integrativa. 
A criança transpõe fases evolutivas que vão se sucedendo conforme vai crescendo e se desenvolvendo. A construção de cada fase é distinta das anteriores e o essencial das experiências sucessivas permanece no decorrer das fases posteriores (PIAGET, 1976). A passagem de um periodo para o outro segue uma mesma regularidade para todas as crianças, mas não num mesmo ritmo (LA PIERRE, AUCOUTURIE, 1986).

A criança faz um enorme progresso cognitivo utilizando basicamente as suas sensaçōes e percepçōes sensoriais no início de sua vida. Para ela é como se tratasse de conhecer e compreender a realidade por meio de seu uso, sugando, mordendo, tocando, balançando e jogando.

Nessa primeira fase, as condições biológicas, características anátomo-físico-neurológicas específicas, as vivências sociais e afetivas da criança permitirão a elaboração de sua organização básica psicológica e cognitiva, seja no aspecto motor, perceptivo, social e intelectual. Para tanto necessitarão de um espaço e de possibilidades que apresentem sons, cores, luzes e formas concretas variadas.

$\mathrm{Na}$ conquista das palavras e de sua utilização, com o aprendizado da língua materna, a criança dará um dos passos mais importantes do seu desenvolvimento.

No decorrer do primeiro ano de vida, a criança aprende gradualmente a identificar, reconhecer e discriminar os sons e a formação das palavras, para experimentá-las como entidades autônomas no segundo ano (PIAGET, 1976; LA PIERRE, AUCOUTIER, 1986). 
As palavras constituem fonte de prazer para as crianças, não só pela possibilidade de articulá-las como também pela audição da melodia de sua entonação.

A produção adequada dos fonemas da fala requer da criança uma coordenação precisa das estruturas orgânicas e funcionais envolvidas primeiramente na respiração, sucção, deglutição, mastigação e fonação (PEREIRA et al, 1995).

KÖNIG (1987) entende que as crianças, quando empregam as palavras como "portas e janelas" na interação com a sua circunstância, Olham para dentro do mundo das idéias.

Com a utilização do código lingüístico para se comunicar, elas se tornam capazes de revelar e manifestar suas ações, sentimentos e pensamentos sob forma de narrativas pela representação oral (FARIA, 1994; GUEDES, 1995).

A apropriação da linguagem pela criança, à luz da concepção sóciointeracionista, é abordada por alguns estudos (PIAGET, 1976; HALLIDAY, 1975; HAGE, 1995; GUEDES, 1995; VIGOSTKY, 1996, CORDEIRO, 1998) como integrante de um processo sócio-semiótico. Os autores descrevem a continuidade funcional e estrutural da passagem da comunicação pré-verbal para a comunicação verbal. Durante o desenvolvimento da linguagem ocorre uma ação reciproca entre o processo lingüistico e o social. A criança, enquanto assimila um sistema semiótico por meio de outro sistema funcional, a linguagem, é capaz de aprender a decodificar o processo sóciocultural. 
Nesse sentido, complementa CORDEIRO (1998:68):

"Pouco a pouco, a criança, sob o efeito permanente de sua interação com um mundo sócio-lingüisticamente organizado, vai substituindo suas representações idiossincráticas por unidades lingüísticas pertencentes a uma língua determinada, utilizando-as como instrumentos de conhecimento privilegiados, o que the permite uma contínua re-construção das representações, agora racionais, dos mundos objetivo, social e subjetivo."

Portanto, depreendemos que a fala revela o ser, não apenas a criança na sua dimensão psicobiológica, como também é capaz de caracterizá-la na sua formação sócio-cultural. Na interação adulto-criança fica evidente que as influências sócio-culturais interferirão de forma significativa quanto maior for a integração da criança na sociedade (VIGOTSKY, 1989; GUEDES, 1995; TAMANAHA et al, 1999).

Os trabalhos desenvolvidos por ARANTES (1994) e por FREIRE (1994) tiveram como objeto de estudo a comunicação oral. Em seus trabalhos foram enfatizados os aspectos da interlocução, como processo responsável pelo desenvolvimento da linguagem da criança, concedendo ao adulto o papel de co-autor dessa linguagem.

Nesta linha de pensamento, as atribuições de sentido dadas pelo adulto aos comportamentos da criança são observadas como atitudes relevantes para que a linguagem se constitua na criança (LIER, 1983). 
As crianças, quando estimuladas pelos adultos, vão interagir não só com os objetos, mas também com uma variedade de condições, ações e circunstâncias sociais, reconhecendo-os, entendendo-os e incorporando-os por meio de sua linguagem (QUIRÓS, GUELER, 1966; VIGOTSKY, 1989; MACHADO, 1994).

Os adultos responsáveis pelo acompanhamento de crianças, nessa perspectiva, planejam atividades e organizam ambientes, conforme as representaçōes e expectativas que têm sobre elas, sobre 0 seu desenvolvimento e sobre o seu próprio papel em relação a ela. 


\subsection{O CONTEXTO CRECHE E O DESENVOLVIMENTO DA}

\section{CRIANÇA}

Para reconhecer as diferentes funções que a creche vem incorporando no atendimento à criança desde os seus primórdios é necessário recorrermos ao processo histórico.

A creche filantrópica surge no século XVI apresentando um caráter leigo de atendimento. Não exigia um papel profissional de quem nela trabalhava, mas um corpo voluntário que devia cuidar das crianças para que estas sobrevivessem e não se marginalizassem. Destacou-se, nesse periodo, a assistência reduzida e precária em nome da caridade, realizada por instituições não-governamentais (KISHIMOTO, 1988; MERISSE, 1997).

A creche higienista, durante o século $X I X$ e início do século $X X$, preocupou-se em minimizar a morbidade e mortalidade infantis. Para tanto, propôs um papel profissional de caráter técnico, asséptico e sem preocupação com os aspectos afetivos e sociais no atendimento às crianças (MERISSE, 1997).

A creche substituta, doméstica, surge somente neste século, como uma reivindicação da mulher trabalhadora que não tinha onde deixar os filhos. O profissional devia cuidar da saúde física e emocional da criança como uma mãe o faria. O Estado e as instituições filantrópicas foram os responsáveis pela manutenção do serviço de custódia, alimentação e higiene (GALLARDO, 1993). 
A creche compensatória surge com o objetivo de sanar as carências nutricionais e culturais das crianças atendidas. Tais intenções apareceram do pensamento que "a suposta carência da criança conduziria a uma inaptidão generalizada, lingüística, motora e social" (MERISSE, 1997:46). Portanto, o profissional dessa creche desenvolvia a função de recreacionista com a finalidade de preparar as crianças para a escolaridade. Dessa concepção, reconheceram-se os primeiros esforços dos órgãos oficiais em expandir o sistema de educação às crianças menores de 6 anos de idade (MERISSE, 1997).

A Constituição de 1988, pela primeira vez no Brasil, consolidou as creches e as pré-escolas como espaços educativos, cujo atendimento configurou-se como dever do Estado e direito das crianças de zero a seis anos de idade, consagrando, no plano da lei, o que os movimentos sociais já vinham reivindicando em várias partes do país (CAMPOS, ROSEMBERG, 1995).

Durante muito tempo as creches de todo o mundo, incluindo as brasileiras, organizaram os seus espaços e o seu cotidiano em função das idẻias de assistência, de custódia e de higiene.

As atividades desenvolvidas se propunham a prevenir a marginalização das crianças, uma vez que as tiravam das ruas, a combater a pobreza e a mortalidade infantil e a substituir as mães, exercendo o seu papel melhor do que elas o fariam (PICOLO, 1983; ROSSETTI-FERREIRA et al, 1994). 
A procura por creches e pré-escolas até o presente é fenômeno comum a diversos paises. Vários fatores podem ter contribuído para a valorização e expansão dessas instituições, entre os quais destacam-se a participação crescente da mulher na força de trabalho extradomiciliar, o avanço do conhecimento cientifico sobre o desenvolvimento da criança em seus primeiros anos de vida, a consciência social do significado da infância e o reconhecimento dos direitos da criança por parte da sociedade (HADDAD, 1993).

Nesse sentido, a assistência e o desenvolvimento da atenção integral da faixa etária de zero a seis anos de idade pode ter um significado particularmente importante, quando se fundamenta numa concepção de criança como cidadã, como pessoa em processo de desenvolvimento e como sujeito ativo da construção de sua vida (POLÍTICA NACIONAL DE EDUCAÇĀO INFANTIL, 1994).

Complementando os registros oficiais citados na Constituição de 88 , reconhecemos que as açōes de educação no atendimento à criança na creche deverão ser articuladas com as ações de saúde e de assistência (ROSSETTI-FERREIRA et al, 1994).

O reconhecimento da creche como um ambiente diferente da familia é relativamente recente. Considerando-a como um local de atendimento integral à criança, requer pessoas que exerçam funçōes especificas, capazes de responder à proposta de serem agentes de promoção do desenvolvimento (GALLARDO, 1993; OLIVEIRA, 1994). 
Dessa maneira os papéis na creche vêm sendo construidos, incorporando aspectos das funçōes desempenhadas no passado em cada momento histórico

As atribuições para o trabalho dar-se-ão de acordo com as necessidades sociais que compõem uma ou outra função, as quais introjetarão concepções relativas à criança, à familia e à própria creche.

São importantes as características pessoais, a formação e o conhecimento que alicerçam as vivências e as experiências individuais, para se compreender e definir o papel do adulto nessa nova concepção de creche (LEITE DE MORAIS, 1997).

No Brasil, a Lei 10.430 de 1988 (PROPOSTA PEDAGÓGICA, 1996) regulamentou a estrutura de cargos das creches e reenquadrou os funcionários que trabalham diretamente com as crianças como auxiliares de desenvolvimento infantil (ADI) legitimando as suas funções. São atribuições das ADI:

- participar da elaboração dos planejamentos da creche;

- executar atividades de estimulação com a utilização de materiais psicopedagógicos;

- controlar e registrar a freqüência diária das crianças;

- acompanhar e registrar o desenvolvimento integral da criança por meio de material padronizado pelas normas técnicas do CADI;

- realizar a triagem diária no horário de entrada;

- realizar e acompanhar a higiene pessoal e a alimentação; 
- acompanhar a saida, zelar e responsabilizar-se pela integridade das crianças do seu grupo de trabalho (SES, 1992).

Quando a criança ingressa na creche, traz consigo sua história individual, que pode influenciar de várias maneiras a sua adaptação. A história de cuidado, os vínculos e a qualidade de apego que estabeleceu, as variáveis como idade e sexo, as caracteristicas do seu desenvolvimento afetam direta ou indiretamente o modo pelo qual a criança se engaja em atividades, estrutura o seu ambiente e estabelece relações. (LORDÉLO, 1995).

A substituição do espaço domiciliar por um novo ambiente favorece o estabelecimento de novas relações e o fim da exclusividade dos cuidados realizados unicamente por um familiar.

A assistência às crianças nesse contexto é realizada pelas $A D I$, as quais devem conhecer as particularidades do desenvolvimento da criança e as características de sua família para respeitá-las, valorizá-las e saudavelmente com elas conviver. (ROSSETTI-FERREIRA et. al, 1994).

Alguns trabalhos investigaram os papéis desempenhados pelas ADI no convívio com as crianças no contexto creche. (OLIVEIRA, ROSSETTIFERREIRA, 1989; GEIS, 1994; LORDÉLO, 1995).

As conclusões desses estudos evidenciaram que a maioria das ADI exerciam suas funções sob a influência de conceitos internalizados em experiência de vida, sobre os cuidados com os próprios filhos, e sobre o seu 
papel de educadoras. Esses estudos revelaram ainda que as $A D I$ foram animadas pelas informações recebidas em sua instrução formal e da formação obtida em serviço.

Observamos que as múltiplas interaçōes presentes no cotidiano da creche fornecem condições que favorecem a promoção do desenvolvimento integral da criança e por isso devem ser traduzidas em atividades diárias (SAMPAIO, 1984; AUGUSTO, 1985; OLIVEIRA, ROSSETTI-FERREIRA, 1989).

As brincadeiras propostas e realizadas, por exemplo, podem ser consideradas como porta de entrada para que as crianças se interrelacionem com o mundo à sua volta.

Consideramos que a circunstância da creche é um dos aspectos que influencia poderosamente, seja positiva ou negativamente, sobre o desenvolvimento da linguagem oral (CAMPOS DE CARVALHO, RUBIANO, 1994).

Nesse sentido, LAUNAY, BOREL MAISONNY (1979), em um estudo realizado, consideraram a creche como um ambiente estimulante para favorecer o desenvolvimento da linguagem oral, mas ao mesmo tempo consideraram que, na maioria das creches investigadas, as crianças apresentaram um atraso de aquisição da linguagem, devido à organização de um ambiente desfavorável e às atitudes pouco estimuladoras das ADI.

Diante dessas evidências, reconhecemos que as caracteristicas peculiares da creche, a organização do espaço, o planejamento do cotidiano, a preparação de atividades, a atuação das ADI apresentam 
relações com o processo de aquisição da linguagem oral, instrumento dos mais importantes pelo qual a criança interage com a sua circunstância.

Nessa perspectiva, por meio da linguagem oral, a criança apropria-se ativamente das situações que aparecem no seu cotidiano (GAYOTTO e col. 1992; ZORZI, 1995; ABRAMOWICZ, WAJSKOP, 1995).

Portanto, parece-nos essencial que as ADI estruturem os espaços e organizem atividades que propiciem o desenvolvimento da linguagem oral.

$\mathrm{O}$ atendimento especializado e orientado, o ambiente estimulador e propício, o convívio das crianças com as ADI contribuirão sensivelmente para que as crianças se tornem sujeitos ativos na construção de sua vida (CAMPOS, ROSEMBERG, 1995).

Por fim, entendemos que a creche deve ser um espaço educativo que oferece um contexto coletivo especialmente planejado para favorecer o desenvolvimento da criança, em particular, no aspecto da linguagem oral. 


\subsection{A ATUAÇÃO FONOAUDIOLÓGICA NA ATENÇÃO PRIMÁRIA}

\section{À SAÚDE}

Objetivando apresentar as perspectivas da atuação fonoaudiológica na atenção primária à saúde, inicialmente resgataremos a organização e as características das Redes de Serviço de Saúde.

Os critérios de regionalização e os princípios de hierarquização, descentralização e desconcentração de atividades e funçōes são orientadores da organização das Redes de Serviços de Saúde. Nestes Equipamentos de Atenção à Saúde a prestação de serviços à população está sistematizada em niveis de complexidade que devem ser coordenados entre si e orientados para melhor aproveitamento dos recursos humanos e materiais, visando uma maior abrangência dessa atuação.

No sistema nacional de saúde as Unidades Básicas de Saúde (UBS) compõem o nivel de atenção primária à saúde, configurando-se como porta de entrada do sistema, destinadas a prover atendimentos ambulatoriais e desenvolver ações de saúde pública relativas às necessidades da população nas quais se inscrevem.

O discurso oficial (BRASIL, 1982) prevê que as UBS deverão planejar ações dirigidas ao individuo, à família e ao meio. Contempla como caracteristicas: 
- Apresentam-se como estabelecimentos de saúde da rede oficial que tem autoridade e responsabilidade legais, podendo aplicar a legislação sanitária em vigor.

- Estabelecem prioridades, a partir de um diagnóstico de saúde de sua área de atuação, utilizando critérios baseados na relação existente entre necessidade de saúde e recursos disponiveis.

- Atuam em uma área geográfica determinada.

- Dão ênfase às atividades de promoção e proteção da saúde da população.

- Aplicam as técnicas preventivas e curativas ao maior número de pessoas, com o uso de tecnologia apropriada e disponivel.

- Têm caráter dinâmico, desenvolvendo suas programações na comunidade, através de uma ação conjunta e permanente entre profissionais de saúde e população, na busca de soluções para a situação de saúde identificada.

- Abordam a problemática saúde/doença do individuo, da família e da comunidade em seus aspectos biopsicossociais.

- Têm a familia como foco básico de atuação.

- Desenvolvem suas ações por meio do trabalho em equipe multidisciplinar com a participação da comunidade.

- Desenvolvem atividades de saúde fora de seu âmbito físico com outros recursos da comunidade (escolas, creches, fábricas, associações de moradores, entre outros). 
- Articulam-se com outras instituições de Serviços de Saúde para assegurar o sistema de referência e contra-referência, assim como o desenvolvimento efetivo da ação do Setor Saúde.

- Dão ênfase às atividades educativas dirigidas aos individuos, familias, grupos e à comunidade, estimulando-os para a participação progressiva nas decisões e ações referentes ao Sistema de Saúde.

- Desenvolvem açōes sobre o meio ambiente, visando introduzir modificações que levem à promoção e proteção da saúde da comunidade.

- Desenvolvem ações de vigilância sanitária.

- Procuram programar suas atividades com base em critérios epidemiológicos.

- Avaliam suas atividades em função dos resultados obtidos em termos de produção de serviços e de mudanças nos niveis de saúde da comunidade e, também, segundo critérios de maior rendimento dos recursos disponiveis.

As instituições de saúde, portanto, necessitam conhecer a área sob sua responsabilidade para a definição das ações a serem desenvolvidas, a fim de proporcionarem um acompanhamento e uma intervenção na evolução dos fenômenos biológicos, mentais e sociais que nela ocorram.

A partir da reestruturação do sistema de saúde no país, abriu-se oportunidade da lotação de fonoaudiólogos em Unidades Básica de Saúde por meio de concursos públicos, iniciando-se ai a inserção da atuação desses profissionais na atenção primária à saúde. 
Recentemente, a participação da Fonoaudiologia na atenção primária à saúde dá-se, também, por meio de serviços de extensão prestados por universidades, estendendo suas açōes primárias aos equipamentos da comunidade.

BITTAR (1997:101) apresenta o desafio que envolve a inserção da Fonoaudiologia nas equipes de UBS, a saber:

“... engajar-se no grupo de profissionais de uma instituição exigirá, portanto, identificação das expectativas em relação ao trabalho fonoaudiológico, clareza de objetivos do trabalho proposto, definição de seu papel e conhecimento profundo do contexto pregresso e atual de trabalho do equipamento".

Assim sendo, a atuação fonoaudiológica requer uma formação profissional abrangente, que habilite o fonoaudiólogo a lidar de modo eficaz com elementos da esfera familiar, comunitária e social.

A participação dos fonoaudiólogos nas equipes em UBS pressupõe, ao lado de seu trabalho no nivel curativo e preventivo, promover a saúde na esfera sócio-cultural, possibilitando ao indivíduo a realização educacional em sua total potencialidade (VIEIRA, 1984).

As possibilidades de trabalho para os fonoaudiólogos na atenção primária são inúmeras, no que se refere à promoção de saúde e prevenção dos distúrbios da comunicação. A concretização dessas possibilidades, 
segundo BEFI (1997), provavelmente minimizaria o atendimento especifico da reabilitação fonoaudiológica.

Nesse sentido, compreendemos que a divulgação e a orientação sobre o desenvolvimento da linguagem, da fala, das funções motoras orais, da função auditiva estão contidas na atuação da Fonoaudiologia na atenção primária à saúde.

Com essas considerações é possivel estar reconhecendo como espaço de atuação de fonoaudiólogos no nivel da atenção primária, tanto o desenvolvimento de ações de promoção de saúde, assim como de outras voltadas à prevenção e deteç̧ão precoce de distúrbios da comunicação e correspondentes tratamentos.

ANDRADE (1996:39-40) aponta recomendações sobre a realizaçăo de procedimentos fonoaudiológicos preventivos, quando discorre sobre a prática da fonoaudiologia na saúde pública:

"... os programas preventivos, para que sejam eficientes e amplos, devem basear-se no desenvolvimento de modelos organizacionais do trabalho fonoaudiológico, selecionados a partir de um diagnóstico populacional. Esse diagnóstico da população determinará as reais condições para a elaboração e implantação desses programas específicos de saúde fonoaudiológica. Outro elemento determinante para a eficiéncia e amplitude dessas ações será a necessidade da existência de um sistema de referéncia e contra-referéncia para os serviços de fonoaudiologia. A estruturação desse 
sistema permitirá a prática fonoaudiológica em ações integradas e articuladas programaticamente".

Pensamos, portanto, que a aproximação do discurso oficial quando organizamos e programamos as ações em saúde fonoaudiológica na atenção primária à saúde tende a viabilizar as estratégias de atuação.

As UBS devem constituir-se a instância centralizadora e coordenadora das ações primárias e coletivas de saúde em equipamentos da comunidade (creches, pré-escolas, escolas, associações de bairros, entre outros), os quais passam a ser campos de atuação dos profissionais que naquelas trabalham (SUCUPIRA, 1994; LAGROTTA, CÉSAR, 1995).

Assim pensando, inscrevemos a creche como campo de atuação do fonoaudiólogo, na qual o profissional atua de forma integrada com todos os envolvidos: crianças, auxiliares de desenvolvimento infantil, familiares, funcionários e comunidade.

É importante lembrar que data da década de 80 que os fonoaudiólogos vêem-se cada vez mais interessados nas alterações de comunicação que surgem entre escolares e pré-escolares. Vislumbra-se dessa maneira, uma nova forma de ver o coletivo e não só o individual, a prevenção e a promoção e não exclusivamente a cura, levando em consideração as necessidades das diferentes populações.

Esse momento é apontado por CAPPELLETTI (1985), como a tomada de consciência dos fonoaudiólogos, na qual a responsabilidade social no atendimento à população em geral é assumida. 
Desde então, autores desenvolveram estudos com escolares e préescolares com o propósito de identificar e caracterizar o desenvolvimento da linguagem e detectar precocemente os distúrbios da comunicação (ROCHA, 1976; VASCONCELOS et al, 1982; COLLAÇO, 1991; PINTO et al, 1991; BITTAR et al, 1997; IORIO, 1999).

Consideramos fundamental a atuação da Fonoaudiologia no acompanhamento de crianças até os seis anos de vida, em função das rápidas e significativas transformações que ocorrem em vários aspectos do desenvolvimento.

Na cidade de São Paulo, as práticas voltadas à promoção e a prevenção têm surgido como alternativas importantes e a creche passa a ser um local privilegiado de trabalho do fonoaudiólogo, por ser esta a instituição social e educativa que atende a grande parcela de crianças até os seis anos de idade.

Um distúrbio de comunicação e/ou audição contribui para o aumento das dificuldades de aprendizado de uma criança em desenvolvimento. Estes distúrbios, quando detectados precocemente em creches e pré-escolas, possibilitam a intervenção e orientam a prática de auxiliares do desenvolvimento infantil, pais e professores no acompanhamento do processo de aprendizagem (PEREIRA et al, 1995).

A atuação da fonoaudiologia preventiva em crianças de creches e pré-escolas tem um papel importante no sentido de oferecer subsídios para o atendimento de crianças que manifestam ou não desvios ou distúrbios de comunicação para que ao ingressarem na primeira séria tenham 
oportunidades e perspectivas melhores de aprendizagem (CÉSAR, MORSELLI, SILVA, 1995).

Relacionamos, a seguir, alguns objetivos e atividades consideradas importantes para o planejamento do trabalho fonoaudiológico voltado a crianças de zero a seis anos de idade:

- proporcionar um conhecimento mais profundo dos aspectos relativos à linguagem, à fala e à audição;

- orientar atitudes e procedimentos que favoreçam o equilíbrio entre a fala, respiração e alimentação;

- orientar e assessorar a realização de trabalhos lúdicos para o desenvolvimento adequado da motricidade oral;

- propor atividades cotidianas que favoreçam o desenvolvimento da linguagem oral;

- sugerir soluções para prevenir hábitos orais inadequados.

Com base nessas colocações, julgamos de grande importância a sensibilização e a capacitação de auxiliares do desenvolvimento infantil, no sentido de garantir a manutenção dessas propostas nas atividades diárias junto às crianças assistidas, a partir da compreensão do desenvolvimento global de crianças, suas características e transtornos, assim como do conhecimento dos recursos diagnósticos disponíveis, tanto para fins de 
prevenção como de encaminhamento e correção (PEREIRA et al, 1995; HUBIG, SCHOCHAT, 1997).

É nessa visão que as creches constituem ambiente privilegiado para o atendimento primário em Fonoaudiologia. O número de crianças assistidas por entidades educacionais públicas leva-nos a crer no enorme potencial de divulgação de conhecimentos que geralmente não são explorados para fins educacionais.

Além disso, há que considerar que profissionais que trabalham junto a essas crianças, como as auxiliares de desenvolvimento infantil, também fazem parte da população beneficiária, principalmente considerando o papel que elas desempenham junto às crianças, sob seus cuidados diários. 
2. OBJETIVOS 


\subsection{OBJETIVO GERAL}

Este trabalho tem por objetivo geral analisar as relações existentes entre o desenvolvimento da linguagem oral de crianças de 4 anos e 1 mês a 5 anos e 4 meses de idade assistidas por auxiliares de desenvolvimento infantil e o tempo de acompanhamento, no contexto de uma creche.

\subsection{OBJETIVOS ESPECIFICOS}

Descrever a linguagem oral de crianças do maternal II, em diferentes tempos de acompanhamento, assistidas por auxiliares de desenvolvimento infantil previamente treinadas, no contexto de uma creche.

Verificar a associação entre os temas de linguagem, formação de conceitos, desenvolvimento fonêmico, produção de narrativas orais de crianças e o tempo de acompanhamento em períodos diversos, na creche em estudo. 


\section{A DESCRIÇÃO DA LINGUAGEM ORAL}




\subsection{DELINEAMENTO DA PESQUISA}

O presente trabalho refere-se a uma pesquisa experimental feita por meio de um estudo transversal e descritivo, no qual foi realizada a descrição do uso funcional da linguagem de crianças em diferentes períodos de acompanhamento em uma creche da cidade de São Paulo.

Com o intuito de oficializar e obtermos consentimento à realização da pesquisa cientifica neste contexto, inicialmente, contatamos a coordenadora das creches da Secretaria de Estado da Administração e Desenvolvimento Social e a diretora do CADI 34 (ANEXO 7).

\subsection{POPULAÇÃO}

Constituíram-se sujeitos da pesquisa, crianças do maternal II, matriculadas na creche CADI 34 Jd Elisa Maria.

Nosso critério para seleção dessas crianças foi pautado no tempo de acompanhamento realizado na creche por auxiliares de desenvolvimento infantil, isto é, crianças matriculadas no máximo há 6 meses e no mínimo há 4 anos, no número de crianças, no sexo e na ausência de problemas auditivos. 
As crianças matriculadas na creche há no minimo 6 meses nunca estiveram em instituição social infantil segundo informação referida pelos responsáveis e checadas no prontuário das mesmas.

A população em estudo compreendeu o total de 12 crianças, seis do sexo masculino e seis do sexo feminino.

Essas crianças provêm da comunidade vizinha à creche. São crianças, em sua maioria, oriundas de familias monoparentais, com precárias condiçōes sócio-econômicas, que residem em construçōes do tipo favela e outras na modalidade COHAB próximas à creche. Grande parte da área onde as crianças vivem é constituída por habitações construidas por meio de invasōes; a mesma residência, muitas vezes, é compartilhada por avós, tios, entre outras pessoas. A maioria das mães dessas crianças trabalha em serviços domésticos, como faxineiras ou diaristas; os pais, quando são declarados, quase na sua totalidade, sobrevivem realizando "bicos", ou seja, desenvolvem trabalhos temporários.

O consentimento da participação das crianças selecionadas foi manifestado por escrito por seus responsáveis, após as explicaçōes detalhadas da pesquisadora sobre os objetivos e estratégias para a descrição do uso funcional da linguagem (ANEXO 8). 


\subsection{INSTRUMENTO DE PESQUISA E COLETA DE DADOS}

A descrição do uso funcional da linguagem das crianças desta creche realizou-se por meio da utilização de um roteiro composto por três estratégias (ANEXO 9), as quais contemplaram a observação dos seguintes temas de linguagem: a formação de conceitos essenciais, o desenvolvimento fonêmico e a produção de narrativas orais.

Os materiais integrantes do instrumento utilizado para a descrição da linguagem oral das crianças estão apresentadas no ANEXO 10.

Os aspectos cognitivos não-lingüísticos constituem o sistema funcional da linguagem (CONDEMARÍN, CHADWICK, MILICIC, 1986). Utilizamos para a observação desses aspectos os critérios contidos nas Propostas Auxiliares do Exame de Linguagem elaborado por BRAZ, PELLICCIOTTI (1988).

Os aspectos cognitivos compreendem noção de esquema corporal, de espaço, de tamanho, de distância, de quantidade, de forma, de espessura, de altura, de comprimento, de igual-diferente, de seriação, de classificação, de seqüência lógico-temporal e nomeação e reconhecimento de cor. A formação desses conceitos foi observada por meio do manuseio de miniaturas, tais como representaçōes de utensilios de casa, animais, brinquedos, pessoas, figuras temáticas e figuras geométricas.

Utilizamos para a observação do desenvolvimento fonêmico os critérios elaborados por YAVAS, HERNANDORENA, LAMPRECHT (1992). A proposta apresenta cinco desenhos temáticos, a saber, veículos, sala, 
banheiro, cozinha e zoológico, capazes de eliciarem a amostra representativa da fala das crianças com a estimulação de 125 palavras. Estas palavras foram escolhidas por apresentarem uma representação equilibrada do sistema fonológico da língua portuguesa, apresentando os fonemas em diferentes contextos.

A habilidade da criança em realizar o ato motor de produção dos sons da fala e o sistema de regras lingüisticas que regem as combinações dos fonemas foram analisados no tema de linguagem desenvolvimento fonêmico (ISSLER, 1983; YAVAS, HERNANDORENA, LAMPRECHT, 1992).

$\mathrm{Na}$ observação das características de produção da fala foram notadas a identificação de hábitos orais, a mobilidade e funcionamento dos órgãos fonoarticulatórios e as habilidades perceptuais e motoras.

A elaboração das narrativas orais foi observada por meio da exposição das crianças a estímulos visuais em seqüência e figuras temáticas. Também foram registradas as narrativas decorrentes de manifestações espontâneas das crianças durante o periodo de realização das observações

Os contextos orais foram observados e descritos envolvendo os aspectos: estrutura da narrativa, elementos de coesão e coerência textual e propriedades semânticas, morfossintáticas e pragmáticas (GUEDES, 1984; BRAZ, PELLICCIOTTI, 1988; SIQUEIRA, 1991; YAVAS, HERNANDORENA, LAMPRECHT, 1992; AZCOAGA, 1992; PERRONI, 1992; GUEDES, 1997). 


\subsection{VARIÁVEIS DE ESTUDO}

As variáveis selecionadas e analisadas na descrição do uso funcional da linguagem das crianças foram assim definidas:

- No item Formação de Conceitos foram consideradas as seguintes variáveis:

$\diamond$ esquema corporal - quanto à ausência ou presença dessa noção;

$\diamond$ espaço - quanto à ausência ou presença dessa noção;

$\diamond$ tamanho - quanto à ausência ou presença dessa noção;

$\diamond$ distância - quanto à ausência ou presença dessa noção;

$\diamond$ quantidade - quanto à ausência ou presença dessa noção;

$\diamond$ forma - quanto à ausência ou presença dessa noção;

$\diamond$ espessura - quanto à ausência ou presença dessa noção;

$\diamond$ altura - quanto à ausência ou presença dessa noção;

$\diamond$ comprimento - quanto à ausência ou presença dessa noção;

$\diamond$ igual-diferente - quanto à ausência ou presença dessa noção;

$\diamond$ seqüência lógico-temporal - quanto à ausência ou presença dessa noção na ordenação de 3 e de 4 figuras.

$\diamond$ cor - quanto à ausência ou presença dessa noção; 
- No item Desenvolvimento Fonêmico foram considerados dois temas: a descrição fonêmica e as características de produção da fala. As variáveis envolvidas compreenderam:

$\diamond$ inventário fonológico - apresenta-se completo ou incompleto;

$\diamond$ inventário fonético - apresenta-se completo ou incompleto;

$\diamond$ sons consonantais - quanto à presença ou ausência de produção;

$\diamond$ sons vocálicos - quanto à presença ou ausência de produção;

$\diamond$ semi vogais - quanto à presença ou ausência de produção;

$\diamond$ arquifonemas - quanto à presença ou ausência de produção;

$\diamond$ grupos consonantais - quanto à presença ou ausência de produção;

$\diamond$ traços distintivos - quanto à presença ou ausência de produção;

$\diamond$ hábitos orais viciosos - quanto à ausência ou presença;

$\diamond$ tonicidade e mobilidade dos órgãos fonoarticulatórios em movimentos isolados - quanto à adequação ou inadequação dessas qualidades;

$\diamond$ posição dos órgãos fonoarticulatórios na articulação - quanto à adequação ou inadequação;

$\diamond$ habilidade perceptual na organização dos fonemas - quanto à adequação ou inadequação;

$\diamond$ habilidade motora em seqüência para a articulação dos fonemas quanto à presença ou ausência;

$\diamond$ fala espontânea - quanto à inteligibilidade ou ininteligibilidade. 
- No item Produção de Narrativas Orais as seguintes variáveis foram consideradas quanto à presença ou ausência de suas manifestações:

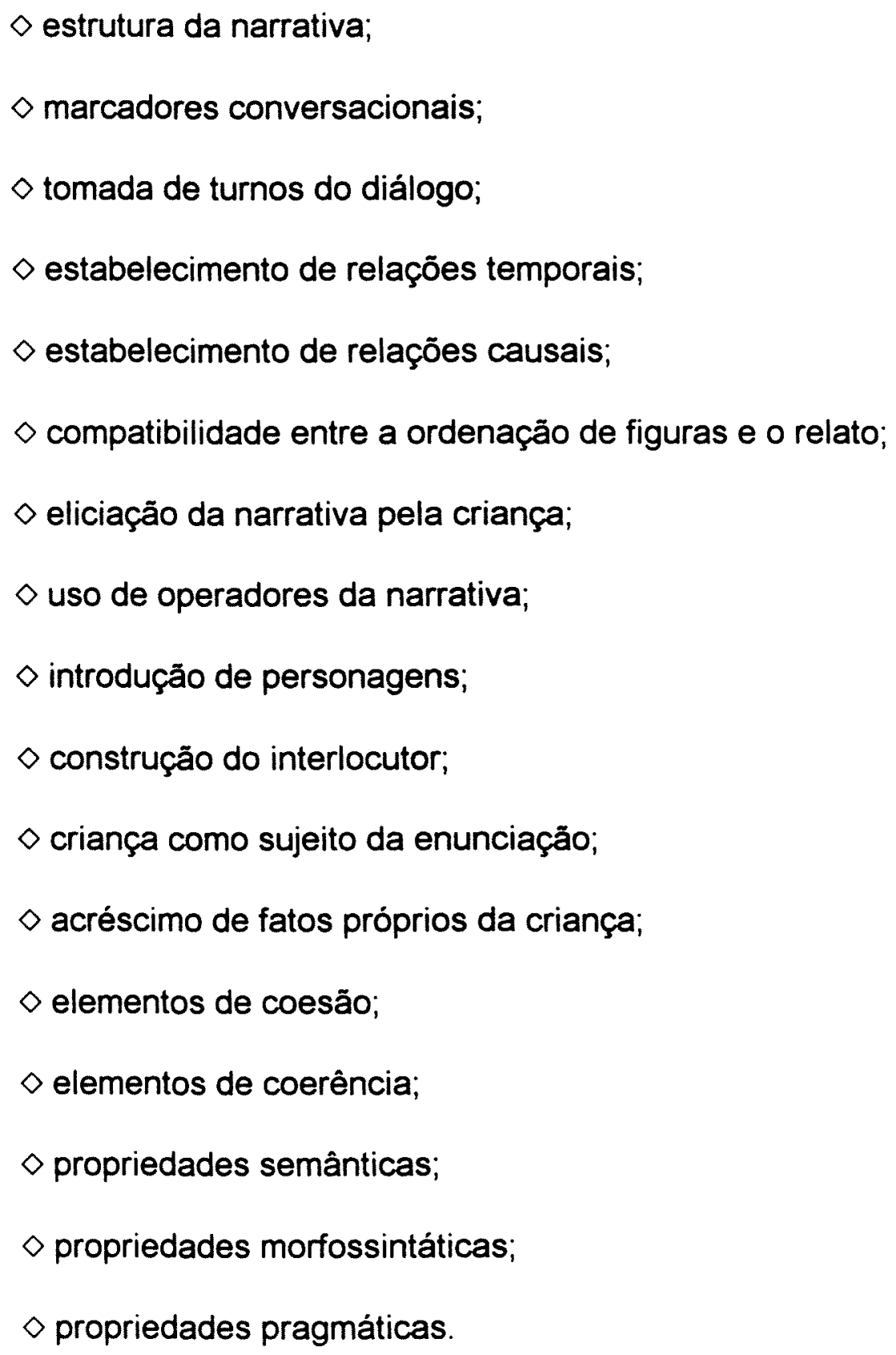




\subsection{DESEMPENHO DE CRIANÇAS QUANTO À DESCRIÇÃO DO}

\section{USO FUNCIONAL DA LINGUAGEM}

Elaboramos especificamente para este estudo um protocolo de registro dos resultados adquiridos (ANEXO 11) por meio do roteiro já apresentado em 3.3 .

Este protocolo compõe-se de três partes. Para cada parte atribuímos pontos diferenciados, de acordo com a sua importância na participação do emprego da linguagem no cotidiano.

À produção de narrativas orais atribuímos a maior pontuação por representar, por excelência, as condiçōes de expressão da linguagem oral da criança.

* Parte I - Formação de Conceitos - (pontos específicos = 24)

Compreendeu 12 temas. Cada um dos temas teve valor 2 , apresentando aspectos variados a serem verificados. O número desses aspectos, em cada tema, variou de 2 a 22, dependendo do tema. Em cada tema o valor 2 foi dividido proporcionalmente entre os aspectos observados. O total de pontos de cada tema, portanto, correspondeu à soma dos pontos obtidos segundo a presença do conceito proposto.

Os critérios utilizados para a pontuação dada ao desempenho em cada tema foi zero; menor ou igual a 1,00 e maior do que 1,00.

A partir daí as consideraçōes foram feitas da seguinte forma: 
* inadequado: quando não havia pontuação, ou seja, zero;

* insuficiente: quando havia alguma pontuação mas com valor inferior ou igual a 1,00 ;

* adequado: quando a pontuação no tema era superior a 1,00.

* Parte II - Desenvolvimento Fonêmico - (pontos especificos = 30)

Compreendeu a investigação de dois temas, a descrição fonêmica e caracteristicas de produção da fala. A cada um dos dois temas, atribuiu-se o valor 15. Em cada tema o valor foi dividido proporcionalmente entre os aspectos observados, ou seja, a descrição fonêmica apresentou oito aspectos e características de produção da fala seis aspectos. O total de pontos de cada tema, portanto, correspondeu à soma dos pontos obtidos.

Neste caso, o critério utilizado para a pontuação dada ao desempenho em cada tema foi zero; menor ou igual a 7,50 e maior do que 7,50 .

As considerações realizadas neste caso compreenderam:

* inadequado: quando não havia pontuação, ou seja, zero;

* insuficiente: quando havia alguma pontuação mas com valor inferior ou igual a 7,50 ;

* adequado: quando a pontuação no tema era superior a 7,50. 
* Parte III - Produção de Narrativas Orais - (pontos especificos = 46)

Compreendeu a descrição da narrativa dos sujeitos. Este tema apresentou 17 aspectos, os quais foram submetidos à observação da pesquisadora. Foi atribuído a esse tema o valor 46 , o qual foi dividido proporcionalmente entre os aspectos observados. $O$ total de pontos desse tema, portanto, correspondeu à soma dos pontos obtidos.

O critério utilizado para a pontuação do desempenho nesse tema foi zero; menor ou igual a 23,00 e maior a 23,00 .

As considerações realizadas neste caso foram:

* inadequada: quando não havia pontuação, ou seja zero;

* insuficiente: quando havia alguma pontuação mas com valor inferior ou igual a 23,00 ;

* adequada: quando a pontuação no tema era superior a 23,00 .

O desempenho geral (pontuação geral) manifestado pelas crianças foi determinado pela somatória das pontuações específicas em cada parte do instrumento de descrição do uso funcional da linguagem. O total geral foi de 100 pontos.

$$
\begin{aligned}
& \Sigma^{12}+\Sigma^{2}+\Sigma^{1}=100 \\
& i=2 \quad i=15 \quad i=46
\end{aligned}
$$

Sendo que $\mathrm{i}$ = pontuação específica do tema $\mathrm{i}$. 


\subsection{ANÁLISE DOS DADOS}

\subsubsection{Metodologia Estatistica Aplicada}

\subsubsection{Caracterização geral}

As comparações entre as porcentagens médias de percepção nos temas de linguagem entre grupos de crianças com ingresso recente na creche (igual ou menor há 6 meses) e crianças com 4 anos de acompanhamento são obtidas pelo teste de comparações múltiplas de Gabriel (MILLER 1981 apud SAS 1986).

Utilizamos a análise de conglomerados, pelo método de Ward (apud EVERITT, 1981), sobre a variável porcentagem média de percepção por tema e grupo ${ }^{1}$, com o objetivo de mostrar a presença de grupos empíricos e distintos de percentagens de percepção, como mais um recurso de análise de dados, que pudesse sugerir a diferenciação entre o tempo de acompanhamento e o desenvolvimento da linguagem das crianças na creche.

I Um de crianças com ingresso reconte na creche (igual ou menor a 6 meses) e outro de crianças com 4 anos ou mais de acompanhamento 
3.6.1.2. Estudo da associação entre os temas de linguagem de crianças com ingresso recente na creche (igual ou menor há 6 meses) e de crianças com 4 anos ou mais de acompanhamento

\subsection{Análise de Correspondências Múltiplas}

Para a apreciação qualitativa dos dados obtidos nos resultados utilizamos a Análise de Correspondências Múltiplas, ACM (ESCOFIER, PAGÉ, 1988) neste trabalho, com a finalidade de descrever a linguagem de crianças com ingresso recente na creche (igual ou menor há 6 meses) e crianças com 4 anos de acompanhamento na creche sob os seguintes temas: formação de conceitos (cor, forma, esquema corporal, posição no espaço, tamanho, distância, quantidade, espessura, altura, comprimento, igual-diferente e seqüência lógico temporal,), desenvolvimento fonémico (descrição fonêmica e característica da fala) e produção oral (narrativas orais).

A seguir, na Tabela 1 descrevem-se essas variáveis transformadas em modalidades, segundo os requisitos da análise da ACM, com suas freqüências relativas. A variável altura não foi considerada na análise porque o desempenho das crianças mostrou-se adequado em $100 \%$.

A ACM consiste em obter-se uma tipologia de crianças por tempo de acompanhamento na creche e uma tipologia dos temas e associá-las, finalizando em um estudo de semelhanças. 
O desempenho de duas crianças é considerado semelhante se os mesmos aspectos cognitivos presentes (ou ausentes) encontram-se no conjunto dos temas. No gráfico, simetricamente, dois temas estão presentes de forma associada no conjunto de crianças, se estão ausentes ou presentes ao mesmo tempo, como pode ser observado no capitulo dos resultados.

Mostrando quais são os fatores presentes ou ausentes comuns, entre as crianças de creche com mais tempo ou menos tempo de acompanhamento. Esta semelhança é medida pela distância do $\chi^{2}$, quiquadrado, chamada de Inércia Total.

A Inércia Total é projetada no Espaço Euclidiano, onde cada dimensão é conhecida como eixo principal. A cada eixo principal se associa uma inércia que corresponde à uma porcentagem de explicação da Inércia Total ou inércia parcial. Para auxiliar a seleção do número de eixos principais, acrescenta-se o cálculo das primeiras diferenças, $(s=2, \ldots, \mathrm{J})$, entre as suas inércias associadas aos eixos principais ou fatores principais. Selecionam-se os s-1 primeiros eixos principais, quando a s-ésima primeira diferença é maior que a (s-1)-ésima (HARMANN, 1976). 
Tabela 1. Descrição das Variáveis Transformadas em Modalidades Descritoras dos Temas de Linguagem formação de conceitos (cor, forma, esquema corporal, posição no espaço, tamanho, distância, quantidade, espessura, comprimento, igual-diferente e seqüência lógico temporal), desenvolvimento fonêmico (descrição fonêmica e características da fala) e produção de narrativas orais e, dos grupos de crianças com ingresso recente na creche (igual ou menor há 6 meses) e crianças com 4 anos de acompanhamento, CADI 34, São Paulo, 1999.

\begin{tabular}{|c|c|c|c|c|c|c|c|c|c|c|c|c|c|}
\hline \multicolumn{3}{|l|}{ Descriça } & \multicolumn{11}{|c|}{ Crianças } \\
\hline Variáveis & Modalidades & Códigos & CRT & $\mathrm{DL}$ & GS & LOB & TS & WS & CMG & JMP & KA & NO & RJSJ TAM \\
\hline \multicolumn{14}{|c|}{ Grupos com acompanhamento } \\
\hline \multicolumn{2}{|c|}{$\begin{array}{l}\text { menor ou igual a } 6 \text { meses } \\
\text { maior ou igual a } 4 \text { anos }\end{array}$} & GRUPO & 0,00 & 0,00 & 0,00 & 0,00 & 0,00 & 0,00 & 1,00 & 1,00 & 1,00 & 1,00 & $1,00 \quad 1,00$ \\
\hline \multicolumn{14}{|c|}{ desempenho(1) } \\
\hline \multicolumn{14}{|c|}{ Formação de conceitos } \\
\hline \multirow[t]{2}{*}{ Cor } & adequado & COR & 0,00 & 0,22 & 0.44 & 0,11 & 0.33 & 0,88 & 0,33 & 1,00 & 0,77 & 1,00 & $0,770,88$ \\
\hline & insul & CORO & 1,00 & 0,78 & 0,56 & 0,89 & 0,67 & 0,12 & 0,67 & 0,00 & 0,23 & 0,00 & $0,23 \quad 0,12$ \\
\hline \multirow[t]{2}{*}{ Forma } & adequ & FOR & 0,00 & 0,25 & 1,00 & 0,00 & 0,50 & 0,75 & 0,75 & 0,75 & 0,75 & 0,75 & $0,50 \quad 0,75$ \\
\hline & insuf & FOR0 & 1,00 & 0,75 & 0,00 & 1,00 & 0,50 & 0,25 & 0,25 & 0,25 & 0,25 & 0,25 & $0,50 \quad 0,25$ \\
\hline \multirow[t]{2}{*}{ Esquema } & adequado & $\mathrm{EC}$ & 0,68 & 0,72 & 0,81 & 0,72 & 0,81 & 0,81 & 0,90 & 0,86 & 0,86 & 0,86 & $0,90 \quad 0,86$ \\
\hline & insuficiente & EC0 & 0,33 & 0,28 & 0,19 & 0,28 & 0,19 & 0,19 & 0,10 & 0,15 & 0,15 & 0,15 & $0,10 \quad 0,15$ \\
\hline \multirow{4}{*}{$\begin{array}{l}\text { Posição no } \\
\text { espaço } \\
\text { Tamanho }\end{array}$} & adequado & PÉS & 0,75 & 0,60 & 0,30 & 0,30 & 0.60 & 0,90 & 0,90 & 0,90 & 0,60 & 1,00 & $0,90 \quad 1,00$ \\
\hline & insul & PESO & 0,25 & 0,40 & 0,70 & 0,70 & 0.40 & 0,10 & 0,10 & 0,10 & 0,40 & 0,00 & $0,10 \quad 0,00$ \\
\hline & adequado & TAM & 0,60 & 0,80 & 1,00 & 0,60 & 1,00 & 1,00 & 0,80 & 1,00 & 1,00 & 1,00 & $1,00 \quad 1,00$ \\
\hline & insuficiente & TAM0 & 0,40 & 0,20 & 0,00 & 0,40 & 0,00 & 0,00 & 0,20 & 0,00 & 0,00 & 0,00 & $0,00 \quad 0,00$ \\
\hline \multirow[t]{2}{*}{ Distância } & adequado & DIST & 0,00 & 0,00 & 1,00 & 0,00 & 1,00 & 1,00 & 1,00 & 1,00 & 1,00 & 1,00 & $0,00 \quad 1,00$ \\
\hline & insuficiente & DIST0 & 1,00 & 1,00 & 0,00 & 1,00 & 0,00 & 0,00 & 0.00 & 0,00 & 0,00 & 0,00 & $1,00 \quad 0,00$ \\
\hline \multirow[t]{2}{*}{ Quantidade } & adequado & QUAN & 0,00 & 0,50 & 0,00 & 0,00 & 1,00 & 1,00 & 1,00 & 1,00 & 1,00 & 1,00 & $1,00 \quad 1,00$ \\
\hline & insuficiente & QUAN & 1,00 & 0,50 & 1,00 & 1,00 & 0,00 & 0,00 & 0,00 & 0,00 & 0,00 & 0,00 & $0,00 \quad 0,00$ \\
\hline \multirow[t]{2}{*}{ Espessura } & adequado & ESP & 0,00 & 1,00 & 1,00 & 0,00 & 1.00 & 1.00 & 1.00 & 1,00 & 1,00 & 1,00 & 1.00 \\
\hline & iente & ESPO & 1,00 & 0,00 & 0,00 & 1,00 & 0,00 & 0,00 & 0,00 & 0,00 & 0,00 & 0,00 & $0,00 \quad 0,00$ \\
\hline \multirow[t]{2}{*}{ Comprimento } & adequado & COMP & 0.00 & 1,00 & 1,00 & 0.00 & 0.00 & 1,00 & 1,00 & 0,00 & 1,00 & 1,00 & $0,00 \quad 1,00$ \\
\hline & insuficiente & COMPO & 1,00 & 0.00 & 0,00 & 1,00 & 1,00 & 0,00 & 0,00 & 1,00 & 0.00 & 0,00 & $1,00 \quad 0,00$ \\
\hline Igual- & adequado & ID & 0,50 & 0,00 & 1,00 & 0,50 & 0,00 & 1,00 & 1,00 & 0,50 & 1.00 & 1,00 & $0,50 \quad 1,00$ \\
\hline Diferente & insuficiente & ID0 & 0,50 & 1,00 & 0,00 & 0,50 & 1.00 & 0,00 & 0,00 & 0,50 & 0,00 & 0,00 & $0,50 \quad 0,00$ \\
\hline Seq. lógico- & adequado & SLT & 0,00 & 0,00 & 0,50 & 0,00 & 0,50 & 1,00 & 1,00 & 0,50 & 0,50 & 0,50 & $1,00 \quad 1,00$ \\
\hline temporal & insuficientc & SLT0 & 1,00 & 1,00 & 0,50 & 1.00 & 0,50 & 0,00 & 0,00 & 0,50 & 0,50 & 0,50 & $0,00 \quad 0,00$ \\
\hline \multicolumn{14}{|c|}{ Desenvolvimento fonêmico } \\
\hline Descrição & adequado & DF & 0,29 & 0.43 & 0,57 & 0,29 & 0,57 & 0,43 & 0,71 & 1,00 & 1,00 & 0,71 & $1,00 \quad 0,86$ \\
\hline fonêmica & insuficiente & DF0 & 0.71 & 0,57 & 0,43 & 0.71 & 0,43 & 0,57 & 0.29 & 0,00 & 0.00 & 0.29 & $0,00 \quad 0,14$ \\
\hline Características & adequado & $\mathrm{CF}$ & 0.14 & 0,57 & 0,57 & 0.57 & 0.57 & 0.43 & 0.71 & 1,00 & 1.00 & 0,86 & $1.00 \quad 1,00$ \\
\hline $\begin{array}{l}\text { da fala } \\
\text { Produção Oral }\end{array}$ & insuficientc & CFO & 0.86 & 0.43 & 0.43 & 0,43 & 0.43 & 0.57 & 0.29 & 0,00 & 0,00 & 0,14 & $0,00 \quad 0,00$ \\
\hline Narrativas & adequado & NO & 0.23 & 0.23 & 0,76 & 0.41 & 0.94 & 0.47 & 0.94 & 0.76 & 1.00 & 0,94 & $0.88 \quad 0.70$ \\
\hline Orais & insuficientc & NO) & 0.77 & 0.77 & 0.24 & 0.59 & 0.06 & 0.53 & 0.06 & 0.24 & 0.00 & 0.06 & $0.12 \quad 0.30$ \\
\hline
\end{tabular}

(1)adequado $=$ proporção de pontos no tema: insuficiente $=$ proporção de pontos restantes para atingir a pontuação máxima no tema

Fonte: Dados da Pesquisa 


\subsubsection{Interpretação dos eixos principais}

O estudo de semelhanças entre modalidades baseia-se na interpretação dos eixos principais, quando são considerados os valores das inércias parciais de suas coordenadas sobre as Modalidades, que melhor explicam a \% de inércia dentro de cada eixo principal e as contribuições relativas das modalidades dentro de cada eixo (que são correlações entre as modalidades e os eixos principais). Assim, as Modalidades que explicam a maior \% de inércia dentro do eixo e têm maior contribuição relativa entre os eixos são as que melhor o definem, estabelecendo subconjuntos de Modalidades associadas (os eixos principais), que representarão as semelhanças ou diferenças entre os grupos de crianças de creche com mais tempo e menos tempo de acompanhamento, segundo os temas de linguagem descritos.

As matrizes de dados geradas foram processadas utilizando-se 0 Sistema de Análises Estatísticas, SAS, 1986(versão 6.02).

\subsection{QUESTÕES ÉTICAS}

De acordo com a Resolução no 196 de 10/10/1996 do Conselho Nacional de Saúde sobre as pesquisas científicas desenvolvidas em seres humanos, esse trabalho adotou procedimentos que garantiram a não 
discriminação dos sujeitos envolvidos na pesquisa assim como o consentimento livre e esclarecido dos seus responsáveis (ANEXO 8).

A privacidade, a confidencialidade de dados e 0 anonimato dos sujeitos participantes foram garantidos e os valores sócio-culturais foram respeitados.

Os resultados da pesquisa serão publicados, sejam favoráveis ou não. A liberdade de retirar o consentimento a qualquer momento e deixar de participar do estudo também foi garantida.

Quaisquer dúvidas sobre os procedimentos, riscos e beneficios relacionados à pesquisa foram esclarecidos e houve o compromisso de proporcionar informação atualizada obtida durante o estudo, ainda que pudesse afetar a vontade dos responsáveis pelos sujeitos em continuar participando. 
4. RESULTADOS 


\subsection{CARACTERIZAÇÃO GERAL}

O uso funcional da linguagem foi observado em 12 crianças pertencentes à turma do maternal II, seis crianças do sexo masculino e seis do sexo feminino, com idade variável entre 4 anos e 1 mês a 5 anos e 4 meses.

Estabelecemos dois grupos de crianças, um grupo constituido por seis crianças com ingresso recente na creche (igual ou menor há 6 meses) e outro grupo constituido por seis crianças com 4 anos ou mais de acompanhamento na creche.

Os grupos estão demonstrados na Tabela 2. 
Tabela 2. Distribuição das crianças segundo 0 tempo de acompanhamento na creche, o sexo e a idade, CADI 34, São Paulo, 1999.

\begin{tabular}{cccc}
\hline GRUPO & CRIANÇAS & SEXO & IDADE \\
\hline \multirow{3}{*}{6 MESES } & WS & masc. & 5 a e $3 \mathrm{~m}$ \\
& CRT & masc. & 4 a e $4 \mathrm{~m}$ \\
& LOBG & masc. & 4 a e $1 \mathrm{~m}$ \\
& TSA & fem. & 5 a e $1 \mathrm{~m}$ \\
& DLG & fem. & 4 a e $6 \mathrm{~m}$ \\
& GS & fem. & 4 a e $4 \mathrm{~m}$ \\
\hline \multirow{3}{*}{4 ANOS } & JMP & masc. & 5 a e $4 \mathrm{~m}$ \\
& KA & masc. & 4 a e $4 \mathrm{~m}$ \\
& RJSJ & masc. & 4 a e $2 \mathrm{~m}$ \\
& CMG & fem. & 5 a e $3 \mathrm{~m}$ \\
& NO & fem. & 4 a e $7 \mathrm{~m}$ \\
& TAML & fem. & 4 a e $5 \mathrm{~m}$ \\
\hline
\end{tabular}

Fonte: Dados da Pesquisa.

As crianças, sujeitos da pesquisa, assim como as demais crianças da creche, foram submetidas à observação da orelha externa por meio da otoscopia e à Triagem Audiométrica e Imitanciométrica com o objetivo de se identificarem as condições de audição e de orelha média. Os achados das crianças participantes da pesquisa constam no ANEXO 12.

A seguir apresentamos os resultados específicos, segundo os temas de linguagem, formação de conceitos, desenvolvimento fonêmico e produção de narrativas orais. 
O desempenho, em porcentagem, de cada criança dentro de seu grupo está demonstrado por meio de gráficos em barras horizontais.

Inicialmente, apresentamos os resultados dos grupos $6 \mathrm{~m}$ e $4 \mathrm{a}$ quanto à formação de conceitos (Figura 1 e Figura 2), o desenvolvimento fonêmico (Figura 3 e Figura 4) e a produção de narrativas orais (Figura 5 e Figura 6). Na Figura 7 e na Figura 8 demonstramos o desempenho geral em porcentagem de cada criança nos grupos em questão segundo o Desenvolvimento da Linguagem.

Finalizando a descrição do uso funcional da linguagem na Figura 9 expomos a comparação das médias das porcentagens de percepção dos temas de linguagem entre os dois grupos estudados.

No ANEXO 13, apresentamos o desempenho de todas as crianças submetidas à descrição da linguagem e a pontuação específica de cada variável em cada grupo de crianças.

4.1.1. Desempenho específico de crianças dos grupos $6 \mathrm{~m}$ e $4 a$ segundo o tema de linguagem Formação de Conceitos

Observamos na Figura 1 que três (50\%) crianças do grupo de 6 meses ou menos de acompanhamento na creche manifestaram um 
desempenho acima de $60 \%$ no tema de linguagem formação de conceitos, WS, GS e TS (respectivamente $94,50 \%, 75,41 \%$ e $64,75 \%$ ). A criança DLG obteve um desempenho mediano compreendendo $50,75 \%$. As crianças que complementam esse grupo (33\%) expressaram um desempenho insuficiente para este tema, são elas, CRT (29,37\%) e LOBG $(26,91 \%)$.

Figura 1. Desempenho específico segundo o tema de linguagem Formação de Conceitos de crianças com 6 meses ou menos de acompanhamento na creche, CADI 34, São Paulo, 1999.

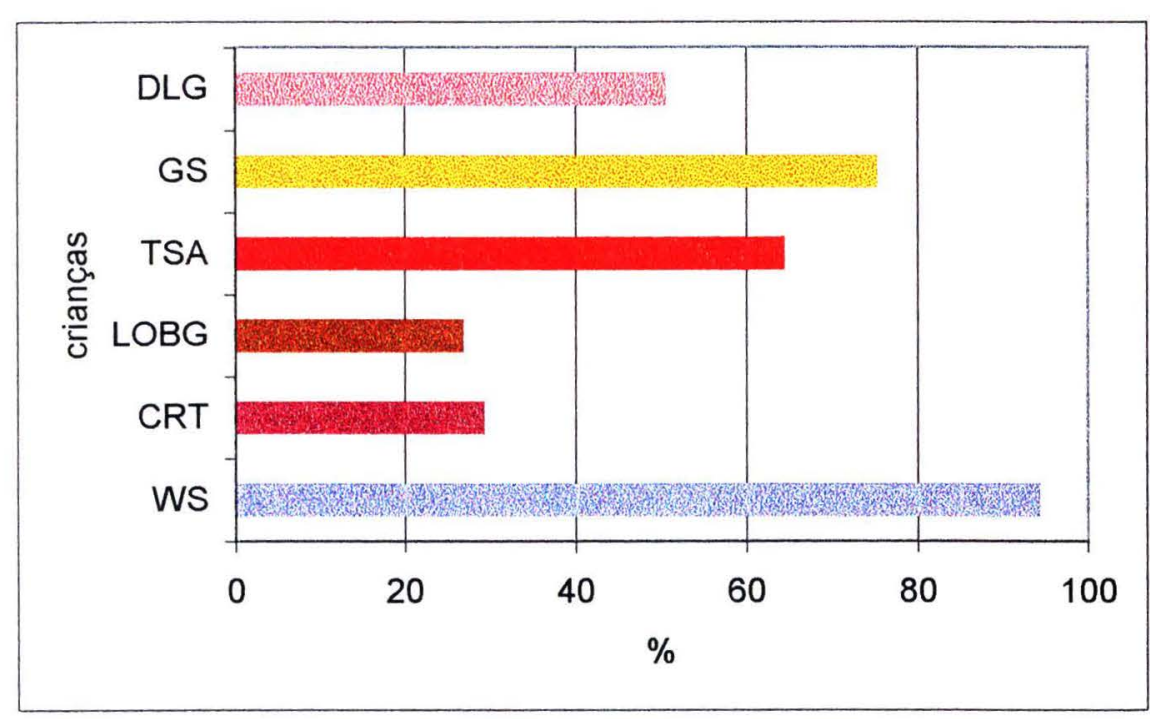

O desempenho do grupo de crianças de 4 anos ou mais de acompanhamento na creche segundo o tema de linguagem formação de conceitos está evidenciado na Figura 2 na qual observamos que todas as crianças obtiveram um desempenho acima de $70 \%$. A criança com maior 
desempenho foi TAML $(95,70 \%)$, seguida das demais, NO (92,54\%), CMG (89\%), KA (87,29\%), JMP $(79,20 \%)$ e RSJS $(71,41 \%)$.

Figura 2. Desempenho específico segundo o tema de linguagem Formação de Conceitos de crianças com 4 anos ou mais de acompanhamento na creche, CADI 34, São Paulo, 1999.

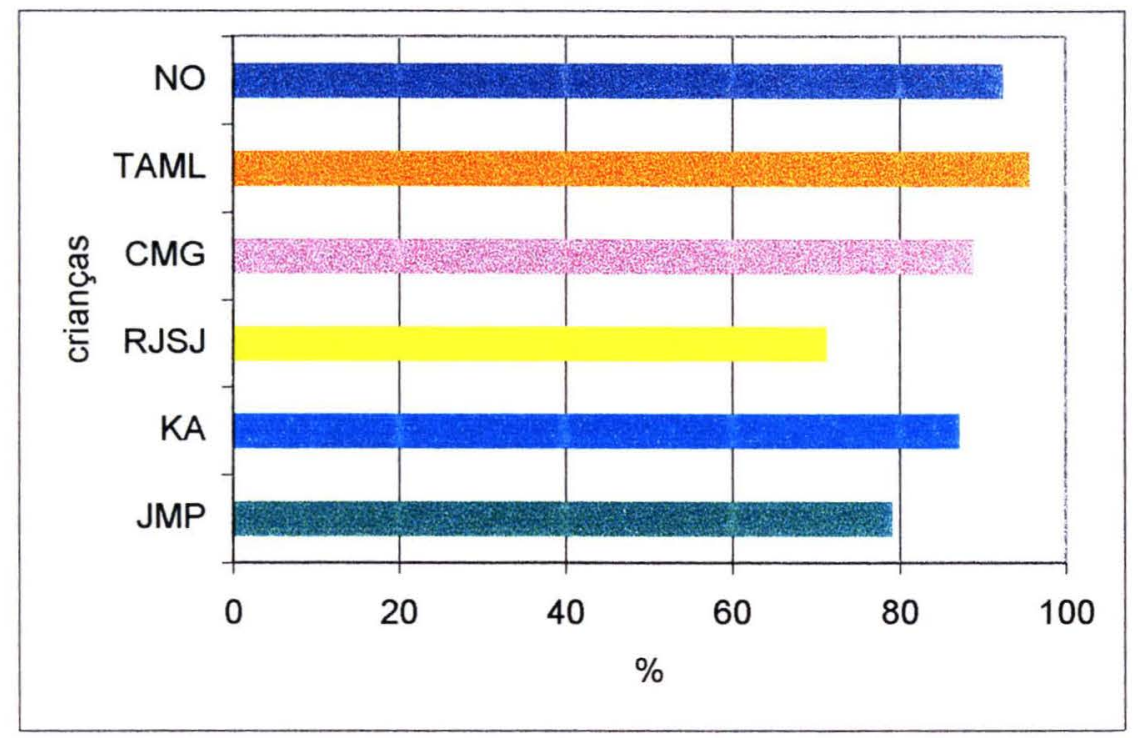

Com referência ao tema de linguagem formação de conceitos, os dados apresentados sugerem uma maior diversidade no desempenho das crianças do grupo de 6 meses ou menos de acompanhamento na creche (Figura 1) diferente da manifestação das crianças do grupo de 4 anos ou mais de acompanhamento na creche (Figura 2), as quais expressam desempenhos semelhantes neste item. 


\subsubsection{Desempenho específico de crianças dos grupos $6 \mathrm{~m}$ e $4 \mathrm{a}$ segundo o tema de linguagem Desenvolvimento Fonêmico}

Os dados apresentados na Figura 3 e na Figura 4 evidenciam, respectivamente, o desempenho das crianças dos grupos de 6 meses ou menos de acompanhamento na creche e de 4 anos ou mais de acompanhamento na creche segundo o tema de linguagem desenvolvimento fonêmico.

Notamos que todas as crianças do grupo $6 \mathrm{~m}$ revelaram um desempenho abaixo de $60 \%$ neste tema de linguagem como podemos observar na Figura 3. Os resultados expressos informam que GS e TSA obtiveram desempenhos iguais de 57,06\%; DLG, 49,93\%; LOBG e WS também obtiveram desempenhos iguais de $42,80 \%$ e CRT apresentou $21,40 \%$

No que diz respeito às crianças do grupo 4 a (Figura 4) três delas (50\%) evidenciaram um ótimo desempenho (100\%) na descrição deste item (RJSJ, KA e JMP), obtendo também um ótimo desempenho a criança TAML com $92,80 \%$. Ao passo que NO e CMG expressaram seus desempenhos em $78,46 \%$ e $71,33 \%$ respectivamente.

Quando consideramos os dois grupos, verificamos que os dados apresentados na Figura 3 e na Figura 4 sugerem diferentes desempenhos.

As crianças com 4 anos ou mais de acompanhamento na creche manifestam um desempenho adequado, já aquelas com 6 meses ou menos 
de acompanhamento na creche revelam um desempenho insuficiente nesse tema de linguagem.

Figura 3. Desempenho específico de crianças com 6 meses ou menos de acompanhamento na creche segundo o tema de linguagem Desenvolvimento Fonêmico, CADI 34, São Paulo, 1999.

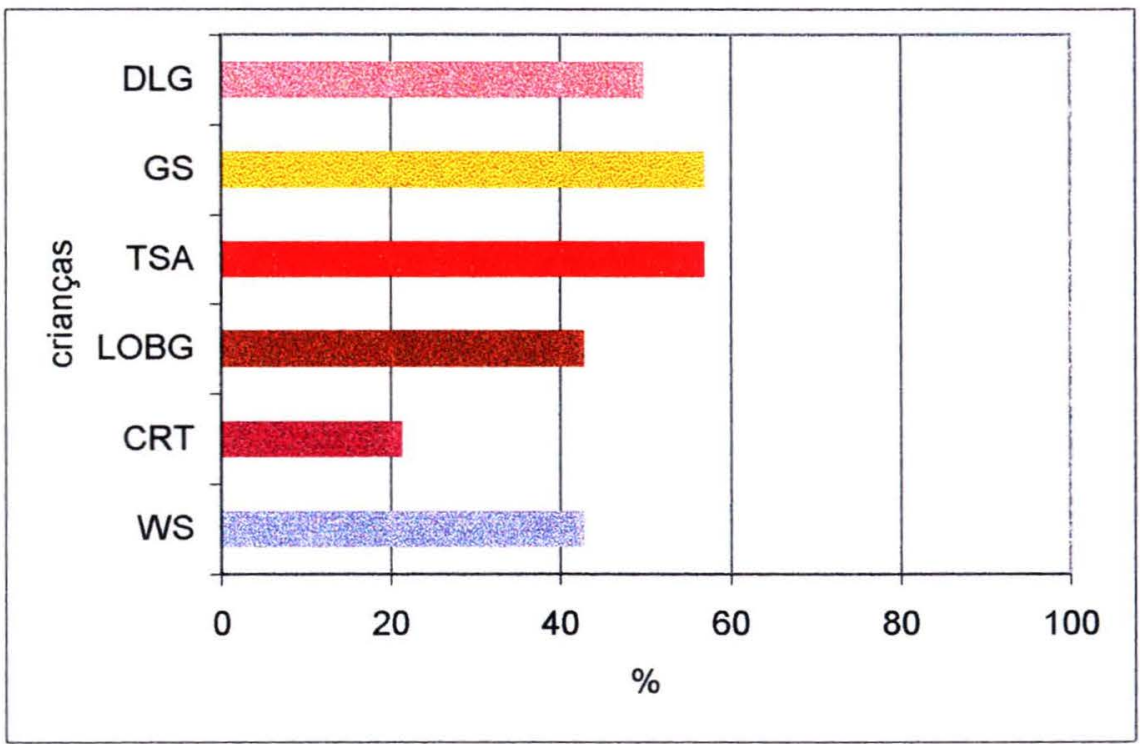


Figura 4. Desempenho especifico de crianças com 4 anos ou mais de acompanhamento na creche segundo o tema de linguagem Desenvolvimento Fonêmico, CADI 34, São Paulo, 1999.

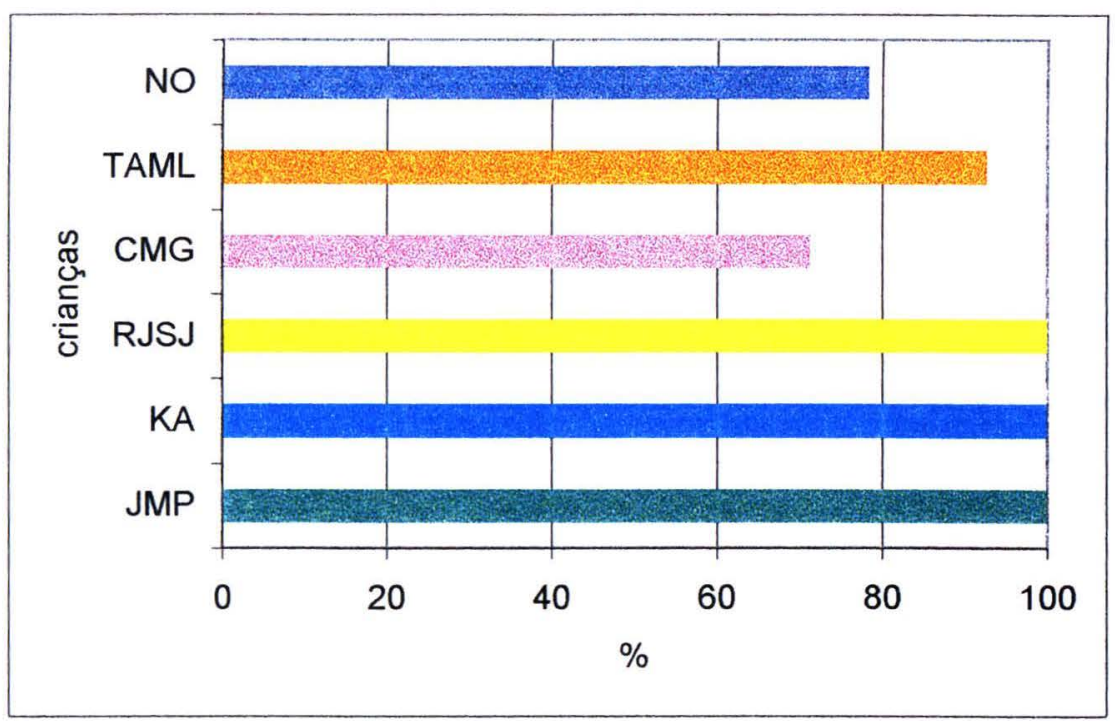

4.1.3. Desempenho específico de crianças dos grupos $6 \mathrm{~m}$ e $4 a$ segundo o tema de linguagem Produção de Narrativas Orais

Na Figura 5 observamos o desempenho das crianças do grupo $6 \mathrm{~m}$ segundo o tema de linguagem produção oral.

Expressa-se evidente o desempenho adequado para este tema de linguagem de duas crianças (33\%) nesse grupo, TSA $(93,91 \%)$ e GS (76,30\%), distanciando-se das outras crianças, que, no entanto, revelam um desempenho insuficiente, a saber, WS (46,95\%), LOBG $(41,08 \%)$, DLG $(23,47 \%)$ e CRT $(23,47 \%)$. 
O desempenho do grupo de crianças de 4 anos ou mais de acompanhamento na creche em relação ao tema de linguagem produção oral está evidenciado na Figura 6.

Observamos que todas as crianças (100\%) deste grupo apresentam um desempenho adequado para este tema, acima de $70 \%$ : NO $(93,91 \%)$, CMG $\quad(93,91 \%), \quad$ RJSJ $\quad(88,04 \%), \quad J M P \quad(76,30 \%), \quad$ TAML $\quad(70,43 \%)$; salientando-se o desempenho máximo (100\%) para a descrição do item revelado por KA. 
Figura 5. Desempenho específico de crianças com 6 meses ou menos de acompanhamento na creche segundo o tema de linguagem Produção de Narrativas Orais, CADI 34, São Paulo, 1999.

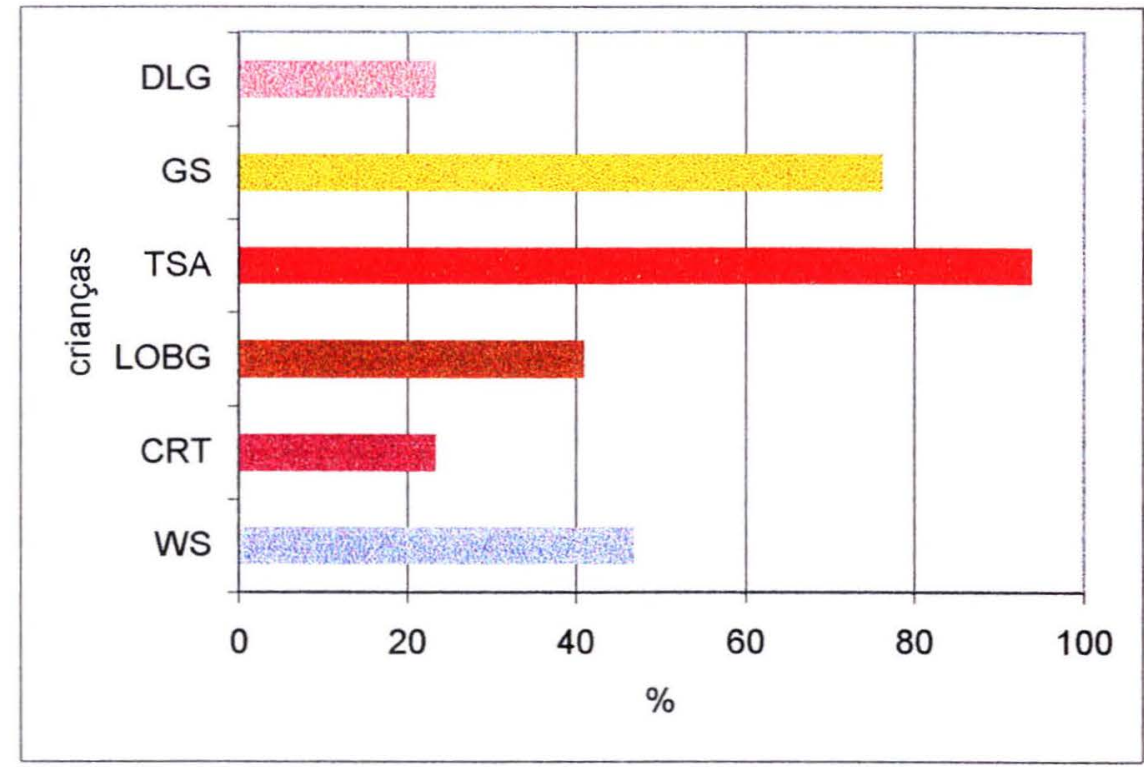

Figura 6. Desempenho especifico de crianças com 4 anos ou mais de acompanhamento na creche segundo o tema de linguagem Produção de Narrativas Orais, CADI 34, São Paulo, 1999.

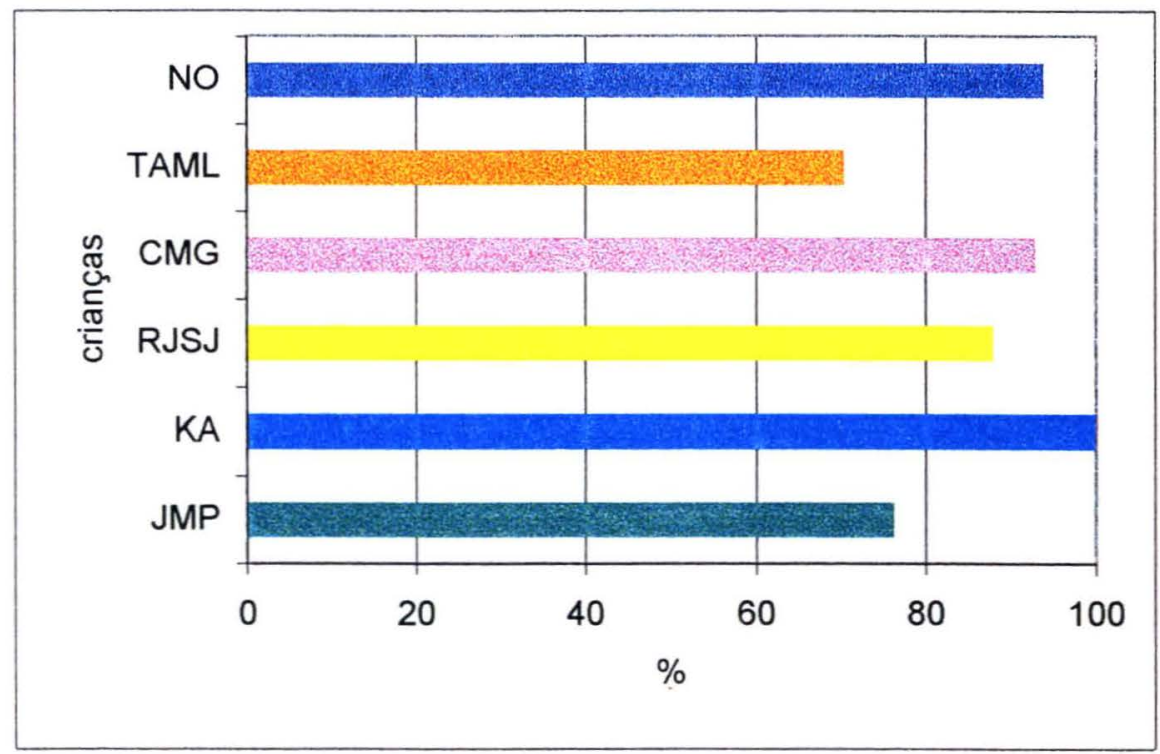


Com referência ao desempenho das crianças, de ambos os grupos, no tema de linguagem produção oral, verificamos que duas crianças do grupo $6 \mathrm{~m}$ (TSA e GS) se manifestam de maneira semelhante quanto ao desempenho adequado manifestado por todas as crianças do grupo $4 a$, como podemos identificar na Figura 5 e na Figura 6

\subsubsection{Desempenho geral de crianças dos grupos $6 \mathrm{~m}$ e $4 a$ segundo o Desenvolvimento da Linguagem}

Os dados apresentados na Figura 7 e na Figura 8 expressam, resumidamente, a média do desempenho geral das crianças dos grupos $6 \mathrm{~m}$ e 4a, respectivamente, segundo o desenvolvimento da linguagem. Essas figuras apresentam um consolidado geral do desempenho obtido pelas crianças nos temas de linguagem formação de conceitos, desenvolvimento fonêmico e produção de narrativas orais. 
Figura 7. Desempenho geral de crianças com 6 meses ou menos de acompanhamento na creche segundo o Desenvolvimento da Linguagem, CADI 34, São Paulo, 1999.

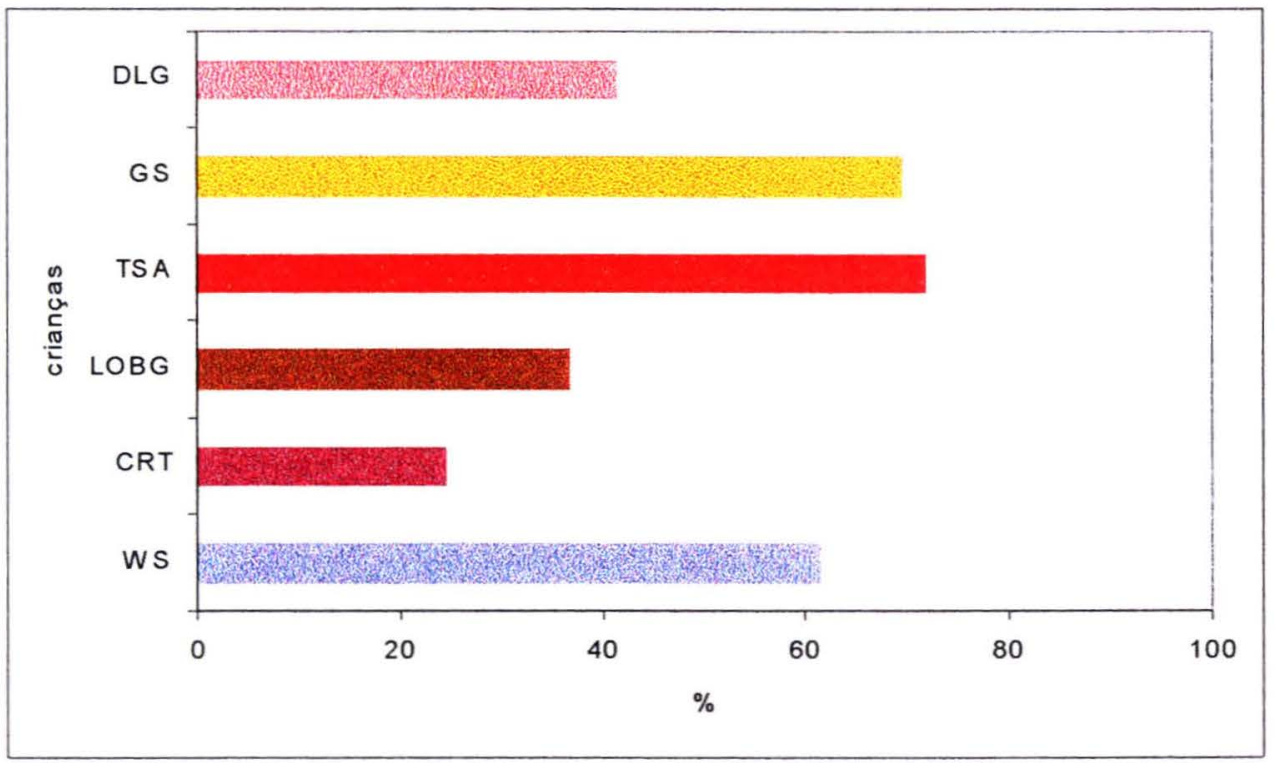

Figura 8. Desempenho de crianças com 4 anos ou mais de acompanhamento na creche segundo o Desenvolvimento da Linguagem, CADI 34, São Paulo, 1999.

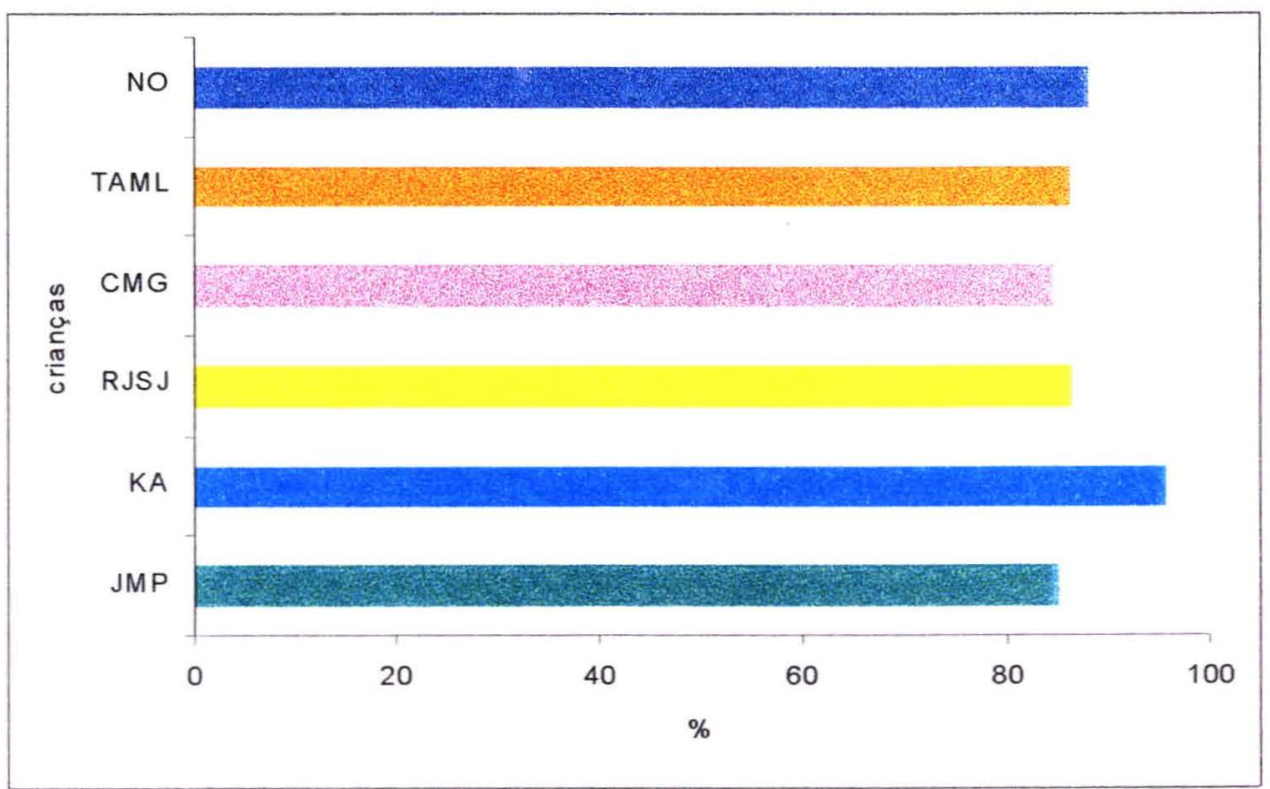


Como observamos na Figura 7 as crianças do grupo $6 \mathrm{~m}$ têm porcentagens de percepção bastante diferenciadas que variaram entre $24,75 \%$ e $71,82 \%$.

O grupo 4a apresentou, no entanto, valores bem próximos, acima de $80 \%$ (variando entre $84,74 \%$ e $96,76 \%$ ), como podemos observar na Figura 8

Esse resultado sugere uma possivel heterogeneidade no desenvolvimento da linguagem entre as crianças mais recentes em contraposiçāo a homogeneidade apresentada pelas crianças com 4 anos ou mais de acompanhamento

Um teste estatístico de comparação entre as médias das porcentagens de percepção dos dois grupos foi realizado e mostra a superioridade da média do segundo grupo (4a), ou seja, a porcentagem média de percepção do segundo grupo é maior do que a do primeiro grupo (6m), ao nivel de significância de 5\%, pelo teste de Gabriel (Figura 9) 
Figura 9. Média das porcentagens de percepção dos temas de linguagem dos grupos 6m e 4a, CADI 34, São Paulo, 1999 (1).

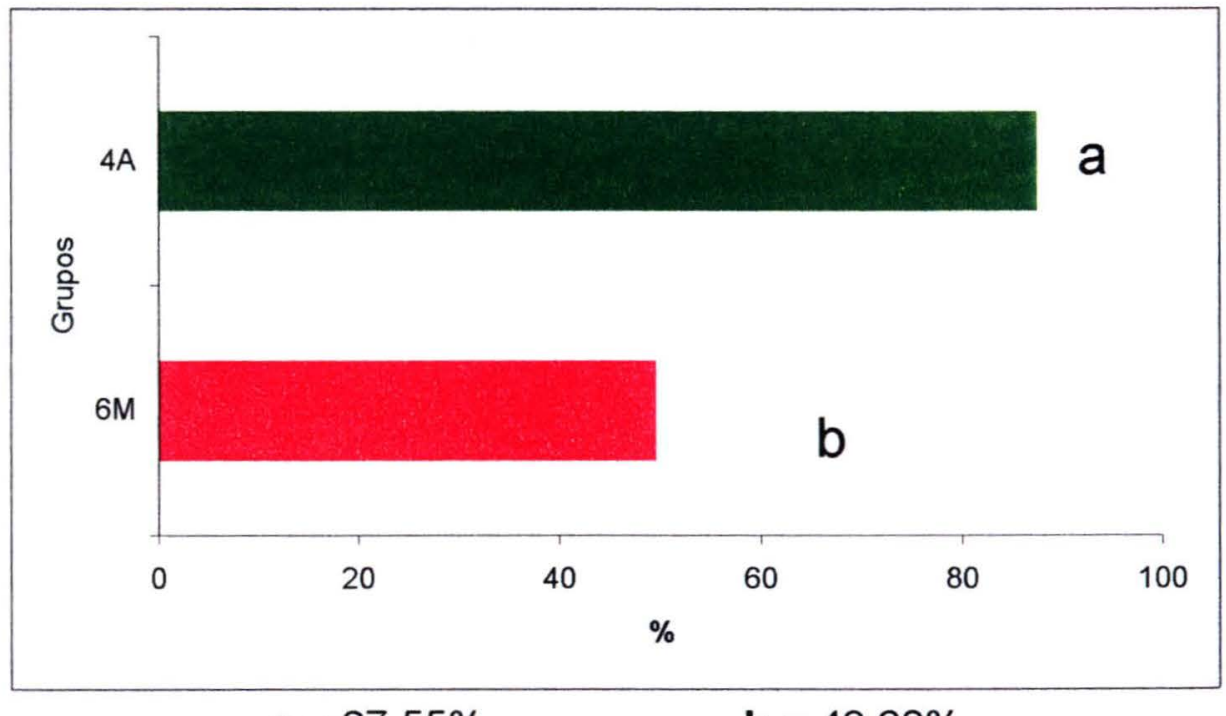

$\mathbf{a}=87,55 \% \quad \mathbf{b}=49,60 \%$

(1) proporções com as mesmas letras não são significantes $(\alpha=0,05)$ pelo teste de Gabriel.

A mesma comparação é realizada levando em consideração a variável porcentagem média de percepção por tema e grupo.

Inicialmente os valores dessa variável são classificados através de uma análise de conglomerados, com o objetivo de analisar a presenças de grupos empíricos e distintos de percentagens de percepção. Com 94\% de explicação da inércia total dos valores dessa variável, encontramos 4 grupos que descrevemos a seguir. 


\begin{tabular}{cc}
\hline $\begin{array}{c}\text { Percepção em temas de } \\
\text { linguagem }\end{array}$ & $\begin{array}{c}\text { Porcentagem média de } \\
\text { percepção por tema e grupo }\end{array}$ \\
\hline alta & $83,00 \%$ a $100,00 \%$ \\
média & $67,00 \%$ a $79,00 \%$ \\
baixa & $48,00 \%$ a $57,50 \%$ \\
muito baixa & $33,00 \%$ a $43,00 \%$ \\
\hline
\end{tabular}

Fonte: Dados da Pesquisa

A seguir, associamos os valores dessa variável porcentagem média de percepção por tema e grupo, como apresentamos no Quadro 1 aos temas e aos grupos a que pertenciam inicialmente.

Evidenciamos a intensidade da percepção por tema e grupo com 4 cores diferentes correspondentes aos 4 grupos observados. Com isto, mostramos também, que o grupo de crianças $6 \mathrm{~m}$ apresenta uma maior variabilidade entre as \% médias de percepção por tema do que as crianças 4a, enfatizando a possivel diferenciação entre o tempo de acompanhamento e o desenvolvimento da linguagem das crianças na creche 
Quadro 1. Representação da Escala de Percepção em Temas de Linguagem de crianças em diferentes tempos de acompanhamento na creche.

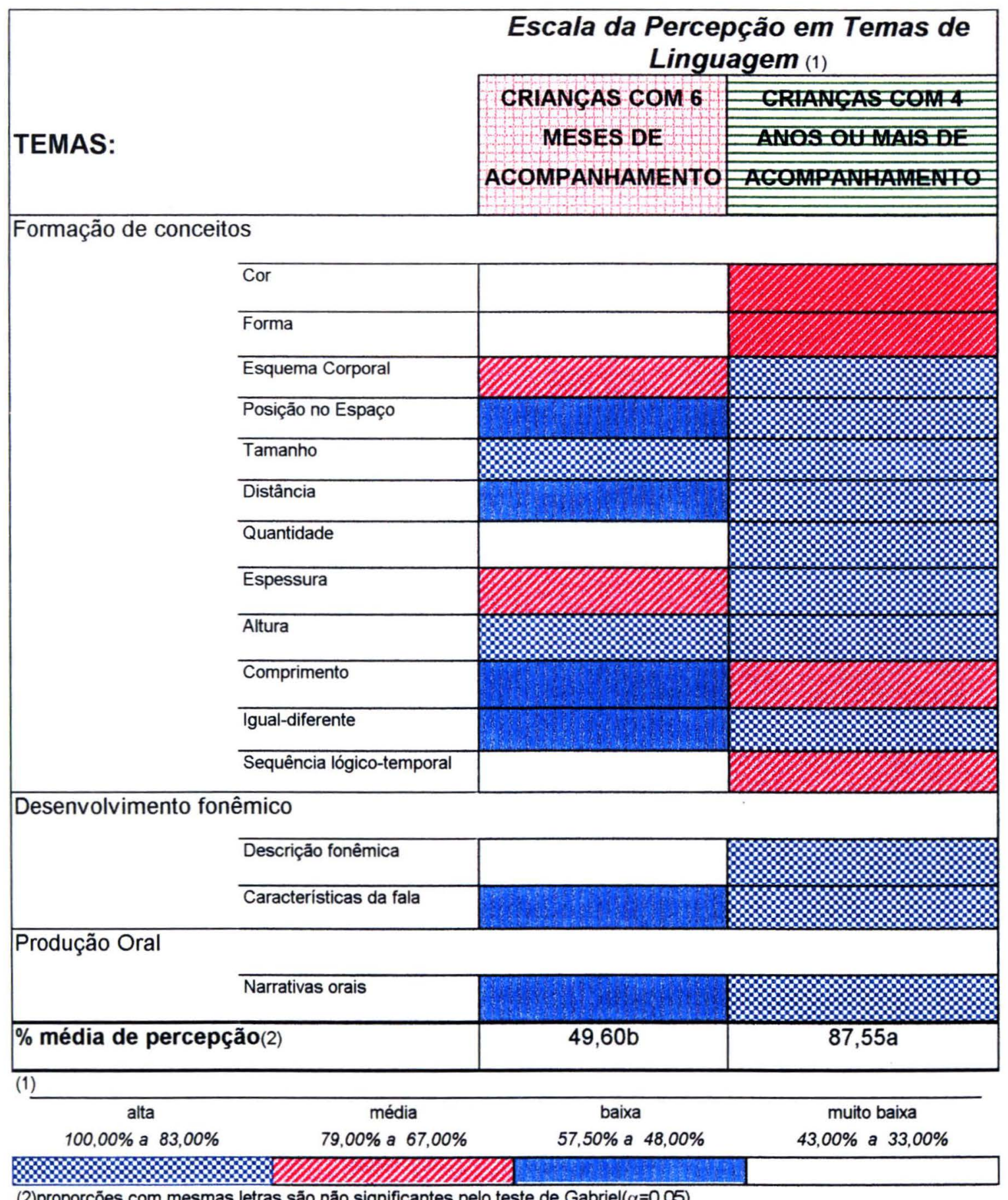

(2)proporções com mesmas letras são não significantes pelo teste de $\operatorname{Gabriel}(\alpha=0,05)$

Fonte: Dados da Pesquisa 


\begin{abstract}
4.2. ESTUDO DA ASSOCIAÇÃO DA LINGUAGEM DE CRIANÇAS COM INGRESSO RECENTE NA CRECHE (IGUAL OU MENOR HÁ 6 MESES) E AS CRIANÇAS COM 4 ANOS OU MAIS DE ACOMPANHAMENTO
\end{abstract}

4.2.1. Tipologia dos Temas de Linguagem

4.2.1.1. Descrição dos eixos principais

A aplicação da Análise de Correspondência Múltipla (ACM) resultou nas inércias associadas, \% inércia parcial, \% inércia acumulada e primeiras diferenças apresentadas na Tabela 3.

Tabela 3. Inércias associadas, $\%$ inércia parcial, $\%$ inércia acumulada e primeiras diferenças.

\begin{tabular}{ccccc}
\hline \multicolumn{5}{c}{ Decomposicåo da Inércia Total } \\
\hline Eixo principal & $\begin{array}{c}\text { Inércia } \\
\text { associada }\end{array}$ & $\begin{array}{c}\text { \% de } \\
\text { inércia } \\
\text { parcial }\end{array}$ & $\begin{array}{c}\text { Primeiras } \\
\text { diferenças }\end{array}$ & $\begin{array}{c}\text { \% de inércia } \\
\text { acumulada }\end{array}$ \\
\hline F1 & 0,32518 & $57,25 \%$ & $41,71 \%$ & $57,25 \%$ \\
F2 & 0,08828 & $15,54 \%$ & $6,60 \%$ & $72,79 \%$ \\
F3 & 0,05079 & $8,94 \%$ & $2,74 \%$ & $81,73 \%$ \\
F4 & 0,03519 & $6,20 \%$ & $1,47 \%$ & $87,93 \%$ \\
F5 & 0,02686 & $4,73 \%$ & $1,81 \%$ & $92,66 \%$ \\
F6 & 0,01659 & $2,92 \%$ & $0,43 \%$ & $95,58 \%$ \\
F7 & 0,01415 & $2,49 \%$ & $1,50 \%$ & $98,07 \%$ \\
F8 & 0,00563 & $0,99 \%$ & - & $99,06 \%$ \\
\hline
\end{tabular}

Fonte: Dados da Pesquisa. 
Dois subconjuntos das 30 modalidades totais contribuiram para definir a associação entre elas explicando $72,79 \%$ da inércia total. Na Tabela 4 encontramos as coordenadas das modalidades e as suas inércias parciais e relativas dentro de cada eixo principal. 
Tabela 4. Códigos, coordenadas, inércias parciais e relativas nos dois primeiros eixos principais, segundo os Temas de Linguagem: formação de conceitos (cor, forma, esquema corporal, posiçăo no espaço, tamanho, distância, quantidade, espessura, altura, comprimento, igual-diferente e seqüência lógico temporal), desenvolvimento fonêmico (descrição fonêmica e caracteristicas de produção da fala) e produçāo de narrativas orais.

\begin{tabular}{|c|c|c|c|c|c|c|c|c|}
\hline \multirow{2}{*}{$\begin{array}{r}\text { Descriçåo } \\
\text { Modalidades }\end{array}$} & & \multirow[b]{2}{*}{ Códigos } & \multicolumn{2}{|c|}{ Coordenadas } & \multicolumn{2}{|c|}{$\begin{array}{c}\text { Contribuiço } \\
\text { parcial }\end{array}$} & \multicolumn{2}{|c|}{$\begin{array}{l}\text { Contribuiçæo } \\
\text { relativa(\%) }\end{array}$} \\
\hline & & & F1 & F2 & F1 & F2 & Fl & F2 \\
\hline \multicolumn{3}{|c|}{ GRUPOI=acompanhamento menor ou igual a 6 meses } & 0,75 & $-0,45$ & 0,06 & 0,08 & $\mathbf{3 , 3 2}$ & 1,18 \\
\hline \multicolumn{3}{|c|}{$\begin{array}{c}\text { GRUPO2=acompanhamento maior ou igual a } 4 \text { anos } \\
\text { desempenho(1) }\end{array}$} & $-0,75$ & 0,45 & 0,06 & 0,08 & 3,32 & 1,18 \\
\hline \multicolumn{9}{|c|}{ Formação de conceitos } \\
\hline Cor & $\begin{array}{l}\text { adoquado } \\
\text { insuficiante }\end{array}$ & $\begin{array}{l}\text { COR } \\
\text { CORO }\end{array}$ & $\begin{array}{l}-0,52 \\
0,66\end{array}$ & $\begin{array}{l}0,09 \\
-0,12\end{array}$ & $\begin{array}{l}0.03 \\
0.04\end{array}$ & $\begin{array}{l}0,00 \\
0,00\end{array}$ & $\begin{array}{l}1,78 \\
2.27\end{array}$ & $\begin{array}{l}0,06 \\
0,07\end{array}$ \\
\hline \multirow[t]{2}{*}{ Forma } & adequado & FOR & $-0,48$ & $-0,18$ & 0,03 & 0,01 & 1,54 & 0,22 \\
\hline & insuficiente & FORO & 0,62 & 0,23 & 0,03 & 0,02 & 1,97 & 0,28 \\
\hline \multirow[t]{2}{*}{ Esquema Corporal } & adequado & EC & $-0,08$ & 0,02 & 0,00 & 0,00 & 0,06 & 0,00 \\
\hline & insuficiente & ECO & 0,34 & $-0,09$ & 0,00 & 0,00 & 0,26 & 0,02 \\
\hline \multirow[t]{2}{*}{ Posiçio no Espapo } & adequado & PÉS & $-0,19$ & 0,11 & 0,01 & 0,01 & 0,32 & 0,11 \\
\hline & insuficiente & PESO & 0,52 & $-0,30$ & 0,02 & 0,02 & 0,87 & 0,29 \\
\hline \multirow[t]{2}{*}{ Tammaho } & adequado & TAM & $-0,14$ & 0,00 & 0,00 & 0,00 & 0,22 & 0,00 \\
\hline & insuficiante & TAMO & 1,29 & 0,02 & 0,03 & $0, \infty$ & 1,96 & 0,00 \\
\hline \multirow[t]{2}{*}{ Dissincin } & adequado & DIST & $-0,55$ & $-0,25$ & 0,04 & 0,03 & 2,36 & 0,49 \\
\hline & insuficionte & DISTO & 1,10 & 0,50 & 0,08 & 0,06 & 4,72 & 0,98 \\
\hline \multirow[t]{2}{*}{ Quantidade } & adequedo & QUANT & $-0,51$ & 0,20 & 0,04 & 0,02 & 2,15 & 0,35 \\
\hline & insuficiente & QUANTO & 1,24 & $-0,50$ & 0,09 & 0,05 & 5,23 & 0,85 \\
\hline \multirow[t]{2}{*}{ Espessurn } & adoquado & ESP & $-0,38$ & -0.04 & 0,02 & 0,00 & 1,41 & 0,02 \\
\hline & insuficiente & ESPO & 1,90 & 0.22 & 0,12 & 0,01 & 7,06 & 0,10 \\
\hline \multirow[t]{2}{*}{ Comprimento } & adequado & COMP & -0.43 & $-0,62$ & 0,02 & 0,17 & 1,27 & 2,63 \\
\hline & insuficiente & COMPO & 0,60 & 0,87 & 0,03 & 0,24 & 1,78 & 3,68 \\
\hline \multirow[t]{2}{*}{ Igual-difereme } & adequado & ID & $-0,31$ & $-0,25$ & 0,01 & 0,03 & 0,77 & 0,47 \\
\hline & insuficiente & IDO & 0,63 & 0,49 & 0,03 & 0,06 & 1.55 & 0,95 \\
\hline Sequência lógico- & adoquado & SLT & $-0,56$ & 0,03 & 0,03 & 0,00 & 1,99 & 0,01 \\
\hline temporal & insuficionte & SLTO & 0,66 & $-0,04$ & 0,04 & 0,00 & 2,35 & 0,01 \\
\hline \multicolumn{9}{|c|}{ Desemvolvimento fonèmico } \\
\hline \multirow[t]{2}{*}{ Descripio fonémica } & adequado & DF & $-0,31$ & 0,18 & 0,01 & 0,02 & 0,76 & 0,25 \\
\hline & insuficiente & DFO & 0.59 & $-0,34$ & 0.03 & 0,03 & 1,43 & 0,47 \\
\hline Caracteristicas da & adequado & CF & -0.28 & 0.16 & 0,01 & 0,01 & 0,64 & 0.22 \\
\hline fala & insuficiente & CFO & 0,66 & $-0,38$ & 0,03 & 0,03 & 1,52 & 0,51 \\
\hline \multirow{3}{*}{$\begin{array}{l}\text { Produção Oral } \\
\text { Narrativas orais }\end{array}$} & & & & & & & & \\
\hline & adequado & NO & -0.30 & 0,08 & 0,01 & 0.00 & 0,73 & 0.05 \\
\hline & insuficiente & NOO & 0,67 & $-0,17$ & 0.03 & 0,01 & 1,63 & 0,11 \\
\hline
\end{tabular}

(1) adequado = proporção de pontos no tema; insuficiente $=$ proporção de pontos restantes para atingir a pontuação máxima no tema.

Fonte: Dados da Pesquisa. 
$\mathrm{Na}$ Tabela 5 encontramos as coordenadas das crianças e as suas inércias parciais e relativas dentro de cada eixo principal.

Tabela 5. Códigos, coordenadas, inércias parciais e relativas nos dois primeiros eixos principais das crianças, segundo os grupos com ingresso recente na creche (igual ou menor há 6 meses) e com 4 anos ou mais de acompanhamento.

\begin{tabular}{|c|c|c|c|c|c|c|c|}
\hline \multirow[b]{2}{*}{ Grupo(1) } & \multirow[b]{2}{*}{ Crianças } & \multicolumn{2}{|c|}{ Coordenadas } & \multicolumn{2}{|c|}{ Contribuiçāo parcial } & \multicolumn{2}{|c|}{$\begin{array}{l}\text { Contribuiçāao } \\
\text { relativa(\%) }\end{array}$} \\
\hline & & F1 & $\bar{F} 2$ & F1 & $\bar{F} 2$ & F1 & $\overline{F 2}$ \\
\hline 1 & CRT & 1,11 & 0,05 & 0,31 & 0,00 & 17,97 & 0,03 \\
\hline 1 & DLG & 0.52 & $-0,14$ & 0,07 & 0,02 & 4,03 & 0,20 \\
\hline 1 & GS & 0,04 & $-0,58$ & 0,00 & 0,32 & 0,02 & 3,57 \\
\hline 1 & LOBG & 1,06 & 0,08 & 0,29 & 0,01 & 16,49 & 0,07 \\
\hline 1 & TSA & 0,10 & 0,15 & 0,00 & 0,02 & 0,14 & 0,25 \\
\hline 1 & WS & $-0,25$ & $-0,37$ & 0,02 & 0,13 & 0,94 & 1,42 \\
\hline 2 & CMG & $-0,44$ & $-0,09$ & 0,05 & 0,01 & 2,82 & 0,09 \\
\hline 2 & JMP & $-0,36$ & 0,40 & 0,03 & 0,15 & 1,87 & 1,71 \\
\hline 2 & $\mathbf{K A}$ & $-0,50$ & $-0,04$ & 0,06 & 0,00 & 3,71 & 0,02 \\
\hline 2 & NO & $-0,52$ & $-0,05$ & 0,07 & 0,00 & 3,89 & 0,02 \\
\hline 2 & RJSJ & $-0,19$ & 0,60 & 0,01 & 0,34 & 0,51 & 3,78 \\
\hline 2 & TAML & $-0,57$ & $-0,02$ & 0,08 & 0,00 & 4,84 & 0,01 \\
\hline
\end{tabular}

(1)1= crianças com ingresso recente na creche (igual ou menor a 6 meses); 2=crianças com 4 anos ou mais de acompanhamento.

Fonte: Dados da Pesquisa.

Apresentamos em relação aos dois eixos principais, no Gráfico 1 as coordenadas das modalidades segundo o desempenho na formação de conceitos, no Gráfico 2 as modalidades segundo o desempenho no desenvolvimento fonêmico e na produção de narrativas orais. 
Na Figura 10 apresentamos o resumo do desempenho das crianças nos três temas de linguagem reunidos, definindo o eixo principal $F_{1}$.

No Gráfico 3 apresentamos as coordenadas das crianças em relação aos dois primeiros eixos principais e, no Gráfico 4 essas mesmas coordenadas associadas à tipologia dos temas de linguagem, que associadas às inércias parciais e relativas de cada criança, justificam a diferenciação entre os dois grupos na seção a seguir.

\subsubsection{Definiçăo dos Eixos Principais}

A definição dos eixos principais foi abordada em duas fases:

$1^{\text {a) }}$ individualmente por temas (conceituados por subconjuntos de variáveis), através das inércias de suas modalidades; a modalidade que tiver maior inércia em relação à total é a que melhor define o eixo (eventualmente pode ocorrer uma igualdade); e,

$\left.2^{a}\right)$ através da conceituação proveniente da associação das variáveis (através de suas modalidades) dos diferentes temas, reunindo-se as definições parciais (temática) dos eixos principais. 


\subsection{Definição do Primeiro Eixo Principal $\left(F_{1}\right)$}

A associação entre as modalidades do tema formação de conceitos (com exceção do conceito comprimento), define o eixo principal $F_{1}$, com 20 modalidades (10 mostrando o desempenho adequado e 10 o desempenho insuficiente), correspondendo a $72 \%$ da explicação da inércia parcial desse eixo e $40,84 \%$ de contribuição em relação à inércia total.

As modalidades dessas variáveis estão orientadas no sentido positivo-negativo de $F_{1}$, como se observa no Gráfico 1(a). As modalidades, nas quais as crianças apresentaram desempenho adequado têm suas coordenadas no lado negativo do eixo e, no caso do desempenho insuficiente, no lado positivo.

Apresentamos no Gráfico 1(b) a projeção das coordenadas das modalidades sobre o eixo $F_{1}$, mostrando a posição relativa entre elas e a definição desse eixo, segundo a formação de conceitos. 
Gráfico 1. (a) Plano fatorial $F_{1} \times F_{2}$; e, (b) Definição parcial do eixo principal $F_{1}$, segundo 0 desempenho na Formação de Conceitos.

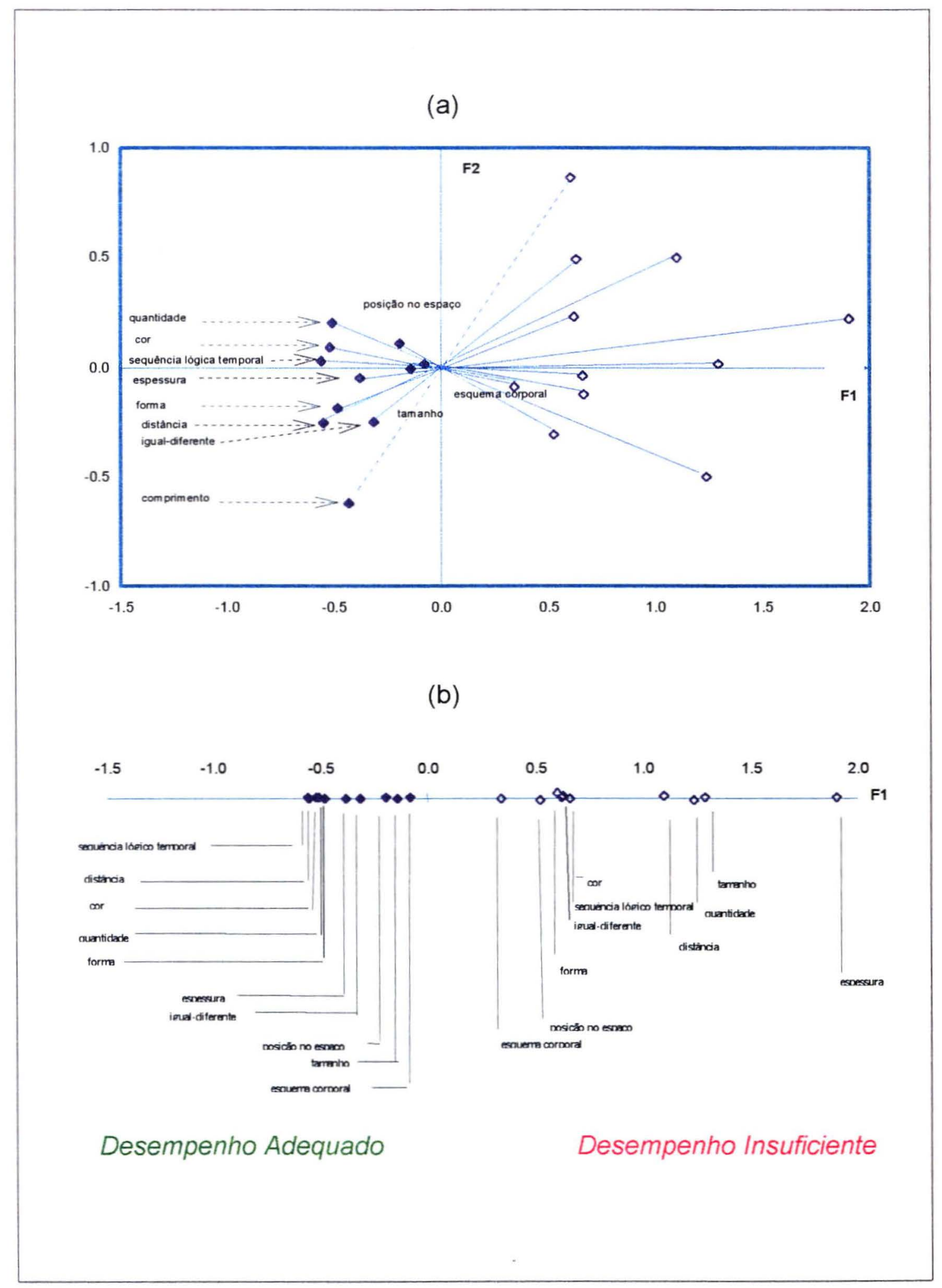

Fonte: Dados da Pesquisa 
As variáveis do desenvolvimento fonêmico, conforme página 66 , contribuiram em $8 \%$ para a inércia parcial desse eixo, e com $4,35 \%$ para a inércia total. Como as variáveis do tema formação de conceitos, as que estão associadas ao desempenho adequado das crianças têm suas coordenadas no lado negativo do eixo e, em caso contrário, no lado positivo

A produção de narrativas orais, como os outros dois temas, associa o bom desempenho das crianças ao lado negativo do eixo e o desempenho insuficiente ao lado positivo. Suas modalidades explicam $4 \%$ da inércia parcial e contribuem com $2,36 \%$ para a inércia total.

Observamos no Gráfico 2(a) a posição dessas variáveis em relação aos dois primeiros eixos principais e, no Gráfico $\mathbf{2 ( b )}$ como as mesmas definem o eixo $F_{1}$ segundo o desenvolvimento fonêmico e a produção de narrativas orais

O eixo principal $F_{1}$, portanto, é definido pela formação de conceitos (com exceção do conceito comprimento), desenvolvimento fonêmico e produção de narrativas orais. As modalidades dessas variáveis estão orientadas no sentido positivo-negativo de $F_{1}$. O lado negativo corresponde ao desenvolvimento adequado da linguagem e, o lado positivo, ao desenvolvimento insuficiente da linguagem.

Resumimos na Figura 10 a projeção das coordenadas das modalidades dos três temas de linguagem, mostrando que o desenvolvimento da linguagem tem seu gradiente orientado no sentido positivo-negativo de $\mathrm{F}_{1}$, definindo-o 
Gráfico 2. Plano fatorial $F_{1} \times F_{2}$; e, (b) Definição parcial do eixo principal $F_{1}$, segundo o desempenho no Desenvolvimento Fonêmico e na Produção Oral.

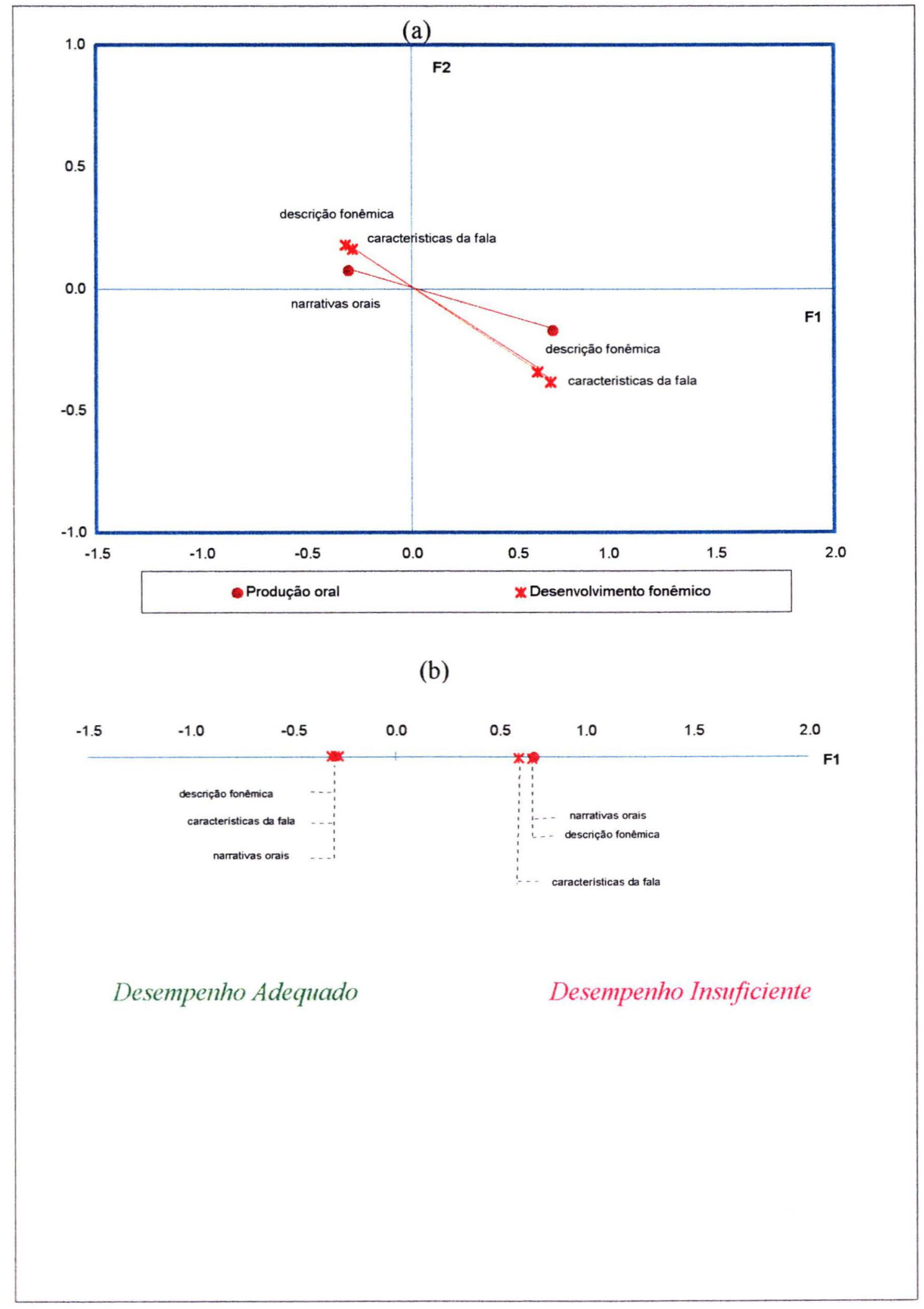

Fonte: Dados da Pesquisa 
Figura 10. Definição parcial do eixo principal $F_{1}$ - Gradiente do Desenvolvimento da Linguagem.

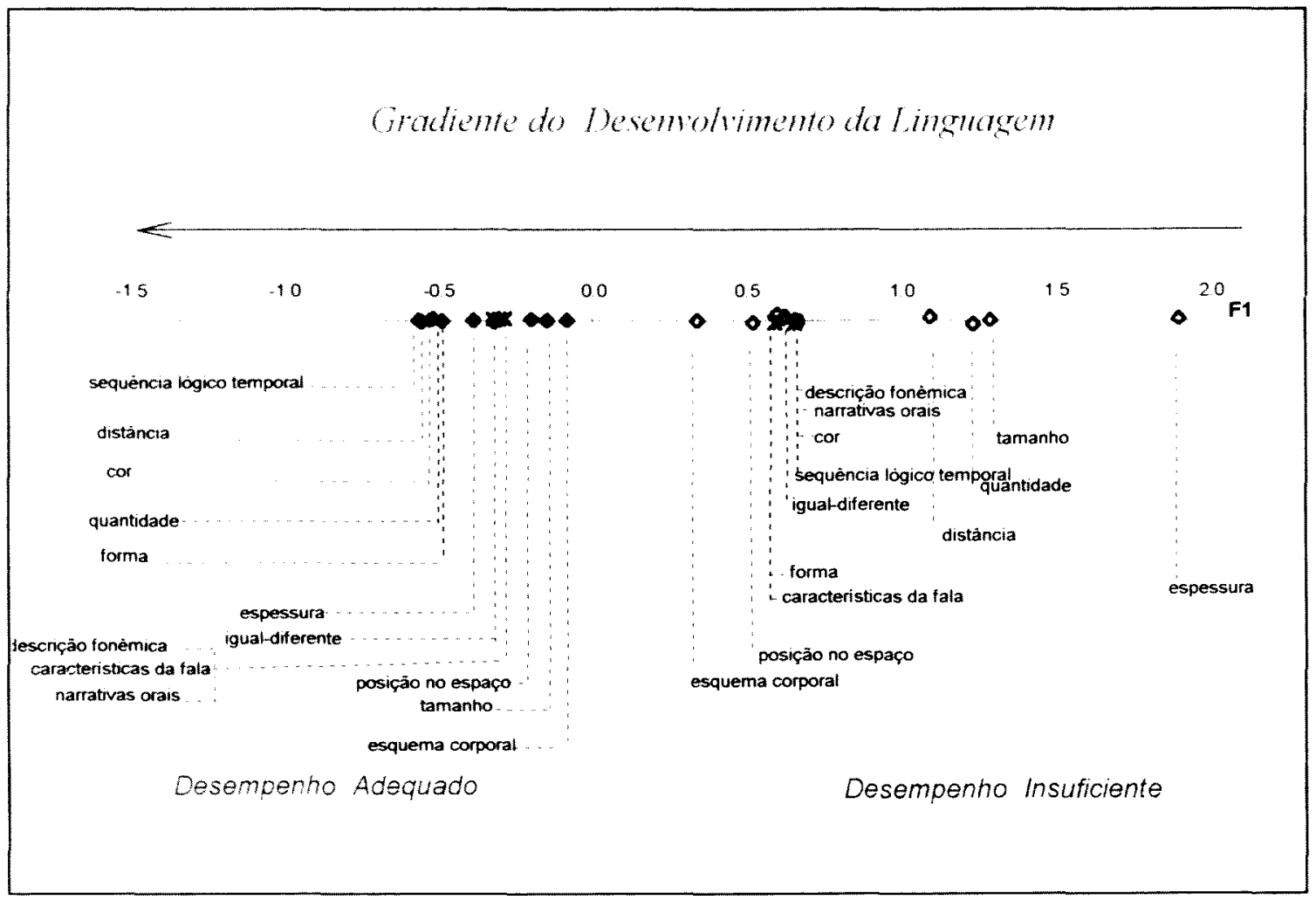

Fonte: Dados da Pesquisa

\subsection{Definição do Segundo Eixo Principal $\left(F_{2}\right)$}

A formação do conceito comprimento define especificamente, o eixo principal $F_{2}$, explicando $41 \%$ da inércia parcial desse eixo e contribuindo com $6,31 \%$ para a inércia total. 
Podemos observar o comportamento das coordenadas de suas modalidades no Gráfico 1(a) representadas e unidas por uma linha pontilhada. O lado positivo corresponde à ausência desse conceito e o negativo a sua presença.

O eixo principal F2 mostra a variabilidade de resultados, no conceito de comprimento, apresentada pelas crianças com tempo diferenciado de acompanhamento na creche, demonstrando que a presença desse conceito não está associada diretamente ao gradiente do desenvolvimento da linguagem, apresentado pelo primeiro eixo principal.

Como descrevemos na seção seguinte, há algumas crianças com bom desenvolvimento de linguagem e ausência da formação do conceito de comprimento ou, de modo contrário, com baixo desenvolvimento de linguagem e presença da formação do conceito de comprimento.

\subsubsection{Tipologia das Crianças e dos seus Desempenhos}

No Gráfico 3 apresentamos as coordenadas das crianças dos grupos $6 m$ e $4 a$ no plano fatorial e a definição parcial do eixo principal $F_{1}$, segundo o gradiente de desenvolvimento da linguagem e a diferenciação do tempo de acompanhamento de crianças na creche. 
No Gráfico 4 apresentamos essas mesmas coordenadas em relação à tipologia dos três temas de desenvolvimento da linguagem descrita na seção anterior.

$\mathrm{Na}$ Figura 11 apresentamos a definição geral do eixo principal $F_{1}$, em relação ao gradiente de desenvolvimento da linguagem associado à diferenciação entre o tempo de acompanhamento das crianças na creche, com as coordenadas das modalidades que o definem.

\subsubsection{Crianças com Ingresso Recente (igual ou menor há 6} meses)

Observamos nos Gráficos 3(a) e 3(b) que as coordenadas que representam as crianças com ingresso mais recente na creche estão posicionadas na sua maioria no lado positivo de $F_{1}$. Com a interpretação das inércias parciais e relativas das crianças e da posição de suas coordenadas em relação aos dois eixos caracterizamos as crianças desse grupo, como segue.

As contribuições, relativas à inércia total, correspondentes às crianças CRT e LOBG $(17,97 \%$ e $16,49 \%$, respectivamente) e os valores positivos de suas coordenadas em $F_{1}$, estão correlacionadas ao desenvolvimento da linguagem insuficiente mais extremo. Enquanto DLG apresenta uma inércia 
relativa de $4,03 \%$ e coordenada positiva neste eixo, portanto mostra um desenvolvimento da linguagem insuficiente menos intenso, que 0 das duas crianças anteriores. As crianças TSA e GS apresentam coordenadas positivas em $F 1$, mas bem próximas do ponto zero, com inércias relativas baixas, isto é, $0,14 \%$ e $0,02 \%$, respectivamente.

Esse resultado nos leva a concluir um comportamento médio em relação ao desenvolvimento da linguagem, nos três temas. A diferenciação entre estas duas crianças está na formação do conceito de comprimento mostrada no eixo principal $F_{2}$. $O$ lado positivo de $F_{2}$ corresponde à ausência desse conceito e o negativo a sua presença. As inércias relativas e as coordenadas destas duas crianças, em $F_{2}$, foram $1,42 \%$ e $3,57 \%$, positiva e negativa, respectivamente. Por sua vez, a criança WS tem coordenadas negativas nos eixos $F_{1}$ e $F_{2}$ e inércias relativas $0,94 \%$ e $1,42 \%$, respectivamente. Isto quer dizer que, em relação a $F_{2}$, a criança apresenta 0 conceito de comprimento e, em relação a $F_{1}$, quanto à formação dos demais conceitos está próximo das pontuações máximas. Além disso, apresenta comportamento médio em relação ao desenvolvimento fonêmico e produção de narrativas orais. 


\subsubsection{Crianças com 4 anos ou mais de acompanhamento}

As crianças com mais tempo de acompanhamento na creche estão posicionadas no lado negativo $F_{1}$, como podemos observar nos Gráficos 3(a) e 3(b).

As contribuições relativas à inércia total no eixo $\mathrm{F} 1$, correspondentes às crianças TAML, KA, NO e CMG $(4,84 \%, 3,89 \%, 3,71 \%$ e $2,82 \%$ respectivamente) estão associados ao desenvolvimento de linguagem mais adequado, entre todas as crianças. A criança CMG se diferenciou deste grupo apenas pelo desempenho menor na formação do conceito cor $(33 \%$, conforme Tabela 1). A criança JMP contribui à inércia total do eixo $F_{1}$ com $1,87 \%$ e à inércia total do eixo $F_{2}$ com $1,71 \%$. Essa criança tem um bom desempenho no desenvolvimento de linguagem com ausência da formação do conceito de comprimento. E finalmente, a criança RJSJ contribui à inércia total do eixo $F_{1}$ com $0,51 \%$ e à inércia total do eixo $F_{2}$ com $3,78 \%$. Apresenta o mesmo desempenho de linguagem que JMP, também com a ausência da formação do conceito de comprimento, acrescido da ausência da formação do conceito de distância e, menor desempenho da formação no conceito forma ( $50 \%$, conforme Tabela 1$)$. 


\subsubsection{Diferenciação do tempo de acompanhamento de crianças} na creche

Resumindo, observamos no Gráfico 4 que é uma complementação do Gráfico $3 \mathrm{com}$ as modalidades dos temas de linguagem, que as crianças com menos tempo de acompanhamento na creche têm um menor desenvolvimento de linguagem do que as com maior tempo. 0 desenvolvimento destas crianças segue o gradiente de desenvolvimento da linguagem que definiu o eixo principal $F_{1}$ e que concluimos apresentando a Figura 11.

Com isso, embora não seja possivel fazer inferências na comparação entre os dois grupos de crianças, pelo tamanho da amostra disponivel, este estudo mostra que há indicios de que as crianças com $6 \mathrm{~m}$ e as com $4 a$ diferem quanto ao desenvolvimento da linguagem. 
Gráfico 3. (a) Plano fatorial $F_{1} \times F_{2}$, segundo as coordenadas das crianças com 6 meses ou menos e, das crianças com 4 anos ou mais de acompanhamento na creche; e, (b) Definição parcial do eixo principal $\mathrm{F}_{1}$ - Gradiente do Desenvolvimento da Linguagem x Diferenciação do tempo de acompanhamento de crianças na creche.

(a)

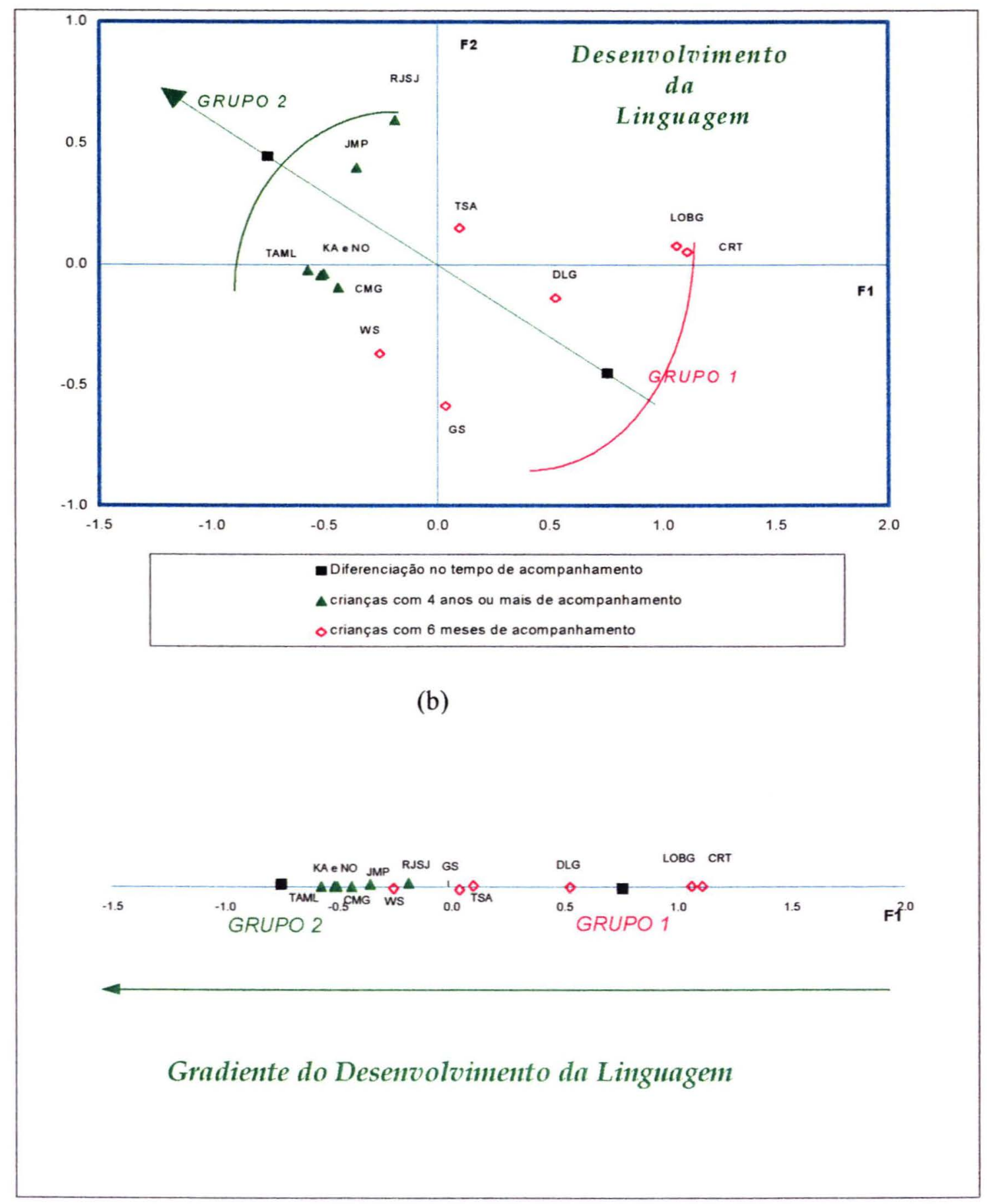

Fonte: Dados da Pesquisa 
Gráfico 4. Plano Fatorial $F_{1} \times F_{2}-$ Formação de Conceitos, Desenvolvimento Fonêmico e Produção de Narrativas Orais associados à diferenciação do desenvolvimento da linguagem, segundo o tempo de acompanhamento de crianças na creche.

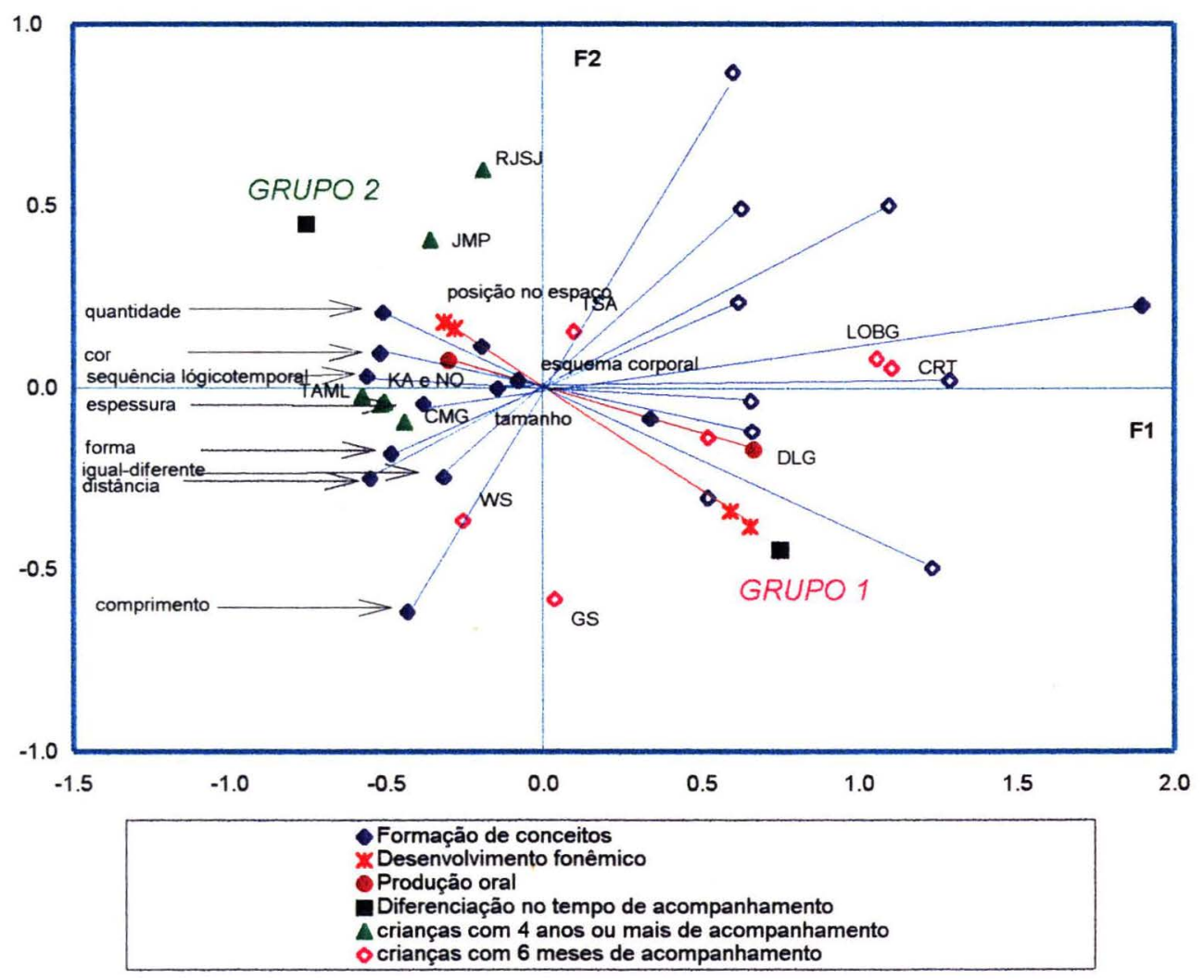

Fonte: Dados da Pesquisa 
Figura 11. Definição geral do eixo principal $F_{1}$ - Gradiente do Desenvolvimento da Linguagem x Diferenciação do tempo de acompanhamento de crianças na creche.

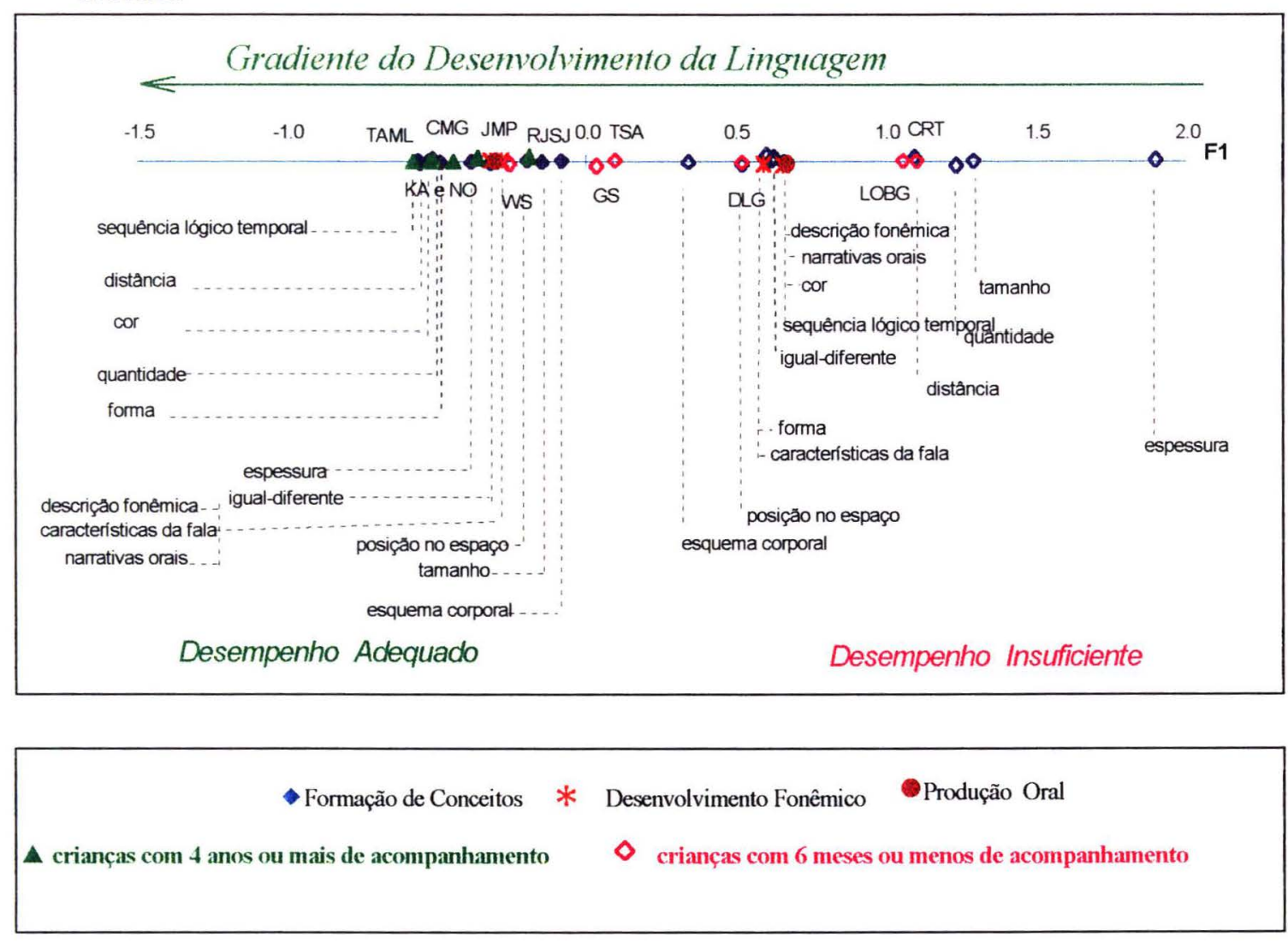

Fonte: Dados da Pesquisa 
5. DISCUSSÃO 
Neste capitulo apresentamos as discussōes sobre os resultados encontrados na descrição do uso funcional da linguagem oral de crianças com tempos diversos de acompanhamento, isto é, com seis meses ou menos e quatro anos no contexto de uma creche, salientando que a assistência a essas crianças foi realizada por auxiliares de desenvolvimento infantil previamente treinadas.

Ressaltamos, num primeiro momento, que as estratégias escolhidas para compor o roteiro norteador por meio do qual foi possivel realizar a descrição da linguagem oral na creche em estudo, estavam harmonizadas com a faixa etária das crianças, ou seja, 4a e $1 \mathrm{~m}$ a $5 \mathrm{a}$ e $4 \mathrm{~m}$, e com os propósitos de atendimento estabelecidos no planejamento da instituição.

A interação com cada criança, com o grupo de crianças, com as ADI e com a própria instituição foi determinante na realização da descrição do uso funcional da linguagem. Além disso, a escolha e utilização de materiais concretos já incorporados ao cotidiano das crianças e o ambiente escolhido proporcionaram condições favoráveis às manifestações de linguagem.

A seguir apresentamos algumas reflexões sobre os resultados encontrados nas características gerais e no estudo das associações entre os temas de linguagem, o tempo de acompanhamento e o desenvolvimento de linguagem no contexto dessa creche. 


\subsection{CARACTERISTICAS GERAIS}

\subsubsection{Formação de Conceitos}

Os resultados encontrados demonstram que as crianças do grupo de maior tempo de acompanhamento na creche (4a) apresentam melhor desempenho no tema de linguagem formação de conceitos do que as crianças do grupo com ingresso mais recente $(6 \mathrm{~m})$

Entre as crianças do grupo $6 \mathrm{~m}$, três delas (WS, GS e TSA) obtiveram desempenhos acima da média, realizando as atividades propostas sem muitas dificuldades, enquanto que as outras três crianças (DLG, CRT e LOBG) apresentaram desempenhos considerados muito baixos para a idade. As variáveis - forma, distância, quantidade, espessura, comprimento, igual-diferente e seqüência lógico-temporal - foram as que geraram maiores dificuldades para estas crianças.

Comportamento muito diferente foi manifestado pelas crianças do grupo $4 a$, as quais obtiveram desempenhos muito satisfatórios. Duas crianças desse grupo não mostraram terem incorporados a noção de comprimento (JMP e RJSJ) e a noção de distância (RJSJ).

Os achados da pesquisa realizada por BRAZ, PELLICCIOTTO (1988) indicaram que os conceitos referidos acima são conhecidos por volta dos 5 anos de idade, exceção feita às articulações do corpo (esquema corporal) e noção de tamanho (maior/menor) que são conhecidas por volta 
dos 7 anos. As crianças de ambos os grupos apresentaram as noções de esquema corporal e tamanho contrariando as constataçōes da pesquisa citada.

As experiências vividas na rua, as brincadeiras como subir em árvores, escalar muros, soltar pipas, ou seja, a maneira como a criança interage com a sua circunstância e abrangência, fazem supor constituírem fatores sugestivos da presença da noção de altura em todas as crianças, independentemente do contexto educacional institucionalizado. As demais noções sugerem a necessidade da exposição das crianças a atividades educativas facilitadoras.

O processo de formação de conceitos pressupōe, segundo VYGOTSKI (1989), possibilidades crescentes de abstração, comparaçōes, diferenciações, atenção, percepção, possibilidades de evolução das funções psicológicas superiores, isto é, funçōes que se modificam ao longo do desenvolvimento das crianças.

Quanto à ordenação de figuras em seqüência, as seis crianças do grupo $6 \mathrm{~m}$ apresentaram um desempenho insuficiente na organização de quatro figuras, não conseguindo ordená-las nem colocá-las em seqüência.

A possibilidade de ordenar logicamente ações e fatos, numa perspectiva temporal e causal, sugere a aquisição do conceito de tempo e de estabelecer relações causais nas atividades diárias desenvolvidas pelas crianças (PIAGET, 1976; SEBER, 1995). 
A utilização dos conceitos cognitivos no periodo inicial de desenvolvimento é realizada por meio de simples repetições que são executadas pelas crianças com certa facilidade, porém sem significados precisos.

A incorporaçāo desses significados só evoluirá à medida que as classificações, as diferenciações e o reconhecimento de semelhanças sejam vivenciados pelas crianças.

Neste sentido, GUEDES (1995) argumenta que as noções cognitivas internalizadas se desenvolvem a partir das sensações e percepções sentidas pelas crianças e paulatinamente vão sendo memorizadas e traduzidas pela linguagem.

Acrescenta a autora que a internalização desses processos são codificados lingüisticamente e proporcionam às crianças a comparação de grandezas, a identidade de semelhanças, a identificação de posição espacial e temporal, possibilitando alternativas variadas de solução de problemas e desafios pelos quais se deparam no seu cotidiano de desenvolvimento.

A formação de conceitos, portanto, pode ser considerada como uma construção efetiva que evolui gradativamente no decorrer das interações que a criança realiza com a sua circunstância. 


\subsubsection{Desenvolvimento Fonêmico}

Os resultados encontrados na descrição do desenvolvimento fonêmico apontam que as crianças com maior tempo de acompanhamento na creche (4a) apresentam melhores desempenhos do que as crianças do grupo com ingresso mais recente $(6 \mathrm{~m})$.

O desenvolvimento fonêmico apresentado pelas crianças do grupo 4a demonstrou-se adequado. A capacidade fonética dessas crianças se relaciona adequadamente com o sistema padrão do adulto, apresentando todas as crianças desse grupo o inventário fonético completo.

Duas crianças desse grupo, CMG e NO, apresentaram alterações articulatórias à produção oral da linguagem.

CMG manifestando omissão assistemática do fonema $/ r /$ no final da silaba dentro da palavra e no final da palavra; omissão sistemática do fonema // no grupo consonantal /bl/ como em [buzina] para "bluzinha"; omissão sistemática do fonema /r/ no grupo consonantal / $/ \mathrm{r} /$ como em [livu] para "livro" e no grupo consonantal /tr/ como em [estela] para "estrela" ,e substituição sistemática do fonema // por $/ r /$ na realização do grupo consonantal $/ \mathrm{kl} /$ como em [bisikre'ta] para "bicicleta".

E a criança NO que apresentou a omissão sistemática dos fonemas Ir/ e /// na realização de grupos consonantais como nos vocábulos [patu] para "prato", [kwadadu] para "quadrado" e [igezal para "igreja". 
As demais crianças do grupo $4 a$ apresentaram um bom domínio quanto à produção, a organização e a percepção dos sons da fala.

As crianças do grupo $6 \mathrm{~m}$, por sua vez, apresentaram um desempenho insuficiente quanto ao desenvolvimento fonêmico. Cinco das seis crianças $(83,33 \%)$ desse grupo apresentaram o inventário fonêmico incompleto no qual predominaram as ausências dos fonemas fricativos $/ f /,|\mathrm{V} /,| \mathrm{s} /, \mid \mathrm{z}$; dos fonemas africados $|J|,|\xi|$ e dos fonemas líquidos $I I, / r /$ e $I N$. Observou-se também a ausência da realização dos grupos consonantais predominantemente no inicio e meio da palavra, particularmente os grupos constituidos por consoante mais os fonemas $/ \mathrm{r} / \mathrm{e} / \mathrm{I}$.

A descrição das caracteristicas articulatórias dessas crianças evidenciou a presença de alteraçōes nos traços distintivos de sonoridade /b/

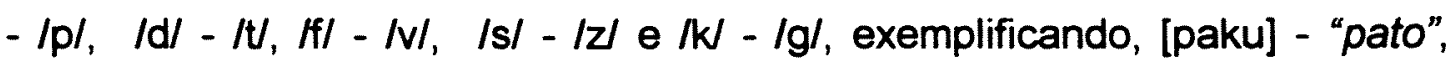
[kapelu] - "cabelo", [voku] - "fogo", [kasa] - "casa" e no ponto e modo de articulação, com omissões sistemáticas dos fonemas $/ \mathrm{r} /$, /R/, e /I/ como em [pد'ta] - "porta", [kajsa] - "carroça" e [eãw] - "leão", e assistemáticas dos fonemas $/ R /,|r /|$,$s / como em [a'dyu] - "rádio", [abãw] - "sabão" e$ substituições sistemáticas do fonema / $\mathrm{r} /$ pelo fonema /// como em [agว'la] "agora", e assistemáticas do fonema /s/ pelo fonema /t/ como em [tapu] "sapo".

As características dos achados acima descritos e a faixa etária das crianças, 4 anos e 1 mês a 5 anos e 4 meses, podem sugerir que a produção oral das crianças com seis meses ou menos de acompanhamento 
possa ser decorrente do contexto sócio-cultural-lingüistico no qual as crianças se desenvolveram até o ingresso na creche. Fato este não observado nas crianças com maior tempo de acompanhamento na creche.

Os seguintes estudos dão sustentação as hipóteses acima sugeridas, LAUNAY, BOREL-MAISONNY, (1979); ISSLER, (1983); CIGANA e col, (1995); ANDRADE, (1997); BITTAR, (1997) e GUEDES, (1997). Esses autores referem em seus trabalhos que as interferências de um ambiente pouco estimulador, da ausência de bons modelos lingüisticos e da não formação do hábito de verbalizar pela restrição do convívio social diferenciado podem provocar alteraçōes significativas no desenvolvimento fonêmico das crianças.

Quanto às características da fala não foi observada a presença de hábitos orais viciosos nas crianças do grupo $4 a$, ao contrário das crianças do grupo 6m, (LOBG, GS e CRT ) que apresentaram respectivamente o uso da chupeta, a sucção digital do dedo polegar e o hábito de roer as unhas.

A presença dos hábitos viciosos orais desenvolveu nessas crianças deformidades de oclusão, mordida aberta, interposição de língua, respiração bucal (GS e CRT); musculatura labial superior hipotônica e musculatura labial inferior hipertônica (LOBG) e alterações na produção da fala (LOBG, GS e CRT). 


\subsubsection{Produção de Narrativas Orais}

O desempenho das crianças do grupo 4a na produção de narrativas orais mostrou-se mais eficiente e adequado para a idade do que o desempenho das crianças do grupo $6 \mathrm{~m}$.

Duas crianças do grupo 6m (TSA e GS) manifestaram desempenhos semelhantes às do grupo $4 a$, fato que nos leva a pensar que estas crianças possam ter vivenciado experiências lingüisticas mais ricas e ambientes mais estimuladores antes de ingressarem na creche.

As seguintes características foram encontramos nas narrativas orais das demais crianças (WS, LOBG, CRT e DLG) com tempo de acompanhamento de seis meses ou menos: descrição das diferentes figuras, somente parte dos eventos foram referidos, falta de coesão entre as partes da narrativa (fragmentação da narrativa), eliciação da narrativa executada pela ADI que por meio de perguntas e respostas uma situação a ser narrada vai se configurando, estruturas coordenadas reduzidas, presença de supergeneralizações, uso predominante de palavras de conteúdo como substantivos e verbos, não manutenção temática da narrativa, não ordenação linear dos elementos na narrativa, presença de marcadores conversacionais não-lingüisticos. Constatamos na análise de algumas narrativas a preferência em contarem as suas próprias histórias em detrimento das propostas oferecidas. 
As narrativas orais produzidas pelas crianças com maior tempo de acompanhamento na creche apresentaram como caracteristicas gerais, a ordenação temporal dos eventos com a compatibilidade entre a ordenação de figuras e o relato, eliciação das narrativas realizada pelas próprias crianças, acréscimo às narrativas de experiências vivenciadas pelas próprias crianças em contextos semelhantes ao tema ou completamente diferentes, maior autonomia na elaboração das narrativas, presença de orações coordenadas completas, manutenção da temática das narrativas, acréscimo de personagens e presença de produções muito criativas.

Comparando o desenvolvimento fonêmico e a produção de narrativas orais constatamos que as crianças que utilizam melhor a fala são aquelas que também tiveram melhores desempenhos no uso morfossintático e semântico da linguagem. Este achado também foi encontrado nos resultados das investigaçōes com crianças de 3 a 6 anos de idade realizada por GUEDES (1997).

PERRONI (1992) encontrou em seu trabalho sobre o discurso oral, que em torno dos cinco anos as crianças já demonstram saber que a narrativa tem uma estrutura peculiar e que a ordenação temporal e causal dos eventos é necessária para dar sustentação às narrações que criam ou reproduzem.

A autora acima citada continua enfocando que a capacidade de narrar pode ser vista como construção da criança, que aos poucos vai assumindo 
seu lugar na comunidade lingüistica, inicialmente com os pais e depois com as funcionárias da creche na qual é inserida.

As narrativas abrem para as crianças a possibilidade de construir outros universos de referência, aos quais só se tem acesso por meio da linguagem (SIQUEIRA, 1991; AZCOAGA, 1992; PERRONI, 1992; GUEDES, 1997).

Neste sentido não podemos deixar de reconhecer que a produção de narrativas orais representa para a criança uma das e, talvez, a mais importante experiência lingüistica que the possibilita manter uma nova relação com a linguagem na interação com a sua circunstância.

Os resultados sugeriram que no contexto dessa creche, as crianças desenvolveram a linguagem de maneira diferente. Isto é, todas as crianças que apresentaram tempo de acompanhamento de quatro anos manifestaram um desenvolvimento adequado ou suficiente para a idade, enquanto quatro crianças $(83,33 \%)$ com tempo de acompanhamento de seis meses ou menos demonstraram um desenvolvimento de linguagem insuficiente para a idade.

A possivel diferenciação no desenvolvimento de linguagem das crianças com tempos distintos de acompanhamento nesta creche ficou evidenciada na maior ou menor variabilidade de respostas adequadas ao uso funcional da linguagem.

Depreendemos que as respostas às percepções dos temas de linguagem das crianças do grupo $6 \mathrm{~m}$ se manifestaram mais heterogêneas, enquanto as respostas das crianças do grupo $4 a$ revelaram-se mais 
homogêneas, sugerindo que no contexto dessa creche existe uma estreita relação entre o acompanhamento realizado pelas $A D I$, previamente treinadas, e o desenvolvimento da linguagem das crianças assistidas.

\subsection{ESTUDO DA ASSOCIAÇÃO DOS TEMAS DE LINGUAGEM E O} TEMPO DE ACOMPANHAMENTO NA CRECHE

A análise de correspondência múltipla dentro da metodologia estatística empregada permitiu identificar que os temas de linguagem como a formação de conceitos, o desenvolvimento fonêmico e a produção de narrativas orais estão diretamente associados ao desenvolvimento da linguagem oral nas crianças da creche.

Quando analisamos a tipologia dos temas de linguagem verificamos que as associaçōes entre as suas variáveis, resumidamente, definem o eixo principal $F^{1}$. As coordenadas das variáveis envolvidas estão orientadas no sentido positivo-negativo de $\mathrm{F}^{1}$, evidenciando que as projeçōes dessas coordenadas refletidas no lado negativo correspondem ao desempenho adequado e as projeções refletidas no lado direito, ao desempenho insuficiente.

Quando interpretamos a tipologia do desempenho das crianças, observamos que as projeçōes das coordenadas das crianças do grupo $4 a$ 
se manifestam no lado negativo do eixo $\mathrm{F}^{1} \mathrm{e}$ as projeções das coordenadas das crianças do grupo $6 \mathrm{~m}$ aparecem no lado direito do eixo $F^{\prime}$. Essas projeções revelam a disposição, no eixo $\mathrm{F}^{1}$, mais concentrada das crianças do grupo 4a mostrando a caracteristica homogênea desse grupo quanto às percepções das variáveis de linguagem, enquanto o comportamento mais heterogêneo das percepções dos temas de linguagem está demonstrado nas projeçōes mais dispersas no eixo $F^{1}$ das crianças do grupo $6 \mathrm{~m}$.

Podemos concluir pela análise dos dados que, nesta creche, as crianças com $4 a$ e as crianças com $6 \mathrm{~m}$ de acompanhamento diferem quanto ao desenvolvimento da linguagem oral.

O desenvolvimento da linguagem das crianças observadas está definido e tem o seu gradiente orientado no sentido positivo-negativo do eixo $F^{1}$

Estas reflexōes levam-nos a considerar que as crianças com ingresso recente $(6 \mathrm{~m})$ estão ainda em adaptação à creche e que a incorporação do cotidiano coletivo compartilhado com outras crianças e adultos requer um tempo de vivência, de amadurecimento na incorporação dessa nova circunstância; ao passo que as crianças com maior tempo de acompanhamento (4a) já estão adaptadas à creche e o seu processo de crescimento e desenvolvimento foi acompanhado de perto por pessoas capacitadas e orientadas a fornecerem uma assistência diferenciada.

No contexto dessa creche, o impacto do tempo de acompanhamento e o atendimento realizado por auxiliares de desenvolvimento infantil 
previamente treinadas, mostraram-se fatores importantes na construção do desenvolvimento da linguagem oral dessas crianças. 
6. CONSIDERAÇÕES FINAIS 
A complexidade do tema escolhido sugere, por si, inúmeras possibilidades de interpretação. Nessa pesquisa procuramos mostrar a vivência da atuação junto a uma creche pública onde desenvolvemos atividades de promoção e prevenção na área da Fonoaudiologia voltadas ao acompanhamento do desenvolvimento da linguagem oral em crianças.

A preocupação pela descrição minuciosa do contexto creche, presente neste trabalho, vem ao encontro do que BRONFENBRENNER (1996) atribui às características do meio ambiente, como fatores que influenciam o desenvolvimento das crianças.

Reiterando as afirmaçōes de BRONFENBRENNER mostraram-se efetivas as avaliaçőes, realizadas por meio da análise do discurso, dos treinamentos oferecidos às ADI oportunizando condiçōes favoráveis para o desenvolvimento das crianças.

As especificaçōes oferecidas pela metodologia estatistica utilizada para a análise dos dados qualitativos, ou seja, a análise de correspondências múltiplas, permitiu identificar que existe uma associação entre o desenvolvimento da linguagem oral e o tempo de acompanhamento de crianças nesta creche.

A constatação resultante da análise de que o desenvolvimento da linguagem oral apresenta um gradiente evidencia a singularidade de cada criança.

O grupo de 4 anos de acompanhamento apresentou melhores desempenhos. Essas crianças no contexto dessa creche apresentaram predominância do uso da oralidade, provavelmente em decorrência de 
vivências e experiências mais significativas com os adultos, outras crianças e com o seu ambiente.

A relevância da atuação especializada dos adultos, nessa creche, mostra que podem agir como multiplicadores de ações de promoção e prevenção fonoaudiológicas, portanto podemos reconhecê-los como agentes facilitadores do desenvolvimento, ou seja, parceiros do desenvolvimento dessas crianças.

A respeito dessa colocação, vale ressaltar que, embora o adulto tenha um papel importante na construção da linguagem infantil, essas crianças deverão ser vistas como seres organizados e competentes, capazes de se adaptarem às exigências de cada fase da vida.

Hoje, as creches possuem uma função essencial e o impacto que geram sobre as familias e a sociedade em geral pode ter uma conseqüência muito mais profunda do que quaisquer efeitos diretos para o desenvolvimento dos seres humanos nas sociedades modernas industrializadas (BRONFENBRENNER, 1996).

Neste sentido a creche constitui campo de atuação extremamente rico ao atendimento fonoaudiológico, na medida que o seu foco de atenção é a linguagem, a qual pode ser entendida como expressão do desenvolvimento da criança.

Atualmente, a Fonoaudiologia nos contextos de saúde pública e educação vêm desenvolvendo ações consideradas de caráter preventivo que parecem sugerir certas limitações. 
A utilização, por exemplo, de triagens em contextos educacionais, cuja função, mais do que prevenir patologias da comunicação, tem sido a de detectar o mais precocemente possivel alteraçōes de linguagem, fala, audição ou motricidade oral, requer estar sendo repensada. Pouco se pensa em interpretar os dados coletados nas triagens como insumos para organização de estratégias efetivas de promoção e prevenção fonoaudiológicas.

Em decorrência desse fato, observamos em serviços públicos de saúde a existência de grande demanda de encaminhamentos ao Setor de Fonoaudiologia de creches, pré-escolas e escolas para a avaliação e terapia dos distúrbios da comunicação.

Havendo poucos fonoaudiólogos na rede básica de saúde, grande parte desses encaminhamentos fica em enormes filas de espera, sem perspectiva de um atendimento que garanta a sua resolubilidade.

Promover contextos que desenvolvam potencialidades, planejando programas que tenham por finalidade otimizar o desenvolvimento de linguagem nos aspectos qualitativos e quantitativos devem ser os propósitos de fonoaudiólogos que atuam em instituições na atenção primária à saúde.

O discurso dos fonoaudiólogos está se modificando. Entretanto, em sua prática, observa-se que ainda permanece o mesmo raciocinio de prevenção, deteç̧ão precoce e encaminhamentos de sujeitos reconhecidos como portadores de distúrbios da comunicação.

No contexto da creche, cenário deste estudo, as interações entre os adultos (ADI) e as crianças costumam ocorrer com freqüência e duração 
maiores do que o usual e são de natureza cognitivo-verbal e exploratória. Isso pode estar revelando que a atuação junto a profissionais que nela atuam, trouxe como conseqüência, um impacto importante na qualidade do atendimento e no próprio desenvolvimento das crianças.

A hipótese dessa colocação é que a formação continuada de auxiliares de desenvolvimento infantil propicia paulatinamente a sensibilização do olhar para a linguagem oral como expressão do desenvolvimento da criança.

As ADI, uma vez treinadas, apresentam condições para promover o desenvolvimento da linguagem oral nas crianças, assim como para construirem estratégias de prevenção e identificação das alteraçōes de linguagem.

Constitui um grande desafio para a Fonoaudiologia sensibilizar as direçōes e programar propostas de educação continuada. A inclusão de temas de interesse do fonoaudiólogo no planejamento institucional ocorrerá como uma conseqüência natural.

À medida que os conteúdos de linguagem forem assimilados pelos profissionais da creche, poderão ser reinterpretados em diferentes contextos e, ao mesmo tempo, serem introduzidos progressivamente ao longo do acompanhamento do desenvolvimento das crianças no seu cotidiano. A linguagem oral, portanto, não deve estar separada das atividades prescritas no planejamento, mas integrada nelas. 
A atuaçāo do fonoaudiólogo torna-se ampla e importante. Nas instituições poderá participar do processo de reconhecimento das diferentes comunidades e suas respectivas formas de comunicação.

$\mathrm{Na}$ construçăo da relação entre os funcionários da creche e o fonoaudiólogo, cabe ressaltar o objetivo maior desse conjunto que é o de contribuir para a melhoria da qualidade de vida da população atendida, mediante a conquista de transformações decorrentes da integração das áreas de saúde e educação.

As interações entre o adulto e a criança no universo sociocultural não deverão ser vistas como intenções, mas como condição integrante de uma prática voltada ao acompanhamento do desenvolvimento da linguagem oral.

As conclusões deste trabalho devem ser interpretadas no que se refere às características desse desenvolvimento em crianças da classe social e cultural especificadas no contexto da creche em questão.

Finalizando, essas reflexões acerca da criança, seu desenvolvimento, sua linguagem e a formação de auxiliares de desenvolvimento infantil, não são totalizantes nem conclusivas.

A metodologia estatística utilizada para a análise dos dados qualitativos desta pesquisa mostrou-se efetiva pelo seu mérito e originalidade.

Sugerimos que se realizem outras pesquisas da mesma natureza utilizando-se tal metodologia de análise estatística, buscando identificar o gradiente de desenvolvimento da linguagem oral de crianças em outros contextos. 
As conclusões decorrentes da análise de correspondências múltiplas poderão contribuir no planejamento de ações em promoção na área da Fonoaudiologia nos diversos contextos institucionais.

O desafio de acompanhar o desenvolvimento da linguagem oral não nos coloca apenas diante da criança, mas diante da própria linguagem e de sua significação.

Vivenciar este estudo foi enriquecedor e descrevê-lo foi compartilhar um percurso de trabalho desenvolvido no campo da saúde pública. 
7. CONCLUSÕES 
A partir dos resultados obtidos nesta pesquisa que teve como contexto uma creche que oferece $o$ atendimento especializado e o ambiente estimulador, podemos concluir que:

$\diamond$ As crianças com tempo de acompanhamento há quatro anos na creche apresentaram melhores desempenhos nas percepções dos temas: formação de conceitos, desenvolvimento fonêmico e produção oral de narrativas, do que as crianças de seis meses ou menos de acompanhamento.

$\diamond$ Os temas de linguagem formação de conceitos, desenvolvimento fonêmico e produção de narrativas orais estão concomitantemente associados ao tempo de acompanhamento na creche.

$\diamond$ A metodologia proposta para a análise das associações entre as variáveis envolvidas (análise de correspondências múltiplas) revelou que o desenvolvimento de linguagem das crianças dos dois grupos estudados apresentou um gradiente, cuja orientação se apresentou no sentido positivonegativo do eixo principal $F^{1}$.

$\diamond$ A pesquisa mostrou, portanto, que as crianças com tempos distintos de acompanhamento nesta creche diferenciam-se quanto ao desenvolvimento da linguagem. 
8. REFERÊNCIAS BIBLIOGRÁFICAS 
1. ABRAMOWICZ A, WAJSKOP G. Creches - Atividades para crianças de 0 a 6 anos. São Paulo: Moderna; 1995. 112p.

2. ANDRADE CRF de. Ações Fonoaudiológicas na Saúde Materno Infantil. In: Andrade CRF de, organizador. Fonoaudiologia em berçário normal e de risco. São Paulo: Lovise; 1996.p.25-42. (Atualidades em Fonoaudiologia 1v).

3. Prevalência das desordens idiopáticas da fala e da linguagem em crianças de um a onze anos de idade. Rev. Saúde Pública 1997; 31(5):495-501.

4. ARANTES L. O fonoaudiólogo, este aprendiz de feiticeiro. In: Lier de Vitto MF. Fonoaudiologia: no sentido da linguagem. São Paulo: Cortez; 1994. p. 2-38.

5. AUGUSTO M. Comunidade Infantil - Creches. Rio de Janeiro: Guanabara Koogan S. A; 1985.

6. AZCOAGA JE., BELLO JA., CITRINOVITZ J., DERMAN B., FRUTOS $W M .$, Los retardos del lenguaje en el niño. $5^{a}$ ed. Barcelona: Paidós; 1992.

7. BEFI D, organizador. Fonoaudiologia na atenção primária à saúde. São Paulo: Lovise; 1997. (Atualidades em Fonoaudiologia, 3v).

8. BITTAR ML et al. Características da saúde de crianças atendidas em creches e prevenção dos distúrbios da comunicação. Rev. Saúde Pública 1997; 28(1):46-58. 
9. BRASIL. Ministério da Saúde. Orientação para organização de centro de saúde. Brasília (DF); 1982.

10. BRAZ H A, PELLICCIOTTI THF. Exame de Linguagem TIPITI. $3^{a}$ ed. São Paulo: Gráfica Ed. MNJ Ltda; 1988.

11. BRONFENBRENNER V. A ecologia do desenvolvimento humano: experimentos naturais e planejados. Porto Alegre: Artes Médicas; 1996.

12. CAMPOS MM, ROSEMBERG F. Critérios para um atendimento_em creches que respeita os direitos fundamentais das crianças. Brasilia(DF): MEC/SEF/COEDI; 1995. 40p.

13. CAMPOS DE CARVALHO MI, RUBIANO MRB. Organização do espaço em instituições pré-escolares. In: Oliveira $Z$ de MR., organizador. Educação Infantil: muitos olhares. São Paulo: Cortez; 1994.p.107-130.

14. CAPPELLETTI IF. A Fonoaudiologia no Brasil Reflexőes sobre os seus Fundamentos. São Paulo: Cortez; 1985.

15.CÉSAR CPHAR., MORSELLI A., SILVA II. Prevenção fonoaudiológica em crianças na fase pré-escolar. Cad. Fac. Integr. Săo Camilo. 1995; 1(2): 49-54.

16. Cigana, LB; CeChella, C; MOtA HB; ChIARI, BM. Perfil do desenvolvimento fonológico de crianças de creches da rede municipal de Santa Maria, Rio Grande do Sul, na faixa etária de 4 a 6 anos e 2 meses Ver. Pró-Fono 1995; 7(2):15-20. 
17. COLLAÇO NL. Fonoaudiologia escolar: as origens de uma proposta. In: Ferreira LP., organizador. O Fonoaudiólogo e a Escola. São Paulo: Summus; 1991.

18. CONDEMARÍN M., CHADWICK M., MILICIC N. Maturidade Escolar. Trad. de MHB Nahoum. Rio de Janeiro: Enelivros; 1986.

19. CORDEIRO, G. Da ação à linguagem na interação criança-criança: um processo de construção. São Paulo; 1998. [Tese de Doutorado Pontifícia Universidade Católica - SP].

20.ESCOFIER B., PAGĖS J. Analyses factorielles simples et multiples. Objectifs, méthodes et interpretation. Paris: Dunod, 1988. 241p.

21. EVERITT B. Cluster Analysis. $2^{a}$ ed. New York: Jonh Wiley \& Sons Inc.; 1981. 139p.

22. FARIA AR de. O Pensamento e a Linguagem da Criança segundo Piaget. $2^{a}$ ed. São Paulo: Ática; 1994. 80p.

23. FREIRE RM. A linguagem como processo terapéutico. São Paulo: Plexus; 1994.

24. GALLARDO JSP. Modelos de atuação do Profissional de Creche. São Paulo; 1993. [Tese de Doutorado - Instituto de Psicologia da USP].

25. GAYOTTO MLC, LANGER RJ, CAMPOS MAF, HÜLLER LT, GURBANOV GD de, BICHARA MAAC, et al. Creches: Desafios e 
contradições da criação coletiva da criança pequena. São Paulo: Ícone; 1992. 134p.

26. GEIS RM. Criar ou Educar Crianças? Estudo das representações de mães e de educadoras sobre o papel da creche. São Paulo, 1994. [Tese de Doutorado - Instituto de Psicologia da USP].

27.GUEDES ZCF. Uma experiência de atuação acadêmica em fonoaudiologia na escola. Acta AWHO 1984; 3 (suppl. 2): 6-14.

28. Fonoaudiologia e Educação: algumas considerações sobre a sociabilidade da linguagem. In: Vieira RM e colegas. Fonoaudiologia e Saúde Pública. Carapicuiba: Pró-Fono; 1995.p.113-160.

29. A atuação do fonoaudiólogo e seu papel na escola. In: Befi D, organizador. Fonoaudiologia na Atenção Primária à saúde. São Paulo: Lovise; 1997.p.119-37. (Atualidades em fonoaudiologia 3v).

30. HADDAD L. A creche em busca de identidade. $2^{\text {a }}$ ed. São Paulo: Loyola; 1993. 246p. (Coleção Realidade Educacional 9v.).

31. HAGE SR de V. Investigando a linguagem na ausência de oralidade. In Marchezan, IQ, organizador. Tópicos em Fonoaudiologia. São Paulo: Lovise; 1995. 2v.

32. HALLIDAY MK. Learning how to mean. Londres: Eward Arnold; 1975. 
33. HARMANN HH. Modern factor analysis. $3^{a}$ ed. Chicago: The University of Chicago; 1976. 487p.

34. HUBIG DO de C, SCHOCHAT E. Atenção Primária em Audiologia. In: Befi D, organizador. Fonoaudiologia na Atenção Primária à Saúde. São Paulo: Lovise; 1997.p.177-199. (Atualidades em Fonoaudiologia, 3v).

35.IORIO C. Avaliação dos encaminhamentos realizados por professores do ciclo básico para o serviço de fonoaudiologia da Unidade Básica de Saúde de Vila Palmeiras - SP. São Paulo, 1999 [Dissertação de Mestrado - Faculdade de Saúde Pública da USP].

36. ISSLER S. Articulaçăo e Linguagem. Rio de Janeiro: Antares; 1983.

37. KISHIMOTO TM. A préescola em São Paulo. São Paulo: Loyola; 1988.

38. KÖNIG K. Os três primeiros anos da criança. Trad. de K. Glass. São Paulo: Antroposófica; 1987.p. 27-44.

39. LAGROTTA MGM, CÉSAR CPHAR. Creches: falando da fonoaudiologia. In: Marchesan IQ, Bolaffi C, Gomes ICD, ZORZI JL, organizadores. Tópicos em fonoaudiologia. São Paulo: Lovise; 1995.p.401-8. 3v.

40. LAPIERRE A, AUCOUTORIER B. A simbologia do movimento: psicomotricidade e educaçåo. Trad. de M Lewis, Porto Alegre: Artes Médicas; 1986. 88p. 
41. LAUNAY C, BOREL-MAISONNY S. Transtornos del lenguage, la palabra y la voz en el niño. $2^{a}$ ed. Barcelona: Toray-Masson; 1979.p.28. 445p.

42. LEITE DE MORAES MC. Aspectos de saúde na rotina da creche e o papel do cuidador da criança: relato de experiência. Rev. Bras. Cresc. Desenv. Hum. 1997; 7(1): 87-92.

43. LIER MFFA. A Constituição do Interlocutor Vocal. São Paulo, 1983. [Dissertação de Mestrado - Pontifícia Universidade Católica - SP].

44. LORDÉlO $E$ da R. Ambiente e desenvolvimento humano: uma reflexão a partir do contexto creche. São Paulo, 1995. [Tese de Doutorado - Instituto de Psicologia da USP].

45. MACHADO MM. O brinquedo-sucata e a criança. Săo Paulo: Loyola; 1994.

46. MERISSE A, JUSTO JS, ROCHA LC da, VASCONCELOS MS. Lugares da infáncia: reflexōes sobre a história da criança na fábrica, creche e orfanato. São Paulo: Arte \& Ciência; 1997. 96p.

47. MILLER RG Jr. Simultaneous Statistical Inference. New York: Springer - Verlag; 1981.

48. OLIVEIRA Z de MR. Educação Infantil: muitos olhares. São Paulo: Cortez; 1994.

49. OLIVEIRA $Z$ de MR, MELLO AM, VITORIA T, ROSSETTIFERREIRA MC. Creches: crianças, faz-de-conta \& cia. Petrópolis: Vozes; 1992. 
50. OLIVEIRA $Z$ de M R, ROSSETTI-FERREIRA MC. Proposta para o atendimento em creches no município de São Paulo. Histórico de uma realidade. In: Rosemberg $F$, organizador. Temas em destaque: creche. São Paulo: Cortez; 1989.p.21-89.

51. OLIVEIRA $Z$ de MR., ROSSETTI-FERREIRA, MC. O valor da interação criança-criança em creches no desenvolvimento infantil. Cademos de Pesquisa 1993; 87:62-70.

52. ORTEGA Y GASSET J. Em torno a Galileu. Esquema das Crises. Petrópolis: Vozes; 1989. 191p.

53. PEREIRA LD, SANTOS AMS, OSBORN E. Ação preventiva na escola: aspectos relacionados à integração professor e aluno e a comunicação humana. In: Vieira RM. e colaboradores. Fonoaudiologia e Saúde Pública. Carapicuíba: Pró-Fono; 1995.p.163-170.

54.PERRONI MC. Desenvolvimento do Discurso Narrativo. São Paulo: Martins Fontes; 1992.

55.PIAGET J. A equilibraçăo das estruturas cognitivas: problema central do desenvolvimento. Rio de Janeiro: Zahar; 1976.

56. PICOLO TAF. O discurso e a realidade do atendimento de crianças em creches. São Carlos, 1983. [Dissertação de Mestrado - $\mathrm{CECH}$ da UFSCAR]. 
57. PINTO AMM. et al. Fonoaudiologia Educacional junto a um sistema e ensino público. In: Ferreira LP. O Fonoaudiólogo e a Escola. São Paulo: Summus; 1991.

58.POLITICA NACIONAL DE EDUCAÇÃO INFANTIL. Brasilia(DF); MEC/ SEF/COEDI; 1994. 48p.

59.PROPOSTA PEDAGÓGICA E CURRÍCULO EM EDUCAÇÃO INFANTIL: UM DIAGNÓSTICO E A CONSTRUÇÃO DE UMA METODOLOGIA DE ANÁLISE. Brasília(DF); MEC/SEF/COEDI; 1996. $114 p$.

60. PROPOSTA PSICOPEDAGÓGICA DO CADI 34 Jd Elisa Maria; 1998.

61. QUIRÓS JB., GUELER FS. La comunicación humana y su patologia. Buenos Aires: CMl; 1966.

62. ROCHA NMD. Desempenho verbal de pré-escolares: emissão de "tato" face a figuras. São Paulo, 1976 [Dissertação de Mestrado da USP].

63.ROSSETTI-FERREIRA MC, et al. A creche enquanto contexto possivel de desenvolvimento da criança pequena. Rev. Brasil. Cresc. Des. Hum 1994; IV (2): 35-40.

64. RUBIANO MRB. Suportes ambientais e organização social de crianças em creche. São Paulo, 1990. [Tese de Doutorado - Instituto de Psicologia da USP].

65. SAMPAIO VRC. Creches: Atividades desenvolvidas com a criança. Rio de Janeiro: EBM; 1984. 
66. SANCHES EMBCC. Creche: realidade e ambigüidade. São Paulo, 1998 [Tese de Doutorado - Pontifícia Universidade Católica - SP]

67. SAS. Statistical Analysis Systems, version 6.02. North Caroline: SAS Institute Inc; 1986. Disquete 3 1/2.

68. SEBER M da G., LUÍS VLF de F., colaboradora. Psicologia do Pré-Escolar - uma visão construtivista. São Paulo: Moderna; 1995. 272p.]

69. SES. Normas Técnicas para os Centros de Acompanhamento e Desenvolvimento Infantil. São Paulo: Edic; 1992.

70.SIQUEIRA AAF. O nascimento biológico de criança. Ver. Bras. Cresc. Des. Hum 1991; 1:44-53.

71. SMOLKA ALB. Conhecimento e produção de sentidos na escola: a linguagem em foco. Cadernos CEDES 1995; 35:41-9.

72. SOUZA SJE. Linguagem, consciência e ideologia: conversas com Bakhtin e Vigotsky. In: Zilma MR, organizador. A criança e seu desenvolvimento - perspectivas para se discutir a educaçăo infantil. $2^{a}$ ed. São Paulo: Cortez; 1995.p.11-29.

73. SUCUPIRA ACSL. A experiência do Município de São Paulo na atenção à saúde do escolar no período de 1989 a 1992. In: Conceição JAN, coordenador. Saúde do escolar: a criança, a vida e a escola. São Paulo: Sarvier; 1994. 
74. TAMANAHA AC, PERISSINOTO J, PEDROMÓNICO MR. O desempenho comunicativo de crianças de 2 anos a 4 anos de idade: caracterização da atividade lúdica e do comportamento verbal. Temas sobre Desenvolvimento 1999; 7(42):43-51.

75. VASCONCELOS AMS, et al. Estimulação de linguagem em crianças em idade pré-escolar: trabalho preventivo numa populaçăo carente. Anais do I Encontro Nacional de Fonoaudiologia 1982:156-170.

76. VIEIRA RM. Promoção de saúde: concepção, sistematização, consecução. Acta AWHO 1984; 3(Parte 2): 5-15.

77. VIGOTSKY LS. A formaçăo social da mente. $3^{a}$ ed. São Paulo: Martins Fontes; 1989.

78. Pensamento e Linguagem. $6^{a}$ ed. São Paulo: Martins; 1996. 140p.

79.ZORZI JL. Linguagem e aprendizagem. In: Marchesan IQ, Bolaffi C, Gomes ICD, Zorzi, JL, organizadores.Tópicos em Fonoaudiologia. São Paulo; Lovise; 1995:213-28. 3v.

80.WALLON H. Do acto ao pensamento - Ensaio de psicologia Comparada. Lisboa: Moraes; 1966.

81. Psicologia e educação de crianças. Lisboa: Estampa; 1997.

82. YAVAS M., HERNANDORENA CLM., LAMPRECHT RR. Avaliação fonológica da criança - reeducação e terapia. Porto Alegre: Artes Médicas; 1992. 
ANEXOS 
Anexo 1: A creche - contexto desse estudo 
Apresentamos a seguir as informações obtidas por meio da realização do diagnóstico institucional da área do estudo, apreendido pela pesquisadora como subsídio necessário e fundamental para o conhecimento da realidade com a qual trabalhamos.

Este estudo foi realizado na creche Centro de Acompanhamento do Desenvolvimento Infantil (CADI) 34 Jd Elisa Maria. Essa creche é pública e está sob a administração direta da Secretaria de Estado da Administração e Desenvolvimento Social de São Paulo.

Está situada a Rua Rômulo Naldi, 137, no bairro Jd Elisa Maria, na zona norte da cidade de São Paulo. Geograficamente está inserida no Conjunto Habitacional de Parada de Taipas.

Essa instituição iniciou suas atividades em primeiro de setembro de mil novecentos e noventa e dois.

A creche tem capacidade para atender a 120 crianças, na faixa etária dos três meses ao seis anos, em período integral. O funcionamento ocorre das sete horas da manhã às dezoito horas.

A direção da instituição está a cargo de uma assistente social e a supervisão técnica é realizada por uma psicóloga.

A creche está organizada em setores. O setor de recreação e sociabilização, interesse desse estudo é composto pelas recreacionistas e pelas ADI. O setor administrativo tem sob sua responsabilidade a lavanderia, composto pelas auxiliares de lavanderia; a cozinha e lactário, composto pelas oficiais de manutenção, lactaristas e auxiliares de cozinha; a limpeza e manutenção, composto pelas auxiliares de serviço geral. 
Esses setores desenvolvem ações especificas, entretanto, existe uma articulação entre eles, mediada pela diretora e pela supervisora, com o intuito de possibilitar a troca de informações e atualizar assuntos pertinentes à creche.

O quadro de pessoal da creche está constituido por trinta e quatro funcionários.

Todos são funcionários públicos concursados. A diretora, a supervisora e a chefe administrativa respondem por cargos comissionados.

A carga horária de trabalho de seis horas é cumprida pelos funcionários, os quais estão distribuidos em dois turnos, o da manhã e o da tarde.

Esses funcionários ao ingressarem, passaram por um treinamento inicial promovido por uma equipe formada por uma assistente social, uma psicóloga, uma pedagoga e uma fonoaudióloga, autora da presente pesquisa.

O prédio da instituição foi construido no centro de um grande terreno. Há um considerável espaço físico gramado em tomo da creche. Área esta utilizada para o lazer e descanso dos funcionários, assim como para as atividades com as crianças. Existe um playground constituido por um gira-gira e um escorregador. As funcionárias da creche, residentes próximas à creche, informaram que a área, agora ocupada pela instituição, foi por alguns anos, a única área de lazer da comunidade. Ali aconteciam os campeonatos de futebol masculino e feminino da região.

Vinte e oito cômodos constituem as dependências internas da creche, a seguir citados: administração, direção, supervisão técnica, enfermagem, almoxarifado, planejamento, audiovisual, refeitório, cozinha, lactário, despensa, lavanderia, vestiário masculino, vestiário feminino, biblioteca, brinquedoteca, berçário I, berçário II, mini grupo, maternal I, maternal II, dois trocadores infantis e cinco banheiros infantis. 
A creche apresenta boas condições de iluminação, arejamento, funcionalidade e satisfatória situação de conservação e higiene.

Nos trocadores e banheiros, as peças sanitárias estão adequadas ao tamanho das crianças. Os banheiros estão dentro das salas das crianças e apresentam dois chuveiros e dois boxes sanitários, o feminino e o masculino para a higiene dos pequenos.

Todas as salas onde as crianças permanecem possuem grandes armários, onde são acomodados os utensilios (lençóis, travesseiros, cobertores, toalhas, objetos de uso pessoal, etc) pertencentes ao grupo.

Há estímulos visuais (cartazes, móbiles, pinturas com motivos infantis, produções das próprias crianças) afixados em todos os cômodos da creche. 
Planta baixa do CADI 34 Jd Elisa Maria:

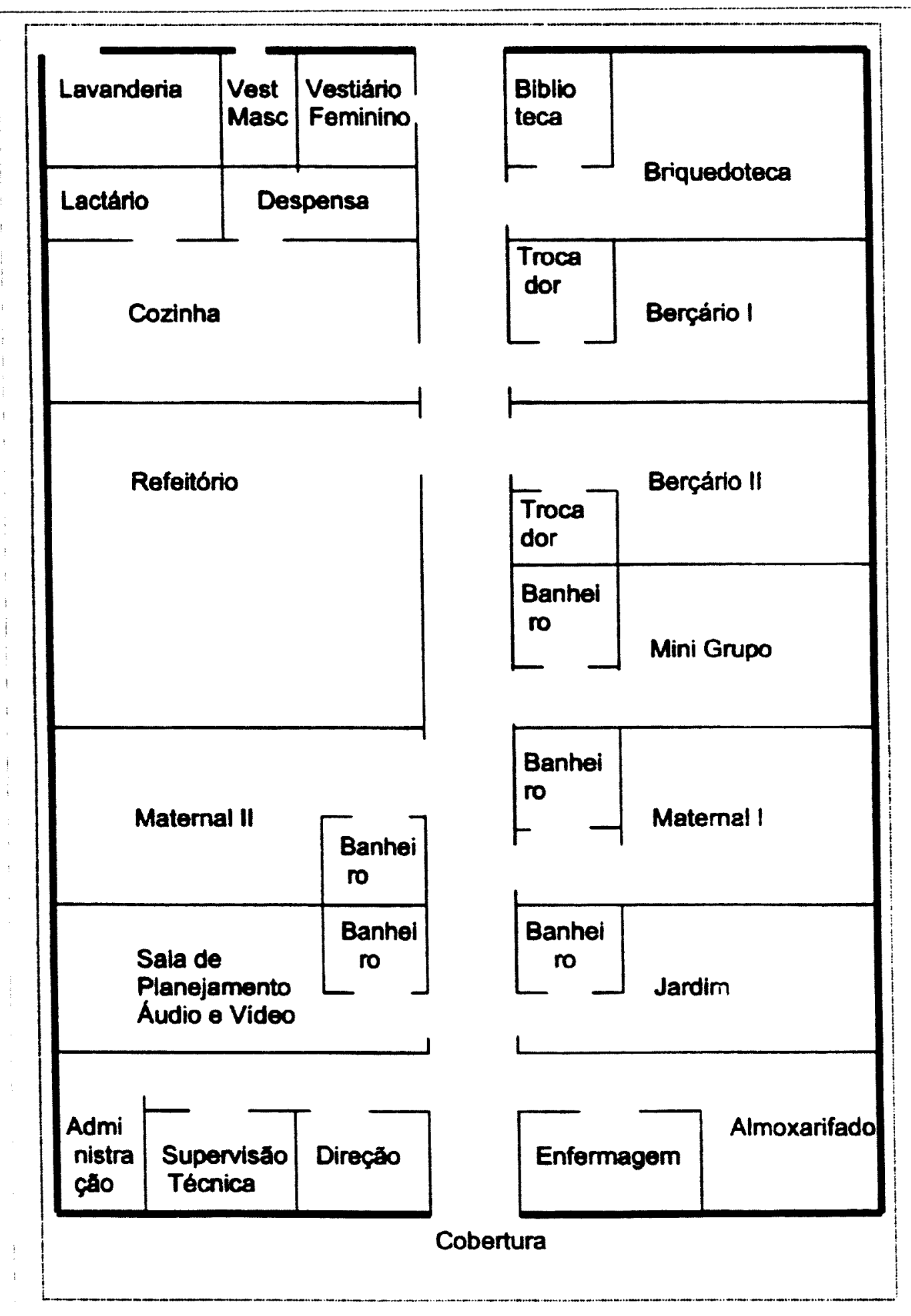


A sala da brinquedoteca dispõe de grande oferta de materiais psicopedagógicos diversificados e de brinquedos para a manipulação das crianças. Um considerável acervo de literatura infantil e infanto-juvenil faz parte da biblioteca da creche. A aquisição desses materiais é realizada por meio de doações e compras com verbas próprias da creche.

Os critérios para o ingresso das crianças na creche compreendem: que as famílias possuam residência fixa na área de abrangência da instituição, isto é, no bairro Jd Elisa Maria; que sejam observadas as condiçōes sócio-econômicas e de saúde da familia e das crianças e que os responsáveis pelas familias exerçam algum trabalho.

As familias selecionadas passam por entrevistas iniciais, realizadas pela assistente social e pela psicóloga. Este contato tem, segundo a diretora, a finalidade de conhecer o contexto familiar das crianças e suas condições gerais de desenvolvimento. Cada criança tem o seu prontuário, no qual estão registradas todas as informações sobre o acompanhamento médico-nutricional e psicopedagógico realizado durante a sua permanência na instituição.

Quanto à alimentação, existe um cardápio que é preparado pelas funcionárias da cozinha, supervisionado pela direção. Existe a preocupação de oferecer às crianças uma alimentação variada e equilibrada, composta por cames, cereais, verduras, legumes, frutas e laticinios. Estes alimentos são fornecidos pelo Estado e os demais, doces, iogurtes, latarias, etc, comprados pela direção através de verba própria.

A distribuição das crianças em grupos de atendimento atende aos critérios de idade cronológica associada às condições gerais de desenvolvimento e observação da aquisição da autonomia para andar e alimentar-se.

Na ocasião da realização da pesquisa, 96 crianças estavam matriculadas, assim distribuidas: 
Berçário I ( 3 meses a 1 ano): 10 crianças. Quatro ADI são responsáveis por essa turma, duas pela manhã e duas pela tarde.

Berçário II (1 ano e 1 més a 2 anos): 18 crianças. Duas ADI são responsáveis por essa turma. Uma pela manhã e outra pela tarde.

Mini grupo (2 anos e 1 mes a 3 anos): 18 crianças. Duas ADI são responsáveis por essa turma. Uma pela manhã e outra pela tarde.

Maternal I ( 3 anos e 1 mês a 4 anos): 24 crianças. Duas ADI são responsáveis por essa turma. Uma pela manhã e outra pela tarde.

Matemal II (4 anos e 1 més a 5 anos e 6 meses): 26 crianças. Duas ADI são responsáveis por essa turma. Uma pela manhã e outra pela tarde.

Grande parte das crianças matriculada nessa creche provém de familias com precárias condições sócio-econômicas, residentes nas imediações da creche em moradias como favelas e casas na modalidade COHAB.

A creche apresenta a seguinte rotina:

$\begin{array}{ll}7 \mathrm{~h} \text { às } 8 \mathrm{~h} & \text { entrada das crianças/higiene/roda de conversa } \\ 7 \mathrm{~h} \text { às } 8 \mathrm{~h} 15 \mathrm{~m} & \text { primeira alimentação do B I } \\ 8 \mathrm{~h} \text { às } 8 \mathrm{~h} 30 \mathrm{~m} & \text { desjejum demais grupos } \\ 8 \mathrm{~h} 30 \mathrm{~m} \text { às } 10 \mathrm{~h} & \text { atividades psicopedagógicas/recreação/banho } \\ & \text { de sol } \\ 9 \mathrm{~h} 30 & \text { hidratação hidrica } \\ 10 \mathrm{~h} & \text { higiene }\end{array}$




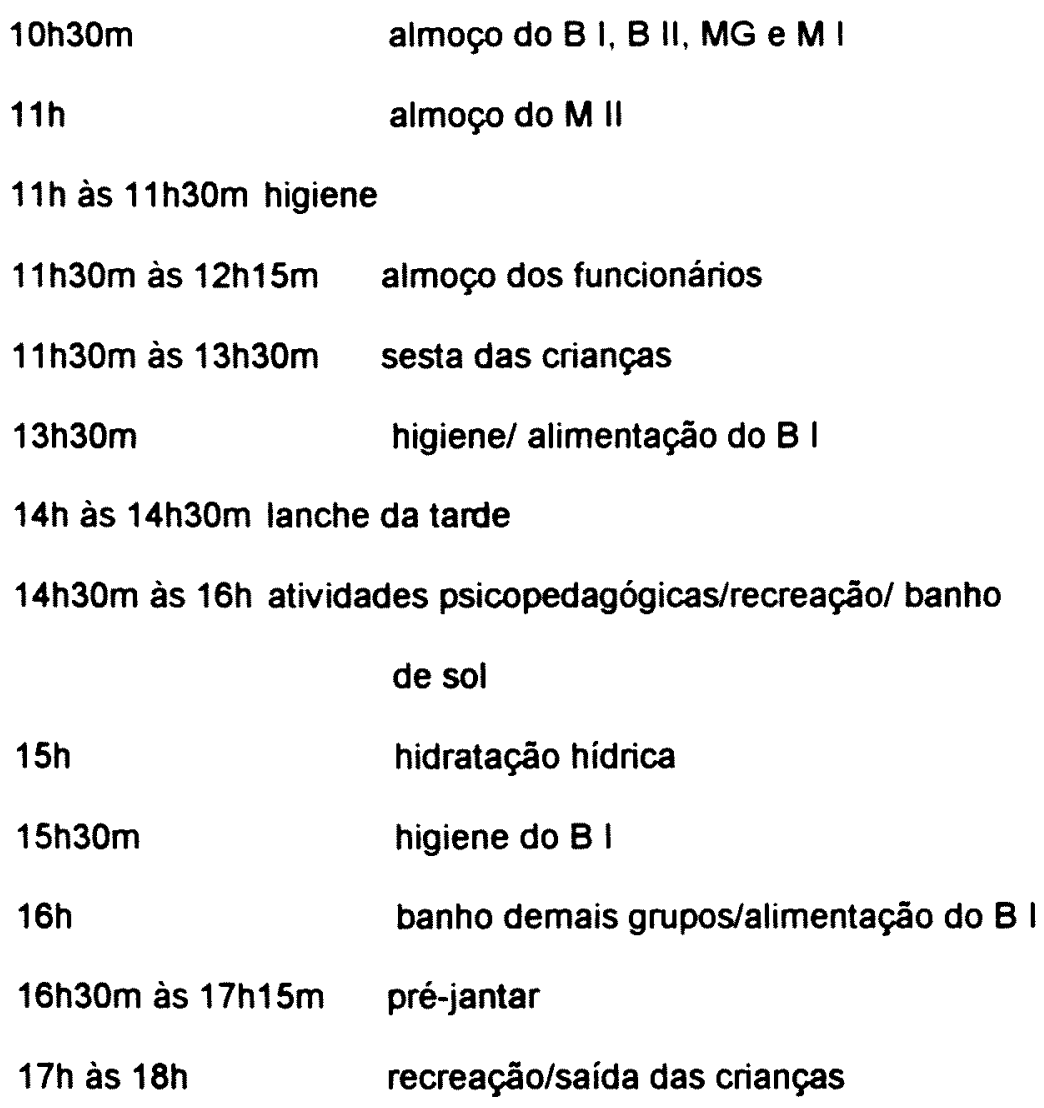

A prática educativa desenvolvida nessa instituição tem seu embasamento na teoria sócio-interacionista de desenvolvimento infantil.

A equipe de $A D I$ segue a proposta psicopedagógica elaborada pela pedagoga da creche. Esta profissional, desde o início do ano de 1998, não faz mais parte do quadro de funcionários porque se transferiu para o interior do Estado.

O planejamento psicopedagógico anual dessa creche pretende que "a criança adquira autonomia, seja observadora, participativa, questionadora e crítica, que possa exercitar a sua imaginaçăo encontrando na creche espaço para se divertir e também respostas as suas necessidades num ambiente estimulador que favoreça o seu desenvolvimento global' (PROPOSTA PSICOPEDAGÓGICA DO CADI 34, 1998)". 
Para tanto, deve este projeto psicopedagógico, "oferecer oportunidades lúdicas, afetivas, psicomotoras, de linguagem, perceptivas, cognitivas e sociais para as crianças vivenciarem e experimentarem" (PROPOSTA PSICOPEDAGÓGICA DO CADI 34, 1998).

As atividades psicopedagógicas são discutidas em reuniōes e elaboradas em conjunto com a supervisora e as ADI.

As atividades acontecem nas próprias salas das crianças, na sala de áudio e video, na brinquedoteca, no refeitório e na área externa da creche.

A interação creche-familia realiza-se nos momentos de triagem diária das crianças na entrada da creche. Nesses momentos, os pais ou responsáveis tem o contato direto com a auxiliar de enfermagem e as ADI. Existem, ainda, as reuniōes gerais de pais e as reuniões por grupos de ADI com a participação da diretora e da supervisora.

A participação da comunidade é também incentivada por meio da organização de palestras, de exposições de trabalhos realizados pelas próprias crianças, de quermesses e de bazares. 
Anexo 2: A Proposta Psicopedagógica do CADI 34 Id Elisa Maria 


\section{PROGRAMACÃO ANUAL - PROPOSTA PSICOPEDAGÓGICA}

Nossa proposta se concretizará baseada na Literatura Infantil, de onde depreenderemos temas com os quais trabalharemos interdisciplinarmente.

Cremos que os livros infantis despertam a curiosidade infantil, confrontando o seu próprio mundo com os personagens literários e desse conflito 0 desafio de encontrar um referencial.

Pretendemos que a criança seja autônoma, observadora, participativa, questionadora e critica. Aspiramos a que a criança possa exercitar a sua imaginação encontrando espaço para se divertir e também respostas as suas necessidades num ambiente estimulador que favoreça o seu desenvolvimento global.

\section{OBJETIVO}

Oferecer oportunidades lúdicas, afetivas, psicomotoras, de linguagem oral, perceptivas, cognitivas e sociais, que favoreçam a autoconstrução da vida da criança.

Para alcançarmos este objetivo, abordaremos temas próximos às crianças, baseando-nos em suas próprias experiências e desafiando-as diante do que não conhecem, provocando desta maneira, o despertar das aprendizagens informais e formais.

\section{ATIVIDADES DESAFIADORAS}

Motivar o exercicio da leitura.

Dialogar com as crianças.

Vivenciar experièncias próprias, do outro e do meio visando gerar conflitos entre o que elas já sabem e o que devem apreender.

\section{DIAGNÓSTICOS E CRITERIOS DE AVALIACÃO}

A avaliação será feita através de observações diárias e continuas das crianças.

Às turmas do mini grupo, maternal e jardim, no final de cada semestre, será feita uma avaliação descritiva, abordando os aspectos lúdicos, afetivos, de linguagem oral, psicomotores, perceptuais, cognitivos e sociais.

\section{CADI 34 JD ELISA MARIA - DARSP NORTE}

Às turmas do berçário I e berçário II, tendo em vista o rápido desenvolvimento nesta faixa etária, a avaliação será bimestral, avaliando-se descritivamente 0 desenvolvimento global da criança.

A recreacionista responsável pela sala fará um caderno de registro, informando os progressos e dificuldades percebidos na sua turma, que serão discutidos nas reuniōes semanais.

Bimestralmente realizaremos reuniões de pais, por turmas, com a intenção de apresentar o desenvolvimento do planejamento e sensibilizá-los da importancia da continuidade das açōes educativas em seus lares. 
A avaliação do CADI 34 será diária, contínua, individual e coletiva!

\section{PROJETO DE ACCÃO}

Através de grupos de estudos, realizados durante o mês, faremos o desenvolvimento das atividades, visando a troca de experiências e o embasamento teórico, enfim, o enriquecimento do trabalho coletivo para o melhor desenvolvimento de nossas crianças.

\section{CRONOGRAMA MENSAL}

- 1" semana - reunião com ADI, recreacionistas e equipe técnica. Uma turma de crianças por dia.

- $2^{a}$ semana - planejamento das atividades a serem dadas no mês pelas recreacionistas.

- $3^{a}$ semana - preparação das atividades a serem dadas no mês.

- $4^{a}$ semana - reflexão sobre o trabalho desenvolvido nas salas, auto-avaliação, leitura de apostilas, textos e documentos fornecidos pela equipe técnica.

\section{RECURSOS}

Humanos: equipe técnica, recreacionistas e ADI.

Materiais: videos, livros, textos, apostilas e materiais psicopedagógicos.

\section{PERIODOS}

Toda a $2^{a}$ semana do mês realizaremos a Semana Pedagógica, unindo todas as recreacionistas, no seguinte horário - das $10 \mathrm{~h}$ às $13 \mathrm{~h}$.

No restante do mês, os contatos diários e o acompanhamento do desenvolvimento do planejamento, o horário fica assim estabelecido:

\# periodo da manhã: $7 \mathrm{~h}$ às $9 \mathrm{~h}$ e das $12 \mathrm{~h}$ às $13 \mathrm{~h}$;

\# período da tarde: $12 \mathrm{~h}$ às $13 \mathrm{~h}$.

\section{EVENTOS DENTRO E FORA DO CADI 34}

A programação sócio-cultural consiste em excursão ou visitas bimestrais com as crianças, provavelmente nos locais como teatro, Parque Vila Lobos, SESC Itaquera/Interlagos/Pompéia, Jardim Zoológico, Circo Escola da Freguesia do Ó, Bibliotecas Infantis e Horto Florestal.

Das datas comemorativas, trabalharemos todas previstas no calendário, sendo que serão abertas às famílias e à comunidade:

O dia das Mães, a Festa Junina e a Formatura. 
CADI 34 - JARDIM ELISA MARIA

Programacão Anual para a Sala do Maternal II ( 4 anos e 1 mês a 5 anos e 6 meses)

I. Conteúdos Gerais

Conhecimentos dos conteúdos anteriores e mais:

- Função do pessoal da creche e familiares,

- Função das partes do corpo (inclusive dos sentidos)

- Meios de transporte,

- Fenômenos da natureza;

- Vestuário adequado;

- Animais úteis;

- Alimentação.

II. Áreas Trabalhadas

Área de Comunicação e Expressão

Atividades de Expressão Oral

Objetivos Especificos

-Identificar e associar o objeto à sua função;

- Descrever objetos, através de sua função ou características;

- Agrupar os objetos descrito, segundo suas funçōes ou caracteristicas;

- Compreender ordens verbais que envolvam objetos nomeados;

-Expor idéias oralmente, ordenando palavras (sujeito, predicado e complementos);

- Estabelecer diálogos simples: pergunta e resposta;

Conteúdo

- Memorizar e verbalizar novas palavras, utilizando-as em outras situações.

Corpo Humano:

Animais:

- Os sentidos (funções), rosto, sombrancelhas, cilios.

Objetos:

Cabrito, carneiro, abelha, tartaruga, aranha, porco, boi, vaca, cavalo e pato.

- Objetos de cozinha, de quarto, de banheiro, de quintal, de higiene pessoal, móveis e utensilios.

Vestuário:

Locais:

-Adequação das roupas (calor, frio e chuva).

- Ponto de ônibus, estação de trem, aeroporto, padaria, farmácia, supermercado, açougue, loja, igreja, praça, refeitório, prédio.

Meios de transporte:

- Carro, ônibus, trem, avião, barco, caminhão, bicicleta.

Elementos da Natureza:

- Ar, trovão, relâmpago, rio, estrela, lua.

Noção Espacial e Temporal:

- Perto e longe, dia, noite.

Brinquedos e Brincadeiras: Açōes:

- Amarelinha, bicicleta, pegador, tico-tico, encaixe, bate-estaca.

- Ajudar, conversar, ir, buscar, levar, gritar, cantar, assobiar, mastigar, engolir, olhar, ouvir, cheirar, cair, trepar.

Nomes de Pessoas que Tem Alguma Funçăo no Parque:

- Serviçal, cozinheira, diretora, educadora, enfermeira, professor (recreacionista).

Qualidade, Sensação e Emoção:

- Feio, bonito, medo, susto, frio, salgado, doce, cansado, quente, barulho

Sugestöes de Estratégia

Exercicios de Identificação e Verbalização

- Hora da novidade; 
- Roda de estória;

- Hora da conversa: toda segunda-feira, o professor deve no primeiro contato com a criança, conversar sobre o que aconteceu no fim de semana, tentando fazer com que a criança não só se lembre, mas verbalize o que aconteceu;

- Leitura pelo professor de livros infantis;

- Apresentar uma série de figuras (ou objetos) para a classe. Uma criança de cada vez, pega a figura (ou objeto), pedido pelo professor ou por outra criança;

- Exercícios tais como: "Vamos vestir a boneca.";

- As crianças revezam para encontrar uma roupa pedida pelo professor ou por outra criança e vestem a boneca;

Exemplo:

- Objetos são colocados numa "caixa surpresa" pelo professor, ou por outra criança.

uma cama, cadeira são colocados diante da classe, uma criança de cada vez demonstra com uma boneca, como usar a mobilia. Depois o professor diz: "Mostre-me onde se dorme. Sente-se.";

- Pode-se explorar todas as características e funções dos objetos apresentados, através da hora da novidade e hora da conversa;

- Adivinhações, como por exemplo, dizer à criança: "O que é, o que é? Chora quando está com fome e mama na mamadeira?". A criança deve responder: "É o bebê.". "É redonda, colorida e pula pra valer?". A criança deve responder: "É a bola.";

- Figuras e brinquedos são colocados no flanelógrafo, como por exemplo, os que choram, os que andam, etc; do corpo:

- A figura de uma criança é colocada frente à classe. As crianças apontam as partes

"Como é que ela vê?", etc;

- Diversos objetos familiares são colocados num cesto, o professor pede a criança: "Procure o objeto com que você escova os dentes.". A criança coloca a mão dentro do cesto e sente o objeto, pega-o e dá para o professor dizendo o que é.

Obedecer Ordens

- Pode-se dar ordens, as mais diversas possiveis. Exemplo: O professor diz: "Vamos fingir que somos macacos. Primeiro vamos subir a escada, depois pegar no galho da árvore e balançar.". As crianças imitam os passos necessários;

- Discute-se a seqüência dos atos ao se levantar da cama, ir ao banheiro, escovar os dentes, tomar café e depois brincar. As crianças deverão fazer os gestos;

- Dar ordens simples, como por exemplo: "Guarde este caderno ao armário.", etc;

- Exercicios onde as crianças brincam de seguir ordens.

\section{Formaçåo de Frases}

- A ADI conta uma estória simples. As crianças repetem as oraçōes e dramatizam a estória em seqüência;

- As crianças são encorajadas a dizer orações de rotina na sala como: "É minha vez!", "Eu já acabei.", "Quero ir ao banheiro.", etc;

- Explorar gravuras com cenas simples para que as crianças formem frases;

- Jogos de imaginação, através de estórias e cartazes. Exemplo: conta-se uma estória e pede-se à criança que imagine o seu final.

Responder Perguntas

- Fazer perguntas como:

" Para que serve o fogão?

* Para que servem as casas?

* O que você faz quando esta com sede?;

- Perguntas simples e objetivas para as crianças. Memorizaçăo e

Verbalização

- Colocar um cavalo, um ônibus e uma vassoura na frente das crianças. Chamar a atenção de cada objeto e pedir que os nomeie. Dizer então: "Agora fechem os olhos para não verem o que vou fazer.". Tomar um objeto e dizer: "Olhe agora e digam o que foi que escondi!".

Classificação

- São colocados diversos objetos sobre a mesa: pasta de dente, sabonete, escova, sapato, etc. A ADI pede: "Procure o que combina com a pasta de dente."; 
- Dar revistas para as crianças e pedir para que elas recortem:

* Coisas para comer,

* Coisas que andam, etc.

Desenvolvimento Motor

Objetivos Especificos

- Identificar, reconhecer e nomear todas as partes do corpo;

- Associar os órgãos de sentido à sua função;

- Comparar as posições dos objetos no espaço para estabelecer relações entre eles;

- Localizar-se no espaço, tomando o próprio corpo como referencia;

Conteúdo

- Reproduzir movimentos globais e parciais e criar movimentos globais e parciais.

Orientaçăo Espacial

- Ter conhecimento de perto e longe;

- Saber localizar-se dentro do ambiente, com olhos abertos e depois com olhos fechados, sabendo onde estão os elementos, exemplo: a porta, a janela, etc.

Esquema Corporal

- Saber localizar todas as partes do corpo;

- Saber para que servem todos os órgãos dos sentidos. Equilíbrio

- Pular em um pé só;

- Andar na linha, na ponta dos pés;

- Andar no calcanhar.

Coordenação Geral

- Subir e descer escadas, alternando os pés;

- Embocar uma bola, não muito grande, em um arco formado pelos braços, a pequena distância.

Coordena elo Fina objeto;

- Reproduzir formas de objetos com o dedo, tendo, antes contornado o próprio

- Enfiar contas pequenas. Sugestão de Estratégia

- Nomear objetos que estão do lado, na frente, atrás, em cima, em baixo, etc:

- De olhos fechados apontar onde estão as coisas, tendo antes feito de olhos abertos, exemplo:

porta, mesa, etc:

- Jogos com ordens para dirigir-se a locais pré-combinados, exemplo: uma palma: corre para a janela, duas palmas: corre para a porta, etc;

- Uma criança anda pela sala e as outras nomeiam os lugares por onde ela passa

- Pedir à criança que pegue a bola que está longe, a bola que está perto da janela, a que está ao lado do amiguinho, etc; ordens):

- Andar e correr pela sala inteira, pela saia dividida ao meio, em quatro... (seguindo canos,

- Idem o exercício anterior, porém com as crianças andando imitando ônibus, trens,

- Segurar a mão do colega que está perto, apontar o colega que está longe;

etc;

- Andar e engatinhar seguindo linhas no chão, linhas curvas, quebradas, sinuosas,

- Pular em pontinhos marcados no chão;

- Jogo de coelho sai da toca. Esquema Corporal

- Contomar o corpo de uma criança com giz de lousa, pedir que se coloque as partes que estão faltando, exemplo: boca, orelha, olho, etc:

- Levar a criança, de olhos fechados, a apontar onde estão localizadas as panes de seu corpo, exemplo: braço, nariz, etc;

- Em brincadeiras de roda, as crianças se seguram pelas mãos, depois pelos braços, pelos cotovelos, ombros, etc. (seguindo ordens);

- Ficar o mais alto que puder, o mais baixo que puder, o maior que puder, o menor que puder, o mais gordo que puder, etc. 


\section{Sentidos}

- Cheirar coisas com cheiros diferentes, agrupando os iguais; que são;

- Apalpar objetos com formas diferentes, colocadas dentro de um saco, dizendo o

- Apalpar superficies frias e quentes, ásperas e lisas, etc;

- Jogos fáceis de memória visual, exemplo: colocar tres, quatro ou cinco objetos a frente das crianças, pedindo que elas observem bem. Em seguida, sem que elas vejam, retirar um objeto e pedir que as crianças digam qual foi o que saiu, $O$ mesmo pode ser feito mudando a posição dos objetos.

Equilibrio

- Andar na linha (curvas, quebradas, sinuosas, etc.);

- Andar na ponta dos pés, no calcanhar;

- Andar sobre uma linha, carregando um objeto na mão:

- Andar equilibrando coisas em uma colher, por exemplo: tomate, batata, etc;

- Andar carregando uma caneca quase cheia sem derramar:

- Andar para trás;

- Carregar objetos grandes, em dois, exemplo: uma caixa de brinquedos, etc;

- Atravessar a sala pulando em um pé só;

- Saltar obstáculos.

\section{Coordenação Geral}

- Jogos com ordens para que a criança assuma diferentes posições, exemplo: uma palma: ficar em pé, duas palmas: ficar sentado;

- Dramatização: animais, pessoas andando na lama, na chuva, carregando pacotes leves, pesados, etc;

- Dramatizar as tias nas suas funçōes: cozinhando, varrendo, lavando roupa, etc;

- Estórias dramatizadas, exemplo: "Num dia de sol vamos passear. Brincamos bastante, corremos, pulamos, saltamos, etc. De repente escutamos um barulho. Começa a chover. Como esse barulho? O que nós fazemos? Corremos para nos esconder da chuva e ficamos escutando o seu barulho. Como ê esse barulho? Aos poucos a chuva vai passando e nós saimos novamente para brincar. Como está agora o caminho? Há lama - vamos andar na lama. Há poças d'água. Vamos pular as poças e voltar para casa."

- Imitar ônibus. trens, aviōes, etc;

- Exercicios de espelho com movimentos que exigem maior atenção: abrir e fechar os olhos, olhar para um lado e para o outro, mexer os dedos, abrir e fechar a boca, etc;

- Lançar coisas à distância em um alvo. Exemplo: embocar uma bola dentro e fora de um arco formado pelos braços;

- Jogos de corda;

- Exercicios com saquinhos de areia. Exemplo: jogar o saquinho para o alto e pegar, jogar o saquinho de uma mão para outra;

- Jogos com bola;

- Jogar bola de duas crianças ou em grupinhos maiores;

- Jogar bola de dois a dois, batendo a bola uma vez no chão;

- Jogar bola na parede e pegar, etc;

- Bater em um saco de pancadas;

- Dar cambalhotas com o auxílio do professor;

- Pular amarelinha, caracol, barra manteiga, etc

- Jogo de estátua, jogo de passos, pegador, etc.

\section{Relaxamento}

- Colocar um livro sobre o peito e observar o movimento do livro;

- Ir franzindo a testa, até fazer uma cara bem brava e depois lentamente, ir voltando ao normal;

- Imitações de plantas, desde a sementinha, até a árvore, utilizando o como.

\section{Coordenação Fina}

- Jogos de encaixe, de empilhar, de enfiar, de construção, quebra-cabeça, etc. (usar material pedagógico e também canudos, tubos, caixas de vários tamanhos, etc);

- Desenho livre com lápis de cera, giz, vela, lápis de cor (ir reduzindo o tamanho do papel); 
etc;

- Desenho de sons ouvidos, exemplo: do barulho do ônibus, do avião, do passarinho,

- Colagens:

"com recortes a dedo e a tesoura,

- com papéis médios e pequenos cortados,

* com objetos pequenos (grãos, palitos, etc).

* com bolinhas de papel enroladas pelas crianças,

* com espaços delimitados;

- Barro;

- Sensibilização, de olhos fechados;

- Fazer cobrinhas e bolinhas com a mão;

- Trabalhar livremente;

- Pintura com guache: com pincel, dedo, com conta-gotas, etc;

- Atelier livre, utilizando sucatas grandes e pequenas;

- Separar grãos diferentes;

- Reproduzir, com o dedo, formas de objetos esquemáticos e simples, sendo antes contomado, com o dedo, o próprio objeto;

- Folhear revistas;

- Enfiar contas grandes;

- Enfiar contas pequenas, fazendo colares;

- Alinhavo, sem desenho, em papelão;

- Exercícios de xadrez, onde a criança faz com o giz ou lápis de cera, movimentos de cima para baixo e da esquerda para a direita, em dois planos: horizontal e vertical;

- Carimbo com as mãos e com os dedos, em seqüência (começando pelo polegar até o mindinho e vice-versa);

- Copiar modelos feitos com blocos.

\section{Atividades de Iniciação Musical}

Objetivos Específicos

- Associar movimentos corporais a ritmos diferentes;

- Reproduzir ritmos simples;

- Reconhecer e identificar sons realizando contrastes entre fraco e forte;

- Reconhecer e identificar sons realizando contrastes entre depressa e devagar;

- Memorizar pequenas cançōes. Conteúdo

- Canto;

- Ritmo;

- Forte e fraco - intensidade;

- Depressa e devagar - andamento;

- Pesquisa de som com a própria voz;

- Pesquisa de som com materiais ou objetos:

- Pesquisa de som com instrumentos musicais;

- Pesquisa de som com o próprio corpo; Ritmo

- Conhecer e reconhecer sons. Sugestões de Estratégia

- Fazer uma roda com as crianças. Elas devem ficar no mesmo lugar, sem se dar as mãos. Cantar uma música já conhecida pelas crianças, e acompanhar o seu ritmo batendo os pés no chão, ou batendo as mãos no joelho, etc;

- Formar uma roda com as crianças. Elas devem ficar no lugar, sem se dar as mãos. Cantar uma música e acompanhar o seu ritmo, batendo com as mãos. Uma vez palmas, outra vez nos joelhos, outra batida nos joelhos, uma de palmas, e assim por diante, até o fim da música;

- Pode-se tirar ritmos diferentes das palavras que falamos normalmente. As crianças ficam sentadas numa roda, de criança em criança pede-se: "Diga o seu nome.", repete-se várias vezes seguidas o nome da criança, ao mesmo tempo acompanhamos o ritmo do nome, batendo palmas ou com um instrumento;

- Também pode-se tirar ritmos novos e diferentes de frases emitidas. Por exemplo: Pedir para as crianças darem uma olhada no que é que elas estão vendo na sala.

Forte e Fraco - Intensidade 
- O forte deve ser forte mesmo e o fraco deve ser fraco mesmo;

- Cantar uma música que elas já conhecem. Primeiro cantar a música da maneira que estio acostumadas. Depois cantar de novo a música, só que desta vez bem fraco e, em seguida, bem forte;

- Sentar as crianças numa roda. Dar um instrumento. Primeiro cantar normalmente, depois cantar e tocar forte e, em seguida, tocar e cantar fraco;

- Combinar com as crianças que "quando o tamborete calho tocar, vamos dar um pulo bem forte, quando o chocalho tocar, vamos fazer movimento só com as mãos, bem de leve.

Depressa e Devagar - Andamento

- Primeiro, cantar normalmente e a roda também gira no andamento normal da música. Depois cantar bem depressa e a roda também depressa e, em seguida, bem devagar e a roda também bem devagar;

- Variações para acompanhar o ritmo - bater palmas, bater pés no chão, etc. Pesquisa de Som

É a atividade que leva a criança a descobrir sons novos e diferentes, por exemplo: a voz, o ambiente, objetos, materiais e instrumentos e o próprio corpo.

Pesquisa de Som com a Própria Voz

- Dramatizar estórias, as crianças vão imitando os sons, por exemplo: o trem, o cavalo, etc, além de imitar o som, poderio ser imitados os gestos;

- Deve-se fazer estórias curtas e simples, mas que dêem margem a muita imaginação e criatividade da criança, quanto ao som e movimento;

- Pode-se ainda basear a estória em gravuras, objetos, músicas que elas já conhecem, profissōes, etc;

\section{Pesquiso de Som no Ambiente} exemplo:

- Pode-se encontrar muitos sons diferentes na sala ou noutro ambiente, como por

" bater as mãos no chão

- bater as mãos na mesa

* bater as mãos na porta

* bater as mios na parede

* bater as unhas no vidro da janela

* bater com as unhas no chão, na porta, na parede

* empurrar as cadeiras

* abrir e fechar as portas, janelas, etc;

Como se pode levar as crianças a descobrir estes sons?

- Deve pedir para que as crianças prestem atenção, como o professor faz, para depois fazer igual, e também observem as diferenças de sons;

- Levar as crianças a inventar estórias, com os sons que elas já conhecem. Exemplo: bater os pés no chão, imitar um homem grande e pesado.

\section{Pesquisa de Som com Materiais e/ou Objetos}

Sugestões

Papel Jomal:

- Rasgar o papel: sempre é bom rasgar bem perto do ouvido delas, para realmente chamar a atenção sobre o som;

- Rasgar o papel no chão;

- Amassar o papel: também próximo ao ouvido;

- Bater com a palma da mão no papel;

- Segurar a folha nas duas mãos, bater puxando, sem deixar rasgar, etc.

Papel Celofane:

- As crianças sentadas no chão, cada uma com um pedaço suficiente de papel celofane, para poder explorá-lo ao máximo. Proceder como nas sugestões anteriores;

- Outros materiais que pode-se explorar: blocos de madeira, latas, tampas, tampinhas de garrafas, etc.

\section{Pesquisa de Som com instrumento}

São instrumentos simples e fáceis de fazer, como por exemplo: 
- Chocalhos de potinhos de iogurte;

- Chocalhos de lata;

- Chocalhos de tampinhas de garrafas;

- Tamboretes com caixas redondas de queijo "catupiri";

- Tamborim (ou pandeiro) com caixas de queijo "catupiri";

- Cuíca com lata de leite grande;

- Pauzinhos de madeira;

- Pratinhos com tampinhas de garrafas;

- Pratos com tampa de lata;

- Coco;

- Tacos de madeira;

- Reco-reco.

Pesquisa de Som com o Próprio Corpo

Pode-se encontrar muitos sons no nosso próprio corpo, como:

- Nas mãos:

- Nos pés;

- Com a boca;

- Com o nariz:

- Com os pés.

Área de Integração Social

Atividades de Integração Social

Objetivos Especificos

- Identificar pessoas de convivência diária (pais, irmãos, professores, etc.);

- Associar as pessoas às suas funções;

- Discriminar as tarefas executadas pelas pessoas;

- Associar os objetos às suas tarefas executadas;

- Classificar objetos segundo suas funções;

- Ter conhecimento sobre os meios de transportes;

- Desenvolver hábitos de convivência social. Conteúdo

- Nome e função das tias;

Objetos usados nas dependências do Cadi;

Conhecimentos dos materiais usados pelo grupo;

Perceber como os acontecimentos se distribuem dentro de um dia;

Observação da rua (transportes, observação, comparação e necessidade);

Conhecer os nomes e as características dos membros de sua familia.

Sugestōes de Estratégia Nome Funçáo das tias

- Visitar as dependências do Cadi, observando o trabalho dos funcionários responsáveis, nessas visitas, estimular as crianças à perguntarem sobre o trabalho de cada pessoa;

- Desenho ou colagem - as crianças passam para o papel o que viram na visita;

- Entrega de pequenos objetos. Exemplo: Leve esta caixa à tia da cozinha, etc.

Objetos Usados nas Dependéncias do Cadi

- Fazer novas visitas observando e recebendo informações sobre os objetos; funções;

- Hora da novidade - alguns objetos utilizados pelas tias nas suas respectivas

- Recortar de revistas objetos pertencentes a: cozinha, lavanderia, etc.

\section{Conhecimentos dos Materiais Usados pelo Grupo}

- Apresentação do material contando estórias. dizendo à criança para que serve cada um;

- Separar o material junto com as crianças, pelas diferenças e utilidades. Colocá-lo em caixas com símbolos para que as próprias crianças identifique-os.

Perceber como os Acontecimentos se Distribuem Dentro de um Dia

- Elaborar um quadro onde as crianças colocarão antes de cada atividade de rotina: café, almoço, etc;

- Contar estórias com seqüências e em seguida distribuir gravuras referentes a elas, para que coloquem na mesma ordem da estória ouvida. 


\section{Observação da Rua}

- Transportes: observação, comparação e necessidade;

- Pequenos passeios para que as crianças observem mais de perto o movimento da rua, os meios de transporte;

- Desenho, colagem, pintura, modelagem, trabalhos com sucatas;

- Comparar os meios de transporte, observar o tamanho;

- Apresentar gravuras e pedir que as crianças recortem ao redor das gravuras que representam os meios de transporte;

- Dramatização relativa aos meios de transporte.

Conhecer os Nomes e as Caracteristicas dos Membros da Familia

- Características físicas;

- Características de vestuário;

- Características de funções.

Atividades da Vida Prática

Objetivos Especificos

- Demonstrar iniciativa e independência em relação ao uso do vestuário;

- Organizar-se em relação aos hábitos de higiene pessoal e do ambiente;

- Transmitir enunciados orais. Conteúdo

- Vestir-se e calçar-se sozinho (sem dar laço);

- Pentear o cabelo;

- Varrer e tirar o pó da sala;

- Dar recados.

Sugestões de Estratégia

A ADI deverá aproveitar todas as oportunidades que surgirem para o treino dos seguintes comportamentos na criança:

- Colocar a chave na fechadura (sem trancar);

- Escovar bem os dentes;

- Pôr a roupa e o sapato (sem dar laços);

- Pentear os cabelos;

- Varrer locais variados e tirar o pó da sala;

- Arrumar a sala;

- Lavar as mãos;

- Colocar a roupa na sacola;

- Abotoar a roupa;

- Começar a se lavar sozinho:

- Dar recados;

- Recolher colchões;

- Retirar o lixo;

- Enxugar os pratos e canecas (inquebráveis).

Área de Iniciação à Ciência

Atividades de Matemática

Objetivos Específicos

Trabalho com Material Concreto

Levar à criança a

- Conhecer os materiais com os quais ela trabalha;

- Classificar gradativamente os materiais por seus atributos: cor, forma, etc;

- Comparar objetos pela cor, forma (sem necessidade de verbalização);

- Seriar objetos de acordo com o modelo dado;

- Reforçar alguns conceitos já dominados e desenvolver outros;

- Em cima, em baixo

- Cheio, vazio;

- Grande, pequeno;

- Diferente, igual;

- Maior que, menor que;

- Dar Noções Informais de Agrupamentos. Trabalhos com Blocos Lógicos

Levar a criança a

- Conhecer as três cores dos blocos lógicos e reconhecê-las nos objetos que as 
rodeiam, verbalizando-as

- Conhecer os triângulo, o círculo e o quadrado, reconhecendo-os nos objetos que as cercam (sem necessidade de verbalização correta);

- Classificar os blocos lógicos nos seus atributos: cor e forma;

- Seriar os blocos lógicos à vista de modelos;

- Desenvolver os conceitos abaixo, reforçando também, os já dominados:

- longe, peno

* em frente, atrás

* de um lado, do outro

- Continuar a noção informal de agrupamento. Conteúdo

Que a criança: e formas;

Retina objetos diferentes, de acordo com seus atributos: espécies diferentes, cores

- Use corretamente os conceitos mencionados nos objetivos especificos, verbalizando-os e executando ordens;

- Compare objetos de diferentes tamanhos, usando expressões como: é maior que, é menor que, é diferente de, etc;

- Identifique, verbalizando, objetos de cores diferentes (vermelho, azul, amarelo);

- Copie modelos de amumação de materiais diversos e complete;

- Reconheça o triangulo, o quadrado e o círculo, executando ordens, não tem necessidade de

verbalizar.

Sugestōes de Estratégia

Material Concreto

Exploraçåo

- Colocar Materiais, por exemplo, tampinhas numa caixa. A ADI passará esta caixa para que cada criança pegue quantas ela quiser e brinque livremente;

- Introduzir outro material, da mesma maneira;

- Dar os dois materiais ao mesmo tempo, as caixas devem ter colados no lado de fora: uma tampinha, na caixa das tampinhas, um palito na caixa dos palitos. Ao guardar 0 material, a criança realiza a classificação, guardando cada coisa na sua caixa;

- Os símbolos das caixas devem ser, primeiro um exemplo do próprio objeto, depois, poderá se desenhar os objetos e posteriormente simbolos iniciais abstratos, como por exemplo: o desenho de uma bolinha que represente as tampinhas e de duas bolinhas que represente os palitos, etc;

- Dar colagem livre com os dois materiais já explorados;

- Introduzir outro material (milho, feijäo, etc), seguindo os passos anteriores. Classificaçăo

- Dar dois materiais misturados para as crianças separarem;

- Montar um museu com coisas encontradas, tais como: folhas, pedras, etc. Seriaçâo

- Pedir a criança que arrume o material, tampinha e palitos, por exemplo: uma tampinha, um palito, etc;

- Pedir para que elas arrumem o material de outra maneira.

Correspondência

- Começar com o material concreto, partindo da própria criança, exemplo:

* duas crianças e duas cadeirinhas,

- uma criança e uma cadeirinha.

Blocos Lógicos

- Durante mais ou menos três ou quatro semanas deixarem as crianças manipularem livremente.

\section{Separação por Cores}

- A ADI pega um bloco vermelho e chama a atenção da criança para esta cor;

- Fazer um contorno no olho e colocar dentro um cartão com mancha vermelha.

Pedir a criança que coloque dentro do contomo, todos os blocos pintados de vermelho;

- Formar pares de blocos vermelho;

- Formar uma coluna que seja comprida e vermelha;

- Formar uma torre vermelha;

- Fazer pesquisas de coisas vermelhas, na própria sala, no Cadi, etc; 
- Trazer para o Cadi coisas vermelhas; atributos:

- Distribuir todos os blocos entre as crianças, e ir pedindo as peças por seus

- Atividades paralelas;

- Artes: em pintura, desenho e colagem, usar muita cor vermelha;

- Expressão oral: chamar a atenção sobre os elementos das gravuras que sejam vermelhos;

- Passeios;

- Chamar atenção sobre coisas, canos, casas, etc.

Observação: Seguindo estes mesmos passos, serão dadas as cores azul e amarela. Jogos de Reconhecimento das Três Cores

- Fazer três contomos no chão. Em cada um é colocado um cartão com uma mancha vermelha, azul e amarela. As crianças deveräo colocar todos os blocos, cada um na sua respectiva casa;

- Dominó com as três cores. A ADI coloca sempre a primeira peça e as crianças deverão colocar as seguintes;

- Jogo da peça escondida, só com três peças, que sejam diferentes só na cor;

- Coloca-se uma mancha de cada cor em cada parede ou canto da sala. Cada criança portará um crachá com uma das três cores, a um sinal do professor, cada criança irá se colocar na parede ou canto de sua cor.

Reprodução

- A ADI constrói alguma coisa com os cartões das três cores e a criança reproduzirá o desenho, na mesma seqüência, com os blocos lógicos;

- Ditado: a ADI mostra um cartāo com uma das três cores e cada criança irá formando um dominó com os blocos;

- Variação - em vez de mostrar o cartão, a ADI só fala a cor.

Jogo Livre

A ordem a ser dada será:

$1^{0}$ - Circulo;

$2^{0}$ - Quadrado;

$3^{0}$ - Triângulo.

- A apresentação das formas dos blocos será feita da seguinte maneira: o professor pega uma peça e trabalha com a criança, na linha da percepção. Assim, por exemplo com o círculo, a criança passará a mão pelo seu contomo, tentará reproduzl-lo no papel, no ar, recortar, rodará a peça, etc. A criança irá trabalhar com todos os círculos dos blocos;

- A introdução do nome das formas se dará depois que a criança tenha descrito a peça com suas próprias palavras. Exemplo: Esta peça é azul e redonda ou é azul e roda. É importante que no inicio não se exija o nome correto da forma em questão, porém, a ADI deve sempre usar a denominação certa e acostumar, assim, a criança com o novo vocabulário.

Joguinhos Aplicados a Três Formas

- Jogo de separação das formas:

* Em espaço delimitado com a apresentação da forma em questão.

* Com a apresentação da forma desenhada em cartão branco,

- Separação da forma pedida, apenas com a palavra;

- Dominó de formas com uma diferença;

- Dominó de formas dom duas diferenças (cor e forma);

- Cópias de formas apresentadas em cartōes, conduzindo a seriação;

- Jogo da peça escondida, apenas seis blocos (dois quadrados grandes amarelos, dois círculos grandes amarelos e dois triângulos grandes amarelos). Pedir para a criança observar todas as peças e depois esconder uma, para que a criança adivinhe qual a peça que está faltando;

- Riscar no chão um gráfico para a criança preencher com as peças; papel;

- Recortar e colar formas já riscadas pelo professor, em contornos já desenhados no

- A ADI poderá dirigir este trabalho usando os conceitos "em cima", "em baixo", "de lado", "dentro de";

- Colocar alguns blocos num saco e pelo tato, a criança deverá reconhecer a forma;. 
- Ditado de formas: a ADI mostra um símbolo e a criança irá formar alguma coisa;

- Pedir para a criança pegar as trés formas e compará-las;

- Colocar uma em cima da outra, dizer as diferenças entre uma e outra.

\section{Atividades de Ciências Naturais}

Objetivos Especificos

- Comparar elementos através dos órgãos dos sentidos;

- Corresponder um a um estes elementos;

- Agrupar elementos pelo cheiro e pelo sabor;

- Observar fenômenos da natureza;

- Relatar oralmente as observações, respondendo a perguntas simples;

- Explorar a terra, observando suas possibilidades enquanto fonte de vida. Conteúdo

- Corpo humano, exemplo: que a criança consiga, frente a diversos elementos, juntar pelo paladar os iguais e diferentes;

- Fenômeno da natureza, exemplo: que a criança seja capaz de responder perguntas simples, envolvendo manhã, tarde e noite;

- Adequação do vestuário ao tempo. exemplo: que a criança classifique as roupas. de acordo com o tempo;

- Plantas, exemplo: que a criança seja capaz de dar dois elementos básicos para o crescimento das plantas:

- Alimentação, exemplo: fazer um levantamento, através de conversa, o nome de frutas que as crianças conhecem.

Sugestōes de Estratégia Corpo Humano

- Sentidos;

- Dentes:

- Cuidados de higiene;

- Provar alimentos com sabores opostos, exemplo: doce, salgado, azedo, levando as crianças a perceberem a função do paladar;

- Pedir às crianças que fechem os olhos, perguntando se estão vendo algo. Através de conversas, fazer com que, percebam os olhos como órgão da visão e sua importância;

- Vamos ficar bem quietinhos, vamos escutar tudo o que acontece. Vamos ficar com os olhos fechados. Levantar com as crianças sobre todos os sons que escutaram. Através de jogos, levá-los a perceberem o ouvido como órgão da audição;

- Com os olhos vendados, oferecer objetos para as crianças apalparem e dizerem o que é. Exemplo: laranja, banana, etc;

- Nestes jogos poderão. posteriormente, ser usados dois ou três sentidos juntos. Exemplo: a criança cheira, apalpa e coloca na boca;

- Usando os sentidos, as crianças agrupam os elementos com o mesmo cheiro, com o mesmo gosto, etc;

- Conversar sobre os dentes, sua função e os cuidados que devemos ter;

- Utilizar fantoches, onde as personagens vivem estórias relativas ao contet5do;

- Elaborar cartazes sobre os sentidos e os dentes;

- Através de conversas, com ou sem cartazes, introduzir noções básicas de higiene corporal. Exemplo: necessidade de banho, pentear os cabelos, escovar os dentes, etc;

- Estes aspectos deverão ser abordados várias vezes, na prática, o professor deve reforçar o comportamento adequado.

Fenómenos da Natureza

- Sol, lua;

- Chuva;

- Manhã, tarde e noite;

- As crianças serão induzidas a observar o sol, chuva, aproveitando todas as oportunidades em que estes fenômenos se apresentem;

- Num dia de sol, levar as crianças ao pátio, e através de conversa, encaminhar a observação para o sol, como ele é, o que estamos sentindo, como está o nosso rosto, etc;

- Colocar um pouco de água no chão e levantar a questão: o que vai acontecer? As crianças deverão observar e depois concluir; céu:

- Pedir às crianças que ao chegarem em casa, à noite, observem o que aparece no

- Através de conversa informal, a professora coloca as questões: “Antes do almoço o 
que nós vemos no céu? E depois, quando vai brincar, o que ainda se vê no céu? E a noite, quando estamos em casa, antes de dormir, como está o céu?";

- Elaborar com as crianças um cartaz, com o que aparece no céu durante a manhã, a tarde e a noite;

- Em um dia de chuva ouvir o seu barulho. Observar a chuva caindo na terra, nas plantas, no chão, no telhado, etc;

- Sentir a chuva nas mãos;

- Estórias dramatizadas;

- Observação diária do tempo - cartaz do tempo.

Adequação do Vestuário ao Tempo

- Observação do tempo relacionamento com a roupa que estão vestindo. Se o dia estiver frio. perguntar às crianças: "Se estivéssemos sem sapatos, sem blusa de lã, só com calção, como estariamos nos sentindo?";

- Jogos imitativos - imitar alguém andando na chuva, com e sem guarda-chuva. Imitar alguém com frio, com muito calor, etc;

- Recortar de revistas, gravuras referentes a vestimentas usadas de acordo com as diferentes temperaturas (frio, calor, chuva);

- Estórias em que são abordadas as necessidades de abrigo e proteção do frio, calor e chuva;

- Classificar as roupas de acordo com o tempo;

- Elaborar um cartaz, onde as crianças colocarão, diariamente, o bonequinho vestido de acordo com o tempo.

Plantas

Condições de Germinação

- As crianças serão levadas a observar a terra - remexer, molhar, transportar de um lugar para outro, retirar as pedras, os matinhos, descobrir bichinhos;

- Observar algumas plantas existentes no Cadi e ao redor dele. Observar o tamanho, as diferentes flores, a coloração, etc:

- Hora da novidade, alguns tipos de sementes de crescimento rápido;

- Levar as crianças a prepararem a terra para o plantio das sementes: afofar, remexer, aguar, etc;

- Acompanhar o crescimento das plantas, dispensando às mesmas um cuidado diário, exemplo: aguar;

- Algumas experiências podem ser realizadas para observar o crescimento e alimentação das plantas. Exemplos:

* Plantar no algodão, na água, na areia

* Colocar uma plantinha onde não haja luz e observar

* Observar o que acontece com uma plantinha quando deixamos sem água e concluir porque a água é importante;

- Colecionar diferentes tipos de sementes, folhas, flores;

- Desenho, colagem, pintura sobre as plantas;

- Jogos imitativos, exemplo: as crianças imitam uma planta bem pequenina, que é regada e vai crescendo bem devagarinho. Imitar o balanço das plantas quando venta. Animais Úteis

- Hora da novidade - levar para a sala: ninhos, penas, ovos, gaiolas com pássaros ou um aquário com peixinhos, cachorrinhos, etc;

- Lançar questões, tais como: "Que animais são estes? Onde eles moram? Eles silo nossos amigos? Por quê? Será que tomam banho?";

- Através de conversas, saber se as crianças têm algum animal em casa, e de que animal elas gostam mais. Levar as crianças a contarem de como cuidam dos animais, 0 que eles comem, etc;

- Levar as crianças a imitarem alguns animais;

- Fantoches cujas personagens são animais, contando sobre sua alimentação, sua habitação. etc.

Alimentação

- Verduras:

- Frutas: 
- Higiene dos alimentos;

- Levantar através de conversas, todas as frutas que as crianças conhecem;

- A ADI diz para as crianças: "Toda vez que eu disser o nome de uma fruta, vocês batem palmas. Se não for frutas, fiquem quietos.";

- Levantar com as crianças as verduras que elas conhecem

- Observar vários frutos, quanto a cor, forma, cheiro;

- Hora da novidade;

- Jogos de adivinhação - o professor traz uma fruta, dá algumas características, levando as crianças à formularem perguntas até adivinharem o que é;

- Visitar a cozinha para observar os alimentos crus e o processo de lavagem e cozimento, percebendo a modificação dos alimentos;

- Fazer colagens, onde só aparecem verduras ou só frutas que poderão ser pesquisados em revistas;

- Fazer colagens com sementes diversas:

- Desenho e pintura de frutas e verduras. 
Anexo 3: Termo de Consentimento Esclarecido (ADI) 


\section{TERMO DE CONSENTIMENTO ESCLARECIDO (ADI)}

Eu, concordo em participar, voluntariamente, da pesquisa cientifica sobre

"O desenvolvimento da linguagem oral de crianças no contexto de uma creche" que vem sendo realizada sob a responsabilidade da $\mathrm{Fg}^{\star}$ Andrea Wander Bonamigo.

Estou ciente da autonomia para determinar a disponibilidade de tempo e espaço à realização das atividades da pesquisa; de minha concordância em participar das entrevistas e filmagens a serem realizadas; de que será garantido o sigilo e o anonimato de minhas declarações e atuações na análise conjunta dos dados e de que a finalidade dos dados será única e exclusivamente para a realização dessa pesquisa.

Autorizo a divulgação dos resultados em conjunto e o resultado individual somente para a minha pessoa.

Posso, a qualquer momento, abandonar o estudo, sem prejuizo pessoal ou de trabalho.

São Paulo, de de 1998 
Anexo 4: Roteiro para as Entrevista 


\section{ROTEIRO PARA AS ENTREVSTAS COM AS ADI}

$N^{\circ}$ da entrevista:

Horário de início:

Horário do fim:

Instituição:

Idade da entrevistada:

Escolaridade:

Estado Civil:

Tempo de trabalho na instituição:

Qual o horário de trabalho na instituição:

Qual a faixa etária de seu grupo de crianças?

I. Você já teve alguma informação (em curso, palestra, treinamento) sobre o desenvolvimento da linguagem oral na criança?

( ) Sim. Fale sobre essa informação. ( ) Não

II. As atividades do dia-a-dia na creche.

A ADI discorrerá sobre as atividades do cotidiano considerando àquelas mais importantes ou os momentos em que a sua participação é muito importante para o acompanhamento das crianças.

\section{Concepçâo de linguagem oral}

Nesse tópico, a entrevistada se manifestará sobre sua concepção de linguagem oral.

\section{Processo de desenvolvimento da linguagem oral}

Fala da entrevistada sobre o desenvolvimento da linguagem oral, abordando os seguintes aspectos:

Como vê estas crianças enquanto sujeitos;

- Como pensa o processo do desenvolvimento da linguagem oral;

- Caracteristicas da linguagem oral nas crianças; 
Atuação junto às crianças nos momentos de higiene, alimentação e recreação;

Características da interação da ADI x crianças.

V. Participaçåo do adulto no processo de desenvolvimento da linguagem oral

Nesse tópico, a ADI se manifestará sobre a sua participação no processo de desenvolvimento da linguagem oral das crianças.

VI. Importância da linguagem oral no desenvolvimento infantil

Nesse tópico, a entrevistada discorrerá sobre o significado do aparecimento da linguagem oral nas crianças e sobre a importância desta linguagem como expressão do desenvolvimento infantil. 
Anexo 5: Caracterização das Entrevistadas 


\section{CARACTERIZAÇĀO DAS ENTREVISTADAS}

Para facilitar a contextualização das falas, apresentamos os dados pessoais de cada uma das $A D I$ entrevistadas. Identificamos as $A D I$ utilizando nomes ficticios para garantir-lhes seu anonimato.

Ana: 42 anos, escolaridade $1^{\circ}$ grau completo. Casada. Um filho que está sendo atendido pela creche. Reside nas imediações da creche. Foi auxiliar de serviços gerais antes de ingressar na instituição. Está exercendo as funções de ADI há seis anos. Grupo pelo qual é responsável: Matemal I.

Beatriz: 48 anos, escolaridade $2^{\circ}$ grau completo. Casada. Três filhos. Reside distante da creche. Foi secretária antes de ingressar na instituição. Trabalha há cinco anos na creche. Responsável pela turma do Jardim.

Anita: 38 anos, escolaridade $2^{\circ}$ grau incompleto, continua estudando a noite. Casada. Três filhos. Residente nas imediaçōes da creche. É atuante na comunidade. Foi inspetora de alunos de uma escola próxima a creche. Por algum tempo acumulou essa atividade com a de ser ADI. Há quatro anos trabalha na creche. Responsável pelo Maternal I.

Neiva: 28 anos, escolaridade $2^{\circ}$ grau (magistério). Solteira. Uma filha. Residente nas imediações da creche. Exercia a função de ascensorista antes de ingressar na creche. Há sete anos exerce as funçōes de ADI nessa creche. A turma de crianças que acompanha é o Jardim.

Tánia: 28 anos, escolaridade $2^{\circ}$ grau (magistério). Solteira. Um filho que a acompanha à creche. Reside distante da creche. Foi professora em uma escola de educação infantil antes de trabalhar nessa creche. Há cinco anos exerce suas funções no CADI. Atende o Maternal I.

Rose: 36 anos, escolaridade $2^{\circ}$ grau incompleto. Casada. Três filhos. Reside num bairro próximo. Foi por muito tempo diarista antes de ser ADI. Trabalha na creche há quatro anos e 10 meses. Responsável pelo Berçário. 
Marlene: 37 anos, escolaridade $1^{\circ} \mathrm{grau}$ completo. Casada. Dois filhos. Tem um dos filhos atendidos pela creche. Reside distante da creche. Antes de exercer as funções de ADI foi dona de casa. Há quatro anos trabalha na creche. Responsável pelo Maternal II.

Ivete: 43 anos, escolaridade $2^{\circ}$ grau completo. Solteira. Reside em um bairro próximo. Foi metalúrgica. Atualmente além de trabalhar como $A D I$, atividade que exerce, há cinco anos, também é feirante no bairro aos finais de semana. Responsável pelo Maternal II.

Joana: 36 anos, escolaridade $2^{\circ}$ grau incompleto. Casada. Dois filhos. Um de seus filhos é atendido pela creche. Reside em um bairro próximo à creche. Foi dona de casa antes de ser ADI. Há cinco anos está na creche. Responsável pelo Maternal II.

Maria: 43 anos, escolaridade $2^{\circ}$ grau incompleto, permanece estudado. Casada. Três filhos. Reside em um bairro próximo. Foi auxiliar de escritório. Há seis anos exerce as funções de ADI. Responsável pelo Mini Grupo.

Carla: 31 anos, escolaridade $1^{\circ}$ grau completo. Casada. Dois filhos. Um deles a acompanha à creche. Reside em um bairro próximo. Foi inspetora de alunos antes de ingressar na creche. Há quatro anos e 6 meses no CADI. Responsável pela turma do Matemal I.

Dana: 36 anos, escolaridade $1^{\circ}$ grau incompleto. Casada. Dois filhos. Reside na comunidade. Foi auxiliar de serviços antes de ser ADI. Trabalha na creche há cinco anos e 6 meses. Sua turma é o Berçário.

Paula: 39 anos, escolaridade $2^{\circ}$ grau (magistério). Quatro filhos. Reside distante da creche. Antes de trabalhar com crianças foi somente dona de casa. Há cinco anos está trabalhando na creche. Responsável pela turma do Jardim. 
Anexo 6: A Anălise do Discurso de Auxiliares de Desenvolvimento Infantil 
Nesse momento o direito à voz é das ADI. Por meio de suas falas, identificamos expressões que traduziram as vivências e experiências do cotidiano junto às crianças dessa creche pública.

Procuramos uma linguagem que permitiu que os discursos das ADI pudessem fluir quase naturalmente.

A fim de interpretar as falas das ADI, realizamos a leitura de todas as entrevistas, com o intuito de identificar elementos estruturadores dos discursos que pudessem ser decompostos em categoria e sub-categorias dispondo, assim, o eixo de análise dos mesmos.

Da leitura extraimos as informaçōes mais significativas, anotando o que se repetia ou se evidenciava com certa regularidade.

Chegamos a sistematização de cinco categorias que representam o eixo temático em tomo do qual os depoimentos das ADI se articulam, a saber:

1. Seu jeito de ver a criança, sua formação e o seu trabalho

2. O cotidiano na creche

3. A creche e o desenvolvimento das crianças

4. O que pensam e como acompanham o desenvolvimento da linguagem oral

5. A linguagem oral enquanto expressão do desenvolvimento da criança

Identificamos as ADI que participaram das entrevistas com nomes ficticios, como em geral se faz em estudos dessa natureza. 
Optamos pela apresentação genérica dos enunciados predominantes nos discursos das auxiliares do desenvolvimento infantil.

\subsubsection{Seu jeito de ver a criança, sua formação e o seu trabalho}

\subsubsection{A criança da creche, quem é?}

Quando solicitadas para falarem sobre a criança com a qual trabalham, várias concepções de criança foram reveladas. Algumas $A D I$ retrataram a criança com a qual trabalham como aquela descrita nos livros, por meio de conceitos abstratos com dimensão romantizada; outras falam de maneira saudosa da sua infância, a criança que já foram, a criança que gostariam de ter sido, a criança como os seus filhos. Verificamos em outros enunciados que a criança revelada é a concreta, contextualizada, parceira de vida e de mundo; a criança da creche, pobre e muito carente é então reconhecida como um ser em potencial desenvolvimento.

Os enunciados a seguir sugerem que a criança é pensada como ser movido de alegria, que proporciona emoção e satisfação às pessoas com as quais convive.

“Ah! Criança é tudo, né? Criança è vida. Criança é alegria, né? Pra mim é! (risos) (...) Bem, eu acho que tem que respeitar todas as crianças, seja minha filha, seja outra, seja qualquer um, entendeu? Então é por isso, criança para mim é tudo..." (Ana)

"Ah! Criança para mim é vida, amor, carinho, alegria é muito, muito lindo! Acho que uma criança é tudo, né? E quando você trabalha assim, gostando do que 
faz, nossal É muito gratificante. Não importa o salário, ordenado, nada. Só de você estar ali com eles é muito bom! Criança é sinceridade, amizade, sabe? Eles não estão cobrando a toda hora. Vocé fica a vontade com eles. É muito bom!" (Anita)

"Como eu vejo a criança? Eu vejo a criança assim, ela é inocente, ela é clara, a criança năo tem aquela coisa de mentira. Ela é clara, eu vejo a criança clara, ela năo é de mentir..." (Beatriz)

"As crianças do CADI săo muito felizes. Elas passam os dias muito felizes. Na casa delas não sabemos o que se passa, cada uma tem uma familia, um pai, uma mãe, a gente não sabe, quando elas põe o pé para fora, a gente não sabe o que se passa. Aqui dentro elas são felizes! Tenho certeza. Aqui elas têm de tudo: se alimentam, brincam..." (Rose)

Os seguintes depoimentos apresentam a criança como um ser incapaz que precisa da proteção do adulto.

"... Um ser humano, filho de Deus. Coitado, a criança é um bichinho, um bichinho,... um indefeso." (Ana)

"Eu vejo uma criança, como uma pessoa assim sem defesa nenhuma... e sei que eles me vêem como alguém que sabe de tudo... (...) Criança de creche é impossivel... é esperta..." (Ivete)

A idéia idealizada da criança está presente nos seguintes relatos, nos quais as ADI almejam a ascensão social para as crianças assistidas. Percebemos esta idéia por meio de suas falas, quando valorizam a escolaridade e o próprio trabalho e referem a expectativa do futuro. 
“... E a renovação do mundo! (...) Eles vão ser os médicos de amanhã, os politicos de amanhă, alguns vão cuidar de crianças que virão daqui muitos anos. Eles é que farão as descobertas, descobrir as doenças." (Rose)

"... Eu vejo assim como um futuro mesmo ..." (Tânia)

A criança é reconhecida por um sujeito presente no mundo, sem preconceitos e censuras, colocando-se como alguém que participa interagindo ingenuamente com outras pessoas. Nos depoimentos a seguir percebemos que ao mesmo tempo em que as ADI vêem as crianças como sujeitos de suas próprias ações, comparam-nas com os adultos e suas atribuições enquanto responsáveis pela manutenção de sua própria existência.

"... Ele fala "Ah, tia, gostei daquilo", ele chega, conta tudo, fala tudo, a criança é expansiva, né? Ela é clara, ela fala aquilo que ela acha, aquilo que ela vê, o que pensa. Eu vejo assim. Carinhosas. Eu vejo assim." (Beatriz)

“... ser criança é ser sem responsabilidade, querer atenção, năo precisa saber nada do mundo, eles querem saber do hoje, assim, é brincar, é comer, se divertirem, é conversar... é querer a atenção das pessoas, dos adultos, é isso. (...) As minhas crianças eu vejo assim: eles querem a atenção da gente, querem brincar, querem conversar, năo têm responsabilidades, não têm nada, são crianças,..." (Joana)

"Ser criança é muito bom. Sem compromisso, sem conta, sem assim dividas do que tem que fazer o que não tem que fazer, compromisso, hora, deve ser muito bom, muito bom!" (Carla) 
(...) "Ser criança é muito bom! Ser criança é não ter problemas, não tentar resolver problema algum, porque não os têm. Ser criança é maravilhoso. Queria ser criança novamente!" (Maria)

O depoimento de Neiva, no enunciado a seguir, revela que os afazeres das crianças nesta creche podem ser considerados como obrigações a serem cumpridas pelas crianças sob a supervisão de um adulto.

“... Pra mim é uma coisa muito importante, ser criança. Mas a criança tem muito mais obrigações do que um adulto, né? Ela tem que estudar... tá certo, tem as horas de lazer, de brincar, mas também tem hora de cobrar deles, tem lição de casa, tem que por horário porque pra eles tudo é brincadeira, né? É uma coisa muito feliz, é uma coisa que marca a vida, né?" (Neiva)

Uma, das entrevistadas $A D I$ que aqui denominamos Maria, ao prover as necessidades básicas das crianças, se vê como uma substituta materna, passando a assumir seu lugar, confundindo os papéis de mãe e educadora. Na sua fala percebemos claramente a sobreposição do papel de funcionária com o de mãe e a satisfação que isso the confere.

"Eu vejo como minhas crianças mesmos. Como minhas e não como se vocé estivesse prestando um favor para elas. Desde que eu entrei aqui, eu as trato como se fossem minhas. Tenho ciúmes delas com as outras tias (ADI). Eu vejo como minhas." (Maria)

Os depoimentos a seguir apresentam a criança como um ser potencialmente em desenvolvimento. Algumas habilidades são referidas denotando que essas ADI têm um olhar diferenciado às crianças com as quais atuam. 
Os enunciados expressam o reconhecimento da individualidade de cada criança.

O convivio e o afeto são também identificados nos discursos como elementos essenciais para que ocorra o desenvolvimento das crianças.

"Eu acho que cada um, cada pessoa é uma pessoa, cada um é diferente do outro. (...) Cada criança tem uma maneira de ser, um jeito." (Rose)

"É um ser humano em desenvolvimento e que precisa de uma companhia. $E$ um ser em desenvolvimento sensivel, uma coisa mesmo de carinho. (...) É um ser em desenvolvimento que precisa de carinho e atenção." (Marlene)

"Como vejo essas crianças? (pausa) Ah! Eu vejo como crianças perfeitas, com condições de fazer tudo o que a gente ensina. Elas têm condições de aprender. Crianças normais, às vezes a gente percebe, são crianças carentes. Mas são crianças normais capazes de aprender tudo." (Dana)

“... Criança é muito inteligente, né? Muito observadora, eles observam tudo, é coisa impressionante. Atê os pequenininhos. Nunca vi coisa igual. (...) ...É uma ou outra que tem uma dificuldade pela quantidade de crianças que a gente atende aqui. São muito espertos, são inteligentes, aprendem com facilidade tudo, seja uma coreografia, seja uma estória que se conta, num instante grava..." (Beatriz)

“Ah, são crianças, eles são assim... como chama, eles são muito agitados, mas assim dentro do seu limite, se você deixa. Eles têm energia, eles correspondem às atividades, têm uns que têm mais dificuldades do que os outros, mas sabe, eles superam." (Paula) 
As $A D I$ revelam nos depoimentos sobre como vêem a criança com a qual trabalham que esta percepção constitui a maneira como vão entender que devem assisti-la.

Algumas ADI, apresentam uma visão parcial da criança, o que impede, muitas vezes, de compreendê-la como um ser que se desenvolve fisica, afetiva, intelectual e socialmente, WALLON (1997).

As concepções que o adulto tem sobre as capacidades da criança em cada idade e os objetivos que seleciona para o seu desenvolvimento vão influenciar não apenas sua forma de estabelecer relações com a criança, como também na maneira como organiza o ambiente em que esta se encontra, OLIVEIRA (1994).

A seguir apresentamos as ADI falando sobre a sua própria formação, as suas dificuldades, o seu trabalho e a sua interação com as crianças no contexto dessa creche.

\subsubsection{Sua formação}

Os seguintes depoimentos apresentam o entendimento das $A D I$ sobre a sua formação em serviço e sobre o seu trabalho, na medida em que as suas experiências e vivências servem para que transformem as suas atuações na creche.

“... Eu fiz vários cursos, depois que vim trabalhar aqui. Fiz na APAE muitos. Sobre a linguagem, o desenvolvimento da criança, como desenvolver a linguagem oral na criança, brincadeiras, jogos. Como isso a gente vai observando a fala da criança, como eles falam. Dependendo do tipo de brincadeira: roda, fazer roda com as crianças, contar uma estória, pedir para que a criança conte essa estória, nisso você vai observando a memorização da criança e a linguagem. Como ele se expressa, 
qual a criança que está conseguindo falar mais corretamente, dependendo da sua faixa etária de 3 anos, de 4, de 5 e assim sucessivamente até os 7 anos de idade. Então, através de uma estória que você conta, pede para que a criança repita, e nisso você vai observando quem tem probleminha de fala, quem consegue falar melhor, quem consegue contar aquela estória com portuguesinho melhor, como você vai trabalhar isso e depois disso. Na roda você pede para que a criança repita bastante, que um conte a estorinha para o outro e com isso vai desenvolvendo a linguagem dele, aquilo que ele ouviu, que a educadora passou." (Beatriz)

"... participei de muitas reuniōes, palestras, com fonos (fonoaudiólogas estagiárias) que vinham aqui e falavam. Ai a gente foi percebendo o que elas falavam e eu tirava para mim no meu dia-a-dia. Então eu tive, né? Porque quando entrei aqui, eu entrei como mãe só, e agora eu tenho alguma base. Os encontros aqui foram muito importantes, muito, porque a gente é muito pequeno com as informações que têm, porque a gente vem de uma educação restrita, né? Chega aqui e a gente começa a conversar com mais profissionais, com gente mais entendida que foi buscar em outros lugares, entăo é muito importante isso!" (Carla)

"Curso eu não fiz nenhum fora, mas aqui já tivemos muitas leituras, treinamentos, reuniōes, que serviram para nos dar conhecimentos e segurança para o que estamos fazendo hoje, no trabalho de hoje. Quando nós entramos (referindo-se ao grupo de funcionárias), cada uma veio de um lugar, uma de casa, uma nunca trabalhou, outra de um hospital, ninguém sabia como lidar com a criança. Nós caímos assim, de paraquedas. Não sabiamos, mas precisávamos trabalhar. Eu nunca tinha entrado numa creche. Eu nem conhecia, no inicio foi terrivel, mas com aquele monte de cursos internos, palestras, reunióes, monte de coisas que serviu para formar o conhecimento que temos hoje. Foi riquissimo." (Rose) 
"A gente aprendeu muito, nossa, eu aprendi muito. Inclusive até mesmo na sala, foi bom eu até ter entrado aqui para trabalhar, porque gritava muito com as crianças (referência aos seus filhos), era um pouco violenta, até dava uns tapas, agora eu sinto muito o meu lugar. Nossa, a gente aprendeu muito! Particularmente eu aprendi muito! (...) Muitos temas foram abordados, sobre o diálogo com a criança, sobre a fala, agressividade, brinquedoteca, como lidar com as crianças,..." (Joana)

Estas ADI, foram modificando o seu entendimento sobre o seu trabalho na medida em que a sua experiência serviu para que transformassem os conceitos iniciais que tinham sobre a atuação em creche.

“... a gente teve apoio de alguns profissionais a respeito disso, porque tem muita gente que é leiga no assunto, não sabe como agir, e se a gente tem alguém atrás orientando, falando, dando um suporte, eu acho que se torna importante e legal. (...) ...aprendi muito, muito mesmo... aprimorando o trabalho, através do conhecimento. Quando a gente trabalha com profissionais, a gente acaba aprendendo mais ainda..." (Maria)

Depreendemos das colocações acima que o trabalho de boa qualidade no atendimento às crianças requer um trabalho especializado, orientado por técnicos das áreas de saúde e de educação, sendo que para algumas $A D I$, a presença direta do especialista seria essencial no acompanhamento do seu dia-a-dia.

Analisando tais enunciados, somos levados a reconhecer que o trabalho da creche deve considerar o investimento na formação em serviço de seus funcionários.

Percebemos a importância retratada aos cursos realizados, às palestras assistidas e às vivências realizadas na creche com ênfase para os momentos de discussão onde se proporcionava troca de experiências. Impressões que evidenciam que essas ADI estão 
incluidas no processo de participação e decisão sobre o seu próprio fazer. Demonstrando interesse em conhecer mais as teorias sobre o desenvolvimento das crianças e sobre o trabalho em creche.

O educador de creche também se constitui enquanto tal (sujeitos), nas relações e interações que estabelece tanto com as crianças, como com as familias e com os outros profissionais da instituição, OLIVEIRA (1994).

Consideramos as percepções das $A D I$ quanto ao papel que desempenham dinâmicas e que podem ser modificadas com a experiência, especialmente através de programas de formação em serviço.

A ADI Anita, exercia a função de auxiliar de serviço na creche. Há pouco tempo trabalha, diretamente, junto às crianças, portanto não participou dos treinamentos iniciais. Importante apresentar que no fragmento de sua fala deixa claro o quanto sente a não participação e a importância do contato com outros profissionais. Deixa, portanto, perceber que concebe o trabalho da $A D I$ como uma função que requer conhecimento $e$ formação específica. Sejamos a seguir:

"Fazer cursos para estar aprendendo mais para ver se essa tese de como eu trabalho com eles (as crianças) é realmente correta. Porque eu faço do jeito que eu acho que él $O$ que o coraçáo manda, com o amor que eu tenho. Agora, tem que ver se tudo o que eu faço também é correto, né? A gente tem que estar sempre aprendendo... (...) ...eu acho que ela (a creche) é muito importante, mas depende do trabalho que cada um esteja fazendo. Uma ADI da creche não pode estar ensinando sem ter uma orientação. A gente precisa sempre estar renovando e tendo orientação de como ensinar. Porque se entra na creche só para brincar, também não está dando atividades que estão puxando as crianças a falar, melhorar. Não vai. E também 
pessoas que nos ajudam também, né? Porque a gente não sabe tudo, a gente vai aprendendo de pouquinho." (Anita)

Acompanhando a trajetória das $A D I$ nesses anos de trabalho, percebemos que estiveram em busca de novas informações para desenvolverem suas atividades.

Questionadas sobre qual seria na opinião das entrevistadas o perfil de uma ADI para exercer as atividades de acompanhamento das crianças os enunciados abaixo retratam os seus pensamentos.

Ser paciente, carinhosa e educada são considerados atributos necessários para o trabalho junto às crianças. Observemos os enunciados:

"Primeiro, tem que ter vontade, vontade de trabalhar, vontade que dé certo. Depois que tenha um outro profissional que ajude, que esclareça, que dê palestras, é muito importante. A gente faz as coisas numa seqüência e com as palestras de um profissional, a gente conhece melhor, descobre coisas mais fáceis para chegar a uma criança do que como a gente acha que é certo! Tem que ter vontade, ter pique, eu acho que é isso! Náo adianta ela vir, assinar o ponto, entrar na sala e achar que vai acontecer alguma coisa. Náo! Tem que ter vontade, tem que estar a fim, tem que gostar das crianças também, que fica melhor para trabalhar." (Carla)

"Acho que primeiro precisa conhecer mais ou menos a cada criança, para saber como lidar, até como falar... às vezes eles chegam e perguntam coisas que a gente não está preparada para ouvir. É cada pergunta que a gente fica sem chão, sem saber o que fazer. Então eu acho que o adulto tem que ter uma... tem que conhecer, ter muita paciencia, saber a hora que ele vai falar e o que vai falar e como vai falar." (Marlene) 
“Ela (ADI) tem que ter primeiro, um bom desenvolvimento, né? Ela deve ser criativa, ela deve ter uma boa linguagem, ela deve ter uma boa postura, ela deve ter interesse, ela deve pesquisar livros, ela deve ler. (...) ...Você tem que ser firme e carinhosa, de uma maneira que ao mesmo tempo que vocé é boazinha com eles, vocé tem aquela postura dura também, qual é a hora certa de brincar, hora de jogar,..." (Beatriz)

"Eu acho que tem que ter vontade. Quem trabalha com criança tem que ter vontade de estar trabalhando com elas." (Tânia)

Para uma grande parte das entrevistadas, o critério fundamental para ser uma boa ADI baseia-se no sentimento. Gostar de crianças é visto como um pressuposto para a realização de um bom trabalho como também conceder carinho e dedicação que as crianças necessitam.

"Acho que resumindo tudo, a criança depende da gente, né? Depende da gente. Em primeiro lugar o amor, porque sem amor a gente não consegue nada, né? A tia tem que ter paciência, que já falei, carinho, dedicação, você tendo tudo isso... (...) o importante de tudo é ter amor. Se vocé tem amor à criança, você consegue tudo com ela, se você não tem amor, peça a conta do seu serviço e vá embora, que é a melhor coisa que vocé faz." (Ana)

"O adulto tem que ter muita paciência, dar um tempo para eles também, porque năo adianta em casa assim, a mãe lava a louça, lava a roupa e não dá muita atenção. A gente aqui não. Dá para dar atenção, se a gente senta na mesinha, senta no chão eles gostam disso. Em casa, às vezes, não dá esse tempo, para a mãe assim, chegar à noite e sentar e parar e ouvir eles. Então é importante o adulto ouvi-los, eles se sentem importantes com isso!" (Carla) 
Os depoimentos revelam que as $A D I$ se descobrem quando falam e analisam o seu próprio fazer.

Nesse sentido pensamos que as funcionárias desta creche exploram a possibilidade de serem sujeitos da sua história e, com outros parceiros, elaboram propostas, discutem, repensam suas identidades profissionais, lidando com a leitura de mundo, sentimentos e indagações frente a sua situação de educador, SANCHES (1998).

“.. o papel de uma educadora aqui. Não é só lavar bumbum, năo é só lavar bumbum da criança, fazer higiene total na criança, é trabalhar. Para isso nós temos esses materiais pedagógicos, temos uma brinquedoteca imensa, com tudo, sobre o desenvolvimento geral da criança, não só a fala, a psicomotricidade, o aspecto motor, visual, lingüístico, tátil, é só querer fazer." (Beatriz)

A ADI Maria apresenta na sua fala ressentimento ao pouco reconhecimento por parte da instituição do seu trabalho junto às crianças. Entendemos que a funcionária da creche deve sentir-se valorizada em seu trabalho, sem discriminação, numa relação dialética entre a reflexão e a ação.

"Era um sonho meu trabalhar com crianças pequenas. Eu me sinto muito beml Foi um grande sonho meu, trabalhar em escola, creche, era uma vontade que eu tinha. (...) Falta ainda muito conhecer, estudar bastante, ter bastante conhecimento, ler muito e falta o reconhecimento. Eu sinto assim, né. Pode até ser que eu tenha esse reconhecimento, mas que eu não estou vendo. Sempre está faltando algo na vida da gente." (Maria) 


\subsubsection{Seu trabalho e a interação com as crianças}

Observamos nos enunciados a seguir o grande prazer demonstrado pelas ADI na realização de suas atividades junto às crianças dessa creche.

“... eu me sinto realizada, viu? Porque eu nunca trabalhei assim, né. Depois que eu terminei o meu curso, larguei, recebi o diploma, pus na gaveta e fiquei cuidando de crianças, os meus né. Ai depois surgiu essa chance e eu vim... ah, eu adoro é uma coisa que eu faço que eu gosto de fazer mesmo, eu adoro trabalhar com aqui. Tanto lidar com as crianças quanto com os adultos eu gosto daqui, do meu trabalho." (Paula)

"Adoro. Gosto muito. Gosto muito. Gasto. Só não sei, estou me sentindo cansada. Mas gosto muito, muito, muito. Gosto. Aquilo que eu te falei. Me surpreendi, não achava que eu ia ter todo esse jeito pra isso, trabalhar com crianças... Gosto de criança, gosto de trabalhar com criança, gosto de artes, gosto de dar cademinho, gosto de chamar na lousa, gosto de vê-los contarem estórias, Eu gosto. Eu gosto." (Beatriz)

"Ah! Eles gostam. Eles se sentem muito a vontade comigo. Qualquer, probleminha que tem assim, eles vêm, eles me contam, me contam coisas que acontecem na casa deles. Até as mães falam, que quando ele chega em casa só fala "Eu quero ver a tia, ver a tia, ver a tia." Então eles se sentem a vontade, se sentem bem comigo, assim como eu me sinto bem com eles. Essa turminha do maternal l é assim, afetiva." (Anita) 
“Maravilhosamente bem. Gosto do que faço com as crianças, sei lá, tudo o que você faz, você vê. Vê retorno em tưo o que você faz. Você ensina alguma coisa para a criança e você vê que a criança apresenta aquilo para você, aquilo que você ensinou. E muito gratificante. (...) Eu adoro tudo o que faço, principalmente dentro dessa creche. Que eu amo muito! Trabalhar com as crianças para mim é a maior satisfaçăo, o maior prazer de ver as crianças crescendo, se desenvolvendo, aprendendo..." (Dana)

"Imagine a criança, com muita liberdade para se exporl Eu me orgulho do que eu consigol Eu do meu jeito consigo muita coisa com as crianças. Eu consegui desenvolver bastante, eu acho que isso é importante... Só o fato de conseguir carinho... demonstra que elas gostam de mim. Se eu falo "Por favor", elas sentam, isso para mim é uma vitória, acho muito importante. (...) É um trabalho de amor, graças a Deus estou realizada, estou. Estou feliz, se notal Legal você trabalhar e ver os resultados, né. É muito bom vocé trabalhar e ver os resultados." (Joana)

Encontramos na fala de todas as $A D I$ afirmações no sentido de que gostam muito das crianças e do trabalham que realizam.

A presença generalizada de um forte vínculo, que as ADI dizem estabelecer com as crianças em seu trabalho, também revelada em suas falas.

“... têm vezes que eles estăo mais agitados, estão mais calmos, têm vezes que eu estou mais agitada, têm vezes que eu estou mais calma. Outro dia mesmo eu estava nervosa ai uma criança perguntou por que eu estava tão nervosa. Tem crianças que ficam grudadas em mim, ficam direto, não saem, não desgrudam... Ai mando sentar e quando vou ver estão grudados em mim novamente. "Então porque a senhora está nervosa?" "Não estou nervosa são vocês que estão me deixando irritada." (Ivete) 
"Olha, logo no início em que elas chegam, quando a gente começa a trabalhar com as crianças é meio dificil, né. Ela vai se adaptando a gente, logo depois vocé já vê que tudo o que você passa elas logo já compreendem tudo o que você fala, a maneira de alimentação, atividades, tudo elas entendem bem." (Dana)

A necessidade do apego às pessoas, demonstrada pelas crianças é identificada nas falas de algumas $A D I$ quando se manifestam sobre a sua atuação.

"Elas (as crianças) ensinam muito para a gente. E tanto vai que a gente,... é assim, parece que a gente volta a ser criança de novo ..., é uma coisa que a gente nunca sabe o que eles vão fazer, é uma coisa que você nunca sabe o que eles estão passando. (...) E eu aprendi também com isso lidar melhor com os outros." (Marlene)

"... Do que elas querem brincar, elas brincam. O que elas pedem para a gente, a gente faz de tudo e faz para elas. Elas daqui não são de ficar pedindo muita coisa. Para eles o pouco que a gente consegue dar para eles, para eles está bom. Não são de querer, querer. Na minha opiniảo as crianças do CADI sáo muito felizes! Tanto é, como já falei, quando eles saem, eles querem voltar, eles sentem falta. A gente vê o olhinho deles, quando estăo do lado de fora. Aquele olhinho de "Ai, eu queria entrar"... (...) As crianças ganham presentes no dia da criança, todo o mês elas têm a festinha dos aniversariantes, mesmo que eles não tenham na casa deles, aqui eles têm todo mês... Eles têm brincadeiras, têm brinquedoteca, têm tudo o que uma criança precisa ter." (Rose)

A $A D I$ Ivete teve, na sua trajetória de vida, a vivência de transformar os fatos cotidianos (denominado por ela de "a escola da vida") em aprendizagem social. Este aprendizado evidencia-se no seu discurso em forma de sentimento e entendimento da criança e da creche. 
Essa ADI, quando fala de sua atuação deixa transparecer os sinais da repercussão de suas experiências passadas.

"Eu sou importante para eles. Como adulto que já passei pela fase deles e naquele tempo, naquela época eu não tinha ninguém que me levasse. Eu sei o que eu passei. (...) Se eu tivesse um adulto junto ... não teria sofrido tanto nessa vida. 0 adulto é importante porque mostra como fazer ... mas eu mesmo nunca tive ninguém, eu tive que aprender as coisas como eram na vida. Minha máe e meu pai são separados, não foram eles que me ensinaram, foi a vida." (Ivete)

Os seguintes enunciados sugerem que as ADI reconhecem a importância do periodo de adaptação das crianças na creche e delas próprias em relação às suas atividades como determinantes para a formação de vínculos.

"Eu me sinto bem! Não digo no começo, com uma sala cheia de criança, "O que eu vou fazer?", todos gritando. Você ainda não tem ainda aquela... os primeiros dias foram horriveis! Porque a criança não te conhece, você não conhece as crianças. Náo tem como você... Você fica assim, como um peixe fora da água. Mas com o tempo passando, nossal Muito maravilhosol Muito mesmol É muito gratificante. Uma criança te abraçar, conversar com você, chamar, na hora de ir embora vir e te dar um beijinho. Nossa, para nós, isso é muito importante. Para mim é muito importante." (Rose)

"Hoje eu me sinto muito mais útil. Já estou na sala sozinha, né. Mais responsável, eu me sinto muito útil. Eu sei que minha presença aqui é muito importante. (...) Eu acho que essa minha segurança de hoje, foi por eu estar trabalhando sozinha, porque no inicio trabalhávamos em dupla, tinha quem olhava, não olhar para incomodar, mas não decidia as coisas sozinhas, sozinhas. Mas hoje 
sou eu que decido, já controlo a sala, dou atividades,... Eu não acreditava em mim, tinha tanto medo, tanto medo,..." (Joana)

\subsubsection{O cotidiano na creche}

Existindo no cotidiano dessa creche uma prática estruturada sob uma rotina, solicitamos às $A D I$ que nos contassem como ocorrem suas atividades diárias junto às crianças.

Sobre a rotina da manhã:

"Quando eu chego... vou na sala. Primeira coisa: eu olho o caderno (onde as ADI registram os acontecimentos do seu turno de trabalho) se tem alguma coisa para passar para os pais. Com a chegada das crianças eu falo bom dia, porque eu acho essencial, digo "Bom dia", pergunto como estão com o pai e com a máe. Sentam e ai sempre têm novidades, que nem hoje mesmo, um foi ao zoológico, passear, uns é a roupa, outros o sapato, é aquela loucura, todos querem falar, e eu falo "Esperem, é um de cada vez." Ai entram. Quando todos já entraram, uns pegam revistas, sempre têm novidades, eles vão mostrando as revistas, nos jogos,... Ai quando eles vão embora, antes do café eu converso um pouquinho sobre o dia anterior, se tem alguma coisa no caderno, falo o que aconteceu... . Saio para fora, quando nós entramos, antes de começar a atividade eu faço com que lavem as máos porque estavam fora. Troquem as roupas, cada um guarda na sua mala, para não ficar aquela loucura de roupa. Ai sentam, deixo tudo se acalmar, para iniciarem as atividades bem calmos,... a gente tem um trato. Na hora da atividade eles não podem ficar se levantando para fazer xixi, beber água, conversar, porque é uma hora que eles têm que estar interessados para aprender, né.... Ai converso bem quando eu dou leitura, 
eles ficam quietinhos, que nem hoje... Só quando é discussão do livro que eles discutem, falam, querem conversar.... A gente faz atividade de salto, depois a gente escuta o som, ensaiamos um pouco. Converso um pouco sobre o comportamento deles, eu cobro muito o comportamento deles, cobro muito. Eu gosto de criança bem educada... Aí eu faço as atividades, cada um com sua caixinha, cada um também procurando cuidar do que é seu, eu falo para cuidar bem direitinho... vamos fazer a higiene, arrumar a sala eles mesmos, a maioria, tirando o C., o J.,... organizam a sala do jeito que eu gosto, cada um vai empurrando a mesa do jeito que eu gosto, onde eu vou, também dialogo bastante sobre o comportamento. No refeitório, eles agora eståo comendo direto com faca, já sáo mocinhos, tem que comer legal, para ficarem fortes,... Dai almoçam, escovam os dentes, é uma hora meio tumultuada, porque a gente conversa, conversa bastante... crianças né, porque eles aproveitam um pouquinho... Almoçam, comem a sobremesa, vêm, escovam os dentes... Procuro pedir para que eles não molhem o banheiro, escovam os dentinhos, porque chegam em casa e náo escovam! Eles sabem que têm que fazer xixi antes de deitar, bebem a água e deitam, só que eles ficam um pouquinho tumultuados,... E é isso aí o meu dia-a-dia, será que esqueci algum detalhe? E é assim eles văo dormindo aos pouquinhos, não săo todos que dormem de uma vez." (Joana)

"Logo entro na sala, vejo as crianças, vou conversando a respeito do que fizeram no dia anterior ou no final de semana, e deixo eles falarem bastante, alguns são bastante tagarelas; depois tem o café, a recreaçăo, que ai eu normalmente no meu planejamento deixo livre. Porque depende muito do estado do jeito das crianças, entăo é na hora que pego alguma coisa. (...) ai vem a hora do sol livre lá fora, para eles é uma liberdade lá fora, a gente tem que ir de um lado para o outro o tempo inteiro. Não dá para centralizar só no parquinho, não tem como. Tem o almoço, eles escovam os dentes, é uma loucura, todo mundo quer ir primeiro. Tem relatório, preparo de material,... e o dia continua." (Maria) 
Sobre a rotina da tarde:

"Eu chego, estão acordados, a gente vai conversando, porque eles não dormem mesmo. Sáo crianças que dormiram a noite toda, que acordaram tarde e não ficam dormindo. Ai, eu acabo dando banho naqueles que já estão acordados. A vai dando 13 horas, 13 horas e 15 minutos e vão todos acordando e aí eles pegam fogo mesmo. Porque um vai mexendo com o outro, levanta o colchão, troca o sapato. Dá aquela agitaçăo, mas é agitação de quem está acordando, está se vendo de novo. Na hora do café é tranqüilo. Depois do café eles vão lá fora, ai na hora de entrar a gente vai para o banho. Eu estou com uma dificuldade também com o banho, estou levando 1 hora para dar banho neles. Porque nem a calcinha, nem a cueca eles tiram. Entăo eu tenho que fazer tudo, pegar o sabonete, se for lavar a cabeça tem que ter cuidado com os olhos deles, ai tem que secar eles, parte por parte, colocar a calcinha, por meia, moletom, agasalho, eu estou levando acho que para todo o mundo, 1 hora, 1 hora e meia. E a atividade fica para o finalzinho da tarde, depois da janta." (Caria)

Percebemos descriçōes minuciosas do cotidiano de trabalho das ADI. Quando relatam o primeiro contato diário com as crianças, reconhecemos por meio de suas falas, que é considerado um momento importante, no sentido de garantir a atenção individual a cada criança no momento que chega à creche para depois integrá-la ao grupo.

A rotina diária fixa é questionada por algumas $A D I$, as quais sentem necessidade de transformar as propostas desenvolvidas em função das circunstâncias cotidianas.

"É bastante diferente. Uma que eu não gosto das coisas sempre iguais, eu gosto de mudar. Eu tenho o planejamento prás crianças que é feito pela equipe que faz o planejamento. Mas eu também mudo aquele planejamento. Não é porque ele está escrito ali, que concordo em tudo ou vou fazer aquilo. De repente, tem uma 
atividade que eu acho que posso transformá-la para ela ficar melhor, que eles vão estar prestando mais atenção, que eles vão estar melhorando e gostando muito mais. Então eu tenho a liberdade de estar mudando isso dali. Eu dou uma atividade que eu acho que eles vão se sentir bem e vou estar ajudando mais eles. Comunico pra ela (supervisora) que estou fazendo isso. E estou mudando o planejamento-às vezes sai, outras vezes não sai como espero. As vezes no trabalho com eles, não prestam atenção, mas eu repito aquele trabalho no final do mês, aquela atividade que não foi boa. Então um dia nunca é igual ao outro. Eu não deixo que um dia seja igual ao outro." (Anita)

A fala da $A D I$ Anita sugere que ela possui autonomia para conduzir seu trabalho junto às crianças. $A$ ADI revela a preocupação que possuiu de coordenar a rotina préestabelecida e o planejamento educativo da creche com as condições gerais do grupo atendido, tais como, motivação das crianças, envolvimento, atenção, condiçōes gerais de saúde, entre outras.

"Ahl O horário também, agora eu estou um pouco mais disponivel, eu estou mudando o horário... Se eu estou sentindo que eles querem se soltar mais, ficar mais a vontade, brincar mais, conversar mais, então eu saio um pouco mais cedo. Eu saio. Falo "Vamos respirar um pouquinho, vamos andar lá fora, vamos dar uma volta em tomo do CADI, vamos ver as plantas, os animais passando." Aí a gente, se solta, brinca um pouco. Quando eu vejo que eles estão bem relaxados eu entro e preparo minha atividade. Eu acho que ela rende muito mais do que se eu fosse fazer "Vamos fazer porque agora é horário de atividades..." (Anita)

Novamente a fala acima revela que o conhecimento das crianças de seu grupo, a interação com as crianças, a experiência acumulada, fornecem à ADI condições de transformar sua rotina para que as crianças participem mais, aproveitando todos os momentos sugeridos. 
Uma rotina bem construida dará parâmetros às crianças, situando-as no tempo e nos espaços durante as horas que passam na instituição quando se leva em conta a realidade das crianças atendidas, do espaço físico, dos recursos humanos e materiais da creche.

Essa rotina construída e cumprida pouco a pouco durante e em seguida ao periodo de adaptação, fornecerá subsídios para a formação de vínculos e proporcionará o desenvolvimento integral e harmonioso das crianças.

\subsubsection{As atividades realizadas na creche}

Entendemos como atividades realizadas nesta creche como qualquer ação promotora do desenvolvimento infantil, que envolva aspectos de estimulação, cuidados e interação. Não ocorrem apenas em momentos especialmente planejados, mas abrangem o que se passa nas trocas afetivas entre adultos e crianças e entre as crianças presentes em todas as atividades da vida diária dessa creche.

Para conhecermos as atividades educativas realizadas nessa creche, incentivamos às $A D I$ a se manifestarem sobre as ações programadas e realizadas junto às crianças.

"Eles contam o que se passa na casa deles, sabe, quem bateu em quem, quem comprou roupa, quem comprou sapato, contam tudo. (...) E eu diariamente faço roda de conversa. Eles estão acordando, eu coloco as cadeirinhas e eles vão sentando, né." (Paula) 
O relato anterior apresenta a roda de conversa como circunstância integrante do dia-a-dia dessa creche. Este fragmento sugere que a ADI realiza a roda de conversa para proporcionar a interação oral entre ela e as crianças e entre as crianças.

A roda de conversa é uma estratégia utilizada em algumas creches. Tem por finalidade garantir um espaço no qual ADI e crianças possam se manifestar, expressandose livremente sobre os mais diversos temas.

Diariamente a roda de conversa é proposta pelas ADI no início e no final de seus trabalhos na creche.

Os relatos a seguir revelam as atividades desenvolvidas pelas $A D I$ junto às crianças:

“... Eles já são grandinhos, até estão escrevendo o nominho, e eu trabalho bastante isso, porque já estăo grandes. Faço roda, conto estória, faço depois cada um contar a estória, depois em cima disso, faço com que eles desenhem a estorinha. Eu chego a contar até 3. Olha, é demais, pode até confundir a cabecinha, mas é que eles já são grandes. Depois eu faço cada um contar uma daquelas, "Quem quer contar uma do porquinho agora?" "Quem vai contar do chapeuzinho?" "Quem vai contar aquela que a tia contou, a da sereia?" E fico prestando atenção em quem vai... "Vamos ver, ela preferiu contar a da sereia." "Vamos ver como ela vai contar?" Depois disso ainda dou uma folha, para que cada um desenhe qualquer uma dessas 3 estórias..." (Beatriz)

"Teve um dia que pegamos o livro do peixinho a gente pescou bastante peixes na água. Aproveitei, coloquei em dupla, em grupo, menino contra menina e assim foi ótima a atividade! Têm atividades de equilibrio, são várias as atividades, com guache, gosto de fazer muito painel, eu gosto muito de trabalhar em grupo com 
eles. (...)Gosto muito de trabalhar com guache fazendo painéis, conjuntos, leitura,... Não são todos os dias que são folhas mimeografadas." (Joana)

"Tem a hora da leitura. E na hora da linguagem oral, sempre eu uso, tipo assim, leitura de estória, tipo assim, através de desenho, gravuras eu sempre ponho. Mando eles olharem e contarem uma estória. Coloco uma figura de um cachorro, por exemplo, "Invente uma estória com esse cachorro, o que vai acontecer?", "Imagine o que vai acontecer ainda"." (Paula)

“... eu dou papel, e principalmente na pintura, no desenho deles eu gosto de escrever o que eles fizeram. Quando é pintura livre, escrever o que eles vêem na pintura. Eu gosto de escrever. Eu estou na mesa na sala, eles mesmos levantam devagar, já levam na mesa para eu escrever (...) Uma vez tinha pintura com guache. Entåo eu pedi para eles dobrarem a folha de papel. Ai eles iam abrindo. Conforme abriam formava um desenho. Muita coisa que eu vi no desenho, sem perguntar, quando eu perguntava, batia. (...) Trabalho bastante com fantoches. Eles mesmos criam suas estórias. (...) Quando eles estão agitados, começo a contar uma estória (invento ou conto pelo livro mesmo). Eles acabam se acalmando." (Tânia)

"Ah,... tem o livro, a gente tem o diálogo. Pensar também que eles dialogam muito, não precisa nem estipular atividades, eles conversam, a gente conversa muito, então faz parte do dia-a-dia, eles conversam muito, eles têm liberdade, conversam, falam." (Joana)

"Olha, para falar a verdade, minha turma não gosta muito de atividade assim de ficar desenhando e colando, eles gostam mesmo é de brincar, sabe, dá um joguinho. Dá um joguinho para eles, você esquece que tem criança na sala. Fica aquele silêncio." (Ana) 
“... fantoches, é uma coisa que eles criam, entăo eu sinto que a hora passou a gente nem notou, não acabou e querem mais. (...)De repente vocé começa a contar uma estória e o tempo não é suficiente porque tem isso, tem aquilo, tem aquele outro, eles colaboram, eles participam. (...)E realmente quando eles se expressam eu sinto que é mais gratificante a atividade. Porque é assim, durante a semana a gente tem linguagem oral um dia, na parte da manhá e a tarde, e sempre que tem uma dramatizaçăo, uma música, noçăo corporal, realmente é bem mais gratificante, eles passam,... muito mais assim, como explicar, (pausa) sei que o objetivo é alcançado até ultrapassa o que se espera." (Marlene)

As ADI declaram em suas falas que as atividades educativas e recreativas são promovidas nas próprias salas das crianças. Nesses momentos as ADI propõem atividades como, desenhos, colagem, pintura, leitura, dramatizações, montagens de peças, fantoches, encaixes e jogos.

As atividades individuais ou em pequenos grupos nesta creche são planejadas e desenvolvidas a partir de temas contidos na literatura infantil. As indicações destes livros, que são utilizados na construção de atividades educativas mensais são sugeridas no planejamento. A escolha dos livros é realizada pelas ADI sob a orientação da supervisora.

Contam-nos as $A D I$ que ao final das atividades na sala a responsabilidade de organizar e guardar todos os materiais e jogos utilizados é das próprias crianças. Cada criança tem seu material individual (lápis, borracha, caderneta, tesoura, lápis de cor, entre outros) que armazena em uma caixa. A conservação desses materiais também é tarefa das crianças maiores. O enunciado a seguir reitera a importância dessa prática: 
"Acho importante porque eles têm que se organizarem. Eles comigo náo deixam nada à toa, até os brinquedos deles eles guardam, eles mesmos que ajuntam, - caderno deles eles mesmos carregam, na verdade têm uns que são mais desorganizados, mas está tudo lá. Eles mesmos vão lá pegam as coisas deles, colocam de volta, nas caixinhas e arrumam." (Ivete)

A música também tem o seu espaço nessa creche. Os enunciados a seguir revelam que as $A D I$ consideram as atividades musicais e sua participação nessas atividades como decisivas. Deixando transparecer que muitas vezes são as crianças que exigem a participação das $A D I$ nesses momentos. E segundo as suas falas, a música convida ao envolvimento, proporcionando muito prazer e alegria.

“Eles gostam que eu participo. Principalmente quando é para dançar, só que eu não gosto de dançar, mas eles querem que eu dance. E para cantar, eles querem que eu cante, ... , aí eu invento algo diferente. Eu não sei cantar essas músicas novas de agora, eles também não sabem e querem que eu cante. (risos) " (Paula)

“A recreação eles adoram, né? Você, tudo o que for brincadeira pra eles, eles adoram, tă? O que eles não gostam é de atividade de papel, papel eles não gostam. (...) Ah! Eu participo, canto, né? Dançar, nãol Que eu já não tenho pique pra isso. Ai eu começo cantar pra eles, ai eles começam a cantar, ai todo mundo canta, sabe? Eu acho que isso é que é gostoso: todo mundo participa, sabe? Na música." (Ana)

Podemos considerar como fundamental o papel do grupo na vida da criança, No grupo a criança aprende a conviver com outras crianças da mesma idade, com crianças mais experientes e de outras faixas etárias e com os adultos, o que significa realizar, permanentemente atividades coletivas 
O contexto dessa creche viabiliza a vivência em grupo e a brincadeira é essencial na vida da criança, porque a introduz na aprendizagem das práticas sociais, WALLON (1997).

"As meninas adoram é pular corda. Elas gostam muito. E os meninos de jogar bola. O que eles mais gostam é de futebol. Agora eles gostam de brincar de boliche. Eles mesmos se dividem e começam a brincar... (...) Agora que eles săo maiores, eles acabam se dividindo. Eu os deixo, para ver até onde eles vão chegar. E acaba dando mesmo certo. As meninas já sabem o que tem que fazer, elas vão. Eu ajudo a levar as cordas para elas. As vezes elas não sabem entrar no jogo, mas aprendem... (...) Ah! eu ajudo a bater corda para elas. As vezes eu organizo um pouco. Sempre tem um que esquece da hora, joga bola direto. Mando esperar. Têm alguns que não sabem esperar. Năo tem jeitol Agora o futebol é mais eles mesmos. Eles que escolhem quem vai ser o goleiro, quem vai ser isso, aquilo." (Neiva)

“Na recreação, geralmente aqui fora, às vezes eles ficam no gira-gira,... trago muito giz para fora, né, para ficar no chão. Hoje coloquei o maternal II lá, naquele lado, ficamos escrevendo com o giz no chăo, eles adoram desenhar, pulamos corda,..." (Joana)

“... As atividades de recreação, geralmente são feitas lá fora. Quando saímos para fora... Quando a gente está no pátio, damos uma atividade, como amarelinha, brincadeira de corda ou roda. Trabalhamos em grupo." (Tânia)

Identificamos nas descrições de brincadeiras coletivas que estas são acompanhadas pelas ADI no cotidiano da creche. 
Quando as ADI são levadas a analisarem a sua participação nas brincadeiras coletivas nos contam que possuem como tarefa providenciar os ambientes e organizar os materiais com os quais as crianças vão brincar.

Às ADI responsáveis pelo berçário e mini grupo cabe organizar o espaço a ser explorado pelas crianças.

Consideramos o espaço físico como um fator importante para o planejamento dos trabalhos na creche.

A exploração dos espaços proporciona condições de atenção, de dispersão, de liberação e contenção de energias, de dependência e independência, enfím, a capacidade da criança e do grupo de organizar o conhecimento do mundo, das linguagens, das relações entre eles e com os adultos.

Algumas entrevistadas revelam nos seus discursos que o espaço disponível para as atividades pode determinar as caracteristicas de sua atuação. Quando se referem às crianças menores de 3 anos, o espaço menor possibilita uma "fiscalização" mais eficiente por parte das ADI. Nas salas, por exemplo, as ADI podem se envolver com as atividades das crianças e ao mesmo tempo controlar a ordem do grupo e prevenir acidentes. Diferentemente quando estão com crianças maiores.

"Lá fora eu não deixo eles correrem. Eles ficam na calçada, né. Porque na grama têm as pedras, tem o barro, eu não quero sujar a sala, ai também eles podem cair, então ficam normalmente na calçadinha, levo alguns bichinhos, eles ficam brincando e uns 10, 15 minutos só para tomar um ar mesmo, dar tempo para tirar o lixo da sala. Não deixo que se afastem de mim. Eu atenta, eles não saem de perto, não deixo correr, de vez enquanto dou uma volta pelo CADI assim pelo redor, mas não deixo eles correrem, nem se afastarem também, então fica meio restrito ali fora, na 
sala eles ficam bem mais a vontade, com certeza. (...) Ontem estivemos na brinquedoteca. Ontem a proposta era livre e como está tudo em exposição fica dificil fazer uma proposta para eles, eles mexem em tudo. As meninas não pegam carrinho de jeito nenhum, mas os meninos mexem na cozinha, na penteadeira, nas bonequinhas, em tudo, os meninos exploram tudo, as meninas não, ficam com a cozinha e a penteadeira. Parece que já sabem, vão crescendo e sabem o seu lugar! (risos) E eles não guardam. Brinquedos, eles não guardam, entăo se você pegar um grupinho para guardar as panelinhas, o outro grupinho vai espalhando os carrinhos. Então fica aquela coisa, vocé vai para um canto e eles vão para o outro espalhar outro brinquedo. Agora na sala, como estão (os brinquedos) na caixa, quando eu peço para guardar, eles guardam. Mas também cobrando "Guarda se não na hora que sua mãe chegar você não vai embora, vai ficar guardando os brinquedos",..." (Carla)

“... Agora, lá fora a gente tem o parquinho, tem a bola, bambolê, boliche. Os meninos principalmente lá fora adoram chutar uma bola e as meninas no escorregador e gira-gira. Quando eu levo boneca lá para fora então ai é a festa. (...)Eu participo das atividades. Dentro da sala principalmente, lá fora é bem de leve porque o espaço é muito grande então eu tenho que por os olhos em cima deles mesmo. Então não dá para estar desenvolvendo tanto, agora dentro da sala principalmente quando passo as bonecas, brincadeira de casinha, tem espaço menor e dá para a gente controlar melhor. (...)Eu posso estar brincando e estar vigiando se tem algo em perigo, o que estão fazendo. Agora lá fora é mais complicado eu me envolver na brincadeira e correr o olho..." (Maria)

"Ah, eu gosto de participar. Se a gente está dando uma brincadeirinha. Por exemplo, eu gosto de dar relaxamento, a ginástica, assim, eu gosto de estar fazendo a ginástica, faço aquele relaxamento que vocês mesmo passaram com a bexiga, assim no corpo. Também deito para que eles passem em mim. Se estamos fazendo pesca, 
montei toda a farinha. Eu também pesquei. Para eles também estarem vendo que eu também estou participando. Não dá prá você dar uma atividade e querer que a criança renda se eu as colocar e deixd-las fazendo..." (Anita)

Encontramos na fala da ADI Beatriz a importância que ela atribui à participação do adulto nas atividades coletivas. Mesmo que impossibilitada de se envolver diretamente com as crianças por problemas médicos acompanha atenciosamente o seu grupo.

"Na recreação eu participo bastante. Agora, ultimamente, eu não estou participando muito. Eu levo tudo, fico um pouquinho mais sentada. Isso, eu não aprovo, acho que a tia, a educadora, a ADI, tem que no meio pular, mas eu estou com uma série de problemas no joelho, está dificil eu estar abaixando. Eu faço essa coisa de roda, pego a cadeirinha, sento no meio, já não sento mais no chão. Porque se eu sento não consigo levantar. Estou com esses problemas, ficando velha é fogol Então tenho que sentar na cadeirinha, outro dia levei coisa lá fora, queria pular corda com eles. Fui pular, nossa, me arrependi, só consegui dar um pulo e saí. Até fiquei com medo depois de voltar meu problema no joelho. Quer dizer não estou mais podendo participar com essas crianças. Nessas coisas de pular, sentar no chão, eu lá não estou mesmo podendo. O problema no joelho, uma série de problemas. Mas eu acho isso muito importante, tem que participar sim. Agora ultimamente, eu só dou o início, eu sento, observo,... Mas a tia tem que participar sim! Eu acho." (Beatriz)

\subsubsection{Os cuidados}

Existe uma preocupação em oferecer às crianças os cuidados básicos que the faltam em casa. Nos depoimentos a seguir percebemos que algumas ADI, exercem a 
função daquela pessoa que toma conta, que acompanha e que oferece os cuidados básicos de higiene e de alimentação.

"...E têm outras crianças que você fala "Vamos tomar banho?" Já vem assim, vem engatinhando. Eles adoram! Adoram tirar a roupa e ai choram para sair da banheira. Querem ficar no banho, não querem sair da água, querem ficar brincando na água. Eu falo "Vamos tomar banho, tomar banho!" Eles sabem o que eu falo “Hora do banho." Eu os levo para lá, eles já sabem. Os que gatinham vão atrás. Os que ainda não, ficam lá sentadinhos, choram porque querem vir atrás. Vou buscá-los. Eles ficam olhando, e eles gostam, gostam. Eles entendem quando se fala "Vamos para o banho?" Eles entendem!" (Rose)

"Eles adoram um banho,... Não sei se eles gostam do banho ou da bagunça que eles fazem no banho. Jogam água para fora, para baixo, um empurra o outro, tem que ficar de olho para não cair. (...) Ah! Eu fico de longe, falando "O, já passou sabonete ai no bumbum? Não estou vendo. Lava bem..." E assim por diante." (Ana)

"...Nem todas as crianças vêm bem higiênicas de casa, né? Mas eu tenho trabalhado um pouco mais à tarde e ai eu faço o banho, os cabelos, a unha, peço para a máe cortar as unhas, porque estão grandes. Se tiver um dinheirinho dá uma cortadinha no cabelo. $E$ até bom por causa dos bichinhos que dá na cabeça, né? Trabalho principalmente a dentiçáo deles, que devem escovar muito pouco. Tem sempre alguém com uma cariazinha, comida se estão comendo doce. Eu gosto de estar sempre escovando os dentinhos deles." (Anita)

"Pra mim é extremamente importante a hora da alimentação, eles têm que comer, às vezes eles não tomam café direito, mamam em casa, tomam aquela mamadeira e vem para cá sem tomar café. Ai na hora do almoço têm que comer,... 
Agora a higiene, escovar os dentes, eu participo junto com eles. Ensino, pego a escova também, fico lá fazendo, para eles fazerem, normalmente acabo eu tendo que ensiná-los. O almoço e a higiene são os momentos que mais necessitam de atenção." (Maria)

Os fragmentos dos discursos apresentados revelam que as ADI consideram os cuidados de higiene e alimentação como atividades educativas e que participam ativamente desses momentos junto às crianças.

Uma ADI, ao falar sobre sua participação no almoço com as crianças, conta-nos uma experiência vivenciada. na qual o diálogo com as crianças parece ser parte integrante do seu dia-a-dia.

"Eu sento junto, inclusive eu já tenho a cadeirinha que eles vão buscar em qualquer lugar que é da tia... Sexta-feira, quem foi que botou lá, ah, o N. "... tia o N. pegou, quer que a senhora sente com ele lá." Ficou na ponta de lá. Quando foi na quinta-feira o W. pegou (uma cadeira) e eu tive que sentar ali no meio com eles. Eles adoram que eu sente. ... Cada dia um pega e quer que eu sento do lado deles... E aí, "Tia quer que eu pegue o páo?" Então eu como pão junto, tomo café com leite junto... De vez enquanto tá lá... "Ops... vai disparar o ziper." "Mas tia, ziper? Se botar o ziper eu não como." Achei tão interessante quando falou isso. A criança é terrivel, né? Mas eu quis dizer ziper de conversar, porque era para comer... Quer dizer, eu participo junto e muito, né? Sempre fui assim de sentar junto com as crianças." (Beatriz)

Ressalta-se por meio dos fragmentos analisados que o educativo nessa creche passa pelo atendimento às necessidades da criança, pela necessidade de escuta do seu choro, do seu pedido, da sua exigência, como também pelo contato corpo a corpo, pelo cheiro, pelo afeto e pelas interações estabelecidas entre as $A D I$ e as crianças. 


\subsection{A creche e o desenvolvimento das crianças}

Incentivamos as $A D I$ a falarem sobre o desenvolvimento das crianças nesta creche. Seus depoimentos revelaram a intenção sempre presente de comparar as crianças atendidas com aquelas que não freqüentam a creche.

Nas descrições das ADI, a criança desta creche constitui o motivo de todo o trabalho realizado por elas.

"A creche contribui muito para o desenvolvimento da criança, muito, porque a gente está para isso, a gente náo tem que lavar uma louça, não tem que fazer uma mamadeira,... está na sala só para isso. Se a gente quer alguma coisa a gente pede para alguém, então a gente está ali só para estimular a criança mesmo, então é muito importantel Comparando o meu filho mais velho com o meu bebé que está aqui, nossal Ele falou muito depressa, andou muito mais depressa aqui, porque tinha uma pessoa especial para ficar estimulando. $O$ meu bebê andou com 10 meses aqui, enquanto que o $R$. andou com 1 ano e 2 meses e falou com 10, 11 meses. $O M$. com 6 meses já estava falando alguma coisa, já estava batendo palmilha. Então quando tem uma pessoa disponivel para ficar estimulando, é muito melhor! A creche tem isso de bom. A tia fica só estimulando a criança, a mãe não. A mãe tem que sair, fazer comida, então não pode ficar estimulando mesmo a não ser na hora da troquinha, que năo passa de uns 15 minutos, né? Põe para dormir, fica assistindo televisão, enchendo. Aqui na creche não. Bem ou mal está toda a hora uma tia falando, falando perto, passando a mão nele, então estimula bastante sim!" (Carla)

"Aqui não, aqui a gente faz com que a criança aprenda a se virar sozinha. E claro que você no inicio orienta, não vai deixar ele colocar a roupa virada, porque eles fazem tudo errado. Você vai lá e ensina a fazer certo, explica como faz, "A parte maior é atrás, a menor é na frente. (...) Aqui a criança tem tudo e nós fazemos de tudo pela criança, aquil Nós nos desdobramos, a gente faz o possivel e o impossivel. 
(...) Aqui não, aqui a criança tem o dia tomado, atividades, um monte de coisas. 0 CADI está voltado para as crianças!" (Rose)

“Muito importante a creche, porque ai ela se sente que não está sozinha. Ela sente que sempre tem alguém perto dela e isso a deixa tranqüila. Eu acredito que sim. Tem mais confiança, não tem medo, não precisa se esconder, ficar num canto. (...) ... faz diferença, e como faz, para tudo, para comer, ela não comia, era uma criança apática, não dava um sorriso para ninguém, agora ela está descobrindo o mundo agora." (Marlene)

“... Num instante eles aprendem a desenhar aquela estória no papel, a fala rápida, num instantinho aprende a falar. Eu vejo até do mini grupo, que num instantinho, aquilo que eu te falei, você vai trabalhando rapidinho eles começam a falar. Eles sabem mais que a gente de quem é a bolsa, de quem é o sapato, de quem é a blusa, de quem é quem. Desde os pequenininhos do mini grupo. Se entramos lá, eles mostram..." (Beatriz)

"Com certeza, a creche é muito importantel Por exemplo, se a criança fica muito só com os pais, ela fica muito assim, uma criança assim muito reservada, só para si. A creche é tanto importante nas atividades que oferece, como também na companhia que ela encontra com outras crianças. Uma criança com outra aprende melhor. Têm vários momentos em que a sala fica com outras crianças maiores, os pequenos ficam com os maiores. Eu acho que com tudo isso a criança está se desenvolvendo. E as atividades oferecidas ajudam bastante!" (Dana)

"Eu acho importantíssimo o papel da creche, demais! Nossa, demais! Não só para a fala, para tudo. A criança na fala não tem só a tia, ela tem o redor dela. Os outros funcionários, que muitas vezes passam e conversam com ela, isso eu acho fundamental na creche. Tanto é que as minhas crianças de 4 a 5 anos são poucas as que falam errado... Todo esse tempo bom que a gente passou, o diálogo, essa 
coisa de não gritar, de conversar, as atividades eu acho muito ricas, as atividades são muito ricas demais, as crianças daqui, elas saem preparadas para fazerem um pré ou um primeiro ano..." (Joana)

Os depoimentos expressam a preocupação das ADI em organizar atividades estruturadoras de interações crianças-crianças, adulto-crianças e criança-mundo físico e social entendendo que por meio dessas experiências a criança se desenvolve.

As crianças, nesta creche, vivem, convivem, exploram, conhecem e vão construindo uma visão de mundo e de si mesmas, constituindo-se como sujeitos, com a parceria constante do adulto.

A creche é um dos contextos de desenvolvimento, OLIVEIRA, ROSSETTIFERREIRA (1989). Além de prestar cuidados físicos, ela cria condiçōes para a criança se desenvolva cognitiva, simbólica, social e emocionalmente.

"Uma creche que facilita o desenvolvimento das crianças eu acho que deve ser que criativa, que dê oportunidade aos funcionários para trabalharem, como eu acho que o caso daqui mesmo, eu acho que os funcionários têm possibilidades de estarem trabalhando, e deixarem as crianças fazerem. Na medida em que os funcionários têm oportunidade de trabalharem, têm condiçōes de oferecerem coisas que as crianças possam aprender." (Dana)

"Um ambiente estimulador é um lugar assim com figuras, é um lugar com luz, é um lugar tranqüilo, e é um lugar que tem uma pessoa, um adulto, que tenha adulto, que fale um de cada vez, que respeite a fez do outro e com isso a criança observando isso, eu acho que ela com certeza vai falar melhor, vai esperar a sua fez de falar, saber a vez de falar, saber se comunicar bem. Um ambiente que não é, é um ambiente cheio de gente falando assim um por cima do outro, gente brigando, ambiente escuro, um ambiente vazio, e a criança observando isso, eu acho que fica 
muito complicado para ela. Ela pode até falar, mas eu acho que terá dificuldade para se expressar. (...)O ambiente de uma criança que não fala deve ter pais ausentes, uma criança que é colocada para dormir muito, uma criança que é colocada quando acorda em frente à televisão, uma criança que receba mamadeira só, que não dê nada para ela mastigar, uma criança que não brinca, uma criança parada, eu acho que é uma criança calada. Ao contrário da outra que é estimulada." (Carla)

"A creche é importante para tudo, não só na fala, daqui eles vão sair... preparados para quê? Para tudo, né? Como as crianças do maternal II, eles têm aqueles objetivos que vão alcançar, todas as salas têm o seu objetivo e juntando os objetivos do berçário para cá, eles vão sair com uma carga que poderão entrar numa EMEI que eles estáo bem, desenvolvidos, com a percepção desenvolvida, a linguagem, só as crianças que têm algum problema é que não saem. Eles saem bem daqui, saem alimentados, sadios, tem o acompanhamento da M. (auxiliar de enfermagem), tem tudo aqui. (...) Eles (as crianças) se tornam independentes. Na creche é o principal!" (Paula)

“... Tudo isso que a gente faz é sempre pensando na criança, na fala da criança, no desenvolvimento global da criança; na familia, porque eu acredito que a familia de cada criança daqui, eu tenho a certeza de que eles observam isso. Eu aqui tenho a certeza, que eles notam a diferença de seu filho sim, a partir do momento que ele entra aqui, que começa aqui no berçário. O desenvolvimento é outro em tudo, desde a higiene, a lingüistica, oral, visual, tátil, tudo, tudo. Eu acho que até a familia também deve perceber isso. Percebe, com certeza, porque fica a olho nu o trabalho que é feito aqui..." (Beatriz)

Com muita veemência a fala da ADI Beatriz expressa a importância do trabalho dirigido às crianças nessa creche. 0 desenvolvimento de habilidades por parte 
das crianças é latente e facilmente identificável pelos funcionários da creche e também pelos familiares.

“... Fico muito triste quando vejo que esse trabalho não tem um acompanhamento lá fora. Por exemplo, as crianças saem daqui e não tem um acompanhamento que eu acho que deveriam ter. Que eu acho que aqui as crianças são muito bem acompanhadas, săo muito bem instruidas e eu acho que esse trabalho deveria ter uma continuidade. Que nem eu, que moro aqui no bairro, eu vejo muitas crianças que passaram aqui, que vocé vê que tem todo um acompanhamento e depois você vê a criança aqui na rua, praticamente sem assistência nenhuma, que a mãe sai, tem que continuar a luta, tem que continuar trabalhando e nisso o filho náo tem onde ficar." (Dana)

“Observe uma criança de fora e uma criança daqui: têm muitas diferenças. As crianças daqui elas param de usar fraldas mais cedo, sem aquela pressão. Não tem pressáo. Tiramos as fraldas deles e eles aprendem naturalmente e não gostam mais de fraldas... E as de fora, crianças de 2 anos quase 3 anos, usando fraldas. (...) Aqui nas salas a criança aprende, ela tira a roupinha dela, ela sabe tirar, sabe se vestir. E uma outra criança năo aprende com essa facilidade. A gente em casa, o ambiente é outro." (Rose)

"Olha para começar o CADI para essa região já é importante para eles não ficarem na rua ou pra não estarem em casa sozinhos, porque muitas, as mães têm que deixar bebês de 3 anos com outros de 6, 7 anos para poder trabalhar. Então o CADI é importante pra eles em tudo. No crescer, na alimentação, no educar, acaba a gente educando essas crianças, porque elas passam o dia inteiro, né. Então o CADI é importante sim." (Maria) 
“... em casa, mesmo o pai com a criança, o filho vai falar a gente fala "Ah! Não tenho tempo." Ou você está fazendo outra coisa. "Oh! Depois você fala." Você está cortando ela de falar. Então ela não fica a vontade para falar, aquela coisa. Então ela vai ficando reprimida ali. Dai quando ela vem para a creche, se solta, tem uma coleguinha, estão na mesinha juntas, estão sempre ali, dorme, toda vida é mais fácil para ela conversar." (Anita)

Os depoimentos acima supõem importante as mães terem um lugar seguro onde possam deixar os filhos com tranqüilidade. evitando que a criança fique presa em casa ou solta na rua.

Esses enunciados também evidenciam a preocupação das ADI quando constatam que após o término do periodo em que a criança tem direito à creche (referindo-se a idade limite de 6 anos), ela retorna ao convivio dos problemas sociais e econômicos que cercam a sua comunidade, como violência, relações interpessoais conflitantes, falta de emprego, entre outros. E por permanecerem, agora, menor tempo na escola, as crianças poderão ser envolvidas pelos problemas mencionados acima.

O contexto creche deve garantir às crianças o direito à brincadeira, à atenção individual, ao ambiente aconchegante, seguro e estimulante, ao contato com a natureza, à higiene e à saúde, à alimentação sadia, ao desenvolvimento da curiosidade, à imaginação e à capacidade de expressão, ao movimento em espaços amplos, à proteção, ao afeto, à amizade, à expressão de sentimentos, a uma especial atenção durante seu periodo de adaptação à creche e ao direito de desenvolver sua identidade cultural, racial e religiosa, CAMPOS, ROSEMBERG (1995) 
3.2.4. Como pensam e acompanham o desenvolvimento da linguagem oral

As $A D I$ ao serem motivadas a falarem sobre o que pensam acerca do desenvolvimento da linguagem oral explicitam a importância atribuida ao convivio social nas instituiçōes como determinante para que esse desenvolvimento aconteça.

"... observo que aqui na creche as crianças falam bem mais rápido. Sabem se expressar com mais facilidade do que uma criança de fora. As ADI que ficam ali, dando atividades, atividades e brincadeiras. Brincadeiras instrutivas para que a criança vá aprendendo, assimilando, todos os dias com aquilo. Todo o dia conversando, falando e pedindo, eles acabam assimilando com maior rapidez. (...) Faz diferença a criança estar com outras crianças para o desenvolvimento da fala, eles precisam estar com o outro da mesma idade. Eles precisam brincar um com o outro, eles batem, eles aprendem a se defender, eles aprendem a se comunicar,... e a criança sozinha é diferente..." (Rose)

"O desenvolvimento da linguagem oral das crianças na creche é um pouco diferente, porque tem mais estimulos, tem mais do que em casa, tem mais crianças para eles conviverem..." (Paula)

Com o propósito de identificar o que pensam e como acompanham o desenvolvimento da linguagem oral de suas crianças, solicitamos às ADI que discorressem sobre as características da linguagem nas diversas faixas etárias.

Em praticamente todos os depoimentos que se referiram ao berçário. foi explicitado que a imitação pode ser constituida como o instrumento básico para 0 desenvolvimento da fala. 
De acordo com a perspectiva sócio-interacionista que assumimos como modelo teórico desta pesquisa, o desenvolvimento da linguagem oral inicia-se a partir do momento em que se dá a sua inscrição na ordem do simbólico, ou seja, desde o nascimento. Segundo LIER, (1983:12) "a criança ao nascer é incapaz de interagir lingüisticamente. existem restriçסes gerais para isso, ou seja, razóes de ordem biologica, psicológica e até mesmo sociais, suficientes para impedir a comunicaçăo lingüística, que, como forma de conhecimento, deve ser construida."

Sendo assim, cabe ao adulto interpretar as açōes das crianças, pois ao interpretálas atribuem forma e sentido fazendo com que a criança seja representada como um sujeito.

Vejamos os enunciados a seguir:

"Olhar, ver o outro estar falando, as crianças do berçário vão cuidando o som da fala, vendo o movimento da boca. Eles são espertinhos também. É uma coisa da natureza, um dom divino, a fala! Quando a gente está falando elas olha os movimentos dos lábios, por isso é importante a roda da conversa. (...) Os que já falam a gente olha, mas prestamos mais atenção aqueles que não estão falando direito..." (Maria)

“... eu acho que a gente estimula bastante também, no dia-a-dia você ao trocar uma criança você está conversando, você está brincando, vai estar conversando. Você percebe, no berçário por exemplo, que a criança presta muita atenção ao que você fala, ela não te devolve assim com palavras, mas de repente ela está brincando e sai, querendo não falar a mesma coisa que você fala, mas já imita bastante o que você falou, /papai/, /mamãe/." (Dana) 
"Vamos fazer xixi?", "Tá na hora do cocô!" Então, você pode perceber, você vai no berçáriol, as crianças já sabem praticamente, querendo ou não, eles sabem falar /xixi/, /cocô/, porque são as palavras que mais se repetem para eles aqui nessa creche... É um sons que eles começam a aprender e aprender a falar com a gente, mesmo que eles não falam que querem fazer cocô, só de você falar "Tá na hora de fazer xixi", as meninas já começam a descer as calcinhas e os meninos já começam, aqueles que são já mais espertinhos já vão descendo as calcinhas." (Ana)

"Palavrinhas, eu acho que 5 meses. 5 meses está falando /mama/ no caso, pode ser que nem seja /mamãe/, mas ela começa falar isso e a gente acaba entendendo isso (...) Acho que é a mãe mesmo. Quem está perto dela, conversa muito com ela, mexe muito, né? “Ai, que bonitinho, vamos papar?" Começa... Aí a criança vai com o tempo pronunciar. As vezes ela fala /mamal /papal. Essas palavrinhas. Acho que é com as conversas que tem com ela, que o adulto tem com ela, né? Sempre conversando, sempre mexendo, vai entrando alguma coisinha e ela vai falando com o tempo." (Neiva)

"As crianças do berçário falam com gestos, com as mãos. Eu sempre ia atrás deles e eles me mostravam o que era. Eu entendia o que eles estavam falando. (...) E eles me entendiam pelo o que eu fazia as coisas, pelos gestos, pelo jeito que eu os colocava, pelo modo de falar." (Ivete)

"Acho que tem que ter uma dosagem, acho que o carinho é muito importante. A criança precisa... (...) Eles olham muito para a gente, olham como a gente fala, a palavra certa." (Marlene)

As ADI motivadas a se manifestarem sobre quais os aspectos que contribuiriam para que o desenvolvimento da linguagem oral ocorresse, citaram a importância do estimulo dos adultos sempre presente, a alimentação como meio de estimulação das 
funções orais como mastigação. sucção. deglutição e fonação e o afeto proporcionando segurança à criança para ela se expressar.

“... Eu acho que tem que ter muito afeto da mãe, eu acho que o aleitamento materno contribui bastante, né? Ele se sente, uma criança segura, né? Porque ele tá sentindo o calor da mãe, a mãe ali nisso, que tá dando o peito, ao mesmo tempo que tá passando a mão na cabeça, na cabecinha, tá conversando com suas crianças, e eu acho que isso contribui e muito. É um fator primordial. Isso até falar a primeira palavrinha dele... depois quando vem para o CADI que já não tem mais esse aleitamento materno, mas ele vem prá cá com 6, 7 meses, então ai vai gerando o banho das ADI, que vão dando o banho, vão conversando com a criança no banho, dão alguma coisinha na água e vai conversando. Tudo isso é contribuição para que ele comece falar sua primeira palavrinha, que é em torno de um aninho." (Beatriz)

"Desde pequenininha a G. a cada mês falava uma palavra nova. Cada mês ela falava uma coisa. Ela falava uma palavra e outra. Então o estimulo do adulto para com a criança é muito importante. (...)Ela fala muito mais coisas do que uma criança da mesma idade. (...) ... eu acho que é mais estímulo dos pais, da familia e daquele que está em contato direto com a criança." (Tânia)

"Com o bebê tem que cantar muito. (...) Na hora do banho, na hora do trocar, também conversava muito com eles. Eu gosto muito de bebês, sou apaixonada por crianças! A comunicação deles, assim no caso, era o sorriso. Quando trabalhei no B I, 7 e 8 meses, o /a/ eles falam muito. (...) Agora o verbal assim, era o que eles pronunciavam mesmo /mã/ (mãe), e o sorriso, a gente ganhava muitos sorrisos, até hoje eu ganho deles." (Joana)

"... Mesmo os bem pequenininhos, eles entendem. Quando eu falo que não. quando eu falo que pode. Quando eu brinco com eles no chão, deito, eles 
entendem, rolo com eles, eles entendem e se sentem bem comigo. Eu sinto isso. (...) Quando eles pegavam alguma coisa do chão que não pode, porque é sujeirinha, eu falo (sinalizando) "Não. Não pode." (fazendo sinal de não). Eles aprendem. Aprendem. Fazem com a mãozinha igual também. E quando pode 'Você quer mamadeira, papá ou mamá?" Eles fazem sim. Os bebês se comunicam muito por gestos." (Rose)

"Eles começam a partir de gestos, com a estimulação, com gestos, com o choro mesmo que eles se manifestam, eles querem comunicar o que estão gostando, o que está incomodando..." (Paula)

Para as ADI os gestos manifestados pelas crianças além de constituirem um meio de comunicação são também respostas às palavras dos adultos.

"A criança menor depende muito de você. Ela depende de você praticamente prá tudo, na alimentação, na hora de trocar as fraldas, atividades assim, um pouco diferentes e a criança maior já se vira sozinha, ela sabe se comportar sozinha, vai ao banheiro, ela já sabe pedir que quer fazer xixi, cocô. Se ela está com fome, ela sabe expressar o que quer. O menor a gente já tem que mais ou menos adivinhar o que eles querem. À medida que você vai se acostumando com a criança você sabe tudo o que a criança quer, o que sente." (Dana)

Os depoimentos a seguir evidenciam que para as ADI o aparecimento da linguagem oral mantém estreita relação com a exploração do espaço.

“... a partir do tempo em que eles começam a engatinhar, pequeninos, que eles estão deitadinhos lá, quietinhos. Depois começam a engatinhar, a pronunciar alguma coisa, resmungam, ficam resmungando, ai começam a engatinhar, começam querendo te chamar. Pra mim, eu me sinto muito realizada, quando eles começam a me chamar, começam a balbuciar as primeiras palavras, começam a andar, ai começam a falar mesmo." (Rose) 
“Não sei se ela se sente mais liberta (referência a conquista do espaço pela criança), a liberdade que ela sente, já começa a falar, já começa a querer, por exemplo no caso do berçário, já começa a querer tirar a fralda junto. Se o colega está no piniquinho, eles já começam a despir a fralda e já começam a falar /xixi/, /xixi/. Quando a gente vai para o refeitório, já coloca o babador e já começam a /papá, /papá. Parece que é aquela liberdade de sair andando... (...) ... quando a criança começa a caminhar, ela desenvolve a fala mais rápido. É a mesma coisa que vocé... uma coisa assim, que ela desenvolve bastante a fala. (...)Eu acho que é quando a criança começa a caminhar, ela desenvolve a fala mais rápido." (Dana)

Na medida que o domínio motor das crianças vai se especializando com o passar do tempo em função das vivências cotidianas fornecidas pelos adultos na creche, as emissões orais acompanham a comunicação gestual como uma expansão do repertório de comunicação. E, com o desenvolvimento a linguagem oral vai representar as ações motoras.

Em relação às caracteristicas do mini grupo a presença da linguagem oral mais desenvolvida é reconhecida pela ADI. As crianças de 2 a 3 anos já utilizam as palavras para se comunicarem com as outras crianças e com os adultos.

"Falavam pouquinho e agora estão falando muito mais. Estão se soltando muito..." (Anita)

“... eles começam a imitar a gente, assim, os objetos que eles querem, colo /tolo/, chupeta, que não é chupeta é /peta/, leite que eles tentam falar leite /mamá/ alguma coisa assim. Eles começam colocar o nome, observando a gente também. A gente fala chupeta e eles não conseguem falar chupeta é /peta/, a gente fala 
mamadeira eles falam /mamál para mamadeira e a água.(...) Com 2 anos já começam a pedir,..." (Carla)

“... o mini grupo está descobrindo o mundo de poder contar as coisas, passar para a gente tudo. Até da casa deles eles, o que a mãe faz, o que deixa de fazer e a segurança que eles têm, eles vêem na gente um amigo, né. Eles passam mesmo, tudo, tudo. Tudo o que acontece em casa, principalmente às segundasfeiras.... Eles têm um monte de coisas para falarem." (Maria)

"Com eles é normal estarem trocando, né? (...)a criança fica trocando, fica falando errado quando pequena, fala /fassora/, troca o / $/$ pelo /f/, a gente fica até achando bonitinho, porque é uma linguagem de bebê... (...) Mas quando é alguma coisa que eu acho fácil e eles estão falando errado ai a gente dá uma corrigida, mas normalmente eu não fico pegando muito no pé do que eles falam porque eu acho eles pequenos ainda." (Carla)

"... Olha, a comunicação deles assim, pra mim, quando eles querem alguma coisa mais de mim, eles me agradam, me abraçam, me beijam, e pedem assim... "Ah, Tia D., dá prá mim, por favor?" Sabe, aquela coisa assim, sabe para me chamar a atenção mesmo..." (Anita)

As caracteristicas da linguagem oral presentes nas crianças do matemal I (crianças de 3 a 4 anos) foram evidenciadas pelas ADI quando identificam o uso de um vocabulário mais abrangente.

Neste período da vida as crianças deixam transparecer pela sua fala a sua capacidade simbólica no momento em que representam papéis e constroem estórias imaginárias. Ao brincarem as crianças interagem coordenando seus papéis e criando situações imaginárias nas quais assumem outros papéis para os explorar melhor. 
"Eles conversam. Têm alguns que fazem um tipo de carinho. Hoje mesmo, a J. estava chorando, a outra foi lá, deitou ela no colo, a cabecinha dela no colo e ficou: “Não chora não J., ela é feia." Ela tinha brigado com outra criança. Dai daqui a pouquinho mesmo essas duas estavam brigando. Eles conversam e ao mesmo tempo que eles brigam por algum brinquedo, estão agradando um ao outro, e conversam entre eles. (...)Eles fazem a mesma coisa, uma xerox da gente, o que a gente está fazendo, daqui a pouquinho eles estão fazendo igual. A tarde é a C. (ADI do turno da tarde) e às vezes eu náo consigo passar para ela e não tem problema porque eu tenho a J. que conta tudo para a colega ADI, para quem eu dei banho, porque eu dei banho,... (...) Entăo entre eles, eles conversam bastante, trocam idéias sim, conversam sim, falam de papai, mamáe, bonecas, tratam as bonecas, eu acho que eles vêem as mães em casa, banho, tudo. E sempre em grupinho nunca estăo sozinhos!" (Maria)

“Conversam, pedem, brigam, um quer água, eu já percebi um pedindo para eu dar água para o outro, um quer ir ao banheiro, aí um fala "Eu vou falar para a tia", é assim, a fala é comum entre eles, normal!" (Joana)

As ADI deixam transparecer que a comunicação oral é uma constante no convivio diário ao se referirem às crianças de 4 a 5 anos de idade do maternal II.

A linguagem oral é um aspecto do desenvolvimento das crianças observado e valorizado pelas $A D I$ na realização das suas atividades junto às crianças.

"As crianças do maternal II, de 4 a 5 anos têm necessidade de falar, eu acredito que eles estão naqueles momentos de estarem vendo as coisas, querendo saber. Então tem aquela necessidade de informação. Eles pedem e nós temos necessidade de passar também. Com a mesma rapidez que eles querem saber, eles 
ficam olhando, eu acho isso também. A impressão que dá é que vêm as informaçōes e já tem que sair logo, ao contrário do adulto, que tem muitas informaçōes, a gente guarda..." (Marlene)

"Eu observo que essa idade é uma idade em que eles conversam muito, muito, muito. Conversam bastante. Só ficam quietinhos quando eu falo, assim é o nosso trato, para levantar a måo... (...) ... sou uma tia que eles gostam de mim, eles năo tếm receio, medo ou vergonha de falar comigo. Entăo tudo eles conversam. Eles conversam normalmente comigo. E eu normalmente com eles. Não tenho problema de contato." (Joana)

"Nossa! Se deixar, vocé nem fala, vocé viu naquela vez... Se vocé deixar eles nem dão tempo para você. Você tem que pedir para eles pararem, fazer a gentileza de pararem de falar, para fazer uma atividade se não..." (Paula)

“... Falam bastante, conversam normal mesmo, assim, como se fossem adultos (...) ... aquela criança que fala mais acaba até se destacando mais do que os outros. E conseguindo mais, dominando até a fala. Por isso acho a fala muito importante nessa idade. Aqueles que ficam mais no sinal, no toque, apontando, quase que não são percebidos na sala..." (Neiva)

“... sou como o pessoalzinho de 5 anos, eu gosto de estar falando, embora Iógico, com o cuidado de saber o que eu vou passar e o que eu vou guardar, mas eu gosto muito de conversar. Eu tenho muita facilidade com eles, como na estória, eu năo consigo contar uma estória sem acrescentar um monte de coisa, eles ajudam... (...) A gente fala de muita coisa. (...) Tem uma coisa também, eu acho muita graça, tem hora que tem que segurar, dá aquela vontade de rir gostoso, sabe quando a gente está bem a vontade, eles falam alguma coisa ou agem de uma certa maneira." (Marlene) 
"Me interessa observar as crianças conversando. Eu gosto. Gosto de ouvir elas falando. Mas quando começa a conversar mesmo, a gente percebe que ela conhece bastante coisa..." (Neiva)

Novamente encontramos nas seguintes falas das $A D I$ referências aos fatores facilitadores do desenvolvimento da linguagem oral. tais como, a afetividade. o estímulo dos pais e das pessoas que convivem com a criança, a interação com as outras pessoas e as condições de saúde em geral da própria criança.

"A criança tem que gostar, tem que gostar, e ela gostou, fica tudo mais fácil. A fala também, porque ela confia, ela não fica receosa, ela pōe para fora, eu penso desse jeito. (...)Eu acho que se ela confia, tem carinho, ela dialoga, ela conversa, ela põe em prática." (Joana)

"Ah, agora eu acho que é assim, o estimulo dos pais, a convivência da criança no dia-a-dia... Se existe harmonia dentro de casa que ajuda a estimular a criança também, eu acho que ajuda bastante. Agora na própria criança eu acho que se é uma criança saudável, uma criança perfeita, se tem tudo isso daí eu acho que não tem nada que impeça ela de falar." (Dana)

"Estimular a criança a falar é falar com ela, é colocá-la junto naquele momento. Porque muitas vezes, já falei, a criança... começa falar e ai o que a gente pede, vamos incentivar, vamos estar estimulando com allbum de gravuras, livro, estórias, através de relacionar uma coisa a outra, é uma forma de estar ajudando, estimulando. Estimular acho que é,... pondo para ela uma condição, um ambiente, criar uma situação onde ela venha a desenvolver mais ainda. É criar situações, incentivar. Pode-se criar várias coisas para isso, é contar uma estória, cantar, contato 
com livros, revistas, levá-los para lugares, sei lá, eu acho que isso esta estimulando. Estar falando, falando." (Marlene)

"Atividades para desenvolver a fala é mais isso mesmo: revistas, livros, é o contar estórias, deixá-los contar,... (...) As outras atividades indiretamente estão desenvolvendo a fala, se eu vou explicar alguma coisa de matemática para eles, eu vou estar falando com eles, vou estar esperando que eles me retornem alguma palavra." (Maria)

Depreendemos das falas das ADI a percepção de que desempenham um papel importante no desenvolvimento da linguagem oral.

$\mathrm{Na}$ medida em que estruturam atividades que proporcionam experiências para a exploração ativa das crianças, dão atenção, ouvem, mantêm contato de olho, dialogam, suprem as necessidades, orientam e compartilham vivências.

“Nos tornamos facilitadoras, olha, eu acho que todo o momento. O momento todo. Durante a hora que a criança tá aqui, o momento todo nós nos tomamos facilitadoras dessas crianças no trabalho. Acho que é no dia-a-dia, todos os dias da segunda a sexta." (Beatriz)

"Eu participo de todas as atividades,... tenho que passar a toda hora "Tia". Tenho que ir lá. "Tia, venha ver, é assim?" "Tia está bonito? Pintei as orelhas, tá bonito?" "O meu é mais bonito?" Então não há meio de colocá-los na mesa e sentar. Porque eles exigem muito, toda a hora tem que estar passando, falando, conversando,..." (Joana) 
"Em todas as atividades a ADI é importante. Porque a gente conversa, pergunta, eles também perguntam, é de muita importáncia. Não tem como deixá-los fazer, sair, não tem como. Tem que estar presente, dando orientação." (Carla)

"Se eu falar que a presença da ADI não é necessária, eu acho que não tem como ser. Porque eles náo sabem tomar banho, lavar o corpo, passar o sabonete, ...Se eu não ficasse junto, eles não tomariam banho assim, não escovariam os dentes como tem que escovar..." (Paula)

"Ah! Acho que nós temos que tentar incentiválos. Crejo que seja isso, né? Assim, por exemplo, tentar levar a criança a fala /titial, mas tem que ensinar direito, né? Evitar que a criança fique chupando chupeta, né? Acho também que a chupeta prejudica a fala..." (Ana)

"Quando você vai cantar, né, canta uma musiquinha com a criança. Vocé percebe que a criança já começa a bater palmas e às vezes elas nảo falam a palavra toda, mas já repetem as últimas que você fala, por exemplo, "Atirei o pau no gatótô!" elas repetem o /tôtó, entáo quer dizer no que eu estou falando elas estão aprendendo!" (Dana)

"Eu tento ficar junto, trabalhando, fazendo trabalhos com eles. Junto , fazendo junto com eles, cantando com eles (...) Sempre que eu estou participando junto, eles participam mais. Quando eu sento em roda nas cadeiras, mesmo no chão, eles mesmos interagem mais com a gente, adulto, e com eles mesmos." (Tânia)

“... Mas vocé ter carinho para a criança, amor, respeito pela aquela criança, também tem que respeitar a criança, né? Acho que se você fazer tudo isso, você consegue fazer o desenvolvimento da criança, sabe, na fala, em tudo, a criança fica esperta, inteligente, sabe, e a presença da tia é muito importante, creio eu que sim. 
Que seria de nós sem as crianças, o que seria das crianças sem as tias, né? A creche é uma coisa muito importante pras crianças, né?" (Ana)

"É muito gratificante saber que você está sendo importante na evoluçăo (promoção) de uma criança, de uma pessoa, de um adulto de amanhã." (Rose)

Temos a considerar que o momento do aparecimento da linguagem oral $\dot{e}$ considerado como um marco fundamental tanto para os pais, familiares como para as ADI no cotidiano de suas relações com as crianças.

Sendo assim, reiteramos que em situações de interações de crianças, a importância do adulto também está presente, na medida em que a fala do adulto está inserida na linguagem da criança, ou seja, a fala da criança é construida a partir da relação com o adulto.

O adulto ao interpretar a ação da criança, abre a possibilidade de ela interpretar fragmentos do discurso, já que a criança ocupa seu turno no diálogo com o adulto, estando dessa forma, presente na linguagem do outro. Cabe ao adulto, portanto, o papel de facilitador já que conhece o conjunto de regras lingüisticas de uma comunidade partilhar este conhecimento com as crianças, interpretando o que estas expressam (comportamentos verbais e não verbais) (LIER. 1983; RUBIANO. 1990; ARANTES, 1994).

Concluindo, as crianças a partir das interpretações do adulto são capazes de construirem um conhecimento sobre a linguagem e o mundo em que vivem. 
3.2.5. A linguagem oral enquanto expressão do desenvolvimento da criança

Quando incentivadas a falarem sobre o momento do aparecimento da linguagem oral na criança, reconhecemos que para as entrevistadas é um momento do desenvolvimento observado e valorizado.

As ADI falam com emoção, com grande satisfação e pontuam uma evidente gratificação. na medida em que pensam que a linguagem expressa pela criança pode ser considerada como indicadora da sensibilidade e interação da criança com as pessoas com as quais convive. Como se as $A D I$ pela primeira vez, obtivessem informações precisas sobre aquilo que a criança sabe e pensa.

Podemos considerar como se a linguagem das crianças fomecesse uma "janela" através da qual, as ADI pudessem "olhar" para o interior das crianças assistidas.

Observamos os seguintes depoimentos:

“... Eu sei que foi uma emoção grande (choramingando) quando ela falou a 1" palavrinha." (Tânia)

"Pra mim é muito gratificantel Eu me sinto ótima quando eles começam a falar alguma coisinha. (...) eu sempre converso tudo. Falo para eles assim "Vem com a titia!" "Vamos papa??" "Vem com a titia." "Vamos tomar banho?" Ai eles começam a pronunciar alguma coisa. Quando ela começou a falar. A primeira palavra que ela disse foi /mãel. Então eu falei para ela "B. eu não sou sua mamãe eu sou sua tia!" "Titia, não mamãe!" Passou alguns dias e ela me chamou de mamãe. Passou outros dias e ela me chamou de mãe. Falei que eu era a titia e não a mamãe. Foi quando um dia ela começou a brincar "Ti..., titi, titiaaaa!" Eu fiquei... eu né adoro! Fiquei muito 
emocionada. Eu adoro quando eles me chamam. (...) Prá eles (crianças) também é muito gratificante... (...) ...ela está conseguindo se expressar . Se ela falou aquilo e você entendeu, para ela é gratificante! E ela está conseguindo se expressar: "Papá" o que ela está querendo? o que está pedindo? Ela está conseguindo passar para a gente. (...) Quando a pessoa entende o que a criança quer, por exemplo eu, ela se sente gratificada, sente-se bem, porque vocé está entendendo o que ela quer. (...) $E$ gratificante e ela começa a falar mais, mais, mais, mais. Porque eles falam! Quando eles começam a falar, falam. Nossa!" (Rose)

"O balbucio, o falar, significou bastante para mim, ... Quando eu entrei aqui, eu entrei com muito afinco, com muita ânsia de cuidar de tudo, então para mim foi como se fossem meus filhos! Foi bastante importante ouvi-los balbuciarem a primeira palavrinha ou /tial, foi bastante mesmol (...) Através da fala eles passam para a gente o que eles estão sentindo, o que estão querendo... (...)quando são bebês e choram você coloca a chupeta na boca, mas năo é a chupeta que eles querem, eles estăo com fome. As vezes você dá comida e eles estão é com uma dor. E não podem falar, de repente começam a falar "Ai, que alivio, agora eu posso falar o que estou sentido, se estou chorando năo é chupeta que quero,..." (Maria)

“... eles estão se comunicando, né. Está passando aquilo que eles pensam, eles usam o vocabulário para dizer o que eles querem mesmo, o que sentem. Eles são, como se fala, eles falam o que eles querem, não como a gente que quer falar alguma coisa e fala outra. Eles já falam o que estăo sentindo. (...) ... se eles não falarem como eu vou saber que eles estão sentindo dificuldade, como vou saber que eles querem alguma coisa a mais daquilo que eu estou passando, como vou saber que eles estão sentindo alguma coisa, uma dor, algum machucado,..." (Paula)

Ao servirem-se das palavras, as crianças aprendem o que é o mundo que as rodeia e como se comportam as pessoas nele. 
A criança ao descobrir a linguagem estabelece relações entre os sons e aquilo que consegue compreender sobre a natureza das coisas que o rodeiam.

"Eu acho que ela vai descobrindo, descobrindo as coisas, né? Descobrindo cada vez mais coisas. Através da fala..." (Tânia)

"É descobrir, acho que ela vai descobrir tudo, se a criança náo fala ela fica no mundo dela mesmo. Se ela começa a falar, ela começa a expor sentimentos, começa a poder pedir as suas necessidades. (...)Eu acho que elas vêem o mundo mais fácil até para elas também. (...) É interessante quando ela (a criança) começa a falar, ela começa a ter mais independência também. "Quero água" "Estou com fome"." (Joana)

“... A fala da criança é tudo. Uma criança sem fala, ela vive num mundo apagado. Pra mim él" (Ana)

"Quando a criança começa a falar significa que a criança está se desenvolvendo bem, e que a gente está também atenta ao desenvolvimento da criança!" (Carla)

Os depoimentos apresentados evidenciam que não somente para o adulto 0 surgimento da fala é importante mas também para a própria criança.

Para algumas $A D I$ a linguagem oral pode ser considerada como reveladora do crescimento e desenvolvimento das crianças. 
"Linguagem, acho que é comunicação escrita e na falada. Eu acho... (pausa longa) Linguagem pode ser oral, a pessoa chega e fala, conversa. Pode ser mesmo lida, escrever alguma coisa. Dos dois jeitos estão se comunicando." (Neiva)

“Mesmo na idade de 2 anos, a linguagem oral para mim é isso estar se encantando com as palavras soltas. É falar o certo." (Maria)

“... serve pra tudo, sem fala a gente não abre caminho pra nada. A fala é a vida!" (Ana)

“Na própria criança, ele está descobrindo, né? Eu acho que ele está descobrindo coisas, descobrindo o mundo, ele tá descobrindo as coisas que ele vê, entăo ele se expressa no falar, né? Eu vejo assim, ele tá se descobrindo, começa a falar e está se descobrindo. Se falar, eu vejo assim". (Beatriz)

"Linguagem é a forma que você tem de usar as suas palavras e de falar e também de escutar." (Paula)

À medida que a criança interage com o seu meio. ampliando seus recursos de linguagem e de coordenação de suas ações o seu pensamento torna-se mais complexo.

"É importante falar, é o seu jeito de expressar a idéia, conversar, falar mesmo que esteja errado. É importante a fala!" (Anita)

"É importante a fala. Tanto para a criança quanto para o adulto." (...)É um meio de comunicação, quanto mais você fala mais você vai entendendo, né?" (Ivete) 
"A fala serve para se comunicar, para se comunicar, para expressar, expressar tudo, raiva, amor, vontades, o que quer o que não quer, tudo, é muito importante!" (Carla)

Concluindo, o desenvolvimento da linguagem oral permite à criança formular suas questōes sobre a realidade presente e ausente, estabelecer e modificar as suas relações, transformar as suas circunstâncias e enriquecer as suas vivências e experiências.

"O espírito da criança é terno, sua carne é delicada: o sol, a lua, a chuva, o vento, o silêncio, tudo isto cai sobre ela. A criança absorve insaciavelmente o mundo, o recebe em suas entranhas, o assimila e o transforma em criança".

Nikos Kazantzakis 
Anexo 7: Carta de apresentação da pesquisadora à coordenadora das creches 

de de 1998

Prezada Senhora,

Cumprimentando-Ihe, apresento-me como fonoaudióloga, aluna do Curso de PósGraduação em nível de Doutorado, do Departamento de Saúde Materno-Infantil da Faculdade de Saúde Pública da USP. sob a orientação do Prof. Dr. Cornélio Pedroso Rosenburg. A área do conhecimento que estudo e desenvolvo no momento é o desenvolvimento da linguagem oral em crianças no contexto de uma creche.

Pessoalmente, acompanhar o desenvolvimento da linguagem oral em crianças institucionalizadas é um desafio, uma prazerosa atividade e um grande contentamento. Com o desenvolvimento, o desabrochar da linguagem oral na criança, torna-se um dos elementos fundamental reguladores da interação, na medida que constitui o substrato necessário à representação e à troca de mensagens. Acrescento ao adulto uma responsabilidade como "participante-facilitador" do processo de desenvolvimento da linguagem oral na criança.

Gostaria de desenvolver uma pesquisa na creche Cadi $34 \mathrm{Jd}$ Elisa Maria, situada a Rua Rômulo Naldi, 137 no Jd Elisa Maria, vinculado a essa importante Secretaria. Para tanto, apresento sucintamente as intenções desse estudo: entrevistar as auxiliares de desenvolvimento infantil: identificar por meio de seus discursos o que pensam sobre o desenvolvimento da linguagem oral; observar o seu cotidiano e descrever a linguagem de crianças do maternal II com tempos diversos de acompanhamento nesta creche.

Assim. venho solicitar seu consentimento à realização deste estudo.

Agradeço antecipadamente seu parecer, desejando participar a essa Secretaria os resultados e reflexões desse trabalho.

\section{Sinceramente}

Fga Andrea Wander Bonamigo

llma Sr"

Dolores Aparecida da Silva Novais

Diretora da Macro Capital e Coordenadora dos CADI's

Secretaria de Assistência e Desenvolvimento Social - Estado de São Paulo 
Anexo 8: Convite aos responsáveis pelas crianças selecionadas a participarem da pesquisa 
São Paulo. de de 1999

Senhores pais e/ou Responsáveis:

Estamos realizando uma pesquisa cientifica neste CADI que tem como tema "O desenvolvimento da linguagem oral em crianças no contexto de uma creche" $\mathrm{e}$ como parte integrante desse estudo necessitamos realizar a descrição da linguagem de seu(sua) filho(a). Este procedimento será realizado nas dependências da própria creche pela fonoaudióloga responsável.

Solicitamos a sua concordância por escrito quanto à participação de seu/sua filho (a) nas filmagens do cotidiano. tendo ciência que será garantido o sigilo e o anonimato dos resultados e que a qualquer momento a decisão de abandonar o estudo possa ser tomada pelos responsáveis.

Responsável:

Atenciosamente,

$\mathrm{Fg}^{\mathrm{a}}$ Andrea Wander Bonamigo 
Anexo 9: Instrumento para a descrição da linguagem oral 


\section{Instrumento para a Descrição da Linguagem Oral}

O instrumento utilizado para as finalidades desta pesquisa está constituido por três partes, Formação de Conceitos. Desenvolvimento Fonêmico e Narrativas Orais.

Parte I - Formação de Conceitos (Funções Básicas da Linguagem, Aspectos Cognitivos da Linguagem)

Esta primeira parte do instrumento, objetiva evidenciar a nomeação, seriação, classificação e a compreensão de elementos que portam noçãos considerados essenciais para o desenvolvimento da linguagem, tais como: esquema corporal, espaço, tamanho, distância, quantidade. forma. espessura, altura, comprimento, igual-diferente. seqüència lógica-temporal e cor.

Exemplificando, observando as crianças em contextos de brincadeira, contar estórias, solicitar:

- Mostre para mim que cor é essa (apontando para a cartela de cores) e/ou objeto concreto. - Qual é a bola que está mais próxima à árvore? (observando a figura).

\section{Parte II - Desenvolvimento Fonêmico}

Esta estratégia de investigação tem por objetivo descrever as generalizações do sistema fonêmico das crianças e reconhecer as caracteristicas de produção da fala.

As crianças foram estimuladas a nomearem seres, ações e a construirem estórias por meio da observação de cinco desenhos temáticos, a saber, veiculos, sala, banheiro, cozinha e zoológico.

\section{Parte III - Narrativas Orais}

Este item tem por objetivo verificar e descrever o desempenho das crianças na elaboração de narrativas orais quanto as seguintes aspectos, estruturação da narrativa, coesão, coerência, propriedades semânticas, morfossintáticas e pragmáticas em duas circunstâncias, por meio da observação de estímulos visuais em seqüência e desenhos temáticos, e de manifestações orais espontâneas 


\section{Protocolo de registro dos achados da descrição da linguagem oral}

\section{DESCRIÇÃO DA LINGUAGEM ORAL}

\section{PARTE I - FORMAÇÃO DE CONCEITOS (FUNÇÕES BÁSICAS DA LINGUAGEM)}

\section{TEMA 1. COR (Identificação e nomeação)}
1.1. vermelho
[ noção presente
noção ausente
1.2. azul
noção presente
noção ausente
1.3. verde
noção presente
noção ausente
1.4. amarelo
noção presente
noção ausente
1.5. preto
noção presente
noção ausente
1.6. branco
noção presente
noção ausente
1.7. roxo
noção presente
noção ausente
1.8. Iaranja
noção presente
noção ausente
1.9. marrom
noção presente
noção ausente

TEMA 2 - FORMA (Identificação e nomeação)
2.1. quadrado
I noção presente
2.2. circulo
2.3. triângulo
noção presente
$\square$ noção ausente
noção presente
noção presente
noção ausente
noção ausente
noção ausente

TEMA 3 - ESQUEMA CORPORAL (Identificação e nomeação das partes do corpo)
3.1. cabeça
noção presente
noção ausente
3.2. cabelo
noção presente
noção ausente
3.3. olhos
noção presente
noção ausente
3.4. nariz
noção presente
noção ausente
3.5. boca
noção presente
noção ausente
3.6. lingua
noção presente
noção ausente
3.7. dente
noção presente
noção ausente
3.8. lábio
noção presente
noção ausente
3.9. bochecha
noção presente
noção ausente
3.10. pescoço
noção presente
noção ausente
noção presente
noção ausente
noção presente
3.12. mão
noção presente
noção ausente
noção ausente
noção presente
noção ausente
noção presente
noção ausente
3.15. barriga
noção presente
noção ausente
3.16. perna
3.17. pé
3.18. cotovelo
noção presente
noção presente
3.19. joelho
3.20. tomozelo
noção presente
noção ausente
noção ausente
noção ausente
noção ausente
3.21. calcanhar
noção presente
noção ausente
3.22. costas
noção presente
noção ausente 
TEMA 4 - ESPAÇO

4.1 em cima

4.2 embaixo

4.3 dentro

4.4 fora

4.5 atrás

4.6 frente

4.7 lado noção presente

noção presente

noção presente

noção presente

noção presente

noção presente

noção presente noção ausente

noção ausente

noção ausente

noção ausente

noção ausente

noção ausente

noção ausente

TEMA 5 - TAMANHO

5.1. menor

5.2. maior

noção presente

= noção ausente

5.3. pequeno

5.4. médio

noção presente

- noção ausente

- noção ausente

- noção ausente

5.5. grande

noção presente

noção presente

noção ausente

TEMA 6 - DISTÂNCIA

6.1. longe

- noção presente

- noção ausente

6.2. perto

noção presente

= noção ausente

TEMA 7 - QUANTIDADE

7.1. mais

noção presente

I noção ausente

7.2. menos

noção presente

$\square$ noção ausente

7.3. muito

noção presente

$\square$ noção ausente

7.4. pouco

noção presente

D noção ausente

TEMA 8 - ESPESSURA

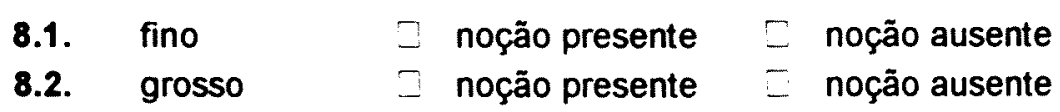

TEMA 9 - ALTURA

9.1. alto

- noção presente

noção ausente

9.2. baixo

noção presente

noção ausente

\section{TEMA 10 - COMPRIMENTO}

10.1. curto $\quad$ noção presente

10.2. comprido $\square$ noção presente $\square$ noção ausente

\section{TEMA 11 - IGUALIDIFERENTE}

11.1. igual

noção presente

noção ausente

11.2. diferente

noção presente

noção ausente

TEMA 12 - SEQÜÊNCIA LÓGICO-TEMPORAL

12.1. ordenação 3 figuras

noção presente

noção ausente

12.2. ordenação 4 figuras

noção presente

noção ausente 
PARTE II - DESENVOLVIMENTO FONÊMICO

TEMA 13 - DESCRIÇÃO FONÊMICA

13.1. inventário fonológico

13.2. inventário fonético

13.3. Sons consonantais

13.4. Sons vocálicos

13.5. produção de semivogais

13.6. realização de arquifonemas

13.7. realização de grupos consonantais

13.8. traços distintivos

$\begin{array}{lll}\text { completo } & \square & \text { incompleto } \\ \text { completo } & \square & \text { incompleto } \\ \text { presentes } & \square & \text { ausentes } \\ \text { presentes } & \square & \text { ausentes } \\ \text { presente } & \square & \text { ausente } \\ \text { presente } & \square & \text { ausente } \\ \text { presente } & \square & \text { ausente } \\ \text { presentes } & \square & \text { ausentes }\end{array}$

TEMA 14 - CARACTERÍSTICAS DE PRODUÇÃO DA FALA

14.1. Ausência de hábitos orais viciosos

14.2. Tonicidade e mobilidade dos $\mathrm{OFA}^{1} \mathrm{em}$ movimentos isolados

14.3. Posição dos OFA na articulação

14.4. Habilidade perceptual na organização dos fonemas

14.5. Habilidade motora em seqüência para a articulação dos fonemas
$\square \operatorname{sim} \square$ não
$\square$ adequadas $\square$ inadequadas
$\checkmark$ adequada $\Sigma$ inadequada
$\square$ presente $\square$ ausente
presente $\square$ ausente
$\square$ inteligivel $\square$ ininteligivel

14.6. Fala espontânea

${ }^{1}$ OFA $\rightarrow$ órgãos fonoarticulatórios

Obs.: Compreensão de contextos de fala:

\section{PARTE III - PRODUÇÃO DE NARRATIVAS ORAIS}

TEMA 15. NARRATIVAS ORAIS

15.1. estrutura da narrativa

15.2. marcadores conversacionais

15.3. tomada de turnos do diálogo

15.4. estabelecimento de relaçōes temporais

15.5. estabelecimento de relações causais

15.6. compatibilidade entre a ordenação de figuras e o relato

15.7. eliciação da narrativa pela criança

15.8. uso de operadores da narrativa

15.9. introdução de personagens

15.10. construção do interlocutor

15.11. criança como sujeito da enunciação

15.12. incorporação de fatos vivenciados pela criança

15.13. elementos de coesão

15.14. elementos de coerência
presente
presentes
presente
presente
presente
ausente
ausentes
ausente
ausente
ausente
presente $\square$ ausente
presente $\quad$ ausente
presente $\square$ ausente
presente $\square$ ausente
presente $\square$ ausente
presente $\quad$ ausente
presente $=$ ausente
presentes - ausentes
presentes ... ausentes 
100-A

15.15. propriedades semânticas

15.16. propriedades morfossintáticas

15.17. propriedades pragmáticas

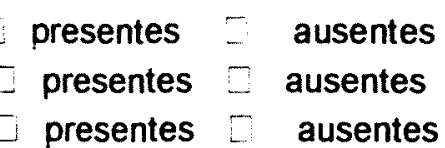


Anexo 10: Figuras integrantes das estratégias utilizadas para a descrição da linguagem oral 

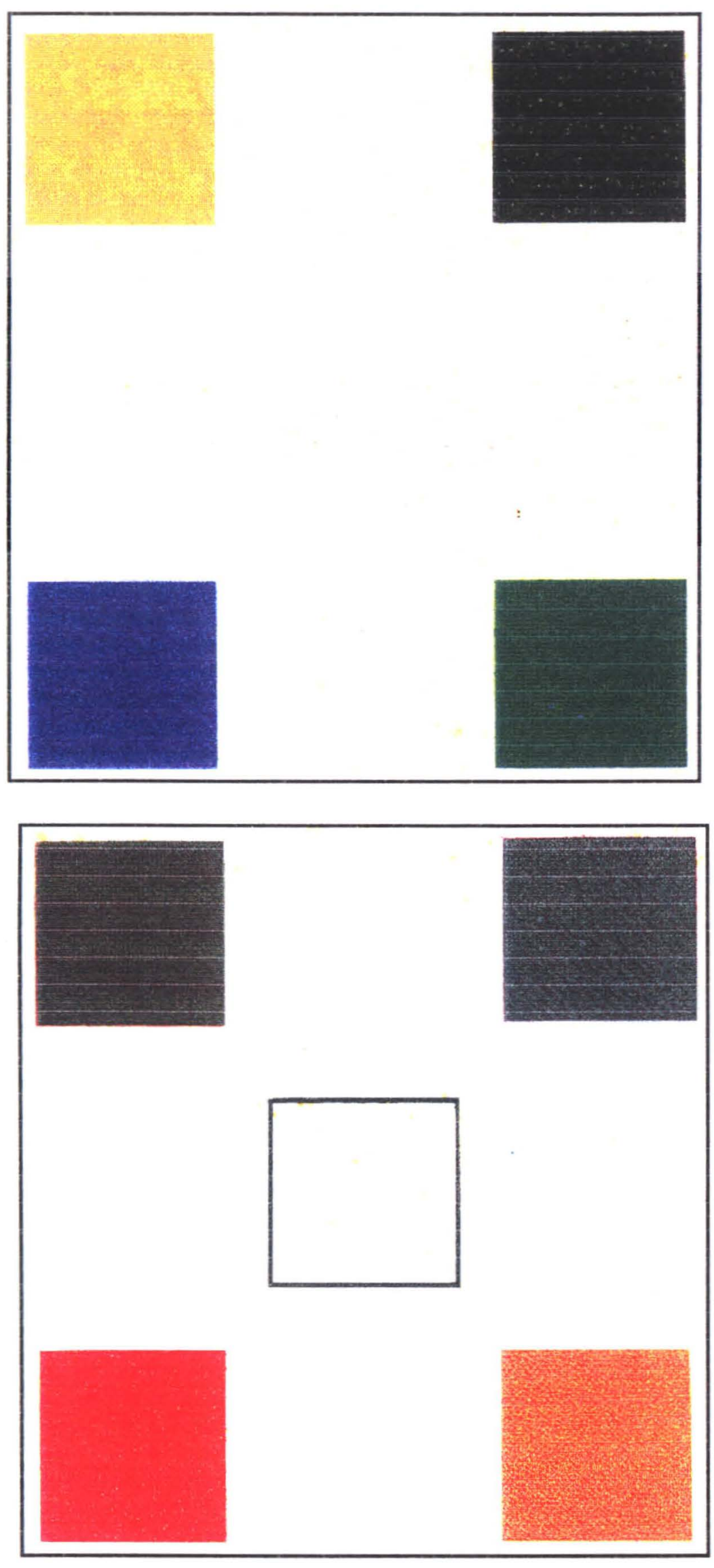

Biblioteca/CIR

FACULDADE DE SAÚDE PÚBLICA

UNIVERSIDADE DE SAO PAULOO 
103-A
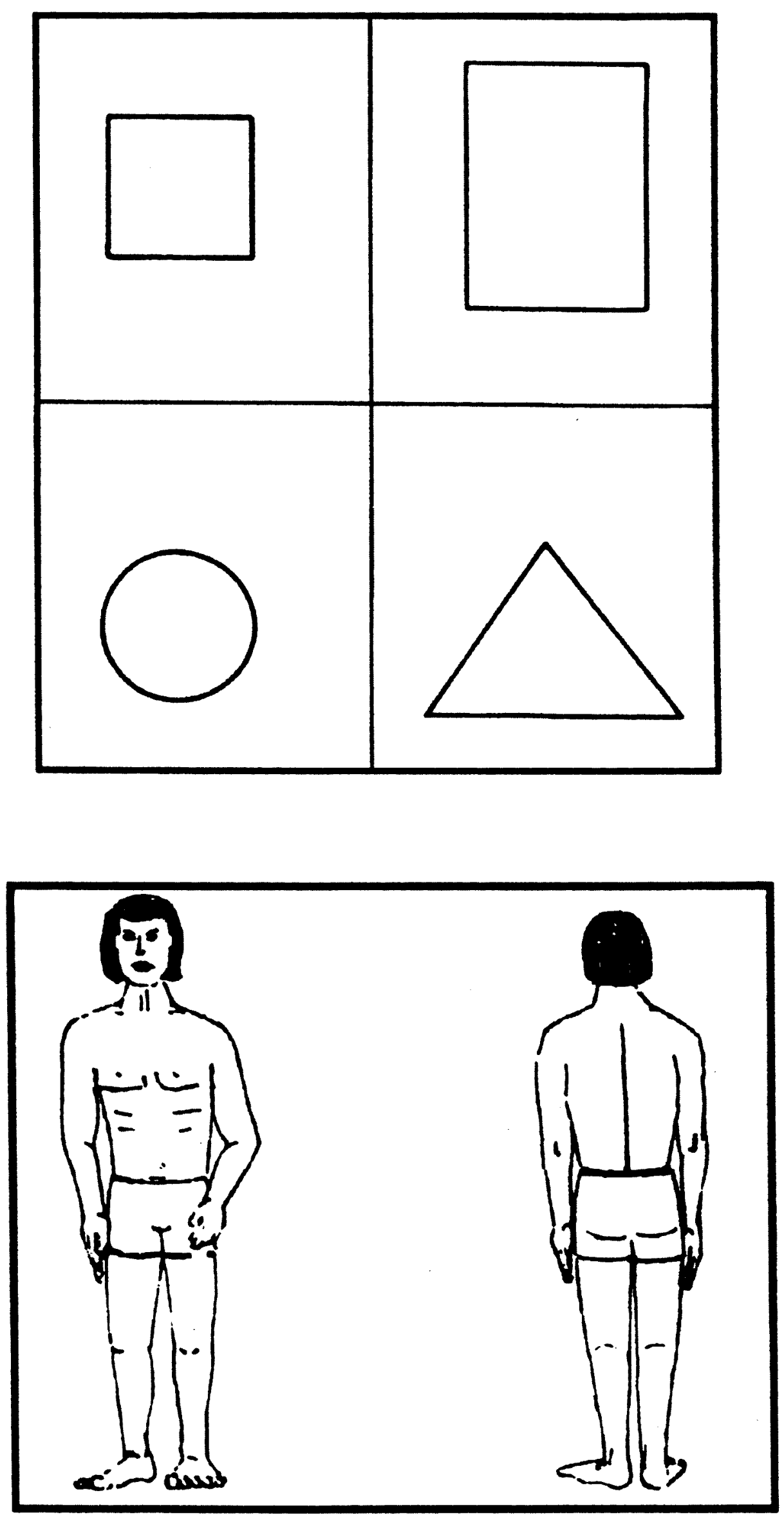

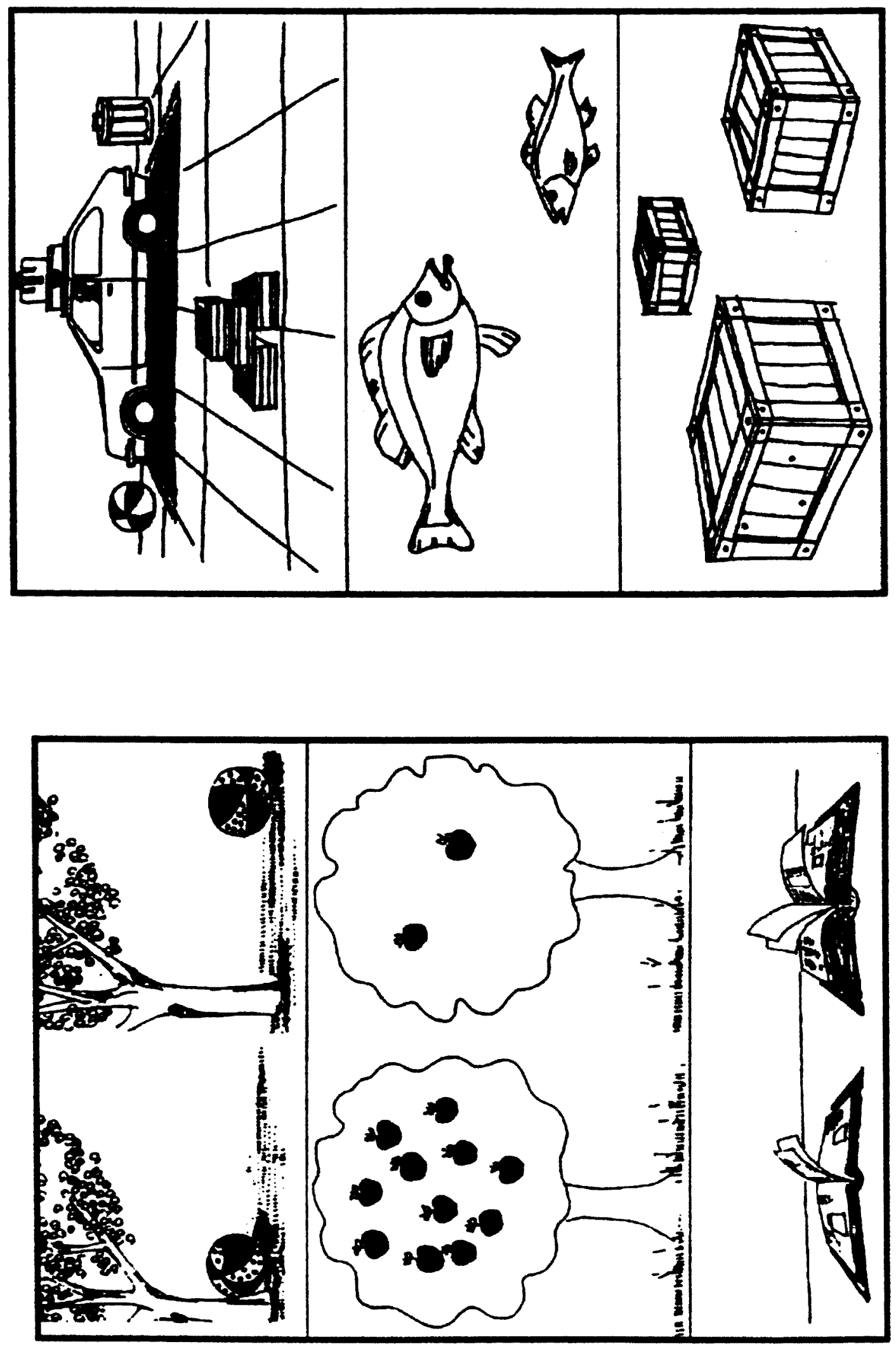

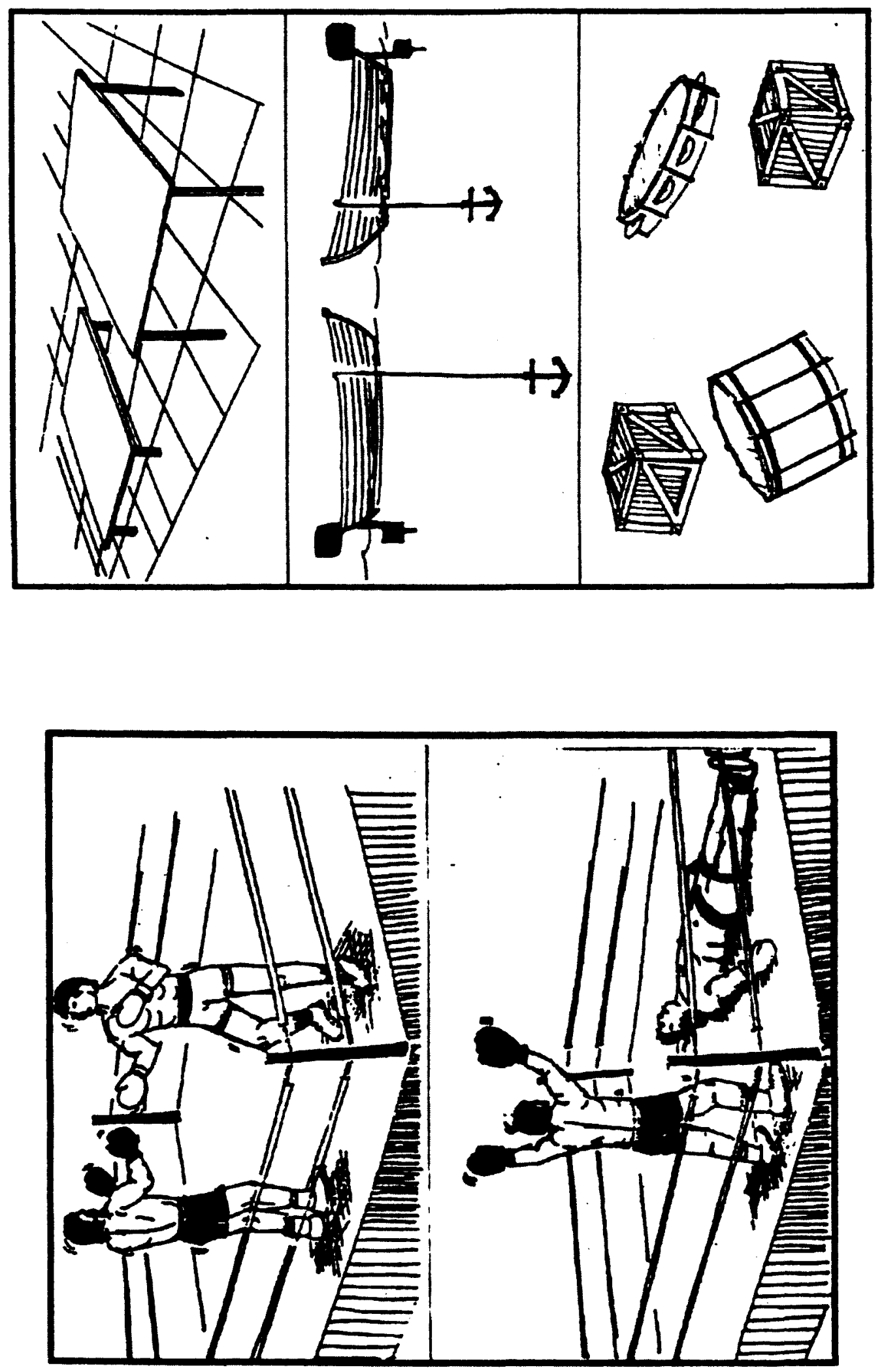


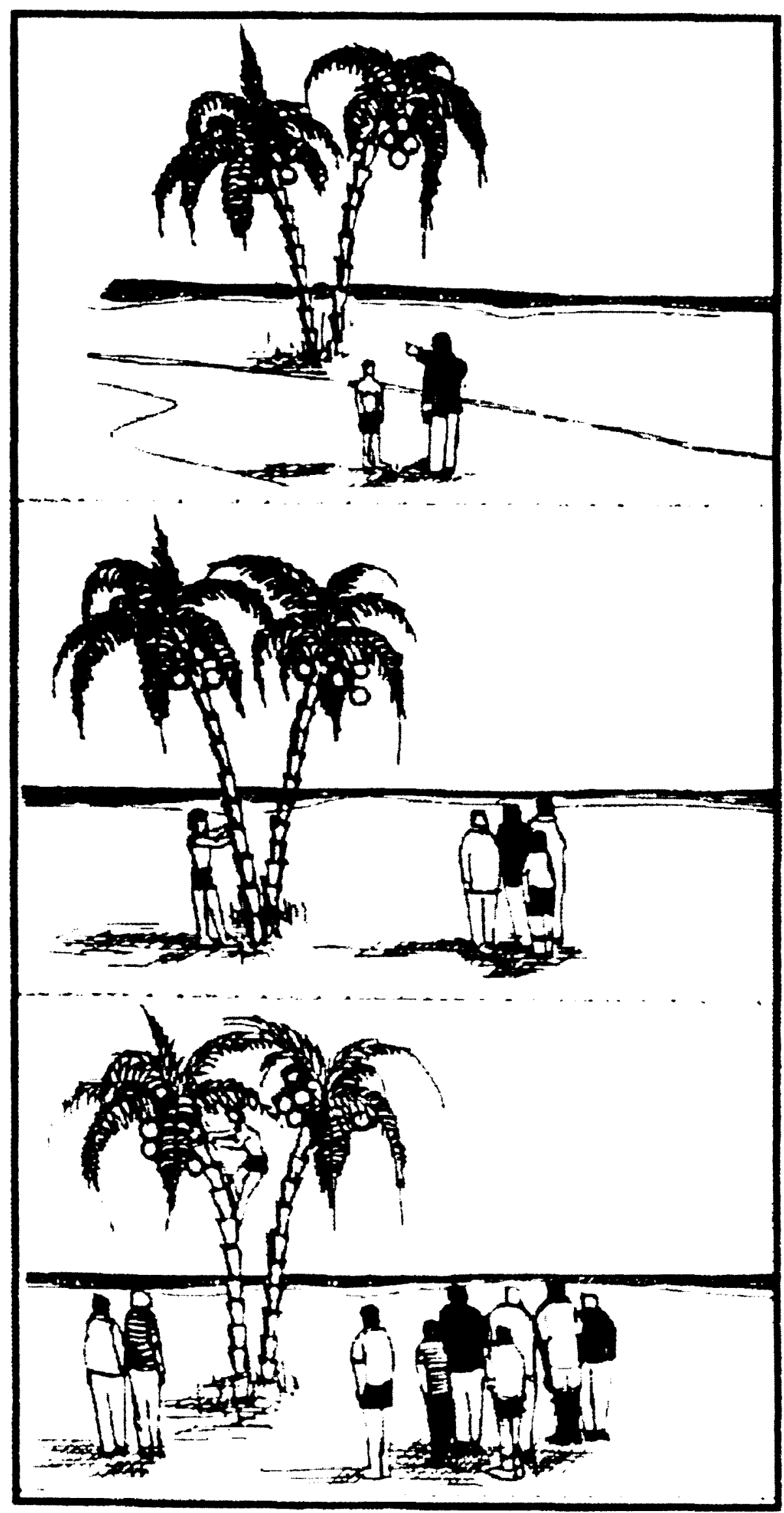




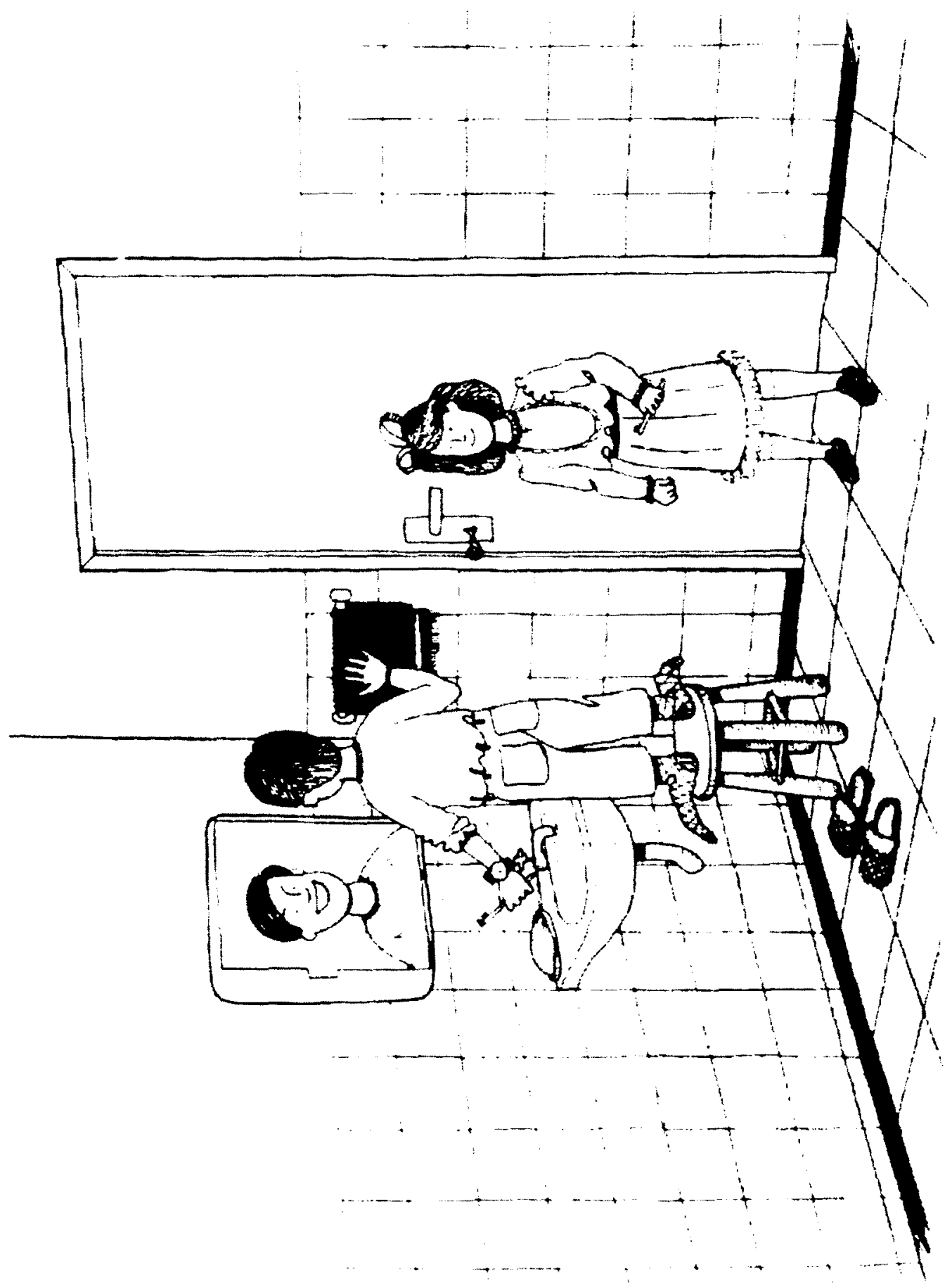




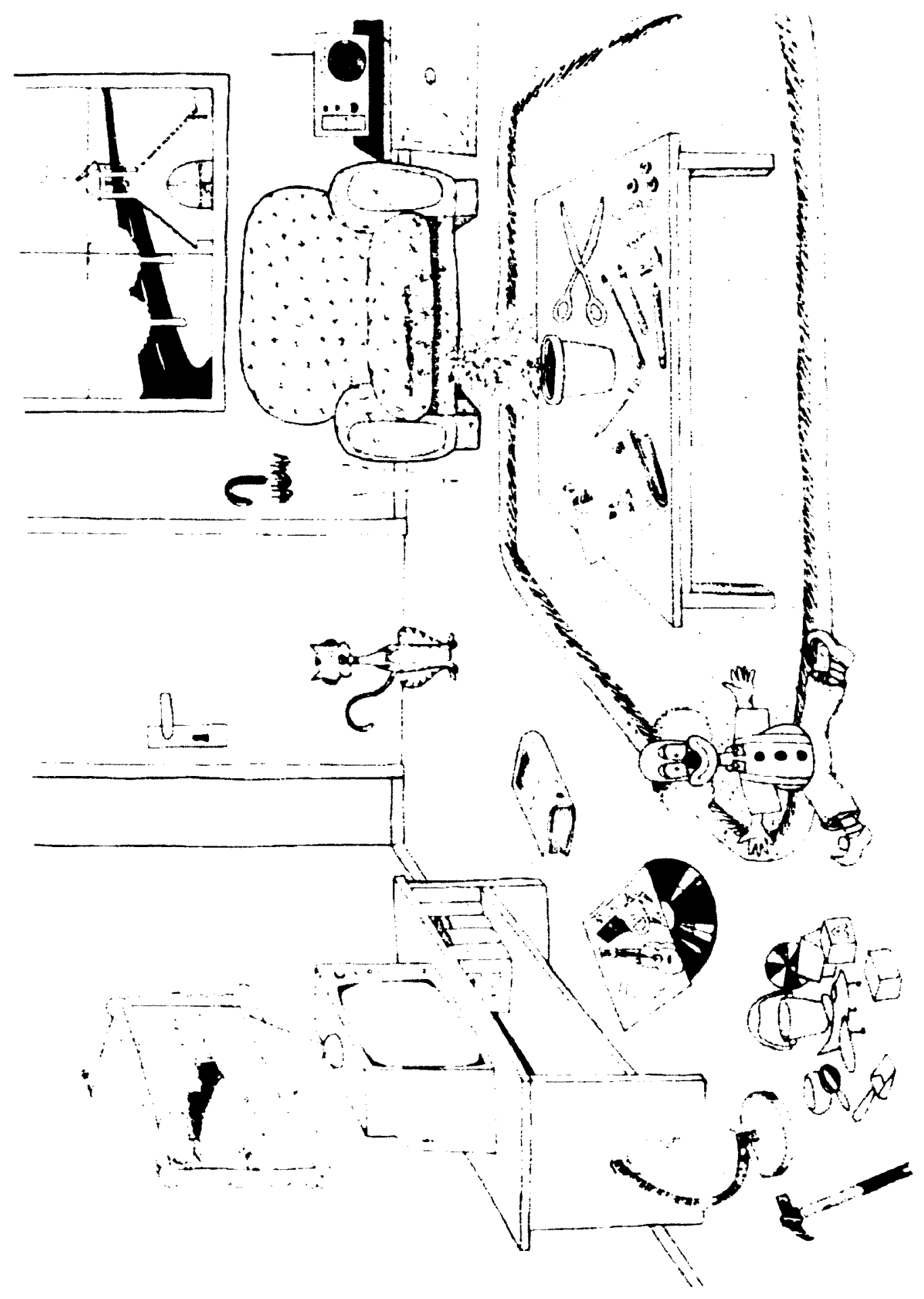




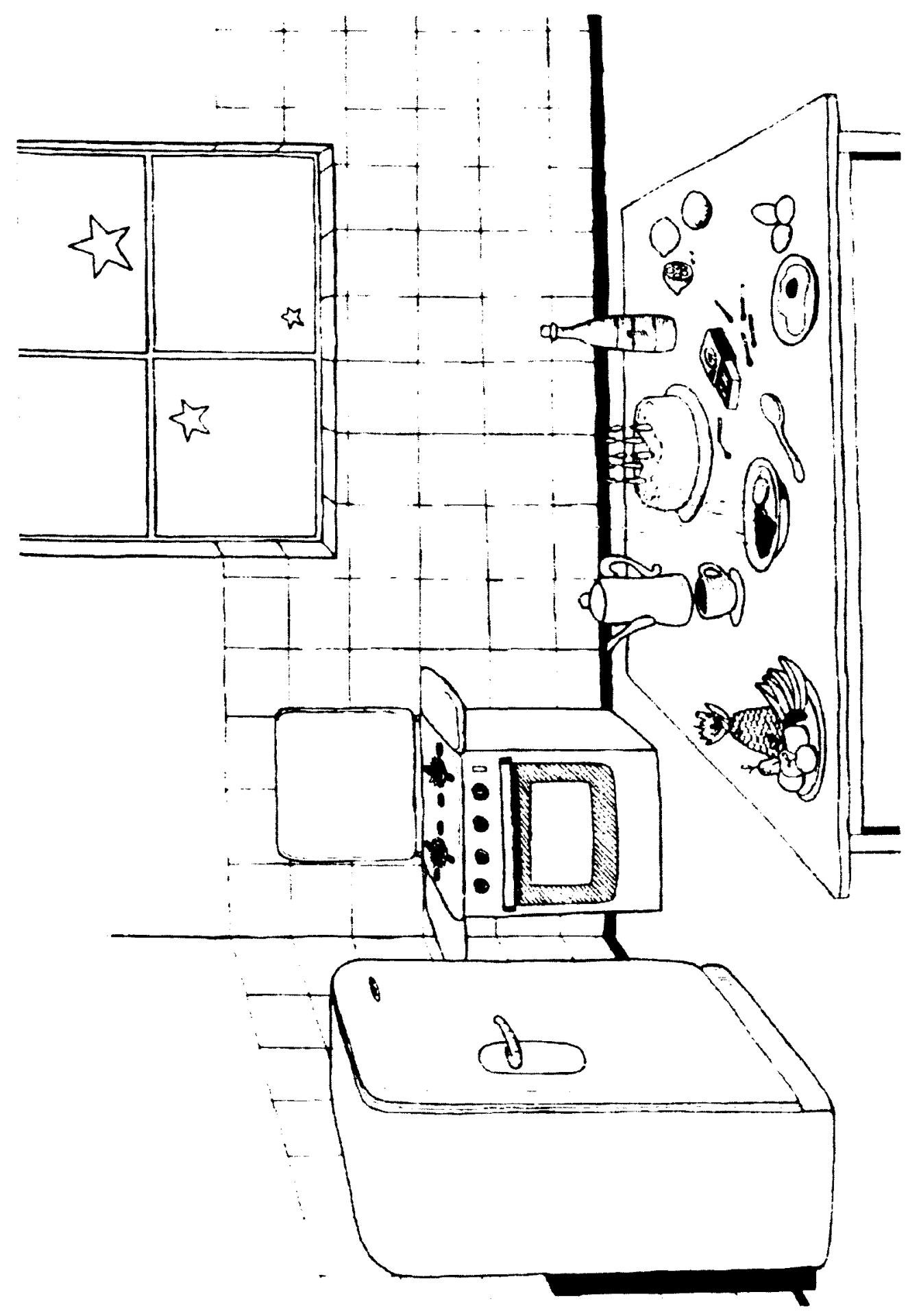




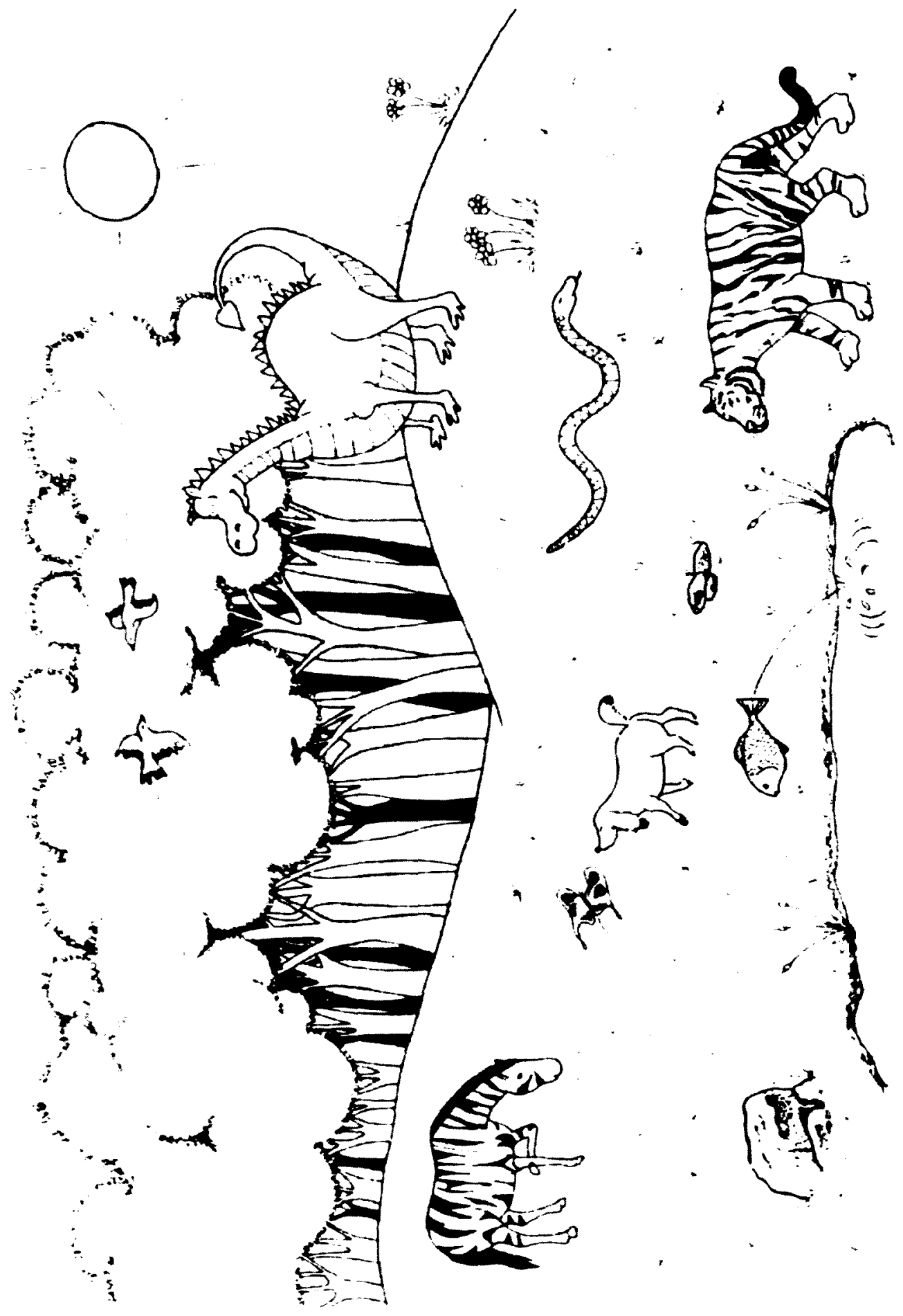




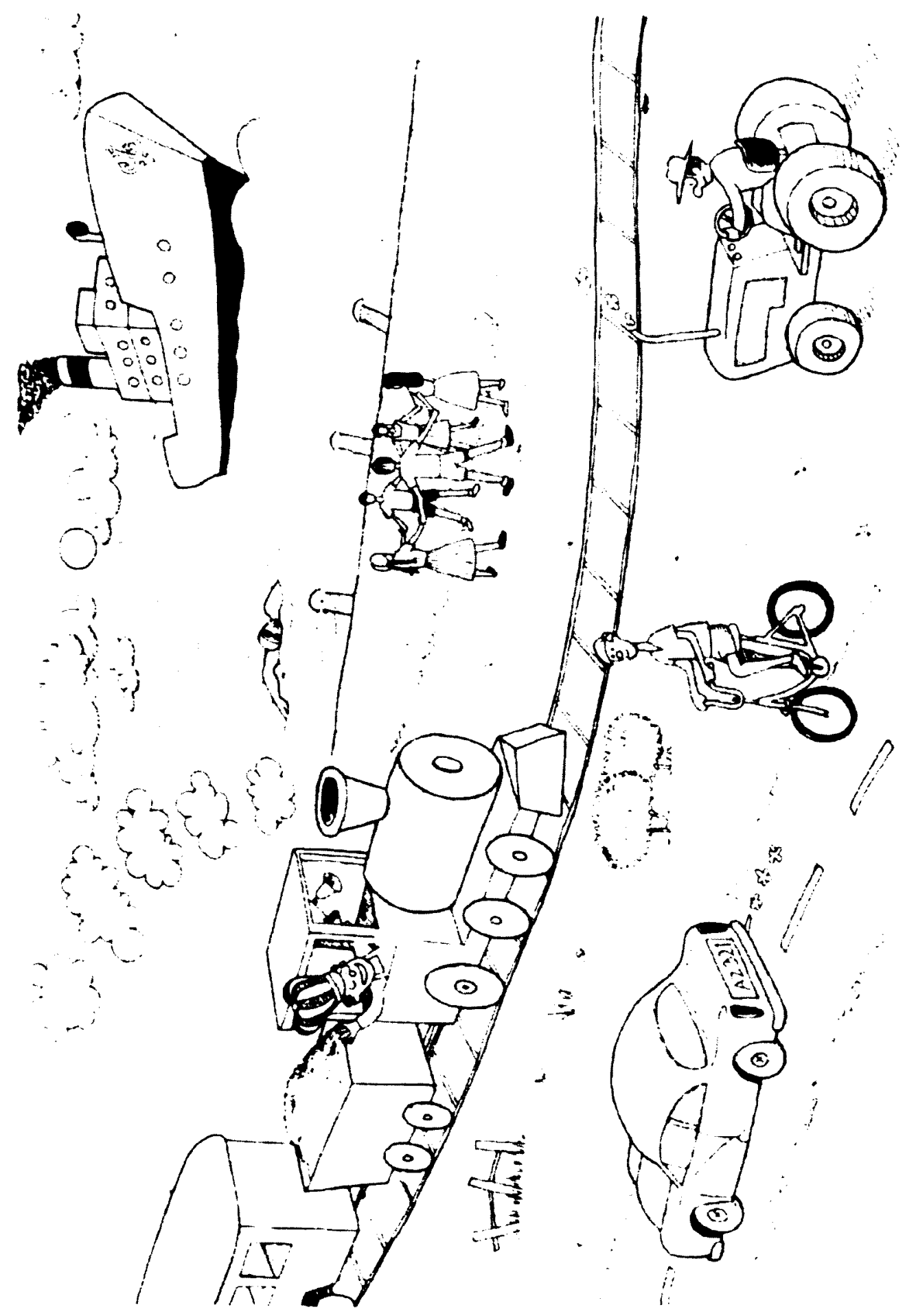




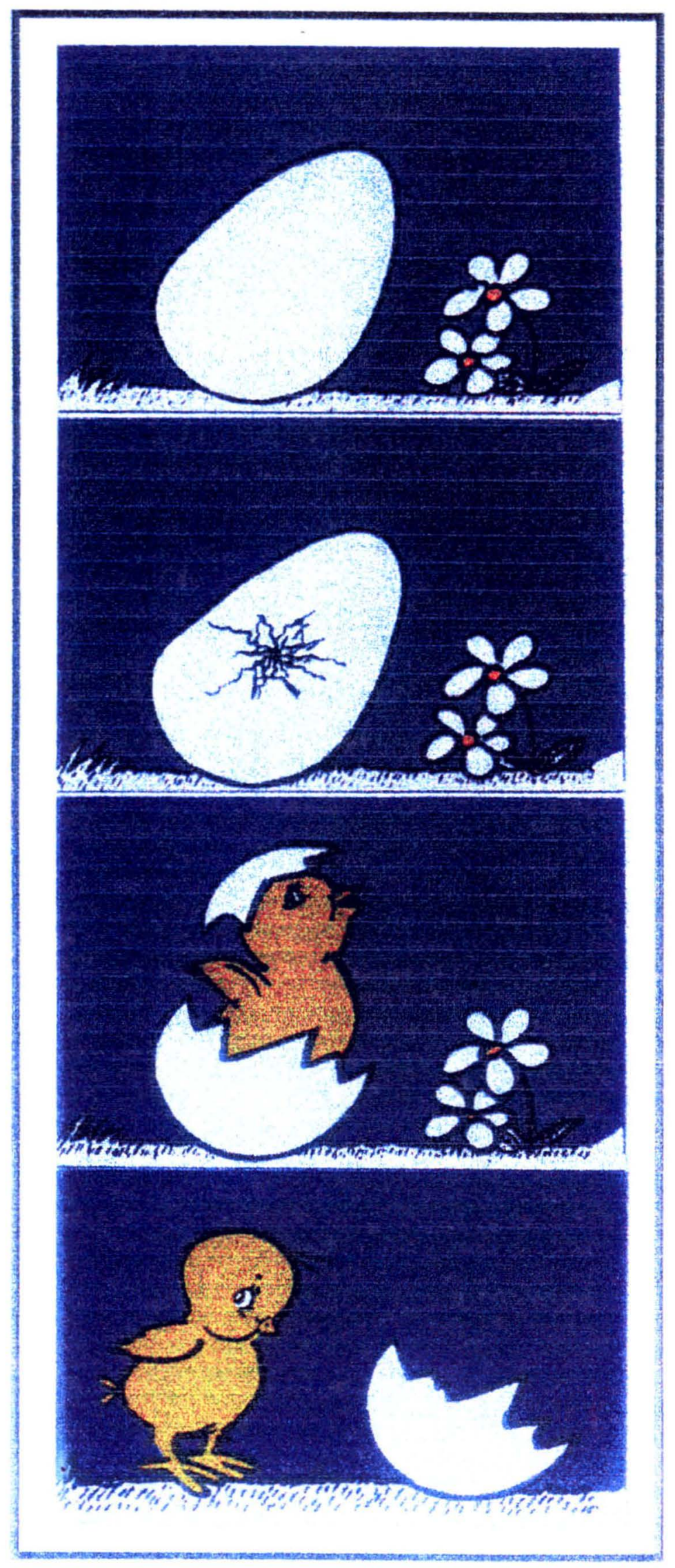


Anexo 11. Protocolo de registro dos achados da descrição da linguagem oral 
FICHA DE REGISTRO

DESCRIÇÃO DA LINGUAGEM ORAL

Sujeito:

Idade Grupo:

Data:

\section{Pontuação}

\begin{tabular}{|c|c|c|c|}
\hline & & $\begin{array}{c}\mathrm{N}^{\circ} \mathrm{de} \\
\text { achados } \mathrm{X} \\
\text { Valor do } \\
\text { aspecto }\end{array}$ & Pontos \\
\hline 1 & $\begin{array}{l}\text { Parte I - Formação de Conceitos } \\
\text { Tema 1 - Cor }\end{array}$ & & \\
\hline 2 & Tema 2 - Forma & & \\
\hline 3 & Tema 3 - Esquema Corporal & & \\
\hline 4 & Tema 4 - Posição no Espaço & & \\
\hline 5 & Tema 5 - Tamanho & & \\
\hline 6 & Tema 6 - Distância & & \\
\hline 7 & Tema 7 - Quantidade & & \\
\hline 8 & Tema 8 - Espessura & & \\
\hline 9 & Tema 9 - Altura & & \\
\hline 10 & Tema 10 - Comprimento & & \\
\hline 11 & Tema 11 - Igual/Diferente & & \\
\hline 12 & Tema 12 - Seqüência Lógico-Temporal & & \\
\hline & & \multicolumn{2}{|l|}{ Total P I } \\
\hline 13 & $\begin{array}{l}\text { Parte II - Desenvolvimento Fonêmico } \\
\text { Tema 13 - Descrição Fonêmica }\end{array}$ & & \\
\hline 14 & Tema 14 - Características da Fala & & \\
\hline & & \multicolumn{2}{|l|}{ Total P II } \\
\hline 15 & $\begin{array}{l}\text { Parte III - Narrativas Orais: } \\
\text { Tema } 15 \text { - Narrativas Orais } \\
\end{array}$ & & \\
\hline & & \multicolumn{2}{|l|}{ Total P III } \\
\hline
\end{tabular}

Obs: 
Anexo 12: Achados da Triagem Audiométrica e Imitanciométrica 


\section{Triagem Audiométrica e Imitanciométrica}

Quadro 1. Achados da Triagem Audiométrica e Imitanciométrica ${ }^{\dagger}$ realizada nas crianças dos grupos 6M e 4A do CADI 34 Jd Elisa Maria.

\begin{tabular}{|c|c|c|c|c|c|c|c|c|}
\hline Grupo & Crianças & Ouvido & Otoscopia & $\begin{array}{r}\text { Fre } \\
5001\end{array}$ & qüên & cia en & $\begin{array}{l}m \mathrm{mZ} \\
4000\end{array}$ & $\begin{array}{c}\text { Timpanometria } \\
\text { Curva }\end{array}$ \\
\hline $6 M$ & $\begin{array}{l}\text { WS } \\
\text { CRT } \\
\text { LOBG }^{2}\end{array}$ & $\begin{array}{l}O D \\
O E \\
O D \\
O E \\
O D \\
O E\end{array}$ & $\begin{array}{l}\text { normal } \\
\text { normal } \\
\text { normal } \\
\text { normal } \\
\text { normal } \\
\text { cerume }\end{array}$ & $\begin{array}{l}20 \\
20 \\
20 \\
20 \\
25 \\
40\end{array}$ & $\begin{array}{l}20 \\
20 \\
20 \\
20 \\
20 \\
40\end{array}$ & $\begin{array}{l}20 \\
20 \\
20 \\
20 \\
20 \\
25\end{array}$ & $\begin{array}{l}20 \\
20 \\
20 \\
25 \\
20 \\
20\end{array}$ & $\begin{array}{l}\text { Tipo A } \\
\text { Tipo A } \\
\text { Tipo A } \\
\text { Tipo A } \\
\text { Tipo A } \\
\text { Tipo C }\end{array}$ \\
\hline & $\begin{array}{l}\text { TSA } \\
\text { DLG } \\
\text { GS }\end{array}$ & $\begin{array}{l}\text { OD } \\
\text { OE } \\
O D \\
O E \\
O D \\
O E\end{array}$ & $\begin{array}{l}\text { normal } \\
\text { normal } \\
\text { normal } \\
\text { normal } \\
\text { normal } \\
\text { normal }\end{array}$ & $\begin{array}{l}20 \\
20 \\
20 \\
25 \\
20 \\
20\end{array}$ & $\begin{array}{l}20 \\
20 \\
20 \\
20 \\
20 \\
20\end{array}$ & $\begin{array}{l}20 \\
20 \\
20 \\
20 \\
20 \\
20\end{array}$ & $\begin{array}{l}20 \\
20 \\
20 \\
20 \\
20 \\
20\end{array}$ & $\begin{array}{l}\text { Tipo A } \\
\text { Tipo A } \\
\text { Tipo A } \\
\text { Tipo A } \\
\text { Tipo A } \\
\text { Tipo A }\end{array}$ \\
\hline $4 A$ & $\begin{array}{l}\text { JMP }^{3} \\
\text { KA } \\
\text { RJSJ } \\
\text { CMG } \\
\text { NO } \\
\text { TAML }\end{array}$ & $\begin{array}{l}\text { OD } \\
\text { OE } \\
\text { OD } \\
O E \\
O D \\
O E \\
O D \\
O E \\
O D \\
O E \\
O D \\
O E\end{array}$ & $\begin{array}{l}\text { normal } \\
\text { cerume } \\
\text { normal } \\
\text { normal } \\
\text { normal } \\
\text { normal } \\
\text { normal } \\
\text { normal } \\
\text { normal } \\
\text { normal } \\
\text { normal } \\
\text { normal }\end{array}$ & $\begin{array}{l}20 \\
40 \\
20 \\
20 \\
20 \\
20 \\
20 \\
20 \\
20 \\
20 \\
20 \\
20\end{array}$ & $\begin{array}{l}20 \\
25 \\
20 \\
20 \\
20 \\
20 \\
20 \\
20 \\
20 \\
20 \\
20 \\
20\end{array}$ & $\begin{array}{l}20 \\
25 \\
20 \\
20 \\
20 \\
20 \\
20 \\
20 \\
20 \\
20 \\
20 \\
20\end{array}$ & $\begin{array}{l}20 \\
20 \\
20 \\
20 \\
20 \\
20 \\
20 \\
20 \\
20 \\
20 \\
20 \\
20\end{array}$ & $\begin{array}{l}\text { Tipo A } \\
\text { Tipo C } \\
\text { Tipo A } \\
\text { Tipo A } \\
\text { Tipo A } \\
\text { Tipo A } \\
\text { Tipo A } \\
\text { Tipo A } \\
\text { Tipo A } \\
\text { Tipo A } \\
\text { Tipo A } \\
\text { Tipo A }\end{array}$ \\
\hline
\end{tabular}

${ }^{1}$ Realizada com os aparelhos portáteis AUDIOSCOPE ${ }^{\mathrm{tm}}$ e MICROTYMP' ${ }^{\mathrm{tm}}$ da Welch Allyn ${ }^{\text {ia }}$. ${ }^{2}$ Criança encaminhada para a avaliação otorrinolaringológica para a retirada de rolha de cerume apresentada à otoscopia e posteriormente realização da Avaliação Audiológica. ${ }^{3}$ Criança encaminhada para a avaliação otorrinolaringológica para a retirada da rolha de cerume apresentada à otoscopia e posteriormente realização da Avaliação Audiológica. 
Anexo 13: Desempenho das crianças submetidas à descrição da linguagem 
Tabela 6 - Desempenho das crianças submetidas à descriçăo da linguagem, Såo Paulo, 1999.

\begin{tabular}{|c|c|c|c|c|c|c|c|c|c|c|c|c|c|c|c|c|c|c|c|c|}
\hline SUJEITOS & TEMPO & COR & FORMA & EC $^{1}$ & ESP ${ }^{2}$ & TAM $^{3}$ & DIST * & QUAN $^{5}$ & ESPE ${ }^{*}$ & ALT ${ }^{7}$ & COM & $10^{\circ}$ & SLT ${ }^{10}$ & PEI" & $\mathrm{DF}^{12}$ & $C^{13}$ & PEII ${ }^{14}$ & No ${ }^{15}$ & PEIII ${ }^{10}$ & PT ${ }^{17}$ \\
\hline ws & $6 M$ & 1,76 & 1,50 & 1,62 & 1,80 & $2, \infty 0$ & $2, \infty 0$ & $2, \infty$ & 2,00 & $2, \infty$ & $2, \infty 0$ & $2, \infty$ & $2, \infty 0$ & 22,68 & 6,42 & 6,42 & 12,84 & 21,60 & 21,60 & 57,12 \\
\hline CRT & $6 \mathrm{M}$ & 0,00 & $0, \infty 0$ & 1,35 & 1,50 & 1,20 & $0, \infty$ & 0,00 & 0,00 & $2, \infty$ & $0, \infty 0$ & $1, \infty$ & $0, \infty$ & 7,05 & 4,28 & 2,14 & 6,42 & 10,80 & 10,80 & 24,27 \\
\hline LOBG & $6 M$ & 0,22 & 0,00 & 1,44 & 0,60 & 1,20 & $0, \infty$ & 0,00 & $0, \infty 0$ & $2, \infty$ & $0, \infty$ & $1, \infty$ & $0, \infty$ & 6.46 & 4,28 & 8,56 & 12,84 & 18,90 & 18,90 & 38,20 \\
\hline TSA & $6 \mathrm{M}$ & 0,66 & $1, \infty 0$ & 1,62 & 1,20 & $2, \infty 0$ & $2, \infty 0$ & 2,00 & 2,00 & $2, \infty 0$ & $0, \infty$ & 0,00 & $1, \infty$ & 15,48 & 8,56 & 8,56 & 17,12 & 35,10 & 35,10 & 75,80 \\
\hline GS & $6 M$ & 0,88 & $2, \infty 0$ & 1,62 & 0,60 & 0,60 & $2, \infty 0$ & 0,00 & 2.00 & 2,00 & 2,00 & 2,00 & $1, \infty$ & 18,10 & 8.56 & 8.56 & 17,12 & 35.10 & 35,10 & 70,32 \\
\hline DLG & $6 M$ & 0,44 & 0.50 & 1,44 & 1,20 & 1,20 & 1,60 & $1, \infty$ & $2, \infty 0$ & $2, \infty 0$ & $2, \infty$ & 0,00 & $0, \infty$ & 12,18 & 6,42 & 8,56 & 14,98 & 10,80 & 10,80 & 37,96 \\
\hline JMP & $4 A$ & $2, \infty 0$ & 1,50 & 1,71 & 1,80 & 2,00 & $2, \infty 0$ & $2, \infty$ & $2, \infty$ & $2, \infty 0$ & $0, \infty$ & $1, \infty$ & $1, \infty$ & 19,01 & $15, \infty 0$ & 15,00 & 30,00 & 35,10 & 35,10 & 84.11 \\
\hline$K A$ & $4 A$ & 1.54 & 1,50 & 1.71 & 1,20 & $2, \infty 0$ & 2,00 & $2, \infty 0$ & $2, \infty 0$ & 2,00 & $2, \infty$ & $2, \infty 0$ & $1, \infty$ & 20,95 & 15,00 & 15,00 & $30, \infty$ & 46,00 & 46,00 & 96,96 \\
\hline RJSJ & $4 A$ & 1,54 & $1, \infty$ & 1,80 & 1,80 & $2, \infty 0$ & $0, \infty$ & $2, \infty 0$ & $2, \infty 0$ & $2, \infty 0$ & $0, \infty$ & $1, \infty$ & $2, \infty 0$ & 17,14 & 15,00 & $15, \infty 0$ & $30, \infty$ & 40,50 & 40,45 & 87,64 \\
\hline CMG & $4 A$ & 0,66 & 1,50 & 1,80 & 1,80 & 1,60 & 2,00 & $2, \infty 0$ & $2, \infty 0$ & 2,00 & $2, \infty$ & $2, \infty 0$ & 2,00 & 21,36 & 10,70 & 10,70 & 21.40 & 43,20 & 43,20 & 85,96 \\
\hline TAML & 44 & 1,76 & 1,50 & 1,71 & $2, \infty 0$ & $2, \infty 0$ & $2, \infty 0$ & $2, \infty 0$ & $2, \infty 0$ & $2, \infty$ & $2, \infty$ & $2, \infty 0$ & $2, \infty 0$ & 22,97 & 12,84 & 15,00 & 27,84 & 32,40 & 32,40 & 83,21 \\
\hline No & $4 A$ & $2, \infty 0$ & 1,50 & 1,71 & 2.00 & $2, \infty$ & 2,00 & 2,00 & 2,00 & 2,00 & $2, \infty$ & 2,00 & $1, \infty$ & 22,21 & 10,70 & 12,84 & 23,54 & 43,20 & 43,20 & 88,96 \\
\hline
\end{tabular}

: EC: esquema corporal (identificaçăo das partes do corpo)

: ESP espaço

TAM tamanho

DIST: distância

QUAN: quantidade

ESPE: espessura

ALT: altura

\& COM: comprimento

10 SLT: sequééncia lógico-temporal

11 PEl: pontuaçáo especifica para o item formulaçăo de conceitos

12 DF: descriçăo fonética

${ }^{13}$ CF: caracteristicas de produção da fala

is PEIl: pontuaçăo especifica para o item produçăo oral

is NO: narrativas orais

10 PEIII: pontuaçăo especifica para o item produçăo de narrativas orais

17 PT: pontuaçăo total (variça de $0-100)$ 
Tabela 7 - Pontuaçăo específica de cada variável no grupo de crianças de 6m, Săo Paulo, 1999.

\begin{tabular}{|c|c|c|c|c|c|c|c|c|c|c|c|c|c|c|c|}
\hline SUJEITOS & COR & FORMA & $E C^{\prime}$ & ESP $^{2}$ & TAM $^{3}$ & DIST $^{4}$ & QUAN 5 & ESPE" & ALT ${ }^{\prime}$ & $\operatorname{com}^{\prime}$ & $10^{\circ}$ & SLT ${ }^{10}$ & DF ${ }^{11}$ & $\mathrm{CF}^{12}$ & $\mathrm{NO}^{13}$ \\
\hline WS & 1,76 & 1,50 & 1,62 & 1,80 & 2,00 & 2,00 & 2,00 & 2,00 & 2,00 & 2,00 & 2,00 & 2,00 & 6.42 & 6,42 & 21,60 \\
\hline CRT & 0,00 & 0,00 & 1,35 & 1.50 & 1,20 & 0,00 & 0,00 & 0,00 & 2,00 & 0,00 & 1,00 & 0,00 & 4,28 & 2,14 & 10,80 \\
\hline LOBG & 0,22 & 0,00 & 1,44 & 0,60 & 1,20 & 0,00 & 0,00 & 0,00 & 2,00 & 0,00 & 1,00 & 0,00 & 4,28 & 8,56 & 18,90 \\
\hline TSA & 0,66 & 1,00 & 1,62 & 1,20 & 2,00 & 2,00 & 2,00 & 2,00 & 2,00 & 0,00 & 0,00 & 1,00 & 8.56 & 8,56 & 43,20 \\
\hline GS & 0,88 & 2,00 & 1,62 & 0,60 & 0,60 & 2,00 & 0,00 & 2,00 & 2,00 & 2,00 & 2,00 & 1,00 & 8,56 & 8,56 & 35,10 \\
\hline DLG & 0,44 & 0,50 & 1,44 & 1,20 & 1,20 & 1,60 & 1,00 & 2,00 & 2,00 & 2,00 & 0,00 & 0,00 & 6,42 & 8,56 & 10,80 \\
\hline Pontos & 3,96 & 5,00 & 9,09 & 6,90 & 8,20 & 7,60 & 5,00 & 8,00 & 12,00 & 6,00 & 6,00 & 4,00 & 38,52 & 42,80 & 140,40 \\
\hline
\end{tabular}

EC: esquema corporal (identificaçăo das partes do corpo)

ESP : espaço

- TAM: tamanho

DIST: distância

QUAN: quantidade

ESPE: espessura

7 ALT: altura

COM: comprimento

ID: igual-diferente

SLT: sequuéncia lógico-temporal

1 DF: descriçăo fonética

CF: caracteristicas de fala

${ }^{3}$ NO: narrativas orais 
Tabela 8 - Pontuaçăo especifica de cada variável no grupo de crianças de 4m, São Paulo, 1999.

\begin{tabular}{|c|c|c|c|c|c|c|c|c|c|c|c|c|c|c|c|}
\hline SUJEITOS & COR & FORMA & $\mathrm{EC}^{\prime}$ & ESP $^{2}$ & TAM $^{3}$ & DIST ${ }^{4}$ & QUAN 5 & ESPE ${ }^{\circ}$ & ALT $^{7}$ & $\mathrm{COM}^{\circ}$ & $10^{\circ}$ & SLT ${ }^{10}$ & DF ${ }^{\prime \prime}$ & $C F^{12}$ & NO $^{13}$ \\
\hline JMP & 2,00 & 1,50 & 1,71 & 1,80 & 2,00 & 2,00 & 2,00 & 2,00 & 2,00 & 0,00 & 1,00 & 1,00 & 15,00 & 30,00 & 35,10 \\
\hline$K A$ & 1,54 & 1,50 & 1,71 & 1.20 & 2,00 & 2,00 & 2,00 & 2,00 & 2,00 & 2,00 & 2,00 & 1,00 & 15,00 & 30,00 & 46,00 \\
\hline RJSJ & 1,54 & 1,00 & 1,80 & 1,80 & 2,00 & 0,00 & 2,00 & 2,00 & 2,00 & 0,00 & 1,00 & 2,00 & 15,00 & 30,00 & 40,50 \\
\hline CMG & 0,66 & 1,50 & 1,80 & 1.80 & 1,60 & 2,00 & 2,00 & 2,00 & 2,00 & 2,00 & 2,00 & 2,00 & 10,70 & 21,40 & 43,20 \\
\hline TAML & 1,76 & 1,50 & 1,71 & 2,00 & 2,00 & 2,00 & 2,00 & 2,00 & 2,00 & 2,00 & 2,00 & 2,00 & 15,00 & 27,84 & 32,40 \\
\hline NO & 2,00 & 1,50 & 1,71 & 2,00 & 2,00 & 2,00 & 2,00 & 2,00 & 2,00 & 2,00 & 2,00 & 1,00 & 12,84 & 23,54 & 43,20 \\
\hline Pontos & 9,50 & 8,50 & 10,44 & 10,60 & 11,60 & 10,00 & 10,00 & 10,00 & 10,00 & 8,00 & 10,00 & 9,00 & 83,54 & 162,78 & 240,40 \\
\hline
\end{tabular}

' EC: esquema corporal (identificaçăo das partes do corpo)

ESP : espaço

DIST: distância

5 QUAN quantidade

ESPE espessura

ALT: altura

- COM comprimento

- ID igual-diferente

${ }^{10}$ SLT sequéncia lógico-lemporal

11 DF. sequéncia lógico-fem

12 CF: caracteristicas de fala

i3 NO narrativas orais 


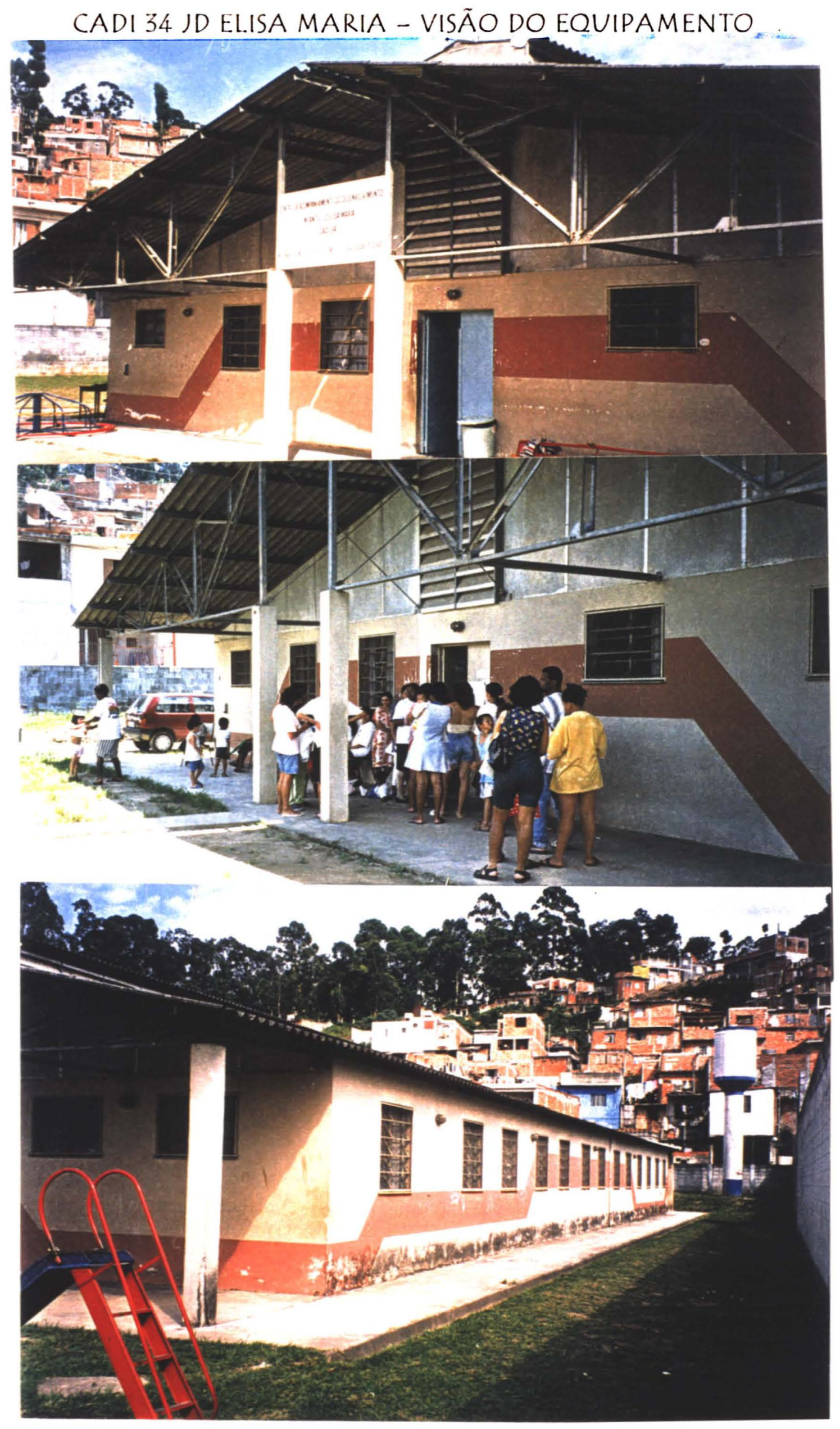

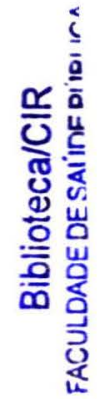




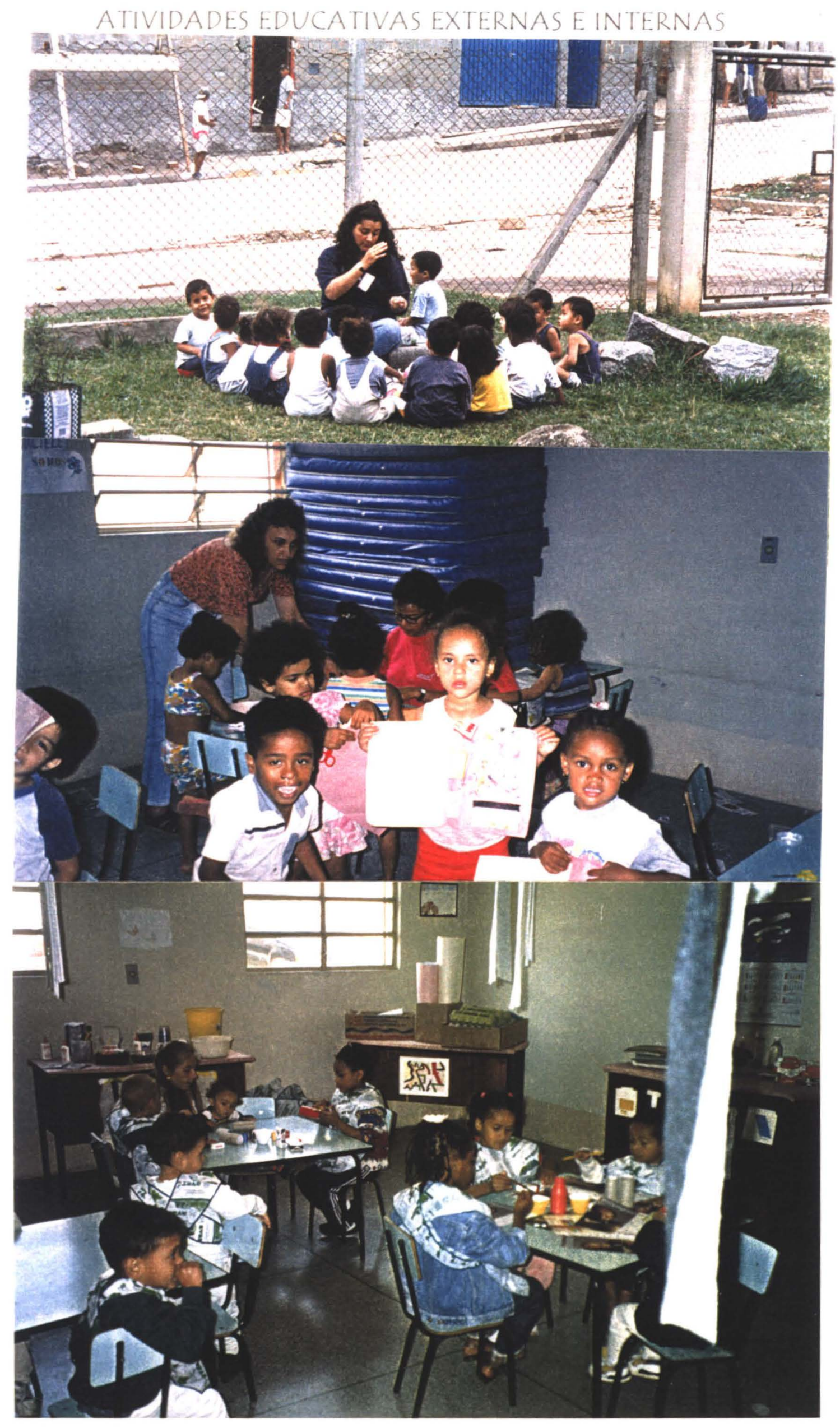


ATIVIDADES DE RECREACÃO

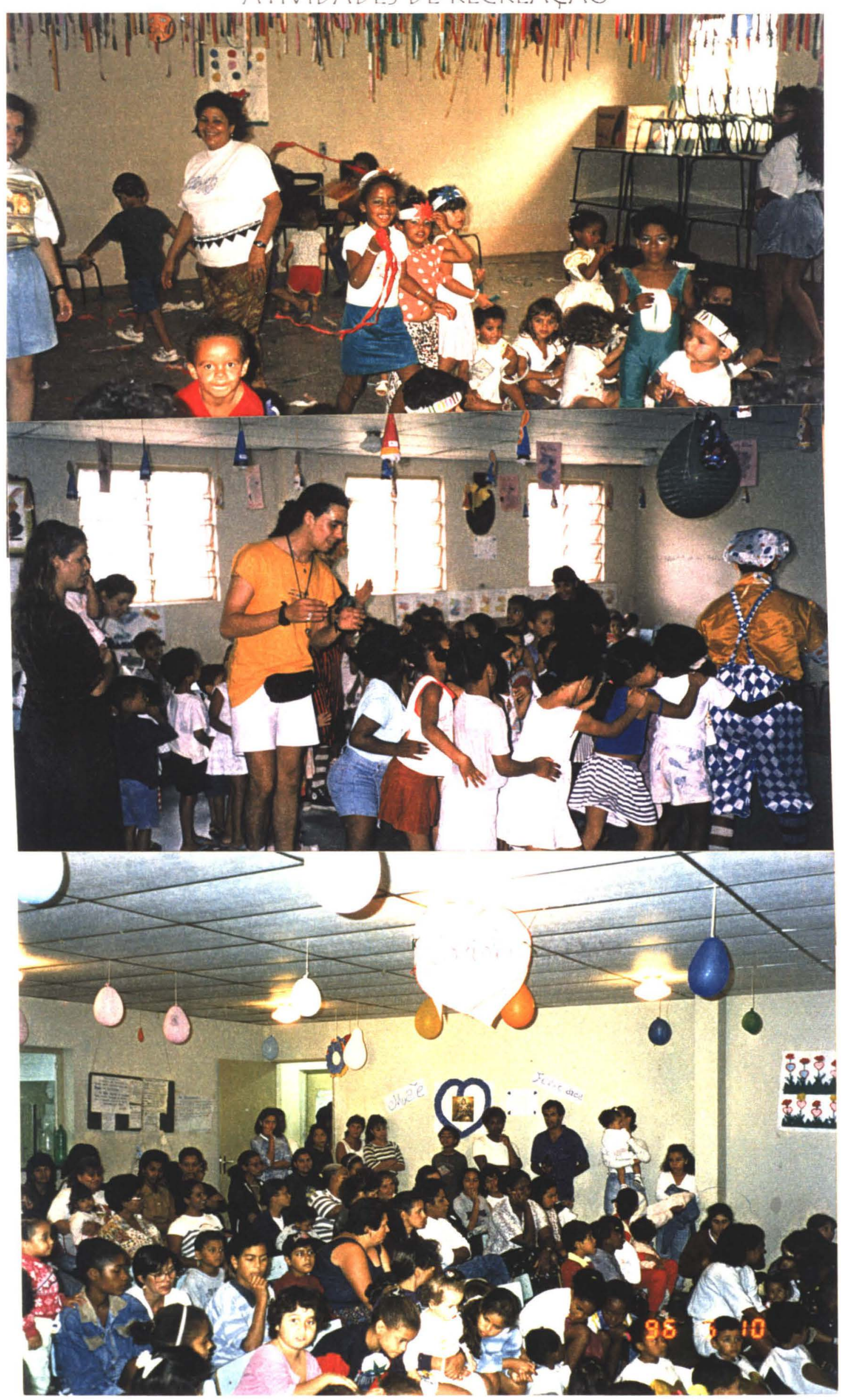


ATIVIDADES SOCIO-CULTURAIS



